Universidade de São Paulo

Faculdade de Educação

Programa de Pós-Graduação em Educação

Educação e Ciências Sociais: Desigualdades e Diferenças

Marcos Antônio de Oliveira

\title{
INDÍGENAS E ENSINO MÉDIO EM RORAIMA DEMANDAS DE ESTUDANTES MACUXI
}


Marcos Antônio de Oliveira

\title{
INDÍGENAS E ENSINO MÉDIO EM RORAIMA: DEMANDAS DE ESTUDANTES MACUXI
}

\author{
Versão corrigida
}

Tese apresentada ao Programa de Pós-Graduação em Educação da Faculdade de Educação da Universidade de São Paulo como exigência parcial para a obtenção do título de Doutor em Educação

Área de concentração:

Educação e Ciências Sociais: Desigualdades e Diferenças

Orientador:

Prof. Dr. Elie George Guimarães Ghanem Jr. 
Autorizo a reprodução e divulgação total ou parcial deste trabalho, por qualquer meio convencional ou eletrônico, para fins de estudo e pesquisa, desde que citada a fonte. 
Nome: OLIVEIRA, Marcos Antônio de

Título: Indígenas e ensino médio em Roraima: demandas de estudantes macuxi

Tese apresentada à Faculdade de Educação da Universidade de São Paulo para obtenção do título de Doutor em Educação.

Aprovado em:

Banca Examinadora

Prof. ${ }^{a}$ Dra.

Instituição:

Julgamento:

Prof. Dra.

Instituição:

Julgamento:

Prof. Dr.

Instituição:

Julgamento:

Prof. ${ }^{a}$ Dra.

Instituição:

Julgamento: 


\section{AGRADECIMENTOS}

Agradecer sempre é importante, pois não conseguimos realizar nada do porte de uma pesquisa de doutorado sem a ajuda de muitas pessoas. Foi fundamental o auxílio institucional fornecido pelo Instituto Federal de Roraima, nas pessoas do diretor-geral do Câmpus Amajari, George Sterfson, e da reitora Sandra Mara de Paula Dias Botelho, que concederam meu afastamento para realizar a pesquisa. Agradeço também a bolsa do programa Prodoutoral fornecida pela Capes por meio da Pró-Reitoria de Ensino e Pesquisa do IFRR.

Inúmeras pessoas concederam entrevistas de forma prestativa e amigável. Lideranças indígenas das comunidades Três Corações, Aningal, Guariba, Barro, Contão. Gestores das escolas estaduais indígenas Santa Luzia, José Marcolino, Tuxaua Silvestre Messias e Tuxaua Manoel Horácio, e alguns alunos e alunas macuxi dessas instituições. Também agradeço aos servidores docentes do Caes, em especial ao Francisco Moura e ao Rafael Régis; às servidoras do Cores Enny e Marcela, e aos da gestão: a diretora de ensino Pierângela Cunha, a pedagoga Luana Lobo, os coordenadores de curso Marcelo Pontes, Rafael Barros e Daniel Rodrigues. E a amigos e amigas como José Vilson, Alessandro, Lucas Lima, Alessandra e Elisângela, e outros e outras que já não estão mais no CAM e no entanto me ajudaram com um apoio, abraço e incentivo.

Aos alunos e alunas do CAM, que me atenderam cedendo seu tempo, falando de si e me ajudando a admirá-los e admirá-las mais do que antes.

Ao professor e antropólogo Maxim Repetto, que generosamente compartilhou ideias e material particular, e sugeriu parcerias para tornar mais feliz a vida dos e das estudantes indígenas. À professora Roseli Bernardo, do Câmpus Boa Vista, que conversou sobre o programa Saberes Indígenas.

A escrita de uma tese é solitária e em alguns momentos angustiante, por não sabermos que caminhos estamos tomando e aonde nos levarão. No entanto, algumas pessoas são muito importantes para ajudar a tornar esse trajeto mais orientado e satisfatório.

Agradeço ao meu orientador, que sempre me atendeu nessas angústias e, com seu cuidado e profissionalismo, me deu o norte necessário. Também agradeço aos professores e professoras da pós-graduação, em especial Lilia Schwarcz (FFLCH-USP), Fabiana Jardim (Feusp) e Ana Paula Cavalcanti Simioni (IEB-USP). As sugestões e considerações da professora Clarice Cohn e do professor Paulo Santilli na qualificação foram de fundamental importância. 
De forma muito singela agradeço as sugestões e reflexões produzidas na defesa da tese pelas Prof. ${ }^{\text {as }}$ Dr. ${ }^{\text {as }}$ Marina Vanzolini, Marta Azevedo e Aline Abonizzio, acompanhadas das contribuições do Prof. Dr. Maxim Repetto, que enriqueceram e apontaram muitas sugestões para a redação final da tese.

Agradeço à minha família que, mesmo sem entender muito o que estava acontecendo, sempre me apoiou. Irmão, irmãs e minha querida mãe. Aos amigos que sempre perguntavam sobre a pesquisa e me permitiam falar um pouco sobre o tema.

Impossível seria passar por esse momento sem o apoio, paciência e carinho de minha esposa Isabel. Ouvinte atenta das minhas elaborações e dúvidas referentes à pesquisa e comentarista essencial dos meus escritos. Sempre presente para conter o desejo de meu querido filho Eduardo de estar comigo quando não podia. Aos meus filhos Eduardo e Gabriel, que me alegravam com suas presenças quando a insatisfação da escrita não ia embora. 


\section{RESUMO}

OLIVEIRA, M. A. Indígenas e ensino médio em Roraima: demandas de estudantes Macuxi. 2020. Tese (Doutorado em Educação) - Faculdade de Educação, Universidade de São Paulo, São Paulo, 2020. 164 p.

Esta tese expõe uma pesquisa dedicada a dois objetivos centrais: 1) entender as motivações que atraem estudantes macuxi ao Câmpus Amajari (CAM) do Instituto Federal de Roraima, para cursarem ensino médio técnico profissionalizante em Agropecuária e Aquicultura em regime integrado e de alternância; 2) descobrir o que buscam nessa instituição. Os/as estudantes que participaram da pesquisa vieram de comunidades que estão, em média, a $150 \mathrm{~km}$ do CAM, enfrentando muitas dificuldades para seguir e concluir o curso, mesmo dispondo de escolas de ensino médio indígenas em suas comunidades. A pesquisa identificou as expectativas dos/as estudantes sobre sua permanência na instituição, bem como suas impressões sobre suas comunidades e sobre as opções de escolarização disponíveis. Para tanto, optou-se pela observação participante e por entrevistas detalhadas com 22 estudantes da instituição e 11 estudantes de escolas indígenas das comunidades Três Corações, Guariba e do Barro, além de conversas com gestores, docentes e lideranças indígenas da região. As hipóteses tratadas com as informações empíricas foram: 1) os motivos que traziam esses/as estudantes respondiam ao desejo de familiares, de amigos/as e de lideranças de que os/as jovens retornassem às suas comunidades para auxiliar em futuros projetos agropecuários ou de piscicultura, sendo que os/as estudantes também tinham outros objetivos decorrentes de sua experiência no CAM, que poderiam não coincidir com o desejo de seus/suas responsáveis; 2) o que buscam na instituição estaria relacionado majoritariamente à perspectiva de ingressarem nas universidades públicas e privadas do estado, por considerarem a escolarização do CAM mais apropriada para esse objetivo em oposição às dificuldades que as escolas indígenas apresentam. A hipótese referente aos motivos que atraem os/as jovens macuxi ao CAM se mostrou verdadeira, pois foi constatado que estão inicialmente condicionados/as às decisões de seus/suas responsáveis e, da mesma forma, evidenciou-se que, no decorrer da formação e do ambiente escolar, a maioria é impulsionada a prosseguir em seus estudos. A hipótese sobre o que buscam na instituição também se confirmou, tendo-se explicitado o ensino superior como um projeto de futuro desses/as estudantes do CAM.

Palavras-chave: Educação escolar indígena. Macuxi. Ensino médio. IFRR-Roraima. 


\begin{abstract}
OLIVEIRA, M. A. Indigenous People and High School Education in Roraima, Brazil: Demands from Macuxi Students. 2020. Doctoral thesis (Education) - Faculdade de Educação, Universidade de São Paulo, São Paulo (Brazil), 2020. 164 p.

This thesis expounds a research with two main goals, which are 1) to understand the motivations that attract Macuxi students to the Amajari Campus (CAM) of the Federal Institute of Education in Roraima, Brazil, in order to attend technical vocational high school education in Agriculture and Aquaculture, in a full-time, seasonal ("de alternância") regime; 2) to find out what they are looking for in attending this educational institute. The students who participated in the research come from communities that are, on average, $150 \mathrm{~km}$ away from the campus, facing many difficulties to study and graduate there, even though they have indigenous high schools in their communities. The research identified the students' expectations about their stay at the institution, as well as their impressions about their communities and about the schooling options available. To this end, we resorted to participant observation and did detailed interviews with 22 students from the institution and 11 students from indigenous schools in the communities of Três Corações, Guariba and Barro, in addition to conversations with public managers, teachers, and indigenous leaders in the region. The hypotheses to be confronted with the empirical information were that: 1) the reasons that brought these students to the CAM responded to the desires of family members, friends and leaders, who wish that young people return to their communities to assist in agricultural, livestock or pisciculture projects, while the students also had other objectives arising from their experience at CAM, which might not coincide with the wishes of their elders; 2) what they look for in the institution would be mostly related to the prospect of entering public and private universities in the state, as they consider the education they get at CAM more appropriate for this purpose, in opposition to the hindrances encountered in indigenous schools. The hypothesis regarding the reasons that attract young Macuxi to CAM was confirmed, as it was found that they are initially conditioned to the decisions of their elders, and as it became likewise evident that, throughout the training and living in the school environment, most are encouraged to continue their studies. The hypothesis about what they are looking for in the institution was also confirmed, with higher education being made explicit as a project these CAM students have for the future.
\end{abstract}

Keywords: Indigenous school education. Macuxi. High school education. IFRR-Roraima. 


\section{MARARON*}

OLIVEIRA, M. A. Indígenas e ensino médio em Roraima: demandas de estudantes Macuxi. 2020. Tese (Doutorado em Educação) - Faculdade de Educação, Universidade de São Paulo, São Paulo, 2020. 164 p.

Seni' imenukaasa' wanî asaakî'ne ineeporîiton: 1) u'wani' awanî yenen makuusiyamî' teesenupasaanon iipî mîrîrî Amajari pona' esenupai', î'kai'ma o'ma'kon tuwarî'ka'to' pî' esenupai' moroopai î'kai'ma umî pî esenyaka'manto' yeseru pî esenupai', esenupano' kaisîrî iku'sa'pî'; 2) Î' yera'mai' to' i'sa' tîserukon ton. Aminke poi iipî'san eesenupasanon, teuren, tipaatakon po esenupanto' wanî taane, tî̂se u'wani' awanî yenen to' i'sa'. Inna, to' esereke tiyanporon esenupanto' wanî yenen, tîwaakîrikon pe era'masa' toya. Mîrîrî to'pe, to' pî' esenyawanto' ya tiwin pemonkon asaakî'ne ipona' teesenyawasonon yekaranmapo'pî moroopai miya' tamî'nawîrî tiwin ipona' tesenyawaasonon Eseurîwî'ne Tewankon ponkon, Arautaimî'ta wonkon moroopai Nonporimî ponkon, mîrîrî tîîse, tiyaronkon esenupanto'kon pî' teesenyaka'masan, to' yepootorî, teesenupasanon narî yekaranmapo'pî mîrîrîkon pî̀'. Amennanpe epu'tîton wanî sewarantî: 1) Iipî'san esenupai' wanî mîrîrî tiyunkon moroopai tonpakon pîkînsa. Moro teesenupai' to' enna'poto'pe kai'ma tipaatakn ya' tonpakon yenuupai', î'kai'ma to' yekînnan tuwarî'ka to' moroopai î'kai'ma umî koneekato' yekarepî̀ to' yenuupai'. 2) Innî' panpî' teesenupasanon esenupaato'pe, ipîkku esenupanto' pata'se' ya', maasa pra esenupanto' moro Amajaripo wanî itu'se e'nîto' kaisarî awanî yenen. Innarî, inkamoro iipî'san Amajari pona' senupai' wanî tiyunkon, tipootorîikon, tonpakon wenai, moroopai innî' panpî' esenupapai to' wanî, nnî' panpî epu'nen pe tuwanîkonpa.

Mai ipîkkukon: Patamunayamî esenupaato'. Makuusiyamî'. Esenupanto' rakkita pairon. IFRRRoraimî.

\footnotetext{
* Em língua macuxi. Tradução realizada pelo Professor Celino Raposo.
} 


\section{LISTA DE ILUSTRAÇÕES}

Figura $1 \quad$ Mapa dos campi do IFRR no estado de Roraima

p. 15

Figura 2 Mapa das terras indígenas demarcadas no Estado de Roraima

p. 15

Figura 3 Vista área da Vila Brasil, distrito-sede do município de Amajari

p. 16

Figura 4

Câmpus Amajari do IFRR

p. 17

Figura 5

Gráfico: Etnias presentes no Câmpus Amajari em 2017

p. 18

Figura 6 Gráfico: Causas da evasão e retenção no CAM em 2013

p. 19

Figura 7

Alunos/as do CAM nas comemorações da semana dos povos indígenas em 2019

p. 26

Figura 8

Fachada da Escola Estadual Indígena Santa Luzia

p. 54

Figura 9

Área central da comunidade Aningal

p. 60

Figura 10

Malocão principal da comunidade Aningal

p. 60

Figura 11 Centro Indígena de Formação e Cultura Raposa Serra do Sol

p. 63

Figura 12

Vista da antiga igreja do CIFCRSS

p. 63

Figura 13

Placa de identificação do CIFCRSS

p. 64

Figura 14 Mapa das comunidades na TI Raposa Serra do Sol

p. 66

Figura 15 Escola Estadual José Marcolino (a placa traz o nome antigo). Comunidade do Contão

p. 69

Figura 16

Áreas onde são realizados os projetos dos alunos de alternância no Contão

p. 69

Figura 17

Área organizada em fomas geométricas para as aulas de matemática

p. 70

Figura 18

Mapa das Terras Indígenas em Roraima

p. 71

Figura 19

Discentes da turma de alternância

p. 87

Figura 20

Formatura do curso técnico em alternância em Agropecuária, na Escola

Estadual José Marcolino, no Contão

p. 88

Figura 21

Escola Estadual Indígena José Joaquim (Comunidade Maruwai - TI São Marcos)

p. 94

Figura 22

Espaço de convivência chamado de "malocão"

p. 119

Figura 23

Gráfico: Comunidades e municípios dos/as alunos/as do CAM entrevistados/as

p. 124

Figura 24

Mapa das Terras Indígenas Raposa Serra do Sol e São Marcos

p. 125 


\section{LISTA DE TABELAS}

Tabela 1

Infraestrutura e serviços públicos das escolas com ensino médio regular - Roraima

p. 92 


\section{LISTA DE SIGLAS}

Alidcir Aliança de Integração e Desenvolvimento das Comunidades Indígenas de Roraima

Apirr

Caes

CAM

CIR

CIFCRSS

Cores

DA

$\mathrm{EE}$

EJA

Funai

IBGE

IF

IFRR

MEC

Odic

Omir

Opirr

Senac

Senai

Sodiur

TI

TWM

UFRR

Ufam
Associação dos Povos Indígena de Roraima

Coordenação de Assistência ao Estudante

Câmpus Amajari

Conselho Indígena de Roraima

Centro Indígena de Formação e Cultura Raposa Serra do Sol

Coordenação de Registros Acadêmicos

Departamento de Antropologia

Escola Estadual

Educação de Jovens e Adultos

Fundação Nacional do Índio

Instituto Brasileiro de Geografia e Estatística

Instituto Federal

Instituto Federal de Roraima

Ministério da Educação

Organização de Índios da Cidade

Organização das Mulheres Indígenas de Roraima

Organização dos Professores Indígenas de Roraima

Serviço Nacional de Aprendizagem Comercial

Serviço Nacional de Aprendizagem Industrial

Sociedade de Defesa dos Índios Unidos do Norte de Roraima para o Desenvolvimento

Terra Indígena

Sociedade para Desenvolvimento e Qualidade Ambiental

Universidade Federal de Roraima

Universidade Federal do Amazonas 


\section{SUMÁRIO}

INTRODUÇÃO

CAPÍTULO 1. A PESQUISA, AMAJARI E OS MACUXI .

1.1 A temática da educação escolar indígena ............................................................ 42

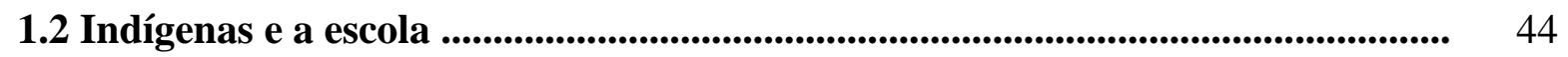

1.3 Amajari e suas características .................................................................... 49

1.4 Comunidade Três Corações ............................................................................. 51

1.5 Comunidade Guariba ................................................................................ 55

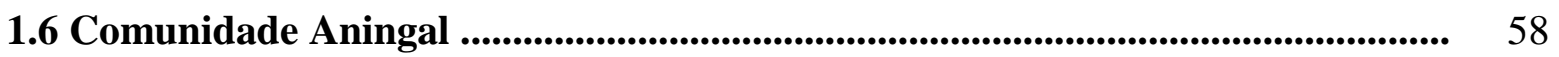

1.7 Comunidade Surumu ................................................................................................ 60

1.8 Comunidade do Contão .................................................................................... 66

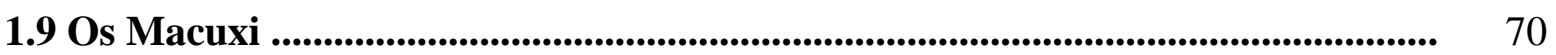

CAPÍTULO 2. ESTUDANTES MACUXI NO ENSINO MÉDIO DE RORAIMA • 74

2.1 Educação, trabalho e ensino integrado ................................................................... 74

2.2 O CAM e os estudantes no ensino médio de Roraima ............................................ 80

2.3 Ensino médio indígena em Roraima ...................................................................... 90

2.4 A educação escolar indígena em Roraima .......................................................... 98

2.5 Ensino superior para indígenas em Roraima ...................................................... 106

2.5.1 A Universidade Federal de Roraima 114

CAPÍTULO 3. OS ESTUDANTES MACUXI E SUAS DEMANDAS ...................... 118

3.1 Juventudes ................................................................................................................ 121

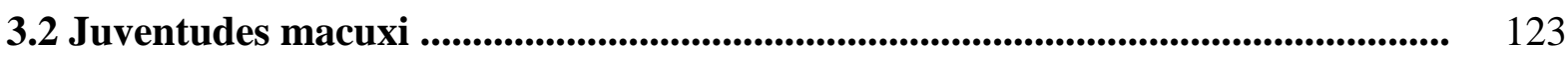

3.3 Jovens macuxi no CAM ............................................................................................... 132

CONCLUS

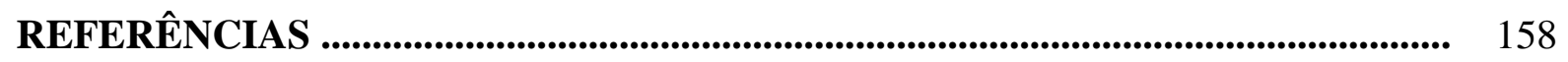




\section{INTRODUÇÃO}

Se encontrei-os menos intactos do que esperava, iria descobrilos mais secretos do que sua aparência poderia deixar supor.

(LÉVI-STRAUSS, 1996, p. 144)

Lévi-Strauss relata nos Tristes trópicos, quando ainda era um jovem etnógrafo nos idos de 1935, seu encontro com os indígenas que viviam às margens do rio Tibagi, no Paraná, e como ficou decepcionado por considerar aqueles povos uma mistura confusa de "selvagens" e "civilizados". Alguns anos depois, o autor refletiu sobre a maneira enganosa pela qual enxergou aqueles indígenas e como, após sua experiência, conseguiu entender que, mesmo tendo passado por um longo período de tentativas de colonização, aqueles povos criaram formas de sobrevivência que traziam elementos tanto dos colonizadores quanto da tradição de suas etnias e, ainda assim, mantinham-se indígenas.

De certa forma, e de maneira mais lenta, tive a mesma sensação que o jovem antropólogo quando se aventurou pelas terras paranaenses, a partir do momento em que passei a residir em Amajari, no estado de Roraima. Fui aprovado em um concurso para professor de História no Instituto Federal de Roraima (IFRR), no município de Amajari, interior do estado. Assim, passei a lecionar, desde setembro de 2015, no ensino básico e tecnológico (EBT). Consequentemente, iniciei a vivência de uma realidade totalmente nova e instigante para mim. Sou formado em História, fiz mestrado em História Social e tenho experiência, desde 1994, no magistério público e privado na cidade de São Paulo. Quando me deparei com a realidade roraimense, percebi o quanto a presença de indígenas em contexto urbano, universidades e escolas de Roraima é intensa, o que me surpreendeu e demonstrou minha ignorância sobre a realidade dos povos indígenas naquele momento.

Como grande parte das pessoas que vivem em metrópoles, tinha visão estereotipada dos povos indígenas no Brasil. Andrade (2012, p. 10) tratou da presença do povo Sateré Mawé na cidade de Manaus e abordou essa visão - trazida por influência de vários elementos da literatura, do cinema, das mídias e do senso comum - segundo a qual associamos os povos indígenas à floresta.

Embora imaginasse encontrar os indígenas em suas comunidades vivendo da agricultura, da pesca e da caça, encontrei-os em várias atividades, inclusive como meus colegas de trabalho no Câmpus Amajari (CAM). Essa realidade, localizada em uma área rural e em uma escola considerada do campo, é igualmente comum em grandes metrópoles. Mesmo vindo de uma, não tinha percebido tal circulação dos indígenas em São Paulo: a metrópole paulistana é 
a quarta em população indígena, segundo a Comissão Pró-Índio de São Paulo (2013, p. 26). Segundo a ONU-Habitat, citada nessa mesma publicação (p. 9), a presença dos indígenas nas cidades é resultado de dois fatores principais:

o crescimento das cidades, que alcançam as terras indígenas e as englobam na área urbana; e a migração dos índios para as cidades (...) A migração para as cidades pode ser voluntária ou forçada e, em muitas situações, envolve violação de direitos humanos, como nos casos em que é motivada pela expulsão de suas terras de origem, insegurança econômica, ausência ou precariedade de serviços básicos ou ainda por conflitos armados.

O mesmo documento aponta a educação como um dos motivos para a vinda de indígenas para regiões urbanizadas. Seus autores citam casos similares em Belém, Campo Grande, Curitiba, Manaus, Porto Alegre e São Paulo, nos quais ocorrem situações favoráveis ou não ao desenvolvimento de uma educação escolar indígena diferenciada ${ }^{1}$ (COMISSÃO PRÓ-ÍNDIO DE SÃO PAULO; CENTRO GASPAR GARCIA DE DIREITOS HUMANOS, 2013, p. 31 39). Em Roraima, na capital Boa Vista, a educação também é apontada pelos indígenas como um dos motivos importantes para os deslocamentos para as áreas urbanizadas (REPETTO, 2008b, p. 33).

Essa realidade era desconhecida para mim, quando cheguei ali. A capital do estado tem em suas origens uma formação pluricultural, pois, além de reunir os povos indígenas da região, também se constitui de moradores/as de várias partes do Brasil, da Venezuela e da Guiana. Quem visita a cidade pode ver a presença das/os migrantes e imigrantes, assim como a circulação dos indígenas em várias organizações, escolas, universidade ou diversos tipos de trabalho nos quais eles e elas atuam (MELO, 2012, p. 48).

Amajari, por sua vez, possui características diferentes. A cidade fica a $156 \mathrm{~km}$ da capital, sendo necessário percorrer $100 \mathrm{~km}$ pela BR-174 em direção a Pacaraima e mais $56 \mathrm{~km}$ pela rodovia estadual RR-203. Esse percurso tem como paisagens a savana típica da região, chamada de lavrado, e as entradas para diversas comunidades indígenas que circundam a cidade. A seguir, um mapa dos campi do IFRR em Roraima, tendo em azul a localização da cidade de Amajari e do Câmpus Amajari; e, logo abaixo, um mapa localizando as terras indígenas no estado, mostrando a proximidade do CAM com as terras indígenas e as diversas comunidades indígenas ao seu redor.

1 Segundo Clarice Cohn, "por ela deve se assegurar a inclusão da língua, da cultura e dos saberes indígenas no projeto curricular dessas escolas e o respeito à particularidade étnica dessas populações, reunindo alunos e professores de uma mesma etnia em seu projeto, execução e gestão" (2005, p. 489). 
Figura 1 - Mapa dos campi do IFRR no estado de Roraima

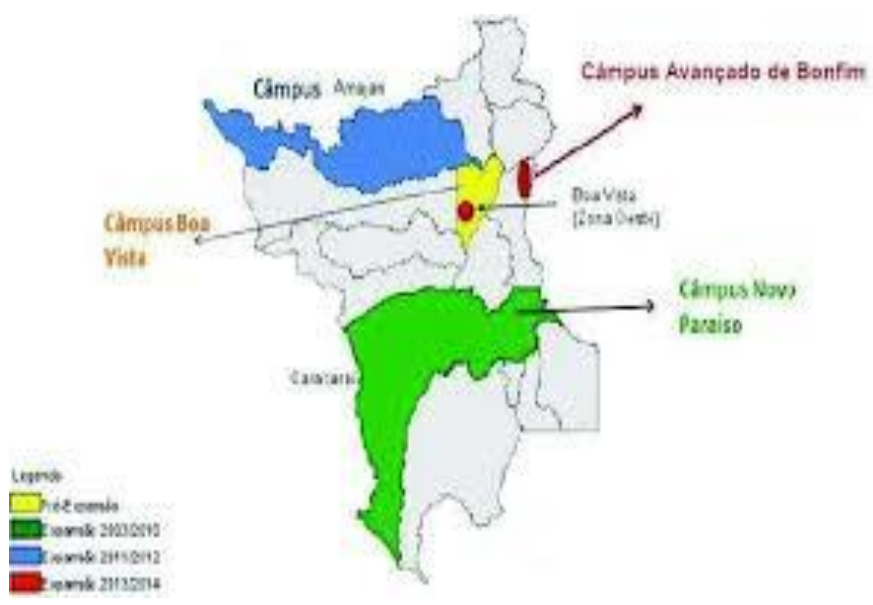

Fonte: Brasil, MEC/SETEC.

Figura 2 - Mapa das Terras indígenas demarcadas no estado de Roraima

\section{TERRAS INDIGENAS DEMARCADAS NO ESTADO DE RORAIMA}

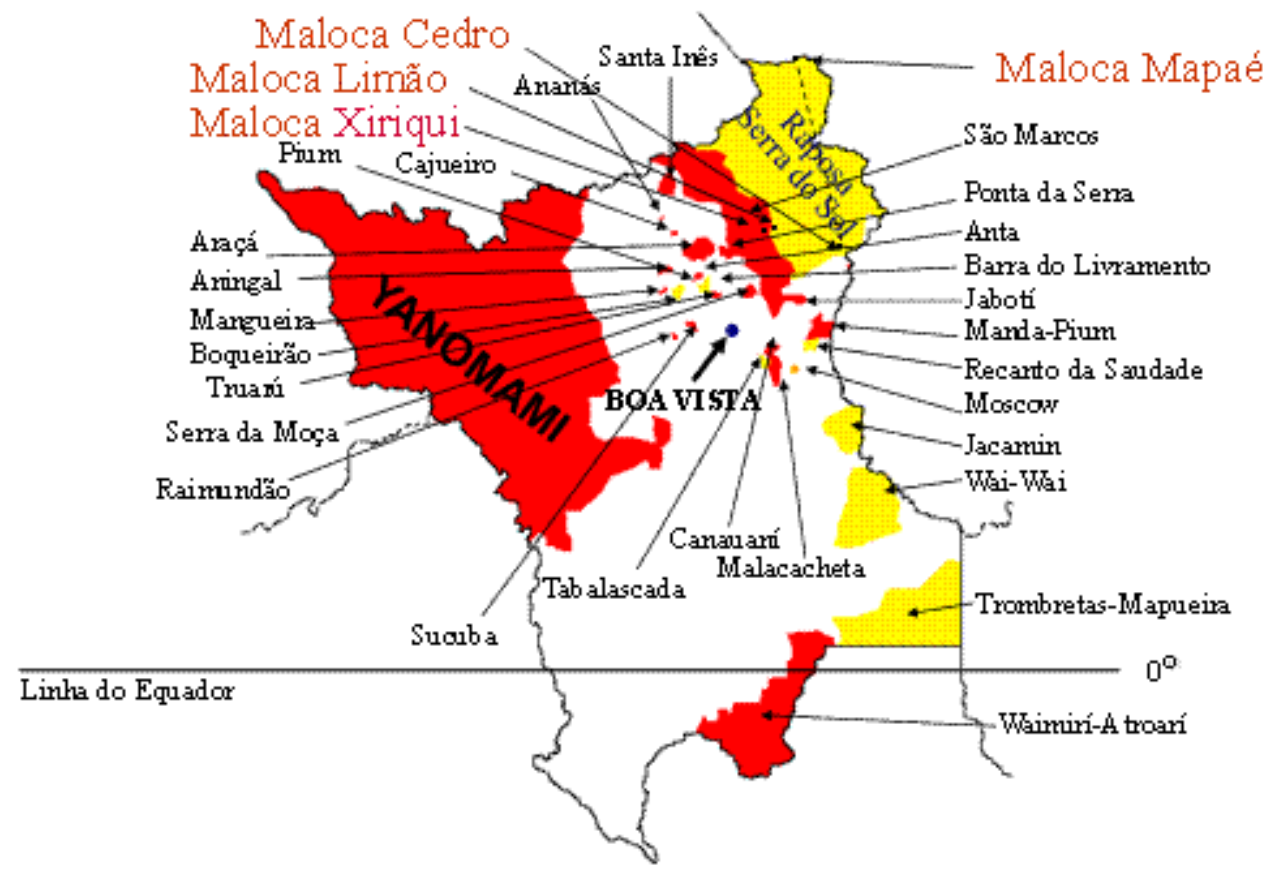

Fonte: Folha Web de Boa Vista ${ }^{2}$.

2 FOLHA WEB. 83, 2 \% dos indígenas vivem em Roraima, diz IBGE. Atlas Digital. 01/07/2016. Disponivel em: https://folhabv.com.br/noticia/CIDADES/Capital/83-2 - dos-indigenas-vivem-em-Roraima--dizIBGE/17782. Acesso em: 28 nov. 2020. 
A sede do Instituto Federal fica na pequena Vila Brasil, com uma estrutura mínima para os servidores morarem e trabalharem. Conta com pouco mais de mil habitantes e se caracteriza pela precariedade da comunicação e do transporte. Para se chegar à cidade partindo de Boa Vista ou vice-versa, é necessário utilizar táxi-lotação que atende de acordo com a quantidade máxima de passageiros, não obedecendo a um horário fixo. Há, além disso, um ônibus que faz o trajeto saindo pela manhã e à tarde, ou a possibilidade de contar com a boa vontade de colegas que fornecem carona em troca de uma contribuição pelo gasto com combustível. Na Vila Brasil, localiza-se o câmpus, com comunicação via celular e Internet muito precárias. A instituição dispõe de conexão de Internet por satélite, que sofre várias oscilações. Para os moradores, a Internet é fornecida apenas por duas operadoras de telefonia celular, ou via rádio, que costuma ser caro e limitado.

Figura 3 - Vista área da Vila Brasil, distrito-sede do município de Amajari

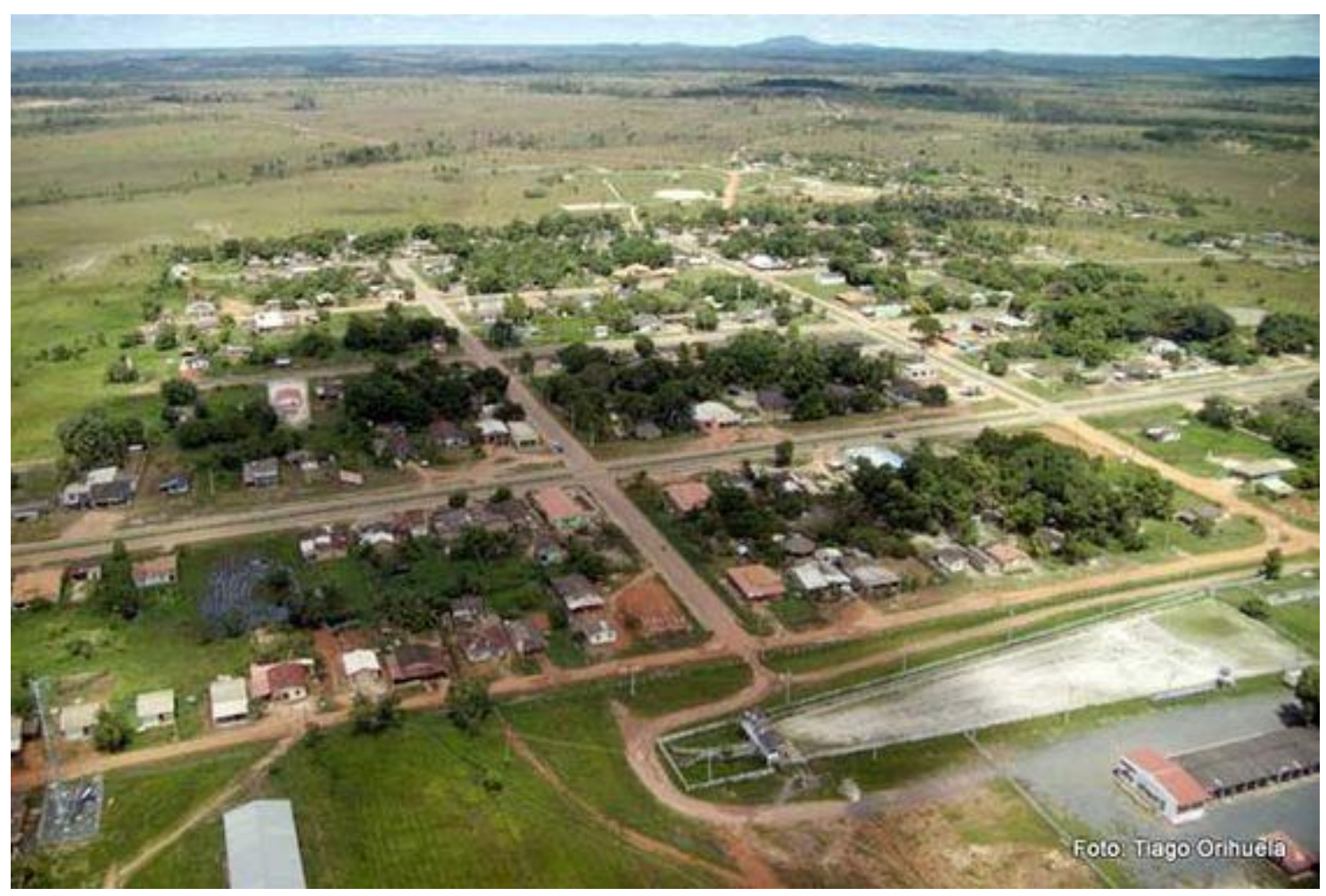

Fonte: Thiago Orihuela. 
Figura 4 - Câmpus Amajari do IFRR

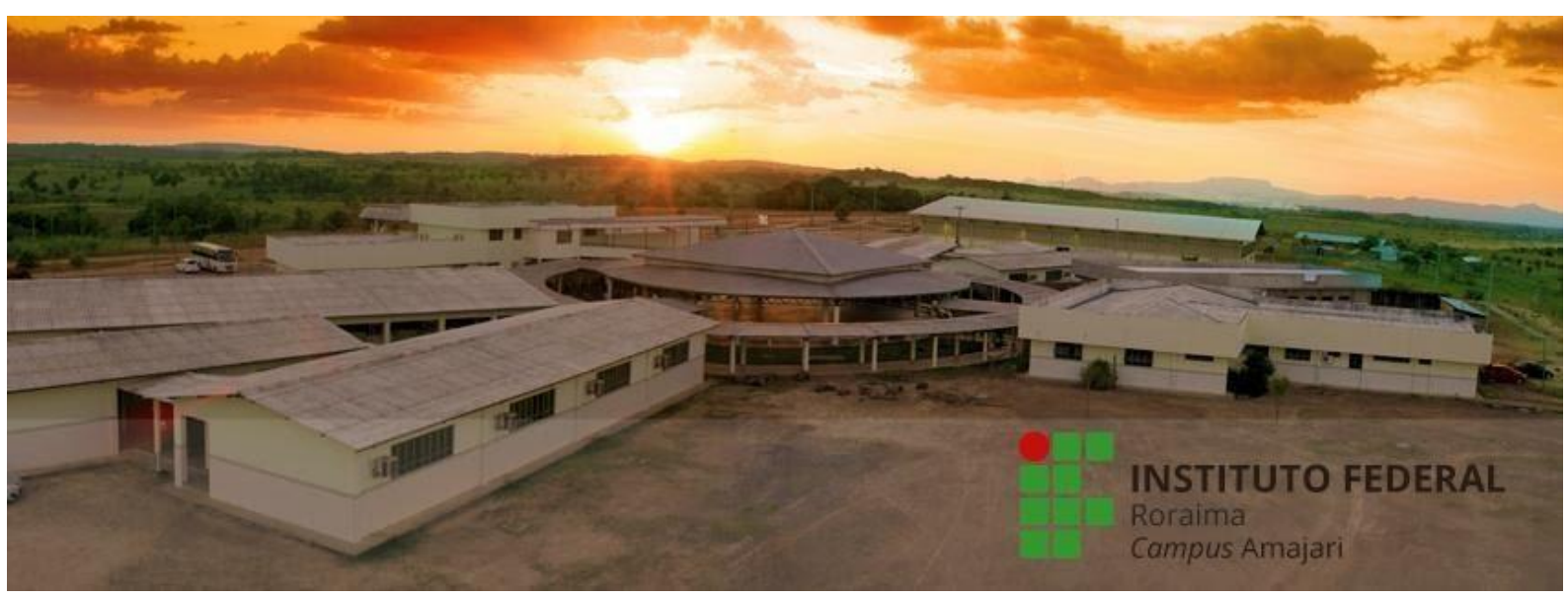

Fonte: Ramon Oliveira de Queiroz, 2015.

A área total do Câmpus Amajari é de 256 hectares e conta com a seguinte estrutura física: um bloco para área administrativa com dois pisos; dois blocos para ensino, pesquisa e extensão, com oito salas de aula, três laboratórios e uma biblioteca; um restaurante; dois alojamentos (feminino e masculino); casa de apoio para o coordenador de alojamento; ginásio poliesportivo, com academia; área de convivência em forma de tapiri³; laboratório de aquicultura; almoxarifado.

Nessa região tive meus primeiros contatos com os/as alunos/as do câmpus, que, em sua maioria, são indígenas. Pude identificar a presença das etnias macuxi, wapichana, sapará, ingarikó, taurepang e, mais recentemente, ye'kuana, que frequentavam e, em alguns casos, ainda frequentam a unidade escolar pesquisada ${ }^{4}$.

A presença dessas etnias é numerosa, chegando a mais da metade do corpo discente da instituição. Dos 440 alunos/as, 240 são estudantes que se autodeclararam indígenas ${ }^{5}$. Tal contexto propiciou uma reflexão sobre as/os discentes e sobre o que eles/as anseiam quanto a essa instituição. Imaginei, quando cheguei, que o Câmpus Amajari tivesse um olhar especial

3 A estrutura de tapiri é uma habitação tradicional indígena que pode funcionar como um pequeno e provisório abrigo, feita de palha. Também pode se referir ao espaço construído para se defumar a borracha nos seringais durante o Ciclo da Borracha.

4 Para a grafia dos etnônimos indígenas, adoto na tese a "Convenção sobre a grafia dos nomes tribais" da Associação Brasileira de Antropologia. Essa convenção recomenda o uso da letra maiúscula quando o etnônimo indígena for um substantivo, mas faculta a letra minúscula no uso adjetival desses termos.

5 Disponível em: http://amajari.ifrr.edu.br/noticias/dia-do-indio-ifrr-amajari-garante-acesso-a-educacaoprofissional-de-comunidades-indigenas. Acesso em: 22 ago. 2019. 
para os grupos indígenas. Entretanto, havia pouca ou nenhuma preocupação com essa parcela de $56 \%$ dos estudantes em 2015.

Figura 5 - Gráfico: Etnias presentes no Câmpus Amajari em 2017

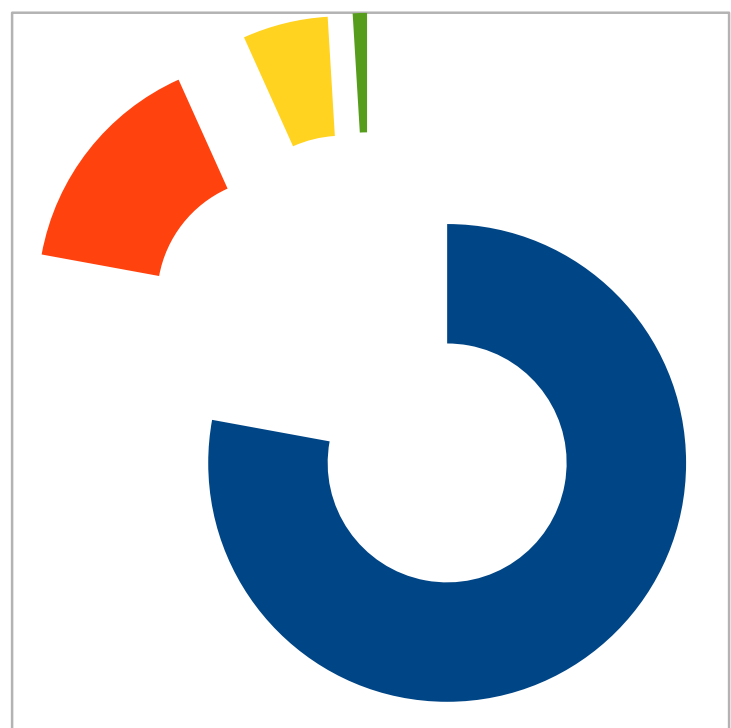

- Macuxi (81 estudantes - 78\%)

- Wapichana (16 estudantes - 15\%)

- Taurepang (6 estudantes $-6 \%)$

- Sapará (1 estudante - 1\%)

Fonte: Dados coletados pelo autor.

Apesar de a região ser considerada rural, é necessário entender que o próprio conceito de rural tem sido flexibilizado. Algumas regiões estão muito próximas de cidades maiores, como é o caso de Amajari. Esses espaços chamados de rurais têm apresentado crescentes características de ambientes urbanos, e muitas vezes fica difícil perceber as fronteiras entre as duas lógicas. Segundo Ponte,

o rural deve ser entendido como um território criado pelas relações econômicas, sociais e políticas que a população do campo estabelece com a terra. Portanto, considera-se que ao mesmo tempo em que os dados quantitativos apresentam contribuições para se compreender o rural, a ênfase maior se dá para as relações estabelecidas no campo. Essas permitem uma análise qualitativa sobre a realidade, representando variáveis relevantes que permitem entender toda a dinâmica e a peculiaridade desses territórios. (2004, p. 24)

Assim sendo, para um observador desatento, o corpo discente é muito parecido com o da maioria das/os adolescentes que estão em qualquer outra instituição escolar do país, a não ser pela presença marcante de indígenas. As/os estudantes circulam com seus celulares e fones de ouvido e têm as mesmas angústias e dúvidas de qualquer jovem estudante. As/os docentes, a maioria oriunda de outros estados e vinda de grandes cidades, mantêm seus costumes e, assim como o autor-pesquisador, tinham ou têm uma visão estereotipada dos indígenas. No entanto, as intervenções institucionais e a rotatividade do câmpus paulatinamente têm colaborado para uma mudança positiva dos servidores com relação à diversidade cultural da instituição. 
Mudança que foi impulsionada pela nomeação, em 2016, de uma diretora de ensino da etnia wapichana, com experiência no movimento indígena local, bem como pela perspicácia do diretor-geral, que veio permitindo ações de estímulo e respeito às diferenças culturais.

A instituição já tinha seis anos quando fui nomeado e, até aquele momento, ainda não havia sido realizada nenhuma discussão sobre a questão indígena entre os alunos e sua comunidade escolar, mesmo sendo do conhecimento da direção e da coordenação pedagógica os vários casos de tensão entre estudantes não indígenas e indígenas. Tais conflitos, entre outros motivos, vinham ocasionando uma grande porcentagem de alunos evadidos ou retidos por questões pessoais, segundo o documento Plano estratégico institucional para a permanência e êxito dos estudantes do IFRR-Câmpus Amajari (IFRR, 2016, p. 25).

Figura 6 - Gráfico: Causas da evasão e retenção no CAM em 2013

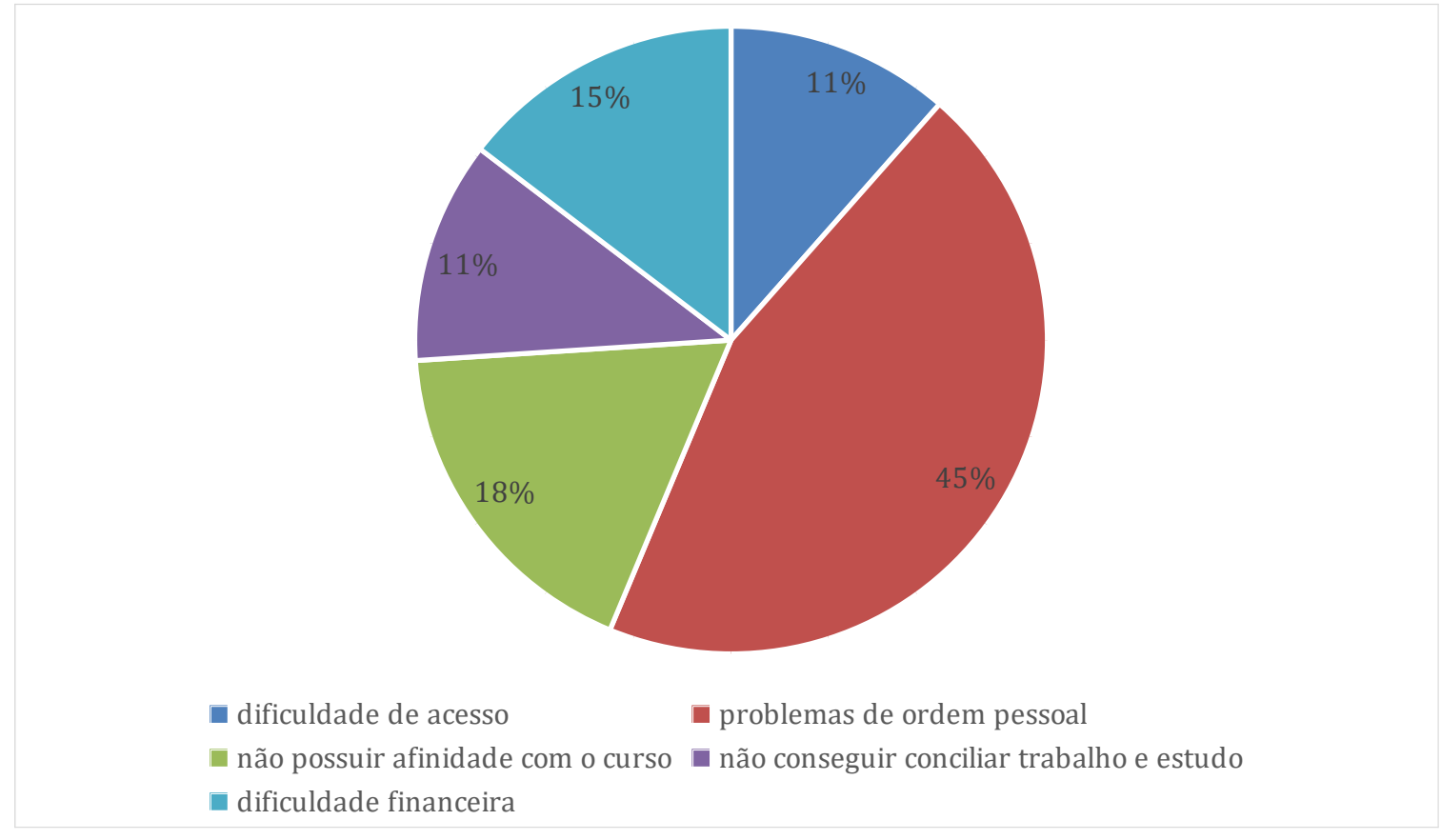

Fonte: Gráfico elaborado pelo autor.

Diante dessa realidade, realizei um projeto aceito pela Pró-Reitoria de Ensino do IFRR em 2016, que incentivava práticas pedagógicas inovadoras na instituição para propostas com docentes das áreas de Português, Artes e Zootecnia. Intitulado "Diversidade cultural e suas implicações no ambiente escolar", o projeto buscava relacionar questões das comunidades indígenas locais aos conteúdos programáticos das disciplinas envolvidas, realizar visitas técnicas à comunidade indígena Boca da Mata para participar dos festejos do Dia do Índio e visitar o sítio arqueológico Pedra Pintada, dentro da Terra Indígena São Marcos. Estudantes e servidores/as participaram de debates sobre cultura e arte indígena com o artista plástico macuxi 
Jaider Esbell e com o escritor indigenista Ricardo Dantas. O projeto concluiu-se com a criação do Museu da Imagem e da Memória Indígena, localizado na mesma instituição educacional (OLIVEIRA, M., 2019) ${ }^{6}$.

A dissertação de Lima (2018) sobre a retenção e a evasão nos campi do IFRR de Amajari e de Boa Vista na Zona Oeste (CBZO) também fornece alguns dados interessantes sobre os números e motivos desses problemas. A autora conversou e realizou pesquisa com questionário envolvendo 46 estudantes do CAM dos cursos de ensino médio integrado em Agropecuária e Aquicultura, sendo 9 estudantes com algum tipo de dependência em alguma matéria, ou seja, que foram reprovados em alguma disciplina e, durante os cursos, estavam acompanhando essas disciplinas novamente - enquanto os demais estavam sem essas dificuldades. A pesquisa constatou que os e as estudantes do CAM apresentaram reprovações em disciplinas da base comum curricular, principalmente Matemática e Português, durante o ensino fundamental, o que, segundo a autora, seria uma possibilidade de entendimento do alto número de estudantes com dependência nos cursos integrados de ensino médio do CAM, que chegou a $46 \%$ dos alunos e alunas participantes (p. 57-58).

Segundo Lima, $100 \%$ dos alunos e alunas do CAM afirmaram terem enfrentado problemas familiares por "ficar de dependência", o que, em certa medida, atrapalha o andamento do aprendizado (2018, p. 61). A autora identificou em quais disciplinas predominavam as "dependências" no CAM, a saber: Química, Português, Inglês, Geografia, Física, Biologia, História, Matemática, Sociologia e Educação Física. Segundo a autora, isso caracterizava a dificuldade trazida por esses e essas estudantes do ensino fundamental (p. 62).

As reprovações, segundo Silva (2018, p. 63), são muito maiores no $1^{\circ}$ ano, por exemplo no $1^{\circ}$ Módulo (60\%) e no $2^{\circ}$ Módulo (40\%), o que caracteriza o impacto causado para a adaptação dos alunos e alunas à nova situação que passam a viver na instituição, saindo de escolas estaduais sem estruturas integralizadas, com ausências constantes de professores e professoras e de cursos regulares, e passando a viver em situação de alojamento, com carga horária maior e tendo contato com disciplinas com as quais quase não tiveram contato no período anterior. No Capítulo 2 desta tese, aprofundaremos essas diferenças.

A partir dessas experiências, pude refletir sobre a realidade dos/as estudantes indígenas daquele câmpus e comecei a me questionar sobre o que motivava esses estudantes a se

6 Com a minha saída em agosto de 2016 para a realização do doutorado, o projeto do Museu foi interrompido. Não houve disposição de continuá-lo pela instituição por vários motivos, como dificuldades de espaço, de organização do acervo e de envolvimento dos e das discentes. 
deslocarem até a unidade escolar para terem contato com uma instituição não indígena e com práticas de escolarização convencionais e homogeneizantes, quando poderiam, se quisessem, estudar em escolas indígenas em suas comunidades de origem, que mantinham professores/as indígenas e, em alguns casos, preservavam o ensino da língua materna.

O estado de Roraima costuma ser considerado um local de forte luta pela implantação de uma educação escolar indígena diferenciada na Região Norte. A maioria das comunidades tem escolas indígenas com professores/as indígenas e ensino das línguas macuxi, wapichana e ingarikó, além de haver a escola indígena yanomami (FREITAS; TORRES, 2016, p. 753-755). Uma característica muito marcante dessas escolas indígenas roraimenses é a relação bem integrada que mantêm com a comunidade. Ambas, escola e comunidade, elaboram em conjunto um calendário, e mensalmente é feita uma reunião na qual a comunidade discute com integrantes da escola os avanços e problemas. Os professores e alunos são avaliados também pela comunidade e a esta devem prestar contas. Por fim, os diretores das unidades escolares são selecionados pela comunidade entre os professores habilitados, para um mandato de dois anos (REPETTO, 2012a, p. 140). Assim, parecia surpreendente os alunos buscarem o Instituto, mesmo tendo opções de escolas muito mais próximas de suas realidades.

Diante dessa peculiaridade local, a leitura de Soratto (2007) foi inquietante, pois ela tentou compreender algo semelhante. Tratou de interpretar como foi construído o sentido de escola para estudantes indígenas do ensino médio localizado na Reserva Francisco Horta Barbosa (Dourados, MS), na Escola Estadual Intercultural Guateka Marçal de Souza, da aldeia Jaguapiru. Segundo Soratto,

\begin{abstract}
o sentido da escola para os estudantes indígenas do Ensino Médio parece responder a um desafio padrão, todos veem na escola o espaço de formação para contribuir para o desenvolvimento social e econômico da comunidade, buscando capitalizar bens materiais e ter ascensão social. A construção do sentido da escola é um processo contínuo, sempre em reelaboração, produzido historicamente e no dia a dia dos estudantes, fruto das incertezas e contradições "do que eu sou" e o "que eu quero ser" (2007, p. 8).
\end{abstract}

O que levava as/os estudantes guarani-kaiowá e terena a estarem em uma escola indígena de ensino médio era o desejo de trazerem um "desenvolvimento econômico e social" para si ou para a comunidade, ainda que esse conceito exija uma interpretação mais precavida, sendo preciso refletir sobre as variáveis que caracterizam os povos e sociedades indígenas. Muitas ideias correm o risco de sugerir uma semelhança com a sociedade envolvente, marcada pelo capitalismo neoliberal, e, assim, levarem a um entendimento inadequado desses povos. Ocorre que tal desejo por "desenvolvimento econômico" está associado a uma ideia de 
consumismo e urbanismo, que, no caso de Roraima, acabou gerando visões contraditórias do desenvolvimento, tanto entre indígenas quanto entre não indígenas.

Um estudo de Repetto (2008b) sobre os movimentos indígenas em Roraima aponta essa confusão quando a sociedade roraimense discutia a regulamentação da Terra indígena (TI) Raposa Serra do $\mathrm{Sol}^{7}$. Naquele momento, os não índios enxergaram na demarcação da TI um empecilho para o "desenvolvimento econômico" do estado, pois impediria o "crescimento" gerado pela rizicultura e pela mineração, que ocorriam nas terras a serem demarcadas.

A Terra Indígena Raposa Serra do Sol está localizada ao norte do estado de Roraima, na fronteira com a Venezuela a noroeste e, a nordeste, com a República Federativa da Guiana, em uma região que ocupa aproximadamente 7,5\% do estado roraimense. A vegetação de seu território é conhecida como lavrado, favorável à criação de gado e ao cultivo de arroz, milho e feijão, por possuir grandes várzeas. A área causa a cobiça de fazendeiros e políticos locais e, sendo rica em minérios como ouro e diamantes, entre outros, atrai garimpeiros, que já realizaram exploração nos anos de 1980-1990 nessa TI (ALONSO, 2013, p. 30-31).

Os conflitos em torno da demarcação da TI Raposa Serra do Sol opuseram grupos desfavoráveis à demarcação, que acreditavam que essas riquezas naturais não poderiam ficar com os povos indígenas pois impediriam o "crescimento econômico" roraimense. Tais grupos incluíam rizicultores, migrantes garimpeiros, políticos locais e o Exército, que via a demarcação em área fronteiriça como um perigo à "segurança nacional".

Os favoráveis à demarcação eram os indígenas, representados por suas organizações, principalmente o Conselho Indígena de Roraima (CIR), missionários católicos ligados ao Conselho Indigenista Missionário (Cimi) e organizações indigenistas que defendiam o direito constitucional dos povos indígenas.

A discussão gerou em algumas lideranças indígenas da região o apoio à demarcação “em ilhas", estimuladas por uma prática dos agentes da Funai, influenciadas pelo discurso do "desenvolvimento econômico", ou por serem trabalhadores das fazendas, garimpeiros ou proprietários de terras. Afirmavam que a demarcação “em ilhas” permitiria a presença dos não índios e manteria os empregos, indústrias, escolas e melhorias materiais na sociedade

7 A TI Raposa Serra do Sol teve sua área formalmente identificada pela Fundação Nacional do Índio (Funai) em 1993, com a publicação no Diário Oficial da União do seu memorial descritivo com as coordenadas geográficas do perímetro proposto para demarcação. Esta privilegiou limites naturais e excluiu a cidade de Normandia e as terras no seu entorno. Todo o processo durou 12 anos, período em que ocorreram invasões por arrozeiros, a criação do município de Uiramutã e o assassinato de 21 lideranças indígenas com o intuito de impedir a homologação da TI, que finalmente veio a ocorrer em 2005. Disponível em: https://especiais.socioambiental.org/inst/esp/raposa/. Acesso em: 11 set. 2019. 
roraimense e na região demarcada. Outras lideranças defendiam a demarcação em terras contínuas, o que implicaria a saída dos não índios, pois acreditavam ser capazes de gerir seu próprio desenvolvimento. ${ }^{8}$ Esta segunda proposta acabou prevalecendo e foi vista como um erro pela mídia e grupos econômicos do estado. Nas palavras de Repetto (2008b, p. 91):

Desse modo, o significado do termo "desenvolvimento" oscila entre campos semânticos que ora privilegiam os aspectos econômicos e culturais e ora todo o campo social e simbólico. É importante chamar a atenção para o fato de que essas diferenças de sentido nos usos do termo decorre de cada grupo interpretar a questão a partir de seus próprios moldes culturais e ideológicos. Neste contexto, as incertezas sobre o impacto do desenvolvimento na vida das comunidades é inquietante e, o que é pior, ela impede a própria compreensão da questão.

Concordo com Ferreira (2015), para quem as realidades indígenas exigem uma variedade de soluções que não se restringem a reproduções de nossas realidades sociais, mas de opções próprias que escapam de definições fechadas ou imperativas:

as comunidades indígenas têm o direito de pensar o desenvolvimento de modo diferente do padrão, pois é indispensável reconhecer que esse desenvolvimento seja visto a partir de outros paradigmas que professem a qualidade de vida, bem estar e felicidade. Tratase, assim, de garantir a liberdade dos grupos étnicos indígenas de viver e buscar o seu bem estar e a sua felicidade segundo seus próprios padrões de necessidades básicas e suas respectivas escalas de valores. Somente por meio da liberdade dos grupos étnicos, de acordo com seus próprios padrões de necessidades básicas e seus respectivos valores. (FERREIRA, 2015, p. 68)

Esse ponto de vista se expressa ainda nas palavras das/os indígenas de Roraima que vivem na TI Raposa Serra do Sol, constantes de seu documento sobre os resultados e ações naquele período de demarcação:

A demarcação integral da Terra Indígena Raposa Serra do Sol é um exemplo importante de reconhecimento pleno dos direitos dos povos indígenas no Brasil. Não há argumentos antropológicos ou jurídicos que vinculem o direito pleno à terra indígena a um certo desenvolvimento sócio-cultural e econômico entre os povos envolvidos. O direito pleno à nossa terra ancestral é justamente para permitir que possamos viver do nosso jeito e construir um futuro baseado nas nossas visões de progresso e bem estar. A homologação da T. I. Raposa Serra do Sol resultou na diminuição visível dos conflitos diretos e indiretos sobre terra em Roraima. A tranquilidade de não sermos atacados em nossas próprias casa e roças tem um valor e um efeito incalculável para as nossas comunidades. (DOSSIÊ, 2017, p. 11)

8 Reportagem da Folha de S. Paulo (11/02/2019) tratando dos 10 anos de comemoração da demarcação da TI Raposa Terra do Sol mostrava a situação de aumento da população indígena em $32 \%$ depois da saída dos não índios e da manutenção do rebanho de bovinos da região, representando, junto com a TI São Marcos, 50.437 cabeças de gado, o equivalente a 6,2\% do total do rebanho do estado. A matéria demonstrava o sucesso da demarcação para os indígenas residentes na TI. Em contrapartida, aquele que se tornaria presidente da República em 2019 expressava seu desejo de retomar a região para os rizicultores para trazer "desenvolvimento" tanto para os indígenas como para o estado de Roraima. Disponível em: https://www1.folha.uol.com.br/poder/2019/02/dezanos-apos-vitoria-no-stf-indigenas-se-preparam-para-enfrentar-bolsonaro-em-rr.shtml. Acesso em: 11 fev. 2019. 
Em sentido semelhante, Gasché (2012, p. 34) esclarece, com base em sua experiência de dez anos com os moradores das florestas amazônicas do Peru e Equador e das florestas e savanas do Chile, a visão dos povos "bosquesinos" e suas diferenças com as das sociedades não indígenas:

\begin{abstract}
De esta preferencia motivadora que el bosquesino da a la ricura antes que a la riqueza deriva todo el malentendido entre promotores urbanos y comuneros bosquesinos. Para los desarrollistas, políticos y planificadores de la ciudad, el dinero, el aumento de ingresos monetarios y la aspiración a la riqueza constituyen la motivación humana fundamental que, según ellos, debería impulsar cambios en las actividades y un desarrollo expresado en un mayor consumo de productos industriales. Al tomar esta motivación por mayores ingresos de dinero como un valor universal, común a todos los seres humanos, se equivocan, pues aunque el bosquesino a veces se motiva por actividades que le procuran dinero, no acepta cualquier trabajo para lograr este objetivo. Sus preferencias siempre van a la vida placentera, "rica" -a la ricura-, no a la acumulación de dinero para hacerse "rico", no a la riqueza.
\end{abstract}

Sendo assim, entendo que o "desenvolvimento econômico e social" deva ser produzido e interpretado de acordo com cada povo ou nação indígena, que devem conduzir seus processos próprios de desenvolvimento. Daí a minha preocupação com a percepção das/os estudantes indígenas em relação à sua escolarização e aos sentidos que davam para sua escola.

Abbonizio (2013) também adotou essa perspectiva em sua pesquisa sobre uma comunidade no alto rio Uaupés, situada no município amazonense de São Gabriel da Cachoeira: a escola indígena Khumuno Wu'u do povo Kotiria. A escolarização nesse grupo conciliava os objetivos comunitários com os escolares, o que a constituía como um exemplo de inovação educacional.

Inovação educacional para Ghanem (2016, p. 205) define diferentes práticas educacionais que não seguem fazeres costumeiros, o que não necessariamente implica em algo totalmente original. $\mathrm{O}$ exemplo das escolas indígenas é pertinente porque, segundo o autor, o costumeiro seria uma escola colonialista, ao mesmo tempo civilizatória e catequizadora, que assume "o pressuposto central de que os povos indígenas não têm conhecimentos passíveis de serem objeto de aprendizagem no ambiente escolar". As escolas dos Tuyuka e dos Kotiria apresentam características inovadoras porque

os objetivos das escolas são compatíveis com aqueles dos povos que as utilizam, sendo ao menos conhecidos e dialogados com as comunidades. Consideraram-se também relatos assistemáticos de que a avaliação dos alunos, dos processos que as escolas desencadeiam nas comunidades, ou dos professores, é acompanhada e implementada pelas próprias comunidades em conjunto com os poderes públicos. Além disso, admitiram-se indicações de que os professores indígenas têm efetiva participação em todo o processo da educação escolar, em constante diálogo com as comunidades. Finalmente, a superação da educação colonialista foi sugerida pela crença de que o processo de escolha dos saberes que são objeto de ensino leva em conta aspirações de futuro das comunidades em que as escolas atuam. (GHANEM. 2016, p. 205) 
Essas obras contribuíram com a minha definição dos pressupostos teóricos e caminhos para desenvolver o projeto da pesquisa aqui apresentada. $O$ tema surgiu com um sentimento de surpresa ao verificar a presença elevada de estudantes indígenas em uma instituição de ensino médio técnico e profissionalizante não indígena, em uma região cujo número de escolas indígenas consideradas diferenciadas é grande. Essa dúvida também ocasionou a reflexão sobre a condição dos/as estudantes indígenas. Consoante o que indica Dal Bó (2018), a trajetória das/os estudantes indígenas que chegam às universidades, invariavelmente obrigados a passar pelo ensino médio, é um longo processo de formação no qual a escolarização produz diversos resultados.

Se não tivessem enfrentado essa formação, os/as interlocutores/as desse trabalho não
estariam onde estão e, mais do que isso, se não a tivessem enfrentado com resistência
tampouco estariam na universidade. Resistir à escola e à universidade não significa
delas abrir mão, e sim construir uma formação crítica, questionadora, inquieta. A
escolarização, do modo como foi (e em muitos locais continua sendo) oferecida aos
povos inḉgenas no Brasil, pode ser aniquiladora de modos indígenas de existir e de
pensar, mas ela nem sempre atinge esse fim. (DAL BÓ, 2018, p. 20)

A escolarização que esses/as estudantes têm recebido ao longo do seu percurso na educação básica em Roraima foi marcada, como veremos no Capítulo 2 desta tese, por uma íntima relação com a luta por direitos e garantias da posse de suas terras. Também por uma necessidade de sobrevivência em virtude da constante aproximação da sociedade envolvente, seja por meio das escolas catequizadoras e colonizadoras, seja pela construção das rodovias que cruzaram os territórios indígenas, seja com os fazendeiros, mineradoras ou garimpeiros que ocuparam seus territórios. Essa aproximação trouxe relações interétnicas intensas, que envolveram indígenas de etnias diferentes ou não indígenas, e posteriormente gerou conflitos entre os jovens, que passaram a ingressar no ensino médio sem se preocupar com questões da luta anterior por suas terras. São jovens de uma geração que cresceu em suas comunidades com esse direito garantido, não o considerando menos importante, mas tendo outros no horizonte pessoal (REPETTO, 2006, p. 58).

Esses e essas adolescentes indígenas, que frequentavam o Câmpus Amajari durante minha experiência de docente, apresentavam muita vontade de aproveitar o espaço conquistado e também demonstravam dificuldades de adaptar-se às inúmeras situações às quais estavam sujeitos em uma instituição que os tratava de forma homogênea no processo de aprendizagem. Todavia, em "atividades culturais" ou no momento de receberem os benefícios oriundos das ações afirmativas, quando eram levados a revelar sua identidade originária, eram vistos de forma específica. 
Era evidente a necessidade de suas identificações serem cada vez mais pautadas pelo olhar dos não indígenas nas entrevistas exigidas para a matrícula, momento no qual sua origem indígena apontada na inscrição era requerida com documentos e comprovantes de ligações com as comunidades. Da mesma forma nas festividades da semana dos povos indígenas, ou em atividades em que suas identidades étnicas precisavam se explicitar para que pudessem se diferenciar dos demais discentes, com trajes ou danças típicas.

Embora a identidade étnica esteja juridicamente definida a partir do conceito de autoidentificação e adscrição, essas populações se apercebem por meio da expectativa da população brasileira de que os índios pareçam índios e, assim, se pintam, fazem para si cocares (diante da falta de penas de arara, com penas de aves criadas) e utilizam tangas. Apropriam-se, portanto, do estereótipo que nossa sociedade criou para os índios. (COHN, 2001, p. 41)

Figura 7 - Alunos/as do CAM nas comemorações da semana dos povos indígenas em 2019

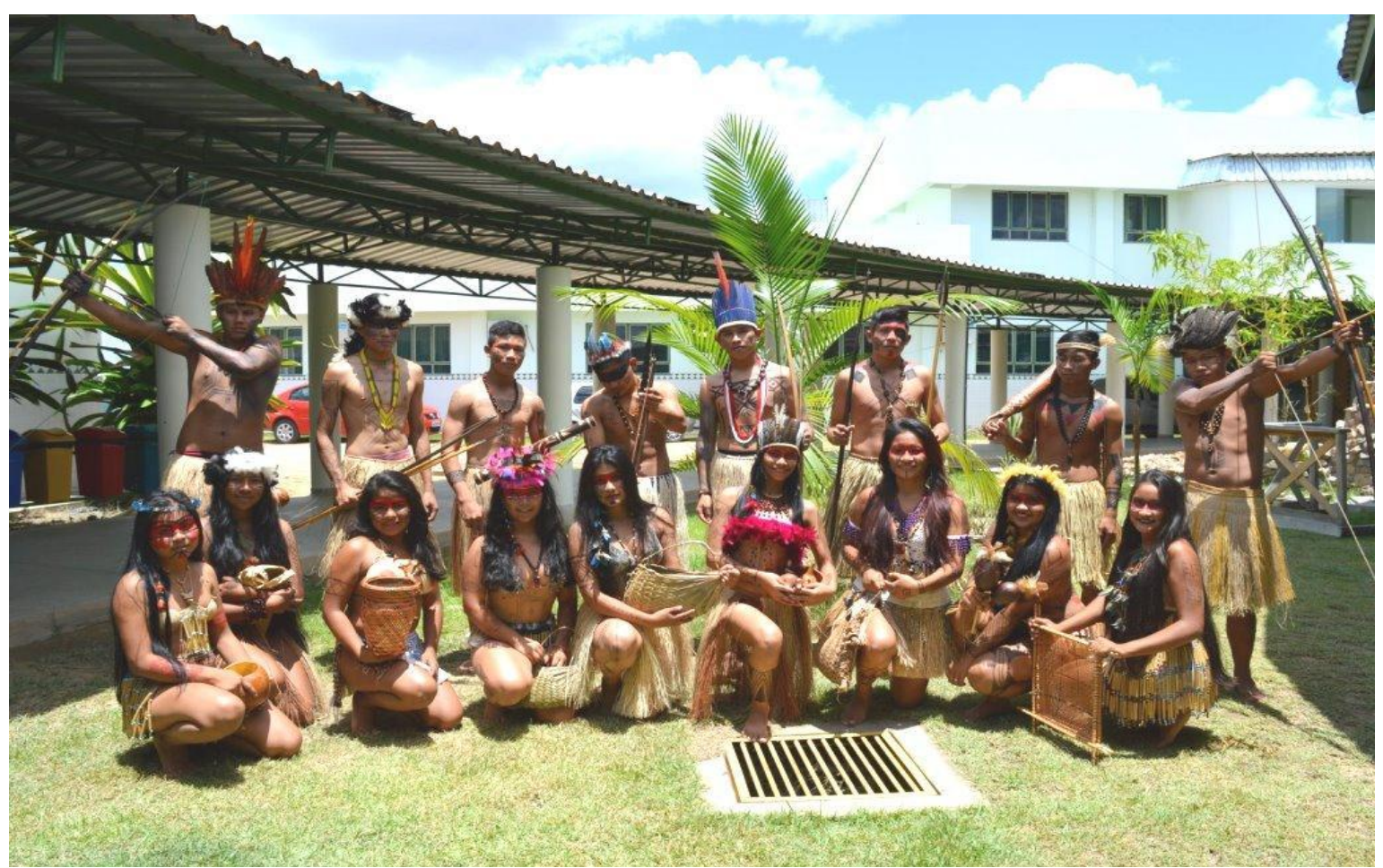

Fonte: IFRR/ASCOM.18 abr. 2019.

A confusão muito recorrente, baseada na ideia de que indígenas estão perdendo suas características originárias ao estarem se valendo dos ambientes estranhos a eles/as, desconsidera a necessidade de sobrevivência no mundo que lhes foi ofertado. "Parecer índio" pode ser, em muitos casos, uma forma de afirmar sua identidade de maneira a ser compreendido/a e respeitado/a e, em contrapartida, para eles/as não significa obrigatoriamente perda cultural. 
Muitos/as acreditam que o "verdadeiro" indígena é o que mantém determinados elementos de sua cultura, e que quando indígenas deixam suas comunidades podem "perdê-la" por estarem convivendo com não indígenas, tendo hábitos não considerados pelo senso comum como pertencentes ao universo indígena. Todavia, como nos diz Cunha (2009, p. 330): "Para atingir os seus objetivos, porém, os povos indígenas precisam se conformar às expectativas dominantes em vez de contestá-las. Precisam operar com os conhecimentos e com a cultura tais como são entendidos por outros povos, e enfrentar as contradições que isso possa gerar”. Contradições que, eventualmente, podem aparecer em seu comportamento na comunidade ou na cidade, na relação com elementos de sua "cultura" que o preconceito costuma obrigar a esconder.

Também Melo (2018, p. 27) acompanhou as trajetórias dos indígenas e suas organizações em Boa Vista, onde tentavam fazer valer seus direitos constitucionais frente a racismos institucionais. Anastácio, liderança da organização Kuaikrî, que apoia indígenas em Boa Vista, afirmava em entrevista: "Se o índio não fala nada, não fala quem ele é, ele vai ficar bem. Se ele diz, ele vai ter discriminação". Sendo assim, muitas vezes a estratégia de ocultar ou passar desapercebido em sua identidade étnica se traduz como forma de resistir e sobreviver em um ambiente hostil, e não de negar sua identidade.

Lasmar (2005) também discute essa insistência em identificar os indígenas. A autora constata a incoerência de associar o "índio" a um modelo tradicional construído por nossa sociedade ocidental colonizadora, para a qual "uma pessoa pode ser reconhecida como ‘indígena' à medida que vive com índios e como índio”.

A cultura precisa ser entendida levando-se em conta as transformações que sofre nas relações que mantém com os seus traços tradicionais, bem como nas "fronteiras" que estabelece com eles, principalmente nas relações interétnicas, onde prevalece a diferença. Portanto, deixar de comer peixe ou tomar caxiri, frequentar ambientes citadinos ou usar celular não torna os estudantes menos indígenas. Juntando os conceitos de fronteiras, de Barth ${ }^{9}$, e de traços diacrítricos, de Carneiro da Cunha ${ }^{10}$, Cohn estabelece corretamente a situação:

Assim, o que importa não é a manutenção dos traços em si, mas da diferença que origina a identidade e que é estabelecida contextualmente por meio de traços maleáveis e flexíveis. A cultura não deve se manter em uma suposta integridade; o que deve ser preservada é sua diferenciação em relação às outras, são as fronteiras, e

9 BARTH, F. Ethnic groups and boundaries. The social organization of culture difference. Boston: Little, Brown and Company, 1969.

10 CUNHA, M. C. da. "Etnicidade: da cultura residual mas irredutível”. Antropologia do Brasil. São Paulo, Brasiliense/Edusp, 1986. 
essas são traçadas por elementos que têm origem cultural, mas são escolhidos em contexto. (COHN, 2001, p. 37)

Gersem Baniwa, tratando da importância de os povos indígenas estarem tanto na educação básica quanto na universidade, também discorda da visão de uma perda cultural por estarem afastados de suas aldeias, e conclui:

Por isso, não há distância social, cultural e espiritual entre indígenas ou comunidades
indígenas urbanas e aldeias. Quando há, é porque a distância foi artificialmente ou
ideologicamente construída. Neste sentido, perguntar ou se preocupar se o estudante
indígena, ao se formar, irá voltar à aldeia para ajudar seu povo, como uma condição
de ser indígena ou, pior ainda, para ter direito ou não, não tem sentido. (LUCIANO,
2019, p. 70)

Para o autor, nesse caso, não importa se o/a indígena formado/a voltará para a aldeia, mas em quais circunstâncias poderá manter essa conexão com sua origem: "Qualificar o indígena formado pelo seu retorno ou não à sua aldeia é uma forma de discriminação, preconceito, exotismo e exclusão".

Dessa forma, fui impulsionado para o problema que orienta esta pesquisa: compreender o que traz esses e essas jovens, e como o ensino médio é entendido para os estudantes indígenas macuxi. Este trabalho visa contribuir para o enfrentamento do problema caracterizando o que os estudantes procuram encontrar na escolarização que o Instituto Federal de Roraima Câmpus Amajari lhes oferece. São jovens que deixam suas comunidades e vão viver em alojamentos distantes de seus familiares e de sua cultura. Identificar o ponto de vista e as perspectivas desses/as estudantes quanto ao IFRR em Amajari ajudará a compreender se essa geração macuxi vê o ensino médio ao qual tem acesso como sua principal forma de profissionalização, seja para melhorar suas condições de vida nas comunidades de origem, seja para se situar na sociedade envolvente.

A escolha do grupo macuxi decorreu de um levantamento que realizei em 2017 com 104 estudantes do Ensino Médio Integrado e de uma turma de Alternância, autodeclarados indígenas. O resultado apresentou a predominância dos Macuxi, conforme a Figura 4 (p. 17).

Os Macuxi no estado de Roraima, inclusive no Câmpus Amajari, são a etnia predominante. Segundo Peres (2013, p. 17), em Roraima, compõem uma população de aproximadamente 25.400 indivíduos. Esse povo colaborou também em pesquisas anteriores (ARAÚJO, 2006; BORTOLON, 2014; CUNHA, 2004; DINIZ, 1972; FREITAS, 2003; MARTINS FILHO, 2015; MELO, 2012, 2018; SANTILLI, 1989, 1994, 2001) sobre temas de Linguística Aplicada, Antropologia e Educação Indígena, o que serviu de importante apoio para a interpretação dos dados desta pesquisa. 
Todos esses trabalhos tratam de escolas indígenas ou discutem a circulação nas áreas urbanas do estado. Nesta pesquisa, entretanto, os Macuxi foram investigados em um ambiente escolar não indígena rural, pois o IFRR é considerado em geral uma escola do campo. De acordo com o Decreto No 7.352/2010, de 4 de novembro de 2010, que dispõe sobre a política de educação do campo e o Programa Nacional de Educação na Reforma Agrária - Pronera, em seu Art. $1^{\circ}, \S 1^{\circ}$, entende-se:

I - Populações do campo: os agricultores familiares, os extrativistas, os pescadores artesanais, os ribeirinhos, os assentados e acampados da reforma agrária, os trabalhadores assalariados rurais, os quilombolas, caiçaras, os povos da floresta, os caboclos e outros que produzam suas condições materiais de existência a partir do trabalho no meio rural;

II - Escola do campo: aquela situada em área rural, conforme definida pela Fundação Instituto Brasileiro de Geografia e Estatística - IBGE, ou aquela situada em área urbana, desde que atenda predominantemente a populações do campo. (BRASIL, 2010)

O Câmpus Amajari, CAM, fica em uma área considerada rural e toda a sua estrutura técnica é voltada para aulas com essa temática. Oferece cursos técnicos integrados ${ }^{11}$ de Agropecuária e Aquicultura. Sobre esse câmpus há dissertações realizadas a partir de 2012, de autoria de servidores/as da instituição, alguns dos quais não estão mais trabalhando na região.

$\mathrm{O}$ atendimento de comunidade indígena com educação profissional foi tratado por Silva (2012), que apresentou alternativas curriculares e metodológicas de ensino a serem implantadas nos cursos oferecidos pelo Câmpus Amajari. A autora investigou as concepções de educação indígena presentes no câmpus, salientando a Educação a Distância, a Alternância, a Itinerância e também a integração entre estas, "destacando a possibilidade de atendimento com a alternância de forma invertida, isto é, o deslocamento de professores ao invés do deslocamento dos alunos" (p. 3). Souza (2013) tratou de interdisciplinaridade relacionando as propostas do curso de Agricultura que poderiam ser chamadas de interdisciplinares com as práticas da gestão e dos docentes. Seus resultados apontaram para o esforço de um grupo de professores em executar a proposta do curso, que, segundo ela, buscava "garantir ao educando o papel de protagonista no processo de construção de seu conhecimento e de sua formação profissional” (p. 8). Entretanto, indicaram uma lacuna entre o currículo escolar e a realidade dos alunos, pertencentes, em sua maioria, às etnias macuxi e wapichana.

11 As modalidades de ensino ofertadas no Câmpus Amajari do IFRR são: cursos técnicos integrados ao ensino médio, nos quais são ministradas disciplinas técnicas e básicas do ensino médio; cursos técnicos subsequentes, para quem concluiu o ensino médio e faz apenas as disciplinas técnicas; cursos concomitantes, com aulas em outra unidade de ensino médio regular, em regime de alternância, prevendo-se 15 dias no IFRR e 15 dias na comunidade; e educação de jovens e adultos (EJA). 
No mesmo ano de 2013, o diretor-geral do Câmpus Amajari, ainda como pro tempore, também apresentava sua dissertação (BARROS, 2013) sobre o regime de alternância na comunidade indígena do Guariba. No ano da fundação do câmpus, Lopes (2015) analisou a educação profissionalizante destacando a presença dos povos indígenas na instituição. Ela produziu um panorama esclarecedor daquele momento, quando ainda não havia os cursos de nível médio que se estruturaram, tampouco o curso superior em Aquicultura. Mas já sinalizava problemas que permaneceram, como as tensões entre as/os alunas/os indígenas e não indígenas, e a dificuldade de alguns docentes de entenderem a diversidade cultural da região.

Sobre evasão e fracasso escolar, Lopes (2017) fez entrevistas com alunos(as) e um professor a respeito das dificuldades que os/as discentes indígenas enfrentavam para concluir os cursos de ensino médio integrados de Agropecuária e Aquicultura. Utilizou dados do Plano estratégico institucional para a permanência e êxito dos estudantes do IFRR - Câmpus Amajari, de 2016, bem como subsídios da Coordenação de Registros Acadêmicos (Cores), contabilizando um total de 512 matrículas em 2016, sendo 297 na modalidade presencial e 215 na modalidade Ensino a Distância (EaD). Desse total, 272 se autodeclaravam indígenas (p. 5354). Sua pesquisa apontou altos índices de evasão e principalmente reprovação entre 2008 e 2016 (média de 31\% de reprovação, de 2011 a 2015). Aquela pesquisa apontou como possíveis causas de evasão no CAM "problemas com a logística de transporte, não identificação com os cursos ofertados, jornada diária desgastante, dificuldade em acompanhar o ritmo dos cursos, problemas de relacionamento com os professores e, a nosso ver, o mais importante, a reprovação" (p. 97).

A valorização das culturas musicais indígenas e a formação de professores para o ensino da música foi abordada por Lima (2018), professor de música da instituição. Foi o primeiro trabalho servindo-se de entrevistas com os/as discentes indígenas que frequentam o CAM. Ele sublinhou a distância entre a formação de professores de música e a realidade do estado, de forte influência musical indígena. Apresentou projetos de extensão que desenvolveu no CAM, onde alunos/as venezuelanos/as indígenas e não indígenas interagiam durante a aprendizagem de músicas indígenas.

Entrevistas com docentes também foram empregadas por Lobo (2018), pedagoga do CAM, tratando do planejamento pedagógico interdisciplinar e das dificuldades de entendimento e execução dos projetos da instituição. Recorrendo também a docentes, Souza (2018) discutiu a importância da formação continuada. Outra pedagoga do CAM, J. Oliveira (2019), abordou gestão pedagógica e interculturalidade, evidenciando a dificuldade de docentes, coordenadores(as), pedagogos(as) e diretores(as) de ensino para entenderem esse conceito. 
Com exceção de Lopes (2015) e Lopes (2017), essas pesquisas foram dissertações apresentadas no Programa de Pós-Graduação em Educação Agrícola da Universidade Federal Rural do Rio de Janeiro, que mantém convênio com o IFRR. Silva (2012), Lopes (2015), Lopes (2017) e Lima (2018) têm como foco os/as discentes e suas dificuldades, sendo indígenas ou venezuelanos/as, para concluírem seus cursos na instituição. As demais cinco dissertações têm foco nos/as servidores/as ou em documentos institucionais para analisarem questões pedagógicas do CAM. O conjunto revela a preocupação em ofertar formação para o corpo docente e demais servidores/as da instituição e possibilita uma série de reflexões acerca da unidade escolar.

A temática de alunos/as indígenas em escolas não indígenas é muito instigante em Dickel (2013), que aborda as relações interculturais ${ }^{12}$ entre indígenas kaingang da Aldeia Por Fi, no município de São Leopoldo, Rio Grande do Sul, estudantes de uma escola não indígena estadual, com seus encontros e desencontros. A autora observou a aproximação de grande parte dos/as professores/as da escola não indígena, a partir de uma visão marcadamente exótica dos Kaingang e uma aceitação das diferenças entre os estudantes, sugerindo uma dificuldade maior para a instituição e seus representantes conseguirem desenvolver as relações interculturais do que para os/as jovens estudantes.

Em uma situação mais conflituosa, Resende (2003) descreve a situação dos Xavante em Campinápolis, Mato Grosso. Por não disporem de ensino fundamental II em sua TI, sofrem todos os tipos de preconceito indo estudar na cidade. Diante dos inúmeros conflitos ocorridos entre o povo xavante e a população de Campinápolis, que se sente ameaçada pela grande quantidade de indígenas que residem na região, o autor destacou uma visão estereotipada e racista sobre os/as indígenas que tentam cursar o ensino fundamental II e o médio, havendo altas taxas de evasão e repetência.

Santos e Secchi (2013) acompanharam as crianças arara e gavião de Rondônia, no município de Ji-Paraná. Descreveram as dificuldades que esses povos indígenas sofriam em contexto urbano e como suas crianças eram estimuladas a negligenciar seu pertencimento étnico para não serem objeto de preconceitos.

Esses trabalhos buscaram retratar lugares cheios de conflitos e experiências interculturais que envolvem alunos/as indígenas em instituições escolares não indígenas.

12 Entendo interculturalidade da maneira como o faz o baniwa Gersem Luciano (2019, p. 60), ou seja, como uma forma de "abrir caminhos para o reconhecimento e reposição dos sujeitos colonizados, subalternizados, subjugados, silenciados, dominados e alijados de suas autonomias societárias e cosmológicas a uma posição de diálogo, de interação, de coexistência e convivência dialética". 
Entretanto, a quantidade de obras sobre esse tema é muito pequena, principalmente se o objetivo for o ensino médio. Atualmente, as dissertações e teses que retratam alunos/as indígenas no ensino superior têm aumentado, possibilitando um diálogo profícuo sobre a presença de estudantes indígenas em ambientes escolares não indígenas. 


\title{
Caminhos e descaminhos
}

Após o constante diálogo com meu orientador e as aulas na pós-graduação da Antropologia, da Faculdade de Educação e do Instituto de Estudos Brasileiros (IEB), avistei alguns caminhos abertos pelo trabalho de campo. O fato de eu não ser antropólogo e nem ser pedagogo de formação, mas educador de profissão, trouxe angústias sobre a minha capacidade de levar a pesquisa adiante. Teria de fazer um trabalho de campo que não seria etnográfico, pelo menos na visão da maioria dos antropólogos. Também não seria uma pesquisa totalmente educacional, pois conteria elementos muito próximos de um trabalho antropológico. Nesse sentido, foi útil o trabalho e o curso de meu orientador, cujas pesquisas com povos indígenas enxergam nas suas escolas exemplos de inovação educacional (GHANEM; ABBONIZIO, 2012; GHANEM, 2016). Igualmente a contribuição de Dal Bó (2010) sobre indígenas na Universidade Federal de São Carlos, pois me identifiquei com os dilemas que ambos vivenciaram.

Assim como Dal Bó, percebi que estava em um tipo de situação etnográfica invertida. Normalmente, o antropólogo se desloca ao local de campo, torna-se um estranho e precisa se adaptar ao ambiente e às regras do lugar em que está se inserindo para conseguir realizar sua investigação. No entanto, na minha pesquisa e na daquela autora,

\begin{abstract}
ocorreu, de certa maneira, uma inversão do que geralmente acontece nas pesquisas de campo, pois não foi necessário que eu descobrisse o lugar, que eu me inserisse em um espaço e me adaptasse a ele; todavia, quem passou por isso foram os índios, que saíram de suas aldeias, foram morar longe de casa, estabeleceram relações com nãoíndios e com índios de outras etnias, inclusive nas moradias estudantis. Enfim, conviveram - e convivem - em um universo que pode lhes ser totalmente novo, mas que, ao contrário, para mim é conhecido. (2010, p. 11)
\end{abstract}

Eu tinha necessidade de evidenciar como os estudantes enxergavam a instituição e o que esta representava para eles, tentar ouvi-los para captar as razões que os motivavam a estudar em uma escola não indígena. Os trabalhos feitos até então haviam se centrado na instituição e acabavam se detendo em documentos oficiais da unidade escolar ou em depoimentos dos servidores/as, principalmente professores/as, com vistas a alcançarem uma interpretação do CAM. Entretanto, parecia necessário explicitar também o ângulo do/a discente, pois a organização escolar deveria ser destinada a ele e ela. São as/os estudantes a viga mestra da unidade escolar, e seus interesses deveriam ser mais compreendidos e ouvidos.

Um bom sistema educacional é pensado desde (e deve responder prioritária e fundamentalmente às) necessidades de quem aprende: crianças, jovens e adultos. $\mathrm{O}$ sistema em seu conjunto, e cada instituição educacional em particular, deve adaptarse aos alunos, e não o inverso. Tal adaptação inclui decisões em torno do para quê, do onde, do quando, do o quê e do como na educação e na aprendizagem. A(s) língua(s) de instrução, o currículo e a pedagogia, a administração escolar, a avaliação das 
aprendizagens, a organização do tempo e do espaço devem ser pensadas e desenhadas em primeiro lugar em função dos alunos e suas necessidades, e não daquelas dos educadores, diretores, administradores ou pais de família. Os alunos não são meros clientes, usuários ou consumidores de educação, senão destinatários principais e agentes ativos de sua própria aprendizagem. Sua participação e consulta são, pois, essenciais. (TORRES, 2003, p. 83, grifos da autora, tradução minha)

Gersem Luciano (2019, p. 25-26) também concorda com a necessidade de ouvir os/as estudantes, pois entende que "Os jovens precisam ser ouvidos para sabermos o que esperam e querem da escola indígena. Eles sabem muito bem o que querem da vida, do mundo e da escola". No caso de estudantes macuxi, a pesquisa me possibilitou olhar um universo mais complexo e sair da figura dominante de professor e pesquisador. Tentei vislumbrar como esses jovens indígenas estavam convivendo em um ambiente que causava, ao mesmo tempo, admiração e medo. Assim, ouvi-los e encontrar seus motivos para estudarem na instituição e o que estavam e estão fazendo com essa experiência seria fundamental para sugerir opções de melhorias nas condições que esses/as estudantes vivenciavam.

Entretanto, o processo de entendimento da realidade desses povos indígenas, em especial os macuxi e os estudantes dessa etnia que frequentavam o CAM, foi se dando também durante a elaboração desta tese. O que inicialmente era uma curiosidade sobre a motivação da presença dos estudantes indígenas do Câmpus Amajari foi se tornando uma nova reflexão. Reposicionei minha concepção de educação escolar e enxerguei os Macuxi como potenciais sujeitos de seus destinos, não mais circunscrevendo sua situação e objetivos a respeito de seus futuros acadêmicos e pessoais às expectativas de lideranças de suas comunidades ou de seus/suas responsáveis legais. Mais do que saber por que queriam estar no CAM, preocupei-me também em entender o que estavam fazendo com sua escolarização enquanto estavam na instituição.

\section{Procedimentos de pesquisa}

Foram realizadas 77 entrevistas e conversas, envolvendo 22 estudantes macuxi, 11 alunas/os de escolas indígenas de Amajari e da região do Surumu, 4 gestores/as de escolas indígenas, 20 alunos/as egressos dos cursos de Agropecuária e Aquicultura do CAM, 14 servidores/as, 4 pais e mães de alunos e 6 lideranças indígenas de comunidades das quais se originam as/os discentes.

O lugar da pesquisa de campo era o meu local de trabalho, os envolvidos eram meus/minhas colegas e eu havia lecionado na instituição, fatos que tornaram a coleta de dados 
mais fácil de ser realizada, mesmo levando em conta as possíveis alterações de julgamento que a proximidade com os envolvidos poderia causar.

Dificuldades como ter que me inserir no meio, ou a minha presença interferir no ambiente, não aconteceram, pois eu já fazia parte e era perfeitamente conhecido por todas/os envolvidas/os na pesquisa. Sendo assim, optei pela observação participante nas conversas com os servidores/as, processo pelo qual se mantém a presença do observador em uma situação social com o objetivo de realizar uma investigação científica (SCHWARTZ; SCHWARTZ, $1955^{13}$ apud CICOUREL, 1975, p. 118-119). Isso possibilita graus diversos de integração no grupo observado e de sistematização dos procedimentos de coleta de informação, segundo os objetivos estabelecidos pelo investigador, e maior flexibilidade para com fenômenos ou grupos de reduzida dimensão.

Adotei, então, uma prática menos formal na qual as tradicionais entrevistas são substituídas por conversas espontâneas em encontros situados (SPINK, 2008, p. 72). Nos meses de setembro de 2017, fevereiro-março e novembro de 2018, março-abril de 2019 e janeirofevereiro de 2020, realizei trabalhos de campo no qual utilizei esses tipos de conversas. Algumas foram gravadas e outras, dependendo da situação, eram diálogos descontraídos em encontros informais, posteriormente descritos em meu diário de campo.

Conversei com 14 servidores/as do câmpus: diretor-geral, diretora de ensino, pedagoga, coordenadora do curso de Agropecuária, coordenador do curso de alternância em Agropecuária, coordenador do curso de Aquicultura, coordenador de extensão, coordenadora dos cursos de ensino a distância e seis professores. Discutimos sobre os projetos voltados para os/as alunas/os indígenas e as relações destes/as com os servidores e alunas/os não indígenas. Também entrevistei 16 garotos e 6 garotas. Nesse caso, realizei entrevistas, sendo necessárias autorizações tanto da instituição quanto das/dos tuxauas ${ }^{14}$ de cada comunidade, o que reduz muito a informalidade. Mesmo estando no cotidiano dos alunos, acompanhando suas atividades por alguns períodos, era difícil dialogar tranquilamente com as/os discentes. A carga horária de aulas era muito grande e os encontros eram feitos em horários de ausência de professores/as para não atrapalhar seus momentos de descanso.

13 SCHWARTZ, Morris S.; SCHWARTZ, Charlotte Green. Problems in participant observation. American Journal of Sociology, 60, 1955.

14 Tuxauas são lideranças escolhidas e retiradas pela comunidade de acordo com regulamentos internos de cada comunidade ou etnia em Roraima. Normalmente essas lideranças são escolhidas pela sua proximidade com a sociedade envolvente e suas habilidades em negociar com os regionais. 
Em fevereiro e março de 2018, estive no câmpus no início do período letivo. Conversei com a diretora de ensino e o diretor-geral da instituição e recebi a autorização para conversar com os alunos/as sobre a pesquisa. A partir daí, tentei reunir estudantes dos anos iniciais, intermediários e finais; no entanto, essa estratégia dependia da disposição dos/as estudantes indígenas macuxi participarem.

No início de 2018, as turmas estavam com muitas ausências de professores/as, que estavam de licença médica ou haviam se removido para outra localidade em processos internos, deixando vagas para as quais ainda não tinham chegado concursados ou substitutos temporários. Aproveitei a situação para me apresentar-me às turmas e explicar os objetivos da pesquisa e o desejo de conversar sobre os temas que desenvolveria na tese. Sendo assim, essas apresentações aconteciam nas ausências dos professores. Eu podia, ao final delas, identificar os alunos/as que queriam participar das entrevistas.

A partir do interesse de algumas alunas/os em participar dessas conversas, fui separando-as/os por comunidades às quais pertenciam. Visitei essas comunidades para obter as autorizações das/os respectivas/os tuxauas ${ }^{15}$ e manter conversas com essas lideranças.

As conversas com as/os alunas/os ocorreram em momentos de intervalos, em salas de aulas, bibliotecas, alojamento e sala das/dos professores sem a presença de docentes.

Visitei as comunidades Três Corações, Guariba, Surumu, Contão e Aningal para obter as autorizações e fazer as entrevistas também com as/os tuxauas. Por sugestão do antropólogo Paulo Santilli, conversei com gestores e alunos de suas respectivas escolas de ensino médio nas visitas de março/abril de 2019 e janeiro/fevereiro de 2020, e dialoguei com egressos dos cursos de ensino médio integrados do CAM que estavam cursando o superior em Aquicultura no Instituto em Amajari ou em universidades públicas ou particulares em Boa Vista.

As comunidades Três Corações, Guariba e Aningal estão em média a uma distância de 30 a $50 \mathrm{~km}$ do câmpus. As comunidades Contão e Surumu, pertencentes à Terra Indígena Raposa Serra do Sol, ficam a aproximadamente $150 \mathrm{~km}$ do câmpus. Além destas, também visitei as comunidades Uiramutã e Araçá da Serra, também na TI Raposa Serra do Sol. Nessas visitas, conversei com quatro pais de alunos das comunidades do Surumu, Aningal, Guariba e Três Corações.

15 Fui informado por gestores do CAM, conhecedores das dinâmicas de contato das comunidades, que seria mais fácil o acesso a estas e a alunos/as tendo a autorização dos líderes, que são escolhidos pela comunidade, assumindo funções de manter contato com os não indígenas e resolver problemas internos. São chamados de tuxauas em Roraima. 
Também estive com o antropólogo Maxim Repetto, da Universidade Federal de Roraima, que foi o coordenador de um relatório solicitado pelo Ministério da Educação entre 2004 e 2005 a respeito das demandas das comunidades indígenas de Roraima em relação ao ensino médio. Algumas conversas foram registradas em gravações e a maioria em um diário de campo, elaborado durante as visitas de fevereiro, março e novembro de 2018. Retornei em março e abril de 2019. Em novembro de 2018, fui convidado para um evento na Universidade Federal de Roraima, em Boa Vista, onde ministrei um minicurso, participei de uma mesa redonda sobre diversidade cultural com professores locais e organizei um Grupo de Trabalho para discutir pesquisas a respeito de representações dos povos indígenas no Brasil.

Em janeiro e fevereiro de 2020, retornei ao Instituto, onde realizei novas conversas com egressos e com discentes de escolas indígenas, acompanhei os trabalhos de início de ano letivo e obtive dados atualizados da composição discente do CAM.

Examinei documentos referentes ao IFRR, entre os quais o Plano de Desenvolvimento Institucional (PDI), o Projeto de Alternância e o Plano Estratégico Institucional para a Permanência e Êxito dos Estudantes do IFRR Câmpus Amajari.

Logo após esse período, houve o início da pandemia de covid-19, e as aulas presenciais foram interrompidas no câmpus, assim como nas escolas do estado de Roraima. Entre os dias 18 de março e 31 de agosto de 2020, o calendário acadêmico foi suspenso. Estava previsto o retorno, em sistema de ensino não presencial, a partir de $1^{\circ}$ de setembro.

Os professores deveriam produzir apostilas para as turmas de $3^{\circ}$ ano do ensino médio técnico em Agropecuária e Aquicultura, e o material seria entregue aos/às estudantes por servidores/as da instituição.

Inicialmente, notei uma grande valorização da instituição entre as/os estudantes, seus familiares e lideranças. Esses/as jovens veem uma possibilidade de melhoria das condições de vida com o aprendizado que estão obtendo e, ao contrário do desejo dos pais e lideranças, poucos delas/es pretendem regressar à comunidade ou continuar os estudos nas áreas de Agropecuária ou Aquicultura. Almejam, geralmente, cursos como Veterinária, Medicina, Direito ou Enfermagem.

As/os estudantes relataram um esforço grande para chegar ao câmpus e dificuldades em se adaptar a um ensino profissionalizante e técnico que as/os ocupa durante todo o dia. Também descreveram situações de discriminação quanto às suas origens indígenas por parte de colegas não indígenas. No entanto, a maioria não fez muitas críticas à instituição. Viam, de modo geral, o Instituto como uma boa oportunidade para terem um estudo melhor do que teriam em suas comunidades, sobre as quais relatam falta de professores e de estrutura física das escolas de 
ensino médio. Assim, as entrevistas efetuadas e as pesquisas desenvolvidas principalmente por Repetto (2006 e 2008), Bortolon (2014) e Freitas (2004) levam à proposta para responder as duas perguntas norteadoras do projeto: por que esses estudantes macuxi se deslocam ao CAM e o que buscam no ensino médio do IFRR Câmpus Amajari?

Nossa hipótese para a primeira questão seria que o desejo dos/as familiares, dos/as amigos/as e das lideranças de suas respectivas comunidades de que esses e essas jovens adquirissem uma formação técnica que pudesse auxiliar em projetos nas comunidades os/as levaria a optar pela ida ao Câmpus Amajari, fator associado à situação de fragilidade do ensino nas escolas indígenas situadas nas localidades desses e dessas estudantes. Produz-se uma visão negativa sobre essas unidades escolares e, em contrapartida, uma visão positiva sobre o IFRR, onde estudantes, familiares e lideranças depositam as perspectivas de que os/as jovens adquiram uma profissão e, assim, sejam absorvidos mais facilmente pelo mercado de trabalho urbano ou nas suas comunidades.

A segunda hipótese, sobre o que buscam na instituição, estaria relacionada majoritariamente à perspectiva de ingressarem nas universidades públicas e privadas do estado; consideram a escolarização do CAM mais apropriada para esse objetivo, em oposição às dificuldades que as escolas indígenas apresentam.

\section{Estrutura da tese}

O primeiro capítulo da tese apresenta a discussão da literatura especializada sobre o tema de alunos indígenas em escolas não indígenas, assim como apresenta a região do município de Amajari. Nessa parte, informo sobre as comunidades que visitei e as conversas que mantive com os/as tuxauas dos lugares a que pertencem os/as alunos/as que participaram da pesquisa. A exposição do referencial teórico que sustenta a tese se soma ao panorama do local da pesquisa e às impressões que tive em meu trabalho de campo.

O segundo capítulo, por sua vez, trata do ensino médio profissionalizante e de sua principal proposta para os cursos presenciais: o ensino integrado. Detalho o Câmpus Amajari e sua prática pedagógica. Ainda nesse capítulo reflito sobre a educação escolar indígena e faço um histórico da implantação da escolarização indígena em Roraima. Abordo o tema dirigindome à influência das escolas indígenas consideradas diferenciadas sobre os alunos/as que chegam ao câmpus, e como isso os afeta no processo de aprendizagem.

O terceiro capítulo conceitua juventude no contexto atual e constrói uma abordagem das juventudes macuxi de Roraima. Está composto pelas informações resultantes das entrevistas e 
conversas, refletindo sobre a expectativa em torno da juventude indígena, a dicotomia aldeia/cidade e seus conflitos de pertencimento étnico. Por fim, respondo à pergunta norteadora da pesquisa: o que as/os estudantes indígenas macuxi buscam na instituição?

$\mathrm{Na}$ Conclusão, retomo as duas hipóteses focalizadas na pesquisa, segundo as quais a ida ao IFRR Câmpus Amajari se deve a influências de familiares e das lideranças que percebem a necessidade de melhorar as condições de sobrevivência nas aldeias ou comunidades macuxi, por meio do domínio de conhecimentos ligados à melhoria nas condições de manejo da agricultura, pecuária ou aquicultura. Entretanto esse desejo entra em conflito com o interesse dos e das jovens macuxi, que revelaram uma visão negativa sobre as escolas indígenas em suas comunidades. Assim, a segunda hipótese subordina a procura da escolarização ofertada pelo Câmpus Amajari à busca desses/as estudantes por melhores condições para a disputa de vagas nos cursos superiores disponíveis em Boa Vista e em outros municípios do estado. 


\section{CAPÍTULO 1. A PESQUISA, AMAJARI E OS MACUXI}

Minha intenção inicial era pesquisar as etnias presentes no Câmpus Amajari e suas representações sobre o Instituto Federal em Roraima. Entretanto, após conversas com meu orientador e leituras sobre cultura e sobre educação escolar indígena, preferi me concentrar em uma etnia, pois as complexidades dos povos originários são muito grandes, suas visões de mundo são muito específicas e seria inviável para uma pesquisa nas condições disponíveis abarcar as quatro etnias existentes no câmpus.

Minha pesquisa não é sobre uma escola indígena e se refere a uma situação comum em várias regiões do Brasil, especialmente nas regiões Norte e Centro-Oeste: a frequência de indígenas em instituições escolares não indígenas. De acordo com dados do Censo de 2010 do Instituto Brasileiro de Geografia e Estatística (IBGE), dos 817.963 indígenas existentes no Brasil, 315.180 residem em áreas urbanas (OLIVEIRA, N., 2014, p. 236). As chances de que muitos deles não frequentem escolas indígenas são muito altas, o que caracterizaria um percentual importante de integrantes de povos originários em constante convivência com a sociedade envolvente. O Brasil, lembra Melo (2018, p. 16), é o terceiro país na América Latina em populações indígenas vivendo em áreas urbanas, ficando atrás apenas do Chile e da Bolívia.

Gersem Baniwa Luciano (2019, p. 19) aponta os aspectos negativos e positivos do que chama de "êxodo indígena". Classifica esse movimento para as áreas urbanas como um problema pois ocasiona o esvaziamento das aldeias, tornando principalmente os serviços de saúde e educação mais caros por habitante. Além disso, o deslocamento submete os jovens e as famílias - o autor centraliza seus comentários em Manaus - a "todo tipo de exclusão, marginalização, preconceito, discriminação e racismo". No entanto, destaca outras consequências, como o fortalecimento das organizações indígenas ali e uma qualificação maior na formação desses líderes, que acabam se destacando nos espaços urbanos.

\footnotetext{
Neste caso em particular percebe-se que, enquanto as aldeias localizadas em terras indígenas patinam fragilizadas em suas mobilizações e lutas por seus direitos, as comunidades indígenas urbanas estão em franco processo gradativo de empoderamento mobilizativo, organizativo e reivindicativo. E não é só isso. É nelas e delas que percebemos uma nova consciência e força na luta pela valorização de suas culturas, pinturas, músicas, danças, línguas e afirmação de suas identidades étnicas. São verdadeiros processos de pesquisa, resgate, (re) aprendizagens e (re) construções culturais, identitárias e espirituais. (2019, p. 19-20)
}

A bibliografia sobre o tema é extensa (ALBUQUERQUE, 2011; ALBUQUERQUE; NAKASHIMA, 2012; ANDRELLO, 2004, 2006; BERNAL, 2009; BRAYNER, 2013; LASMAR, 2005; MACHADO, 2008; MELO, 2009; MELO, 2012, 2018; MOTA, 2000), englobando desde pesquisas com populações que vivem em municípios próximos às suas 
aldeias até residentes em grandes capitais, bem como em aldeias "dentro do espaço urbano". As obras mais recentes abandonaram a tendência de opor aldeia à cidade em uma relação de dominação, passando a abordar as situações como um contínuo (NUNES, 2010, p. 22).

O trabalho de Lasmar (2005) sobre os indígenas do Alto Rio Negro, por exemplo, parte de uma tentativa de entender o envolvimento de mulheres indígenas com não índios e a extensão da aldeia em áreas urbanizadas. A inserção dessas pessoas de etnias variadas que se deslocam para cidades como São Gabriel da Cachoeira (AM) tem como motivação, entre outros tópicos, o desejo de escolarização.

\begin{abstract}
À medida que se ampliou a influência salesiana, cresceu a importância da formação escolar completa, e o resultado foi que grande parte das famílias passou a não medir esforços para ver um filho completar os estudos e conseguir um trabalho assalariado. Entre as atividades que os índios plenamente escolarizados têm oportunidade de exercer, destacam-se as de professor e auxiliar de enfermagem. A valorização dessas duas profissões, que se relacionam, respectivamente, com a transmissão do saber acumulado e a cura e prevenção das doenças, parece indicar que estamos no caminho certo ao associar a busca por escolarização com uma concepção de conhecimento que conecta de forma conspícua o saber e poder de operar transformações. (cap. 5, n.p)
\end{abstract}

Além da região amazônica, essa relação com a educação escolar também é apontada por pesquisadores nas cidades de Curitiba e Campo Grande (COMISSÃO PRÓ-ÍNDIO DE SÃO PAULO; CENTRO GASPAR GARCIA DE DIREITOS HUMANOS, 2013, p. 30).

Organizações indígenas por todo o país também fazem seus próprios levantamentos e publicações, isoladamente ou com parcerias, a respeito das populações indígenas que residem em espaços urbanos (OLIVEIRA, 2010). Vale destacar o Conselho Indígena de Roraima (CIR), a Organização de Índios da Cidade (Odic), a Associação Indígena Kapói e a Kuaikrî Associação Indígena. Com atuação em Boa Vista, apresentam diferentes estratégias como forma de pressionar o Estado pelo reconhecimento do pertencimento étnico (MELO, 2018). Outra ainda é a Associação Indígena SOS Comunidade Indígena Pankararu (Soscip), atuante em São Paulo desde 1994.

O antropólogo Roberto Cardoso de Oliveira é identificado por Melo (2018, p. 18) como o autor que inicia, com $O$ índio e o mundo dos brancos: a situação dos Tikuna no alto Solimões, lançado em 1964, a temática relativa aos povos indígenas em áreas urbanas e consolida o tema em 1968, quando publica Urbanização e tribalismo: a integração dos índios Terena. Melo aponta Oliveira como um importante referencial, pois, além de suas publicações a partir da década de 1980, seus orientandos nos programas de mestrado e doutorado também realizaram pesquisas e dissertações sobre a problemática de indígenas vivendo em cidades.

Melo também destaca a obra de Edgard de Assis Carvalho, publicada em 1979, intitulada As alternativas dos vencidos: índios Terena no estado de São Paulo, fruto de sua tese 
de doutorado. A mesma Melo aponta os anos de 2000 em diante como um período rico em publicações voltadas ao tema. Relaciona algumas categorias de análise que considera importantes, como: as relações sociais transfronteiriças, ou seja, entre aldeia e cidade; os fluxos migratórios; as políticas públicas para indígenas da cidade; diagnósticos sobre a situação e modos de vida na cidade; territorialidades; etnicidade indígena na cidade; questões de identidades multiétnicas na Amazônia brasileira; percepções dos indígenas sobre a cidade; e ensino de línguas indígenas na cidade (2018, p. 18-19).

Em Boa Vista, a autora identifica as primeiras publicações a partir da década de 1990, com dois trabalhos: a obra Achados ou perdidos: A imigração indígena em Boa Vista, de Ferri (1990), e o relatório intitulado Trabalho e marginalização indígena em Boa Vista em 1999.

A partir do ano 2000 há um aumento no número de publicações a esse respeito no âmbito roraimense. A historiadora Azenate Braz, em 2003, conclui sua dissertação de mestrado (Relações interculturais: a vivência do índio Macuxi em Boa Vista) e, em 2010, publica o capítulo "Possibilidades de inclusão na história: índios Macuxi da cidade", no livro História e diversidade: política, educação, gênero e etnia em Roraima.

De acordo com Melo (2018), o ano de 2016 recebe a publicação de Moradores da Maloca Grande (LIMA; CIRINO, 2016), que "reúne a produção mais recente de pesquisadores indígenas e não-indígenas sobre dados etnográficos obtidos com as lideranças indígenas da cidade de Boa Vista”. Dessa obra, Melo destaca a contribuição de Lima e Souza (2016), que apresentam, no "Mapeamento social dos indígenas de Boa Vista (RR)", reflexões resultantes do projeto Violação dos Direitos dos Indígenas de Boa Vista, demandado pela Odic, cuja culminância foi o mapeamento social dos povos indígenas da cidade.

A autora também salienta o artigo de Rodrigues (2016) “Nem indígena nem 'branco’: o dilema jurídico dos indígenas na cidade", que enfatiza "que os aplicadores do Direito não acompanham as mudanças sociais provocadas pela pressão de movimentos indígenas, em especial no contexto urbano, ocasionando um tratamento inadequado às necessidades daqueles que residem em cidades". Nascimento (2016), por sua vez, relacionou o discurso de uma professora da rede estadual de ensino de Roraima à construção de identidades indígenas no ambiente escolar.

A própria tese de doutorado de Melo (2018) destacou as dificuldades que os indígenas residentes na cidade de Boa Vista vivenciavam ao terem sua identidade étnica recusada pelos agentes estatais devido ao fato de residirem fora das suas aldeias, sendo vítimas de racismos institucionais e tendo seus direitos constitucionais negados. 


\subsection{A temática da educação escolar indígena}

Os primeiros trabalhos que abordam a educação escolar indígena como objeto de pesquisa datam do final dos anos 1970 e início dos anos 1980. A primeira publicação indicada

por Capacla (1995) trata da escolarização de etnias da região Sul, como estas estariam em estado de submissão e dominação com relação aos órgãos governamentais e aos sistemas de produção e consumo (SANTOS, 1975). Segundo Grupioni (2003), são pioneiros também Tsupal (1978) e Assis (1981). A temática viria a ganhar maior expressão a partir dos anos 1990, principalmente com Cunha (1990), Maher (1990) e Ferreira (1992).

Indígenas começaram a produzir dentro da temática (TAUKANE, 1996; REZENDE, 2003), numa tendência que teve continuidade em institutos de Educação, Antropologia e Linguística. Também são encontrados trabalhos nas áreas de Artes Plásticas, Geografia, História, Letras e Matemática. A produção foi impulsionada pela mobilização das populações indígenas a partir da década de 1970, reivindicando seus direitos básicos tais como as demarcações de terras e demandas nas áreas de saúde e educação, sobretudo com as transformações advindas da Constituição de 1988, que reconhece direitos dos povos originários e sua afirmação como sujeitos coletivos com legitimidade para colocar demandas judiciais sem intermediários. Consequentemente, a escolarização ampliou sua importância política.

Direitos específicos e cidadania plural indicam que os povos indígenas têm um tratamento jurídico diferenciado. Por exemplo, é concedido a eles o direito de terra coletiva suficiente para a sua reprodução física, cultural e espiritual assim como a opção de educação escolar diferenciada baseada nos seus próprios processos de ensino, aprendizagem e produção, reprodução e distribuição de conhecimentos (LUCIANO, 2006, p. 36).

Vários trabalhos realizaram o levantamento da literatura sobre a educação escolar indígena (CAPACLA, 1995; CUNHA, 1990; GRUPIONI, 2003, 2008; LUCIANO, 2011; PALADINO, 2001), como também daquela sobre a relação de antropólogos com esse campo (CAVALCANTI, 1999; SILVA, 1997 1999; TASSINARI, 1997). As pesquisas pioneiras discorriam de maneira central sobre as implicações da presença de escolas em aldeias com demarcações em zonas rurais, na maioria das vezes baseadas em estudos de casos e com abordagens temáticas comuns. Poucas lidavam, porém, com as "políticas e práticas educativas em nível nacional" (PALADINO, 2001, p. 21).

A “questão indígena nas salas de aula", por sua vez, começou a emergir no campo antropológico brasileiro em análises sobre materiais didáticos (SILVA; GRUPIONI, 1995; GRUPIONI, 1996; GOBBI, 2006), bem como no debate sobre a utilização do conjunto de 
conceituações e metodologias ${ }^{16}$ antropológicas por professores em suas práticas pedagógicas, e no desafio de transmitir noções de cultura e sociedade, na Antropologia e na Sociologia, para suas/seus estudantes (FONSECA, 1999; DAUSTER, 2007; GUSMÃO, 2010; OLIVEIRA, 2011, 2014). O aumento do número de publicações reflete o espaço que a Antropologia e as Ciências Sociais ganharam dentro das exigências legislativas, pautadas pelas políticas nacionais de educação (Lei de Diretrizes e Bases da Educação Nacional, Parâmetros Curriculares Nacionais) e pelas políticas de diversidade (Lei 10.639/03 e Lei 11.645/08).

Por sua vez, a literatura sobre estudantes indígenas (geralmente de apenas uma etnia) em escolas urbanas de capitais ou de cidades interioranas descreve sua trajetória e de suas famílias a partir de suas vivências dentro das instituições urbanas. Nesse contexto, são abertos os debates sobre a relação entre as escolas e os estudantes indígenas de diversas faixas etárias, como no caso dos Xokleng, que buscam formação técnica fora da aldeia (SILVA, 2003).

Assim ocorreu quanto aos Tikuna que vivem no Rio de Janeiro e se percebem como estudantes, reconhecendo a forma como os processos de escolarização atravessam suas vidas (PALADINO, 2006). Igualmente foram abordadas as repercussões políticas advindas da presença das famílias Pankararu em escolas municipais de São Paulo (NAKASHIMA, 2009) e a presença dos Kayapó e Gorotire na cidade de Redenção, no Pará, onde esses povos tinham na educação uma forma de apreender o modo de vida dos não índios para melhor se relacionarem e "construírem alternativas para o futuro" (SOUSA, 2001, p. 264).

Conforme apontado por Paladino (2006), em sua maioria são pesquisas que procuram mostrar como as escolas realizam o trabalho de integração à sociedade envolvente, exercendo um papel de dominação da sociedade majoritária sobre a minoritária, ou destacando as dificuldades da inserção de estudantes indígenas nesses contextos urbanos.

Uma pesquisa que se assemelha ao meu trabalho aborda a presença de estudantes indígenas de etnias variadas na Universidade Federal de São Carlos (UFSCar) e reflete sobre "conhecimento tradicional" e cultura (DAL BÓ, 2010). Outra analisa as políticas de ação afirmativa na Ufam e na UFSCar e as produções de estudantes na pós-graduação (DAL BÓ, 2018). Essas pesquisas são muito inspiradoras porque buscaram acompanhar a vivência de estudantes em cursos de graduação e pós-graduação não indígenas. Ambientes muito parecidos com o do Câmpus Amajari para estudantes macuxi.

16 Estas publicações não tratam especificamente da presença de estudantes indígenas nas escolas das redes públicas urbanas, mas centram-se principalmente sobre como as/os professoras/es abordam a questão da diversidade cultural em sala de aula, e como os conhecimentos em Antropologia podem auxiliar nas teorias e práticas pedagógicas. 
Vale o mesmo para o trabalho de Lisboa (2017a) sobre os/as estudantes indígenas na Universidade Federal de Roraima, pois aponta experiências, motivações e dificuldades para estudarem na UFRR. A universidade tinha quase mil estudantes indígenas em um total de 7 mil, e as situações de conflitos e disputas pelos espaços do câmpus universitário eram grandes.

\subsection{Indígenas e a escola}

Antes de me deter sobre a educação escolar indígena, devo apontar minha concepção sobre educação escolar. Ghanem (2004) tratou da relação entre educação escolar e democracia, dada a importância da escola na "vida dos indivíduos, nas estratégias dos grupos sociais e na agenda dos governos”. Ele ressaltou a necessidade de mudanças no modelo de educação escolar existente, que "reduz a escola elementar a uma agência especializada em transmitir saberes considerados legítimos e indispensáveis, embora sejam em grande medida frívolos e alheios às necessidades mais vivas dos diferentes grupos sociais” (2004, p. 16). A concepção de democracia adotada é a de Touraine (1994), que não é circunscrita "ao formato de regras e contempla os conflitos sociais como constitutivos de uma ordem social e não necessariamente como destruidores dela" (GHANEM, 2004, p. 17). Assim sendo,

\footnotetext{
A democracia é uma cultura e não somente um conjunto de garantias institucionais, uma vez que é um sistema institucional que se permite a uma sociedade ser simultaneamente una e diversa. Ela é um esforço para garantir, no plano político, a combinação de duas faces da ação do sujeito - o mundo das técnicas e dos mercados e o mundo das comunidades - mantendo a unidade sempre limitada de elementos complementares sem jamais fundi-los em um princípio de orientação única. A dissociação entre o mundo da ação e o mundo do ser, entre o futuro e o passado, só pode ser enfrentada por indivíduos-sujeitos, personalidades democráticas criadas por um regime democrático que nelas se baseia. (p. 22)
}

Segundo essa definição, a democracia possui três dimensões: o respeito pelos direitos fundamentais, que acabam limitando o poder do Estado; a cidadania; e a representatividade dos dirigentes. A cidadania é conceituada como uma situação em que os cidadãos e cidadãs se sentem como tais. Além de escolherem seus governantes, também se consideram representados/as por eles/as. Se as/os governados/as se sentirem apenas membros de uma família, uma categoria profissional, etnia ou confissão religiosa, e não reivindicarem o direito de cidadania, passarão a ver seus governos como algo à parte de seu próprio mundo (GHANEM, 2004, p. 27-28).

Uma educação escolar democratizada seria uma aliada importante para o fortalecimento da democracia. A democratização do sistema escolar como um todo levaria a uma alteração da 
própria natureza da organização da educação escolar, com produção de conhecimento e não apenas "transmissão de conteúdo".

No início de minha carreira no magistério, em 1994, oscilei entre as duas concepções de ensino identificadas por Ghanem (2008, p. 105-106) que retratam um profissional preocupado em "transmitir conteúdos" ou em buscar "contextualização do ensino", "partindo da realidade do aluno":

o que incluiria apreenderem características peculiares do grupo social de origem das turmas servidas pelas escolas. Entre as características consideradas mais importantes, está o vocabulário que se emprega para designar a realidade imediata, ou, como se costuma dizer, fatos da sua vida cotidiana. Não se trata de um sincero interesse em intervir em tal realidade, apenas de coletar subsídios para realizar atividades que utilizem exemplos facilmente reconhecíveis e uma linguagem intermediária pela qual seja possível fazer comunicados sobre "os conteúdos" de maneira mais imediatamente inteligível para as turmas. (p. 105)

Essa posição, apesar de franca e bem-intencionada, não consegue exprimir uma boa definição de concepção de educação escolar. Somente com alguns anos de sala de aula e muito esforço pude entender a necessidade de se buscar a terceira opção apontada por Ghanem (2008): além de uma identificação com a realidade dos/as discentes, é necessário compreender a unidade escolar como parte da comunidade onde está inserida e isso "implicaria abandonar o modelo de educação como ensino para dar lugar, por exemplo, à realização de uma educação como prática refletida e conjunta de educandos(as) e educadores(as) em determinada realidade" (2008, p. 106). O que torna necessária uma ação conjunta envolvendo grupos, organizações sindicais, religiosas, de bairros, estatais, privadas ou não-governamentais com o intuito de possibilitar o aproveitamento dos vários saberes e aprendizagens que conduzam a um "exercício prático de cidadania e combate às desigualdades" (2008, p. 106).

Entretanto, tais ações são exceções no sistema de ensino básico e sofrem resistência dos próprios profissionais de ensino. Isso decorre da realidade a que esses profissionais são submetidos em seus ambientes de trabalho. Uma jornada de trabalho excessiva, presa a um calendário escolar pré-determinado com dias e horas articuladas, que confinam educandos/as e educadores/as em um ambiente restrito da sala de aula. Rituais burocráticos intermináveis que retiram as possibilidades de diálogo fora do ambiente escolar. Como alternativa, Ghanem vê duas possibilidades de melhorar as condições para que essas ações de cidadania e combate às desigualdades possam se efetivar no cotidiano escolar:

a) procurem aproveitar os parcos momentos de reunião em que não estão lecionando para abordar as condições em que trabalham e as concepções de educação que informam a vigência de tais condições; b) aproveitem ao máximo os próprios momentos de aula e as periódicas reuniões "de pais" para compartilhar aquela mesma abordagem com estudantes e seus familiares de modo a evidenciar que a união de uma ampla variedade de pessoas é indispensável para 
direcionar ações no sentido de decisões políticas das quais depende a radical alteração da concepção de educação que precisa predominar, por conseguinte, das formas que, hoje, assume a organização do tempo e do espaço escolar, impeditivas de uma fértil colaboração mútua entre educação formal e não-formal. (2008, p. 108)

Dessa forma, compreendo a educação escolar como forte aliada da democracia e, seguindo Ghanem (2004, p. 219), como um espaço de produção de conhecimento, no qual cada grupo, comunidade ou organização estabeleça com nitidez o conhecimento que deseja produzir, não esquecendo de tornar visíveis os conhecimentos que existem e que suportam essa produção nova. Esse enfoque em muito se assemelha ao modelo de educação escolar indígena proposta por povos originários. As escolas indígenas que procuram ser diferenciadas e multilíngues muito têm a nos ensinar sobre sua proposta inovadora, especialmente quanto à participação da comunidade local e dos profissionais da região, e à construção coletiva de calendários, planejamentos e espaço escolar.

Embora muitas vezes já se tenha marcado a distinção entre educação indígena e educação escolar indígena, convém retomá-la. A primeira diz respeito a todos os espaços nos quais os povos originários, de várias maneiras, estão aprendendo, seja oralmente com os mais velhos, seja observando os adultos em suas atividades ou durante práticas rituais. Vale ainda salientar que as formas de aprendizagem são variadas e ultrapassam o espaço da escola tanto para indígenas quanto para não índios (SILVA, 1997, p. 11-12).

Segundo Kahn (1997, p. 53) não existe "educação indígena” que caiba num modelo de escola, e os programas de escolarização costumam usar um parâmetro convencional, seja na reprodução, seja na contestação do seu modelo. Educação escolar indígena se refere, então, à prática desenvolvida no ambiente escolar, sendo assim definida por Freitas (2005, p. 73):

O acréscimo do termo "escolar" chama a atenção para a distinção do ensino formal em contraponto à educação informal, fortemente marcada em comunidade de tradição oral, como é o caso em questão. Como tema de pesquisa no Brasil, constitui um objeto emergente de estudo e investigação embora seja pouco explorado.

Assim, a educação escolar indígena busca, segundo Kahn (1997, p. 53), uma educação específica e diferenciada, intercultural e multilíngue ou bilíngue. A especificidade da educação escolar indígena, segundo Abbonizio (2013, p. 93), possibilitou aos indígenas um caminho para se relacionarem com os não índios.

A partir do momento em que passa a ser requisitada no âmbito de um movimento político indígena e gerida por professores e professoras indígenas, a escolarização como intervenção sobre condições de vida se torna uma alternativa concreta.

Entretanto, Luciano (2011) trata das experiências da educação escolar indígena no alto rio Negro apresentando as visões de alunos e professores/as indígenas, gestores/as e 
antropólogas/os, contrapondo-se aos posicionamentos que colocam a escola específica e diferenciada como sendo incapaz de produzir um ensino "convencional" de qualidade e mais ainda de forjar eficazmente pessoas ou cidadãos baniwa, conciliando sua posição com a de Cohn (2016, p. 319).

O grande desafio de entendimento da educação escolar indígena está, segundo Cohn (2016, p. 334), na nossa capacidade de fugir do maniqueísmo que ou supervaloriza a escola específica e diferenciada como um meio de autonomização indígena, ou "[execra] essa política pública, vendo apenas a banalização da cultura indígena e de sua aprendizagem”. Portanto, é necessário ver que

as apropriações indígenas da escola são variadas, e perpassam todo o arco que reúne os dois pólos, a indigenização revelando-se, frequentemente, dos modos mais inesperados, ou no que nos pareceria o maior de todos os tradicionalismos, enquanto a banalização pode advir do que poderiam parecer os projetos pedagógicos mais inovadores, que arriscam, ao contrário, "escolarizar" aprendizagens e conhecimentos que mantêm sua circulação e sua produção fora da escola, as quais devem ser respeitadas para que se respeitem, efetivamente, infâncias e regimes de conhecimentos indígenas. (COHN, 2016, p. 319)

É pertinente interpretar o que os próprios indígenas valorizam nessas experiências escolares para que possamos observar mais criticamente as suas comunidades e escolas. Gallois (2016, p. 509) resume essa questão colocando a contradição existente entre a "autonomia" e a “domesticação de conhecimentos" nas experiências escolares indígenas como inerente à natureza da escola. Assim sendo, ouvir estudantes indígenas seria o melhor caminho para saber por qual escola anseiam.

Cunha (2016) identifica a escolarização multicultural como uma das políticas culturais “para os índios" e, em alguns casos, "dos índios"17, pois, na escola, por intermédio do Estado, um conhecimento é privilegiado em detrimento de outros. A escola, segundo Cunha (2016, p. 14-15), "esquece que ela não é feita apenas de conteúdos e sim de procedimentos de regimes de transmissões", e que outras realidades entendem essas transmissões de formas diversas.

A escola em terras indígenas, segundo Cohn (2016), tem efeitos econômicos, gerando renda e empregos. Também traz efeitos políticos, fortalecendo e gerando lideranças, funções e cargos no Estado; além de possibilitar efeitos culturais (2016, p. 314). Porém tais alterações não são gerais, e sim específicas e localizadas. Cada comunidade afetada pela presença

17 Segundo Cunha, existem as políticas culturais para os índios e há políticas culturais dos índios. A autora distingue uma da outra. Neste meu trabalho, abordo a política cultural feita para os índios, que, em alguns momentos, até tem presença indígena, mas não é política feita pelos índios. Em alguns casos, é organizada pelo Estado ou pela sociedade civil (2016, p. 11). 
influente da escola tem seus regimes de conhecimento obrigados a dialogar ou a se confrontar com esta. Trata-se, pois, de um espaço respeitado e muitas vezes desejado por comunidades.

Gersem Baniwa identifica o modelo de escola que deseja para as comunidades indígenas, que pode ser muito aproveitável para a educação escolar de não indígenas.

\begin{abstract}
A outra questão é: que escola os índios almejam e sonham ter? Ao que os índios respondem: escola do jeito indígena. Essa questão desafia a pensar uma escola indígena atraente para as crianças e jovens indígenas. As atividades escolares de ensinoaprendizagem precisam ser desenvolvidas com prazer, alegria e satisfação das crianças e jovens e não como obrigação, dever, sacrifício, sofrimento. Para isso é necessário que a escola ofereça respostas, possibilidades e oportunidades concretas, objetivas e coerentes para as suas aspirações e projetos pessoais e coletivos, por meio de suas estruturas pedagógicas, curriculares, metodologias, regimentos e calendários. A Escola Indígena não deve se preocupar tanto com as notas dos alunos mas com o alcance de seus sonhos e seus projetos pessoais e coletivos. Propiciar-lhes oportunidades para ir longe, o mais possível, em suas buscas e sonhos existenciais. O propósito da escola indígena deve ser formar pessoas e coletividades humanas vivendo em um mundo melhor. (LUCIANO, 2019, p. 25)
\end{abstract}

Nessa perspectiva, cabe considerar a escola como espaço de contato, onde as "diferenças interétnicas emergem e adquirem novos contornos" (TASSINARI, 2001, p. 56). Pode-se também entender a escola como um espaço de diálogo, que entrecruza diversos caminhos formando uma "rede de significados". Seguindo essa abordagem, Tassinari (2001, p. 50) argumenta que

não é possível definir a escola como uma instituição totalmente alheia. Por outro lado, também não se pode compreendê-la como completamente inserida na cultura e no modo de vida indígena. Ela é como uma porta aberta para outras tradições de conhecimentos, por onde entram novidades que são usadas e compreendidas de formas variadas.

Manfrói (2002, p. 49) aponta que “o papel da escola permanece perpassado pelo conflito entre as perspectivas dos indígenas e as perspectivas desenhadas e impostas pelo entorno regional". Com efeito, trata-se de entender a escola a partir dos sentidos que as/os índias/os lhe atribuem. Estar em uma escola não indígena, onde o que se aprende e o que se troca culturalmente é feito sob uma ótica homogeneizante, na qual se consideram determinados "conteúdos" como universalmente necessários, acaba entrando em conflito com o ideário de uma escola multicultural. Contudo, para algumas comunidades em Roraima nas quais há escolas indígenas, a opção pela escola não indígena se aproxima da satisfação de uma necessidade local e específica, que as escolas próprias não conseguem suprir. Nas conversas com as/os estudantes macuxi, fica evidente o entendimento segundo o qual os conhecimentos que eles imaginam que vão adquirir no Instituto lhes serão mais úteis e necessários para o momento atual de suas vidas.

Em suma, o conjunto de obras mencionado possibilita enxergar a necessidade de observar o olhar que o indígena tem sobre a escola e a sua necessidade mais prática e óbvia 
para sua sobrevivência. Mesmo sendo desejável que prevaleça a educação diferenciada e multiétnica, que valoriza a cultura e a língua originária, não se pode fechar os olhos ao desejo desses povos de satisfazerem suas necessidades mais atuais e essenciais para sobreviverem em uma Roraima muitas vezes preconceituosa, que retirou deles quase todas as suas terras férteis, deixando apenas simulacros de direitos e modelos de organização muito próximos dos não índios. Destaco que, nas conversas com as/os estudantes e tuxauas, notei a procura de uma formação mais voltada a necessidades comunitárias não coincidentes com uma educação diferenciada e multiétnica.

\subsection{Amajari e suas características}

Localizado no extremo noroeste do estado de Roraima, o município de Amajari foi criado pela Lei n. ${ }^{\circ} 096$ de 1995 (MOURÃO; NASCIMENTO, 2015, p. 260) a partir das vilas Paiva e Trairão, dos assentamentos Amajari, Bom Jesus e Ametista e de 17 comunidades indígenas (CUNHA et al., 2015, p. 170). Nasceu em meio a uma disputa fundiária pela TI Raposa Serra do Sol, que também direcionou a criação dos municípios de Uiramutã e Pacaraima, ambos igualmente em terras indígenas (MOURÃO; NASCIMENTO, 2015, p. 261262), como uma tentativa do governo estadual de dificultar a demarcação (SANTILLI, 2001, p. 121-123).

O município de Amajari é um dos 15 pertencentes a Roraima. A maior parte dos 576.568 mil habitantes do estado estão na capital, que abriga 284.313 habitantes, segundo dados do $\mathrm{IBGE}^{18}$. Amajari faz divisa ao norte e ao leste com a Venezuela, ao sul com os municípios de Boa Vista e Alto Alegre e a leste com Pacaraima (SEPLAN, 2010). Além disso, está muito próximo de duas terras indígenas importantes no estado: Raposa Serra do Sol e São Marcos, o que leva alguns estudantes de suas áreas a frequentarem o Câmpus Amajari.

Assim como outros, sua fundação está relacionada ao processo de ocupação de Roraima, marcado pelas "políticas de fortificação, política de aldeamento, a instalação de fazendas do governo e a privatização destas, o papel da igreja, a pecuária, a atividade garimpeira, assentamentos agrícolas, pelotões militares de fronteira, a abertura e pavimentação de rodovias" (MOURÃO; NASCIMENTO, 2015, p. 263). O garimpo em Amajari, até a década de 1990, quando houve sua proibição, era a principal atividade econômica, tendo as vilas do Trairão e a 
serra do Tepequém como os locais de concentração dessa atividade (MICHELIN; MARTINS FILHO, 2015, p. 87). Após esse período, houve um esvaziamento populacional, seguido do aumento paulatino da ocupação do município.

As atividades econômicas se sustentam na agricultura (arroz, mandioca, milho e banana) e na pecuária, tendo destaque os rebanhos bovinos, aves, suínos, equinos e caprinos. Há também produtos animais que incluem leite, ovos e mel e, no extrativismo vegetal, madeira de tora, lenha e carvão vegetal. Há, por fim, o incremento da atividade turística na Vila do Tepequém, que reúne um conjunto de cachoeiras muito visitado e um platô de 1.022 metros de altitude (MOURÃO; NASCIMENTO, 2015, p. 266-268 e 271).

A população é formada por maioria indígena, pelas etnias macuxi, wapichana, sapará e yanomami. Esta última é pouco presente na Vila Brasil e no IFRR, sendo os Macuxi a etnia predominante na região. As principais áreas e respectivas representações indígenas do município são: Ananás, Anaro (povo wapichana), Aningal, Araçá (povos macuxi e wapichana), Cajueiro, Ouro, Ponta da Serra, Santa Inês (povo macuxi) e Yanomami (yanomami) ${ }^{19}$ (SEPLAN, 2010, p. 7). Tal diversidade étnica da região também se associa com alunos/as indígenas residentes de comunidades nos municípios de Cantá, Pacaraima, Normandia e Uiramutã, e de Santa Helena de Uairén (município venezuelano fronteiriço).

Há em Amajari 7 escolas municipais de ensino fundamental I e 24 escolas estaduais de ensino fundamental II e médio, tendo apenas uma não indígena, localizada na Vila Brasil (MATOS, 2013, p. 134) e ainda uma federal, que vem a ser o IFRR Câmpus Amajari, também não indígena. Este oferece ensino técnico profissionalizante integrado e concomitante em Agropecuária e Aquicultura. Também ministra ensino a distância em Cooperativismo, Informática e técnico subsequente em Agropecuária, com polos em várias comunidades indígenas do estado, além do ensino superior em Aquicultura.

Procurei, por questões de logística, manter contato com estudantes que vivem em áreas de Amajari com maior presença no câmpus: Três Corações, Guariba (TI Araçá) e TI Aningal. Também dialoguei com estudantes macuxi de Surumu, Contão e Uiramutã, que estão na TI Raposa Serra do Sol.

Perez (2010) faz uma descrição da organização da comunidade Araçá, situada na TI de mesmo nome, que envolve também as comunidades Três Corações, Guariba, Mangueira e 
Mutamba. De certo modo, a organização espacial descrita se repete na maioria das comunidades visitadas.

Os funcionários públicos moram na parte central da comunidade, onde as casas têm água encanada do poço artesiano da Funasa e energia elétrica da Companhia Energética de Roraima (gerador a diesel) e onde está localizado o telefone público, duas escolas (uma pré escolar e outra com ensino fundamental e médio), o posto de saúde da comunidade e pequenos comércios. Os demais moradores habitam o centro ou áreas mais afastadas. O vaqueiro mora no local de criação de gado bovino, conhecido como retiro. (PEREZ, 2010, p. 54)

Serão descritas nas seções seguintes as comunidades Três Corações, Guariba e Aningal (situadas em Amajari) e do Barro, no Surumu e Contão, na TI Raposa Serra do Sol, com a maioria das alunas/os que participaram da pesquisa.

\subsection{Comunidade Três Corações}

A comunidade Três Corações fica no entroncamento de duas rodovias importantes na região: a BR-174, que liga Manaus à Venezuela, cruzando o estado de Roraima, e a RR-203, que conecta a sede do município de Amajari, Vila Brasil (além de outras localidades, como a serra do Tepequém e diversas terras indígenas), ao acesso a Boa Vista. Ainda que ambas as rodovias estejam asfaltadas, a RR-203 está repleta de buracos e, por atravessar áreas de fazendas e de circulação de animais silvestres, requer muito cuidado dos motoristas.

A comunidade, também conhecida como Kilômetro 100, é muito afetada por essa situação. Acabou se tornando um local de descanso para quem se move em direção a Pacaraima e à Vila Brasil, sendo local de parada de ônibus, táxis e lotações intermunicipais. Há diversos estabelecimentos de comércio, principalmente de alimentação, sendo também um conhecido ponto de venda de gasolina trazida da Venezuela. Segundo Neto e Senhoras,

\footnotetext{
Esta expansão socioespacial do KM 100 não acontece por uma espontaneidade aleatória, mas antes, obedece a forças estruturais de longa duração, relacionadas às antigas rotas de fluxos indígenas e pecuários aonde se estrutura da BR 174 e da RR 203, bem como as forças conjunturais de dinamização do comércio formiga de produtos oriundos da Venezuela desde o período da redemocratização e o crescente aumento das porosidades fronteiriças. (2015, p. 37-38)
}

Assim sendo, é uma região com forte presença não indígena e uma comunidade marcada pela convivência e por casamentos entre os Macuxi e os Wapichana. Conversei com a pessoa que ocupa o posto de tuxaua da comunidade há anos. Ele é um macuxi de 54 anos e tem 12 filhos, dois deles estudantes do IFRR. Apenas um permaneceu na instituição.

O tuxaua também foi líder da comunidade Leão de Ouro por dez anos. Muito simpático, recebeu-me em sua casa em fevereiro de 2018. A comunidade Três Corações é uma das maiores 
da região. Segundo o tuxaua, são 3 mil moradores com uma diversidade cultural grande, pois há tanto indígenas de etnias diferentes quanto muitos não indígenas residentes.

Quando voltava da região do Surumu, na TI Raposa Serra do Sol, vi pelo menos três locais vendendo peixe, algo que não havia visto em minhas passagens em anos anteriores pela comunidade. Ele explicou que existiam seis poços artesianos e oito açudes, que já criavam peixes havia quatro anos aproximadamente. A relação, então, com o curso de Aquicultura do campus foi inevitável. Meu entrevistado, durante conversa informal em sua varanda, afirmou que a criação de peixes tem sido muito importante para os moradores, seja para o comércio seja para o consumo. No entanto, esses açudes não foram uma iniciativa do câmpus: decorreram de projetos do Ministério da Pesca.

Além do comércio, a renda também é potencializada por meio de programas sociais como Bolsa Família e Vale-Alimentação, bem como de atividades vinculadas ao serviço público estadual e municipal (BORTOLON, 2014, p. 82). Aquelas voltadas à agricultura se relacionam com o plantio de mandioca, limão, melancia e banana. Há, por fim, a criação de gado de forma extensiva para consumo externo e interno (p. 82-83).

As atividades tradicionais de caça e de pesca têm sido reduzidas em razão do desmatamento e da diminuição das terras disponíveis. Bortolon também faz referência à caça, que envolve comércio a preços altos na comunidade, e conclui:

\footnotetext{
o caçar e pescar faz parte da cultura indígena Macuxi, mas transformar essa cultura em um ato de exploração econômica de seu meio natural vem das formas de contato com a cultura do não indígena. A pesca serve como um importante suplemento de proteínas, mas a escassez obriga os indígenas a dependerem fundamentalmente dos alimentos industrializados, que são comprados no comércio regional. (p. 84)
}

Ainda assim, a presença de práticas culturais tradicionais vai se mantendo com outras definições. Apesar da existência de templos católicos e protestantes e, de certa forma, suas lideranças religiosas serem identificadas como o pastor ou o padre em detrimento dos pajés, benzedores/as ou o chamado "batedor de folhas" do passado não desapareceram e fazem remédios caseiros com plantas encontradas na mata. De acordo com as pessoas que ali vivem, o curandeiro/benzedor atua "como se fosse o Pajé" (BORTOLON, 2014, p. 82).

Além das práticas religiosas, as festividades apresentam elementos da tradição na vida da comunidade Três Corações. Durante as assembleias locais, as comemorações do dia do índio e a festa da padroeira da comunidade, Santa Luzia, dançam parichara, tradição da cultura macuxi da qual outras etnias participam. Essa dança tinha, segundo relatos de Koch-Grünberg citados em Bortolon (2014, p. 82), “a função de atrair peixe e caça em abundância”. De acordo com essa 
autora (p. 84), "são servidas as comidas e bebidas típicas como a damorida ${ }^{20}$, acompanhado do caxiri $^{21}$, do pajuaru ${ }^{22}$ ". Na festa da padroeira, há atividades "como as corridas de cavalos, vaquejadas, motocross, futebol e o baile ao som do forró, que foram reatualizadas pelas tradições indígenas em decorrência do contato com os não indígenas".

Entretanto, tais relações interétnicas e cruzamentos de práticas indígenas tradicionais com as não indígenas não interferem na indigeneidade ${ }^{23}$ dessa comunidade, pois, segundo Barth (2000, p. 26), “a interação não descaracteriza esses grupos sociais, mas as diferenças culturais podem persistir apesar do contato interétnico e da interdependência entre as etnias".

Há em Três Corações uma escola com ensino médio diferenciado. Essa unidade tem aulas das línguas macuxi e wapichana e, segundo o diretor (não indígena recém-escolhido pela comunidade escolar), conta com projetos pedagógicos que tentam estimular atividades culturais relacionadas à realidade indígena e a questões ambientais. Contudo, o gestor relatou resistência dos pais em permitir que seus filhos participem dessas atividades, por não as considerarem importantes para as/os estudantes. Pode-se dizer que as disciplinas e a rotina são praticamente as mesmas de todas as demais escolas não indígenas pertencentes à rede pública do estado. A seguinte imagem exibe a entrada da escola.

20 Peixe cozido apimentado.

21 Bebida feita da mandioca fermentada, que apresenta algumas variações de preparo conforme a região.

22 Bebida feita com beiju de mandioca enrolado na folha da bananeira.

23 Segundo Mignolo (2019, p. 4), "Em termos puramente etimológicos, indigeneidade é derivado de indígena, e, em termos puramente semânticos, refere-se à identidade de povos indígenas". 
Figura 8 - Fachada da Escola Estadual Indígena Santa Luzia

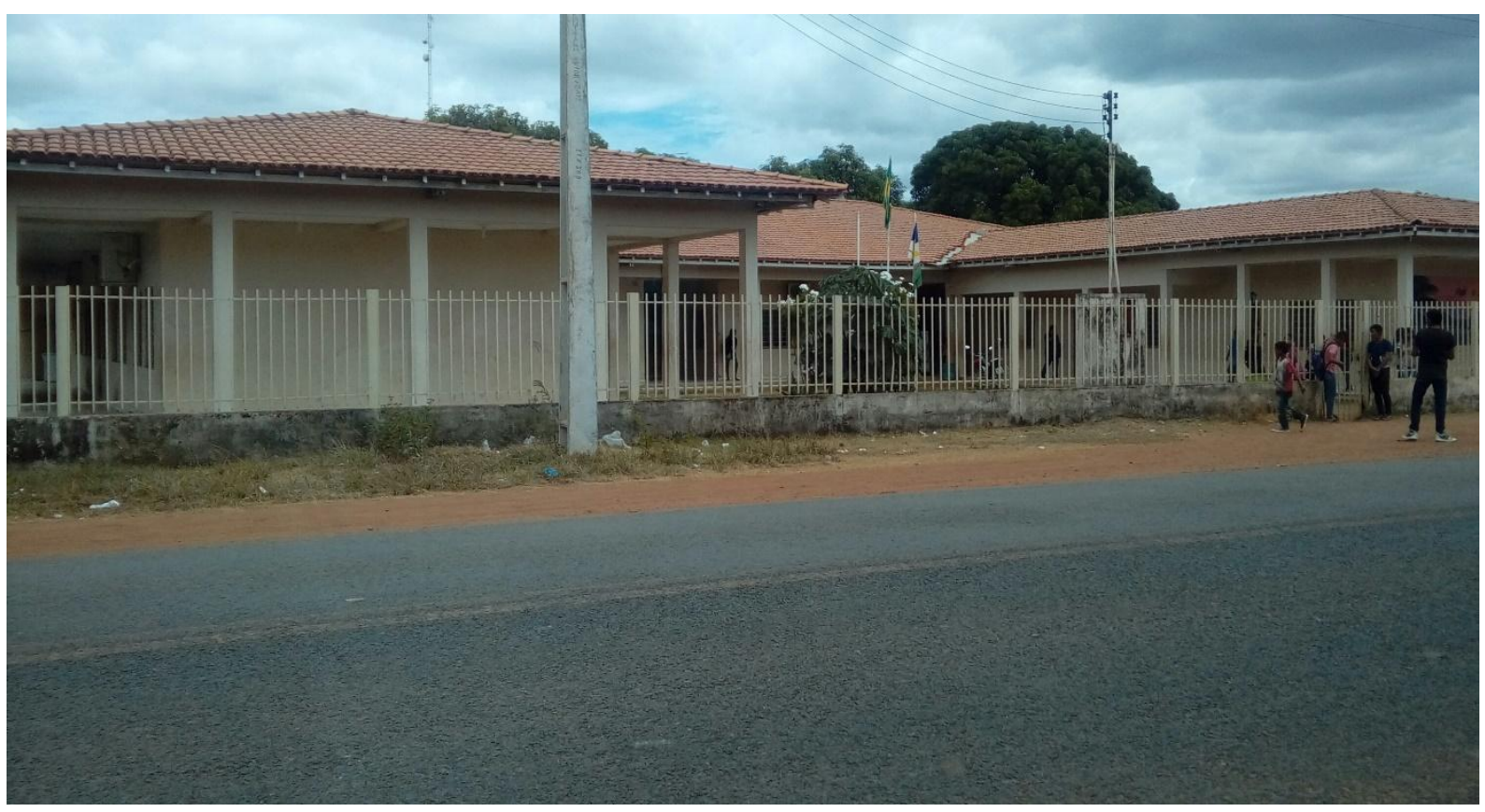

Fonte: Marcos Antônio de Oliveira. Mar. 2019.

O mesmo diretor apontou problemas relacionados com a estrutura do prédio. Estive ali em março de 2019 e as aulas não haviam se iniciado ainda. Ele relatou que, dos 20 professores, somente 11 eram efetivos, e que seria preciso um processo seletivo para contratação de substitutos. O auxílio-transporte não estava sendo suficiente e grande parte das/os alunas/os não estavam conseguindo chegar até a unidade escolar.

Havia também problemas na refrigeração das salas de aula, sem previsão de solução. Eram em torno de 50 estudantes no ensino médio e, segundo o diretor, muitos haviam optado pelo Câmpus Amajari por verem uma oportunidade de formação e qualificação mais adequada. Além disso, certamente não encontram no câmpus as dificuldades estruturais descritas pelo diretor da escola estadual. O IFRR fornece transporte para os alunos da comunidade todos os dias. Porém algumas alunas/os tiveram dificuldade de aprendizagem e retornaram para a escola da comunidade.

As/os alunas/os, segundo o gestor, demonstravam interesse em continuar seus estudos nas universidades da região. Em conversa com os e as estudantes, várias/os associaram o ensino "fraco" da sua escola à falta de qualificação dos professores, pois eles sabem que estes são em sua maioria "seletivados" (substitutos), muitas vezes não obtiveram diploma de curso superior ainda. No entanto, as/os jovens disseram gostar da escola e viam com ressalva a valorização cultural estimulada na comunidade. De modo geral, apresentaram pouco interesse em 
permanecer na comunidade e aspiravam a cursos superiores, com interesse em se instalar na capital.

Esses alunos/as enxergam o CAM como uma instituição com condições de fornecer uma boa educação com qualidade, mas não se sentem atraídos pelos cursos oferecidos nas áreas rurais. Pareceu-me que a descrição feita por Repetto (2012a) ainda se mantém entre as/os jovens de algumas comunidades:

\begin{abstract}
En medio de este panorama, lo cierto es que la escuela y su conjunto de conocimientos han manipulado conocimientos y valores. Esto se manifiesta en el desinterés de los jóvenes por dedicarse a la agricultura, con el argumento de que han estudiado para no tener que hacer trabajo físico en los campos. Así, se paraliza ideológicamente la fuerza de trabajo que tradicionalmente se desempeñaba en la tala de árboles para la actividad agrícola. Los alumnos están durante la mañana en la escuela, por la tarde en programas escolares que apenas los capacitan, al final del día juegan fútbol y en la noche ven televisión, quedando distantes de la socialización diaria y del trabajo. (p. 147)
\end{abstract}

\title{
1.5 Comunidade Guariba
}

Esta comunidade está a $42 \mathrm{~km}$ da Vila Brasil e o transporte oferecido pelo CAM leva e traz os estudantes. A tuxaua me recebeu em sua residência. Por sugestão dela, eu havia apresentado o projeto de minha pesquisa de doutorado em uma assembleia local. Nessa ocasião, visitei a Escola Estadual Indígena Tuxaua Manoel Horácio, que conta com ensino médio. Ali, conversei com as/os alunas/os e com a diretora.

A tuxaua, em 2018, era uma wapichana formada em Pedagogia, que já havia sido professora em escolas municipais da região. Nasceu lá e passou 16 anos em Boa Vista, casada com um herdeiro de uma fazenda desapropriada na região do Guariba. Mãe de três filhos, um dos quais foi vereador de Amajari. Os outros trabalhavam em Boa Vista. Havia se separado do marido. Acreditava ser a primeira mulher tuxaua na comunidade Guariba, que, segundo ela, tem predominância dos Wapichana. Segundo Bortolon (2014, p. 101), a população em 2012 era de 261 indígenas, sendo 37 macuxi e 224 wapichana.

Apesar da proximidade com a BR-174 e com a sede de Amajari, a comunidade Guariba me pareceu ter uma vida mais voltada à agricultura e à criação de gado, aves e peixes, porque é provida de oito açudes. Conforme relatado pela tuxaua, havia 87 famílias e 410 moradores. A área faz divisa com uma fazenda repleta de cabeças de gado. Cruzei com o rebanho, na volta de carro pela estrada vicinal que dá acesso à BR-203.

A comunidade tem uma escola de ensino médio diversificada e muito conhecida na região, que já foi tema tratado por Matos (2013). O estabelecimento conta com professores indígenas, ensino da língua macuxi e uma organização parecida com a da Escola Estadual Santa 
Luzia, na comunidade Três Corações. Há também horta e vários projetos para a comunidade. Em conversa com a diretora, em março de 2019, foi relatada dificuldade para compor o quadro de docentes, pois eram apenas dois efetivos. A própria diretora exercia a função desde 2017 , mas apenas em situação emergencial, pois havia sido escolhida pela comunidade e não existia outra pessoa em condições de assumir sua função. Ela estava cursando a Licenciatura Intercultural no Instituto Insikiran.

A tuxaua, na conversa que tivemos em 2018, valorizou as atividades de piscicultura e cultivo de pimenta, do Projeto Mulheres $\mathrm{Mil}^{24}$, do Câmpus Amajari. Também mencionou um projeto inicial de criação de aves, que estimulou o coordenador de extensão do CAM a auxiliar na construção do galpão e desenvolver projetos na comunidade.

O que parecia estar lhe causando preocupação era o projeto de criação de gado. Esse projeto, patrocinado pela Fundação Nacional do Índio (Funai), forneceria 50 cabeças de gado por um período de cinco anos e a comunidade ficaria com os bezerros criados durante esse período. Porém, para isso seriam necessários locais adequados para o manejo dos animais. Novamente, o coordenador de extensão ofereceu fornecer assessoria para construir o galpão dos animais e para envolver alunos em um projeto de extensão do IFRR. No entanto, em 2019, quando retornei, as promessas de ajuda técnica à comunidade Guariba não se realizaram, segundo o coordenador de extensão, por falta de verbas e interesse dos/das docentes.

A tuxaua também apresentou como fator de ida dos alunos ao Instituto a presença dos cursos técnicos. Alguns egressos trabalham nos projetos de piscicultura e criação de gado. Conversei com dois deles: uma jovem e um recém-formado do Instituto. A jovem macuxi iniciou um curso de agronomia, mas não conseguiu conclui-lo. O estudante estava sem emprego na comunidade e em dependência, ou seja, cursando disciplinas que não conseguiu concluir no período normal do curso de agropecuária. A organização econômica da comunidade repete a anterior e, por estar em uma área mais afastada e próxima a ilhas de mata ${ }^{25}$, possibilita um

24 “O Programa Nacional Mulheres Mil foi instituído nacionalmente em 2011 e é fruto dos resultados positivos gerados por uma iniciativa piloto de mesmo nome, criada em 2007 pela Secretaria de Educação Profissional e Tecnológica do Ministério da Educação (Setec/MEC). O objetivo do programa é promover a formação profissional e tecnológica articulada com aumento de escolaridade de mulheres em situação de vulnerabilidade social, especialmente das regiões Norte e Nordeste do país. Para isso, atua no sentido de garantir o acesso à educação a essa parcela da população de acordo com as necessidades educacionais de cada comunidade e a vocação econômica das regiões.” Disponível em: http://portal.mec.gov.br/programa-mulheres-mil. Acesso em: 23 mar. 2019.

25 A região é identificada como savana, ou lavrado, como é popularmente conhecida no estado de Roraima. É uma paisagem marcada por uma vegetação rasteira e durante os meses de novembro a março sofre com a estiagem. Entretanto, em locais próximos a igarapés e outras regiões determinadas, existem áreas com mata em abundância, que fornece alimentação para animais silvestres, tem árvores frutíferas e é propícia ao desenvolvimento da agricultura. Essas "áreas com vegetação mais densa (floresta estacional semidecidual e floresta ombrófila densa) 
desenvolvimento agrícola familiar maior e as atividades de caça ainda se mantêm. Há, por essa razão, produção de mandioca e criação de gado coletiva e familiar, além de criação de galinhas, porcos e patos para auxiliar na alimentação (BORTOLON, 2014, p. 105-106).

No Guariba predominava a religião evangélica, com a Igreja Assembleia de Deus. Não havia templo católico, mas vários indígenas se identificaram como católicos. Bortolon relata que, quando fez sua pesquisa de campo em 2013, havia somente um pajé na TI Araçá (BORTOLON, 2014, p. 104). A língua era o português, mas, apesar de a comunidade ter predominância de Wapichana, a língua ensinada na unidade escolar era o macuxi, em virtude da dificuldade de encontrar professores falantes de wapichana (p. 104). Assim, as relações interétnicas se repetiam ali, sem interferir na indigeneidade dos moradores.

Matos (2013) também estudou as escolas municipais e estaduais da comunidade Guariba e apontou algumas visões dos membros da comunidade e das/os alunas/os sobre a função da escola:

Houve diferentes opiniões quanto ao significado da escola para cada um e para a comunidade, variando de acordo com a representação social de cada um sobre essa instituição. Mesmo com diferentes justificativas, todos concordam sobre a importância das escolas para as pessoas e para a comunidade, por diversos motivos: i) porque com educação haverá desenvolvimento e melhor futuro tanto para as pessoas como para a comunidade; ii) a experiência de aprender coletivamente na escola fortalece a cultura coletiva local; iii) as escolas são importantes identidades institucionais da comunidade; iv) é significativo fortalecimento para o ensino da língua materna. (p. 188)

Esse fortalecimento é provável porque, sem o ensino das línguas nas escolas da região, dificilmente a geração atual teria contato com esse importante traço da cultura macuxi.

Em sua conclusão, Matos apontou questões referentes à escola que encontrou na comunidade Guariba. Entre estas, interessou-me uma situação que parece comum à tentativa de educação escolar indígena: a dificuldade de conciliar o tempo da burocracia dos órgãos oficiais (municipais, estaduais ou federais) e o tempo da comunidade. Como tudo é resolvido em assembleias e com a participação de todos os membros, o processo é mais lento e mais reflexivo e o não entendimento dessas diferenças gera conflitos (p. 230). Outra característica que parece ocorrer na organização das escolas é a influência do/a tuxaua. A pesquisadora observou que a comunidade era comandada por um tuxaua muito presente nas decisões da escola, uma das funções do cargo que a comunidade havia lhe designado (p. 232). Além dessa presença, constatei que a tuxaua do Guariba era gestora da escola de ensino fundamental I. Assim, sua influência era muito grande nos rumos da organização da educação escolar.

estão relacionadas às maiores elevações da paisagem e com solo diferente do encontrado nas áreas abertas. Essas áreas são chamadas de 'ilhas de mata'” (PEREZ, 2010, p. 7). 


\subsection{Comunidade Aningal}

A TI Aningal fica a $25 \mathrm{~km}$ do Instituto Federal Câmpus Amajari. Sua área é de 8 mil hectares e a população, segundo dados do CIR de 2015, chega a 245 habitantes, com um total de 38 famílias. Cinco alunos do Câmpus Amajari são oriundos dessa terra indígena. Para chegar à comunidade, a estrada é de terra e de difícil acesso, cercada por diversas fazendas. O CAM não oferece transporte e os alunos se valem de carona dos ônibus escolares municipais e estaduais ou da ajuda dos familiares. O tuxaua, católico, da etnia sapará, foi aluno do câmpus no curso de Agricultura, casou-se com uma wapichana e tinha cinco filhos/as, dois deles estudantes do IFRR de Amajari no curso técnico integrado em Aquicultura.

Tuxaua da comunidade desde dezembro de 2008, fez notar a importância da agricultura familiar, nos plantios de mandioca, milho, banana e cana-de-açúcar e na criação de gado em pequena escala. A maioria da produção é usada para consumo próprio e pouca coisa é vendida fora. Apesar do site do CIR identificar a comunidade como macuxi, na comunidade também estão presentes as etnias sapará e wapichana, sendo os Sapará predominantes. O tuxaua nasceu ali e disse que somente o avô falava a língua materna. Lamentou o fato de poucos ainda falarem a língua originária. Ele valorizou a possibilidade de contato intercultural entre os indígenas e não indígenas.

Concluiu o curso primário na comunidade, na Escola Estadual 31 de Março, posteriormente denominada Escola Estadual Indígena Inácio Manoel, que oferece ensino fundamental regular e ensino médio na modalidade EJA, com professores indígenas e ensino de língua originária. Quando estudava, ele tinha que se deslocar até a sede de Amajari, a Vila Brasil, para cursar o fundamental II e o ensino médio. Como a comunidade não contava com transporte, o traslado era feito de forma improvisada: carro próprio, carona, bicicleta e ônibus do Estado, quando disponível. Ele também disse que demorava 4 horas de bicicleta para chegar à Escola Estadual Ovídio Dias, na Vila Brasil, que foi a primeira sede do Câmpus Amajari.

Em 2009, o tuxaua iniciou o curso de técnico em Agricultura, o primeiro oferecido pelo Instituto. Em 2010, foi estudar no câmpus novo, onde completou o curso de Agropecuária. Exaluno e pai de aluno do câmpus, trouxe uma visão muito positiva do IFRR. Admirava a qualidade do ensino do Instituto e valorizou a estrutura física e os benefícios que o câmpus trazia. Quando foi feito o processo de discussão sobre o câmpus, ele participou como segundo tuxaua. Conforme ele declarou, o curso de Agropecuária foi sugerido pelas comunidades nas regiões nas quais houve a consulta pública. Dando como exemplo a própria comunidade, 
afirmou que à época temia que não fosse possível manter a produção sem uma formação adequada, pois o desmatamento vinha destruindo as ilhas de mata, inviabilizando os projetos e o desenvolvimento agrícola. Assim, acreditava que os conhecimentos do curso de Agropecuária os ajudariam a melhorar a produção.

Apesar de valorizar os conhecimentos do curso e entender ter sido uma demanda da comunidade, reconheceu que não conseguia viabilizar a presença dos egressos dentro da comunidade. Com exceção desse tuxaua, nenhum outro formado ficou. Geralmente, eles declaravam não haver condições de se manterem e, consequentemente, iam trabalhar em outra atividade como, por exemplo, de professor. Ele foi convidado para trabalhar como professor e não aceitou. Mencionou também um colega de classe que lecionava em Uiramutã.

O dono de uma fazenda conhecida por desenvolver criação de peixes na região, segundo o tuxaua, propôs um projeto desse tipo, oferecendo a estrutura necessária e os alevinos. Em seguida, a criação seria feita em 5 hectares, com cinco lâminas de água. No final, $60 \%$ do lucro da venda do peixe ficariam com a comunidade e $40 \%$, com o fazendeiro. Contudo, ele não soube explicar o motivo de não ter sido realizado o projeto.

Tendo em vista a demanda por criação de peixes nas comunidades mencionadas, acredito que o Instituto poderia ser mais sensível a essas necessidades e manter parcerias para essas ações em piscicultura.

O tuxaua incentivou seus filhos a estudar no câmpus porque acreditava ser possível aumentar as chances de acesso à universidade ou a uma carreira profissional melhor. Os filhos/as ficavam alojados na instituição.

A comunidade tentava preservar algumas práticas culturais, como o parichara. A maioria era católica e, anteriormente, havia a Igreja Adventista, algo que havia proporcionado certa divisão. Com efeito, surgiu a comunidade Nova União, impulsionada pela presença dos adventistas. Passou a não haver proibição das práticas religiosas indígenas na Aningal, que contava também com rezadeiras. 
Figura 9 - Área central da comunidade Aningal

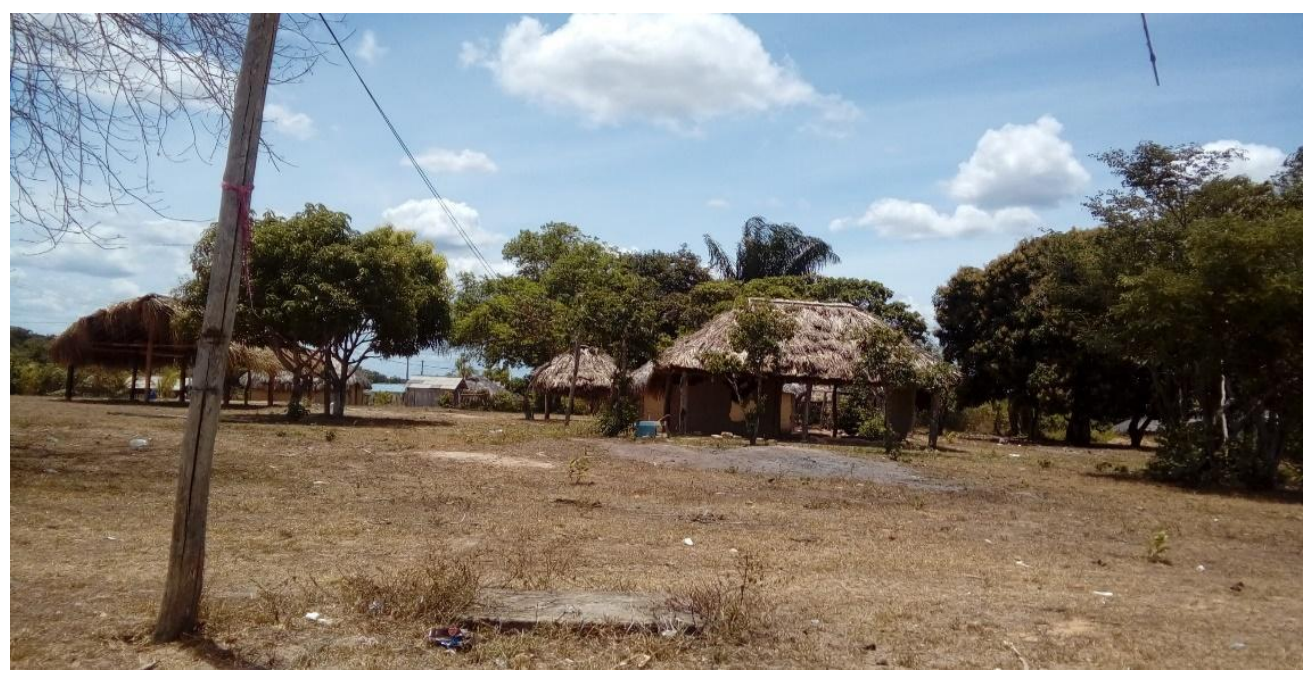

Fonte: Marcos Antônio de Oliveira. 2018.

Figura 10 - Malocão principal da comunidade Aningal

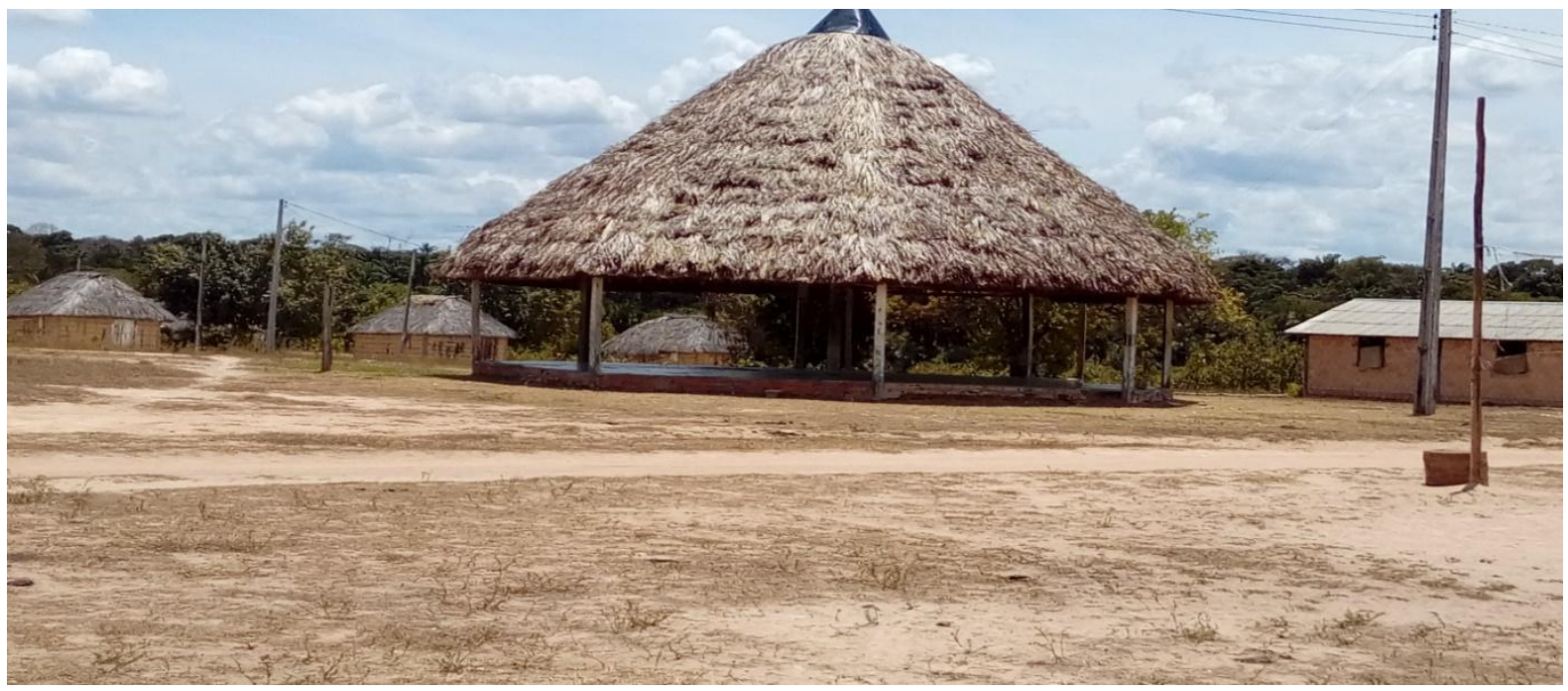

Fonte: Marcos Antônio de Oliveira. 2018.

\subsection{Comunidade Surumu}

A comunidade do Surumu pertence à TI Raposa Serra do Sol, fazendo parte das quatro etnorregiões ${ }^{26}$ que abrigam as etnias macuxi, taurepang, patamona, ingarikó e wapichana (SANTOS; GODOY, 2008, p. 5). A área da TI é de 1.747.464 ha, localizada no nordeste do estado, nos municípios de Pacaraima, Normandia e Uiramutã, entre os rios Tacutu, Maú,

26 Divisão político-administrativa utilizada pelos povos indígenas de Roraima, tendo como parâmetro a distribuição territorial e étnica no estado. 
Surumu e Miang. Há uma incidência montanhosa que culmina com o Monte Roraima na tríplice fronteira entre Brasil, Venezuela e Guiana. Segundo Santos (2016, p. 24), que utilizam dados de 2017 do Censo do Distrito Sanitário Especial Indígena (Dsei), habitavam na TI Raposa Serra do Sol 25.722 pessoas espalhadas em 210 comunidades. A comunidade Surumu tinha um total de 267 pessoas divididas em 69 famílias. A comunidade do Barro tinha 260 pessoas e 51 famílias, tendo predominância das etnias macuxi e taurepang.

Eu já havia visitado a comunidade do Surumu e do Barro na companhia de um professor do CAM durante as férias de janeiro de 2016, onde pude conhecer o Centro Indígena de Formação e Cultura Raposa Serra do Sol. Em fevereiro de 2018, o acesso à comunidade se deu com a ajuda de um senhor muito simpático que, em troca de uma carona, me apresentou o tuxaua da Comunidade do Barro e do Surumu. Aquele senhor era um macuxi, morador da comunidade Surumu, pai de oito homens e cinco mulheres, e que havia sido tuxaua da comunidade Mutum por nove anos. Ele estava levando um filho para participar da entrevista para comprovar sua origem indígena e também para entregar a documentação para a matrícula no $1^{\circ}$ ano do curso de Aquicultura.

O ex-tuxaua, muito perspicaz, percebeu a minha necessidade, ofereceu-se para me levar ao Surumu e me apresentar ao tuxaua Rodolfo Fernandes. Não pensei duas vezes e aceitei a oferta. Começamos uma viagem de 144 km pela BR-170 no sentido Pacaraima, e mais 29 km em estrada de terra batida. Fomos papeando durante o caminho todo.

Atendendo ao meu pedido, ele contou sua trajetória, desde o nascimento, em uma comunidade chamada Maturuca, até aquele momento, como morador da comunidade Barro na região do Surumu. Ele tinha muitas histórias cheias de peripécias e lutas para conseguir o direito garantido pela Constituição de acesso a suas terras originárias na região da TI Raposa Serra do Sol. Contou sobre a tentativa de o casarem aos 14 anos com uma indígena de 11, porque havia dançado com ela em uma festa da comunidade. Posteriormente, teve uma conversa com a noiva aconselhando-a a aguardar um período para conseguir alguns bens até que o casamento se realizasse. Conseguiu, assim, fugir da região e do matrimônio prematuro. Relatou que reencontrou a noiva abandonada 31 anos depois, sendo ela já avó.

Descreveu os conselhos do pai para que não se casasse com mulheres não índias. Elas o deixariam cedo ou tarde, por não ter suas demandas de consumo atendidas. O ex-tuxaua viveu em Boa Vista durante seis anos, onde conseguiu subempregos em supermercados e mecânicas, e trabalhos esporádicos de carregamento de mercadorias. Estudou até o antigo $4^{\circ}$ ano do primário em uma escola estadual com professores não indígenas e falava muito pouco a língua macuxi. Assumidamente católico, ele disse não ter tido muito acesso à religião originária. 
Seu pai faleceu, vítima de malária, e ele se casou com uma indígena, tendo que trabalhar três meses na comunidade da noiva para mostrar que conhecia agricultura e que não era preguiçoso. Em uma reunião com toda a família da noiva, foi aceito como esposo. Construiu, então, sua casa e levou suas 20 galinhas.

Em sua experiência como tuxaua por nove anos na comunidade Mutum, fez um teste bem-sucedido com piscicultura, muito útil para a comunidade, segundo disse. Saiu dali para acompanhar o filho, que queria estudar no Centro Indígena de Formação e Cultura Raposa Serra do Sol. Trata-se de um estabelecimento histórico porque é a primeira escola técnica e diferenciada da região. Foi concebida para servir aos interesses da colonização, sendo usada inicialmente como local de formação de indígenas em serviços manuais e paulatinamente foi sendo transformada e apropriada pelos indígenas. Essa instituição foi queimada em 2004 durante o processo de demarcação da TI Raposa Serra do Sol. Ali, o filho do ex-tuxaua fez o curso de Técnico em Agricultura. No entanto, ele lamentou que o adolescente não tenha obtido emprego na comunidade e muito menos utilizado seus conhecimentos na região, por falta de recursos e apoio.

Esse senhor macuxi fez um curso de preparo de couro a partir do qual confeccionava selas de montaria e outros tipos de artesanato: colares feitos de coco, de dente de boto e de porco do mato. Ele descobriu uma nascente onde pretendia fazer tanques para criação de peixes e assim repetir o sucesso na comunidade anterior. Penso que essas eram possíveis razões para o interesse do filho em ficar alojado longe da comunidade, estudando Aquicultura no Instituto.

Perguntado sobre o porquê de desejar que seus filhos estudassem no Instituto e não na comunidade, alegou ter sido escolha do filho. Este, que se manteve calado durante toda a viagem, com um fone em um dos ouvidos, respondeu que, na comunidade, ocorre muita falta de professores, e o Instituto, na visão dele, permitiria uma boa oportunidade de emprego.

Seu pai disse que os alunos não conseguiam se empregar localmente, mesmo com os cursos técnicos, devido a "problemas internos da comunidade", falta de recursos para realizar o que se aprende e desinteresse dos adolescentes em trabalhar nas comunidades.

Chegando no Surumu, não encontramos o tuxaua Rodolfo, que estava em Boa Vista. Mas encontramos o tuxaua da comunidade Barro, da região do Surumu. Essa região tem sua existência vinculada à evolução da luta pela autonomia dos seus povos indígenas nas relações com não indígenas, que culminou na demarcação da TI e na criação de um símbolo dessa luta, o Centro Indígena de Formação e Cultura.

As tensões que envolveram esse processo fizeram com que a comunidade se dividisse em duas partes: a comunidade do Barro, relacionada com o Conselho Indígena de Roraima 
(CIR), que sempre apoiou a demarcação em forma contínua, e a Surumu, que apoiava a permanência de não índios na TI, como alternativa para manter empregos nas fazendas de rizicultura e pecuária assim como na exploração do garimpo. Na região, destaca-se a escola indígena particular diferenciada de ensino técnico profissionalizante, que é gerida pelo CIR.

Figura 11 - Centro Indígena de Formação e Cultura Raposa Serra do Sol

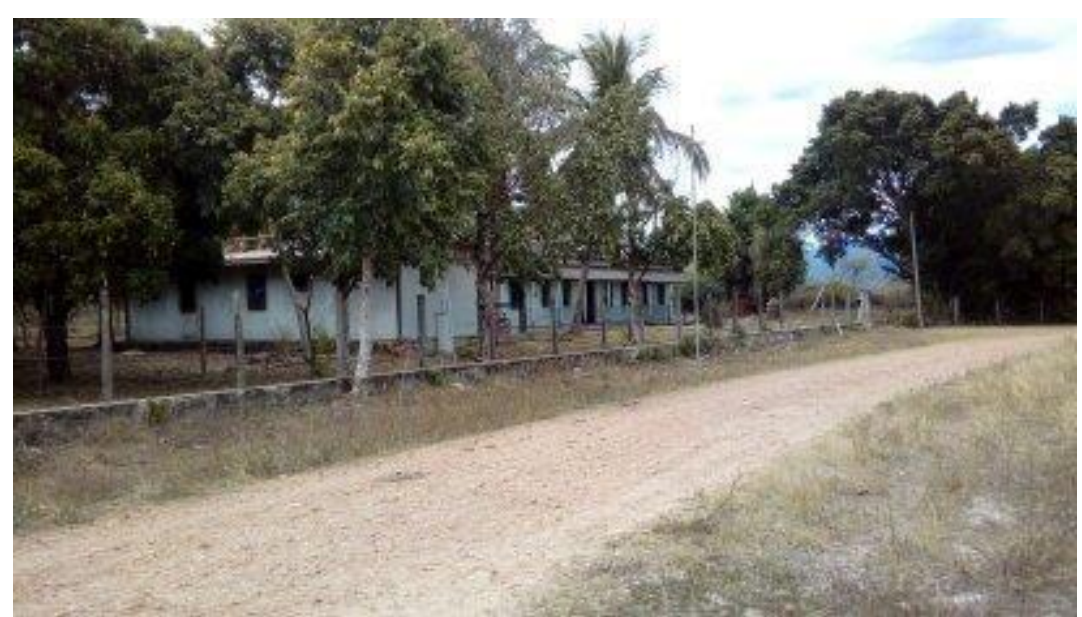

Fonte: Marcos Antônio de Oliveira. 2018.

Figura 12 - Vista da antiga igreja do CIFCRSS

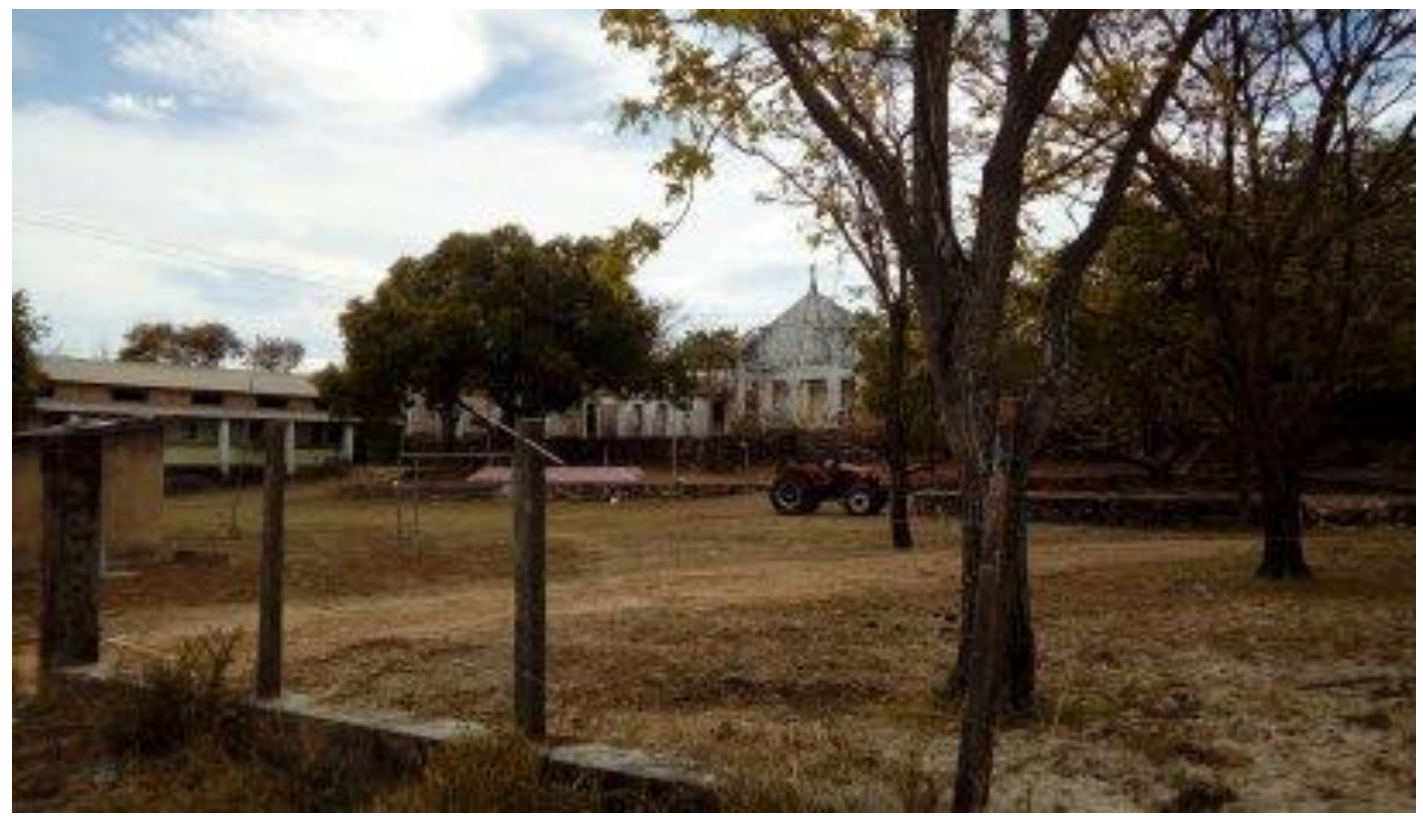

Fonte: Marcos Antônio de Oliveira. 2018. 
Figura 13 - Placa de identificação do CIFCRSS

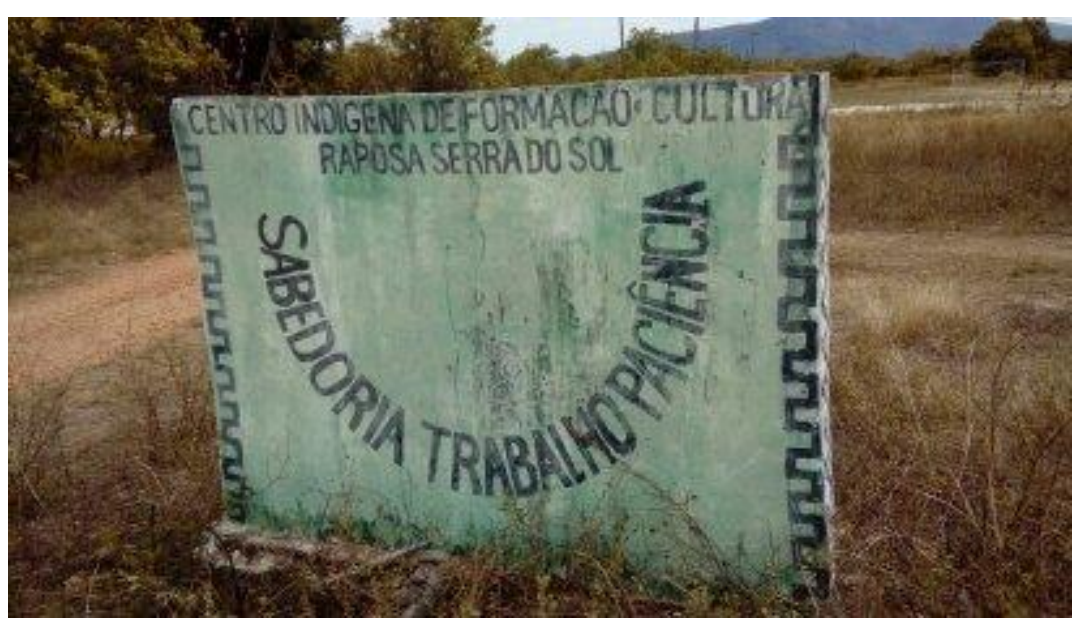

Fonte: Marcos Antônio de Oliveira. 2018.

$\mathrm{Na}$ antiga Missão do Surumu, fundada pelos beneditinos, foi realizada a ${ }^{\text {a }}$ Assembleia dos Tuxauas dos povos que lutavam pela autodeterminação na região, em 1977 (PERES, 2013, p. 25). O encontro foi organizado pelos padres da Ordem da Consolata, auxiliados pelo Cimi (Conselho Indigenista Missionário). A ordem religiosa manteve até 2008 um hospital e uma escola em sistema de internato no Surumu.

Nessa Assembleia de 1977 estiveram 140 pessoas das etnias macuxi, wapichana e taurepang, 50 das quais eram das comunidades locais (VIEIRA; SILVA, 2016, p. 329). O encontro foi marcado pelos conflitos envolvendo o presidente do Cimi, Dom Tomás Balduíno, crítico da Funai, e Dom Aldo Mogiano, o bispo de Roraima. Após dois dias de reuniões, a Assembleia foi dissolvida pela Polícia Federal e pela Funai, que não concordavam com a presença do presidente do Cimi. Em 1978, as lideranças indígenas organizaram encontros regionais de forma autônoma na Raposa Serra do Sol, Surumu, Taiano e Serra da Lua, seguidos do grande encontro de 1979, chamado de $2^{\text {a }}$ Assembleia dos Povos Indígenas de Roraima, novamente acontecendo na antiga Missão do Surumu (COSTA FILHO; SANTOS, 2016, p. 212). Em 1983, com a presença de 250 indígenas, sendo 72 lideranças, foi criado o Conselho das Comunidades. Estas eram, segundo Santilli (2001, p. 43), “instâncias supra-aldeãs, descoladas das comunidades locais, compostas por representantes de áreas geográficas, delimitadas pela concentração de aldeias e sobretudo pela influência dos missionários, articulados às lideranças indígenas". $\mathrm{Na}$ Assembleia de 1984, foram criados os conselhos regionais nas seguintes áreas: Serras, Surumu, Amajari, Serra da Lua, Raposa, Taiano e Catrimani, incumbidas, segundo Santilli, de "gerir as relações externas de comunidades indígenas, tanto no plano das relações com a sociedade regional como na formulação e 
direcionamento dos projetos indigenistas, patrocinados por diferentes agências" (SANTILLI, 2001, p. 43).

Os conselhos regionais formaram uma coordenação geral, sediada em Boa Vista, para poderem atuar mais intensamente com os poderes públicos. A coordenação deu origem ao Conselho Indígena de Roraima. Os membros do Conselho seriam, ainda segundo Santilli (2001, p. 44) "eleitos pelo voto aberto dos conselheiros regionais, respeitando-se um esquema de rodízio de lideranças (...) o Conselho foi registrado como sociedade civil”".

O CIR se tornou a principal organização indígena de Roraima. A partir do Surumu, foram se fortalecendo as organizações indígenas que depois seriam protagonistas no enfrentamento das questões de interesse dos povos da região:

Desde dicho Centro surgieron debates que posteriormente se han multiplicado en las
comunidades indígenas, como son el de proyectos sociales y de "autosustentabilidad",
la necesidad de tener garantía con respecto a la posesión de la tierra y acerca del derecho
a la identidad, así como sobre la participación en las nuevas directrices económicas del
país y del mundo. (REPETTO, 2012a, p. 134)

Da comunidade do Barro, situada no Surumu, vieram vários/as alunos/as de técnico em Agropecuária, no regime de alternância e no ensino médio integrado. Esses/as alunos/as passavam 15 dias na instituição estudando a parte teórica (tempo-escola) e, depois, o mesmo período na comunidade (tempo-comunidade), desenvolvendo projetos orientados pelos/as professores/as.

O tuxaua me recebeu em sua casa e, debaixo de uma mangueira, quis ouvir o que eu desejava. Expliquei-lhe minha pesquisa e o interesse em compreender os motivos que levavam adolescentes indígenas a viajarem $144 \mathrm{~km}$ até o Instituto para estudarem em um curso também oferecido no Centro Indígena de Formação e Cultura Raposa Serra do Sol. O tuxaua havia sido coordenador desse Centro por dez anos, período em que houve um incêndio, no auge das disputas pela TI. Ele disse que as decisões dos pais eram respeitadas pela comunidade. Também se mostrou feliz em saber que pessoas vinculadas ao Instituto estavam querendo ouvi-los, acreditando que isso ajudaria a dar condições para os jovens terem uma estadia mais tranquila no câmpus. Mas ele se queixou por saber pouco sobre a vida escolar desses alunos e por não observar projetos desenvolvidos na comunidade do Barro. Para o tuxaua, a escola seria muito importante para formar lideranças e professores. Lamentou, porém, a ausência dos jovens nas comunidades: muitos continuavam seus estudos em universidades e não retornavam.

Estudantes que entrevistei disseram ter estudado no Centro Indígena de Formação e Cultura. Dois deles tinham feito até o $2^{\circ}$ ano do curso, que também era em regime de alternância, quando abandonaram para reiniciar no curso de Agropecuária do CAM. Apontaram 
dificuldades de estrutura, falta de professores e incompreensão da proposta pedagógica do Centro ${ }^{27}$. Alegaram buscar uma instituição que fornecesse um "ensino forte", o que seria o caso do Instituto.

Figura 14 - Mapa das comunidades na TI Raposa Serra do Sol

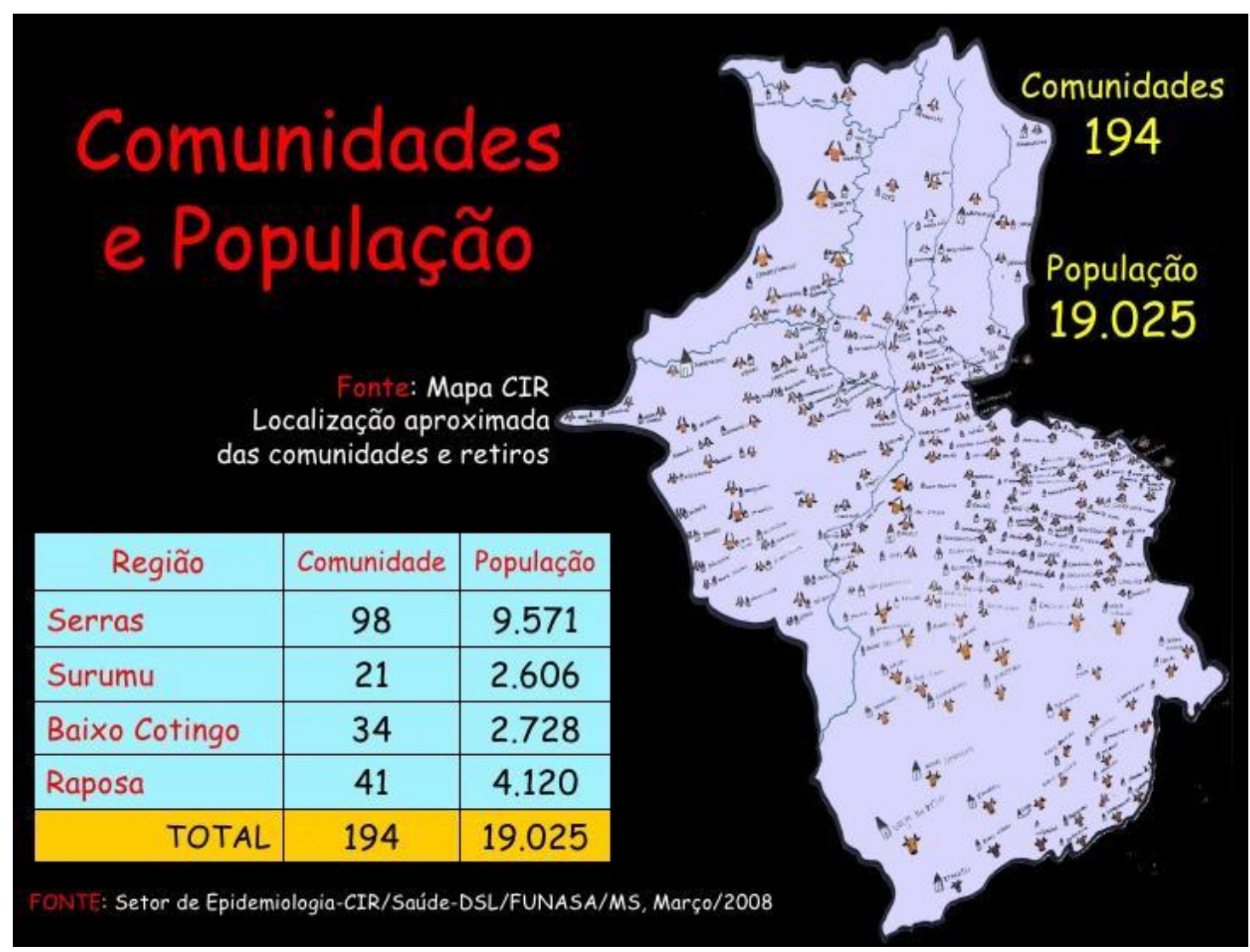

Fonte: Setor de Epidemiologia CIR/Saúde-DSL/Funasa/MS. Mar. 2008.

\subsection{Comunidade do Contão}

No Contão ocorriam as atividades dos/as alunos/as da alternância, e muitos/as da comunidade estudavam no Instituto. O segundo tuxaua, um macuxi, ocupava o cargo desde 1988. Era casado havia 17 anos com uma macuxi oriunda da comunidade Cantagalo. Seus três filhos são adultos, casados, e moravam no Contão. Ele estudou apenas até o fundamental I. Falava a língua macuxi apenas com os mais velhos. Em seu núcleo familiar, ninguém falava essa língua.

27 Para entendimento da proposta pedagógica do Centro Indígena de Formação e Cultura Raposa Serra do Sol, ver Santos e Godoy (2011). 
Sendo evangélico, da Igreja Batista, disse não praticar a religião indígena porque o pastor Paulino Raposo, também macuxi, proibiu. Em sua comunidade havia criação de gado e ele tinha 60 cabeças, tendo começado com apenas 5. Utilizava a carne e o couro para consumo próprio e para venda dentro da comunidade.

O antropólogo Lisboa (2017a) tratou da presença de indígenas na Universidade Federal de Roraima e relatou suas experiências durante trabalho de campo que acompanhou os acadêmicos e suas participações em eventos no Câmpus Paricarana e outros locais públicos de Boa Vista. Em um desses eventos, um seminário sobre os povos indígenas, mencionou o professor Alvino Andrade ${ }^{28}$, macuxi formado em Ciências Sociais, que "fez uma análise contundente dos efeitos da noção de etnodesenvolvimento e a experiência dos Macuxi nas terras indígenas do estado" (p. 122). Nessa palestra, Andrade descreveu o Contão como a comunidade com o maior número de indígenas macuxi (1.200 indivíduos) e onde, no entanto, apenas 25 pessoas falavam a língua e somente 100 a compreendiam. Ele também lamentou a diminuição do uso da "roça tradicional" e disse que apenas 50 famílias ainda a mantinham.

Na comunidade, de acordo com o segundo tuxaua, cultivava-se também milho, arroz, feijão, mandioca e melancia. Esses cultivos eram comercializados e consumidos pelas famílias. O Contão fica a quase $200 \mathrm{~km}$ do Câmpus Amajari e muito próximo da comunidade Surumu, onde funciona o Centro Indígena de Formação e Cultura Raposa Serra do Sol, que oferece curso de Agropecuária assim como o IFRR. De acordo com o entrevistado, a comunidade e as lideranças locais não estimulavam os estudantes a frequentarem o Centro Indígena de Formação, pois havia divergências políticas com o CIR, que o administrava. A comunidade estava vinculada a outra organização indígena, a Sociedade de Defesa dos Índios Unidos do Norte de Roraima para o Desenvolvimento (Sodiur).

Ele também contou que a comunidade precisava de estudantes com formação técnica para colaborar na melhoria da produção local. Apontou dificuldades para conduzir determinados

28 Infelizmente o professor Alvino Andrade da Silva foi vitimado pela Covid-19 em 20 de junho de 2020, com 59 anos de idade. Silva era da etnia macuxi e foi um dos responsáveis pela elaboração do Insikiran, instituto para formação de indígenas da Universidade Federal de Roraima (UFRR). Ele tinha formação em Sociologia e Filosofia. Também coordenou o projeto "E'ma Pia", que garante o ingresso de alunos indígenas nos cursos da UFRR através de um processo seletivo específico para índios. Disponivel em: https://g1.globo.com/rr/roraima/noticia/2020/06/21/militante-indigena-que-atuou-na-criacao-do-insikiran-edemarcacao-da-raposa-serra-do-sol-morre-de-covid-19-em-rr.ghtml. Acesso em: 30 nov. 2020. Sobre as consequências da pandemia nas comunidades indígenas de Roraima, ver GUIMARÃES, L. M. de A.; FERREIRA JÚNIOR, A. (2020). 
projetos por falta de conhecimento técnico. Com um açude de cinco tanques para a criação de peixes, não conseguiam realizar essa atividade por falta de técnicas adequadas.

Portanto, considerou a parceria com o IFRR muito importante e necessária. Apoiava os estudantes e esperava que permanecessem na comunidade. De acordo com o meu entrevistado, que foi escolhido como tuxaua em 2019, os alunos foram selecionados por livre vontade e incentivados a participar, sem pressão dos pais ou das lideranças. Constituíram a primeira turma de alternância totalmente indígena do CAM, toda da etnia macuxi. Eles/as relataram ter sido motivados/as a ir ao Instituto para ter acesso a uma boa formação e obter uma qualificação técnica, que poderia ajudar na comunidade.

A Escola Estadual Indígena José Marcolino é mencionada por Repetto (2006, p. 79-80) como uma unidade escolar que teve muitas dificuldades para entender a proposta pedagógica que tentava implantar o ensino médio diferenciado na região, sendo que "alunos e pais manifestaram um desejo forte de privilegiar mais os novos conhecimentos técnicos do que os culturais considerados tradicionais, apesar de reconhecerem que o horizonte cultural deve se fazer presente, com a língua e a cultura aparecendo e se manifestando” (p. 79).

Segundo Repetto (p. 82), “os estudantes foram abertamente contrários à implementação de uma 'educação diferenciada e específica' para os povos indígenas. Eles reivindicaram, em vez disso, uma educação de qualidade que para eles significava uma escola que trabalhe com os mesmos parâmetros das escolas da cidade". Portanto, é perfeitamente compreensível o interesse dessa região pela parceria com o CAM, cuja oferta de um curso técnico profissionalizante atenderia aos interesses de produção e "desenvolvimento" para a região. É necessário lembrar, as lideranças dessa região foram contrárias à demarcação da Terra Indígena Raposa Serra do Sol de forma contínua, pois viam na presença dos fazendeiros e rizicultores e na prática do garimpo possibilidade de trabalho e "desenvolvimento".

Entretanto, os defensores da demarcação de forma contínua viam no fortalecimento da valorização cultural um elemento muito importante nas propostas pedagógicas, sem descartar a formação profissional e propondo o desenvolvimento comercial interno das comunidades como objetivo final.

A seguinte imagem representa a Escola Estadual Indígena José Marcolino, chamada anteriormente de Fernão Dias, nome que ainda se mantinha na placa. A maioria dos/as alunos/as estudou nessa escola e desenvolvia atividades da alternância ali, tais como reunião de pais e encontros. 
Figura 15 - Escola Estadual José Marcolino (a placa traz o nome antigo). Comunidade do Contão

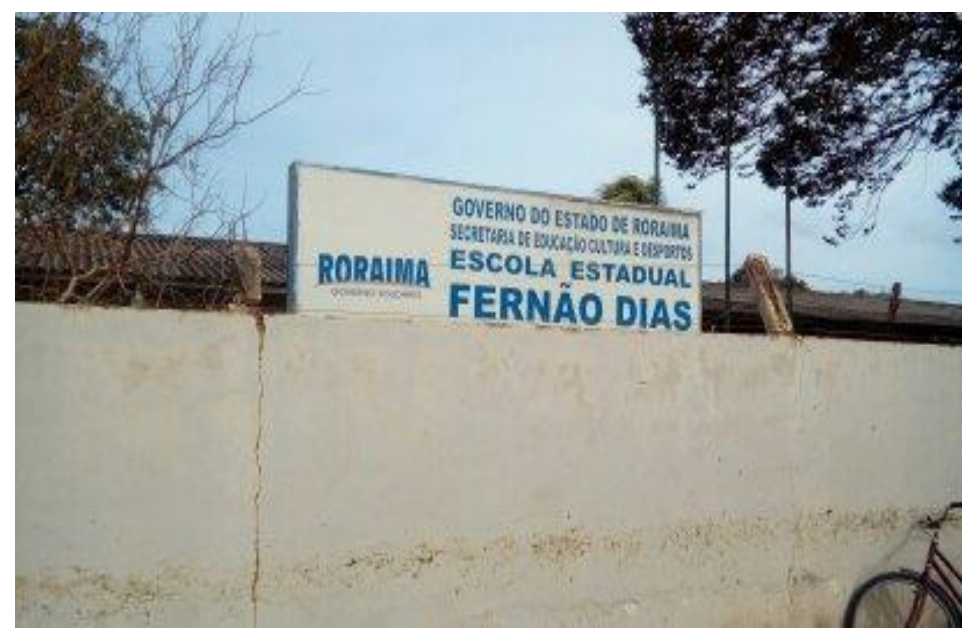

Fonte: Marcos Antônio de Oliveira. 2018.

Figura 16 - Áreas onde são realizados os projetos dos alunos de alternância no Contão

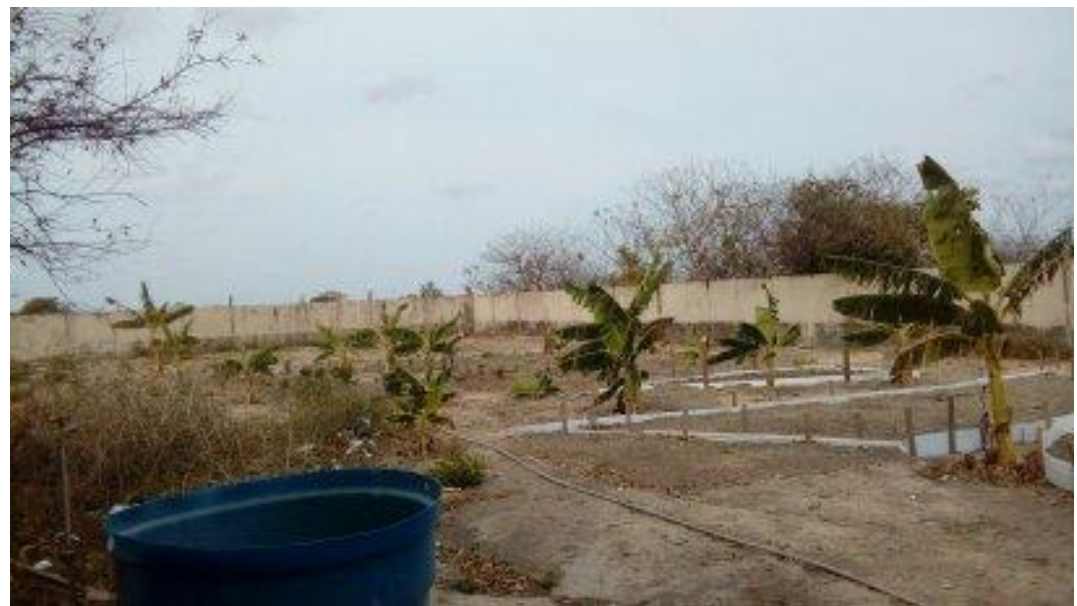

Fonte: Marcos Antônio de Oliveira. 2018.

$\mathrm{Na}$ escola indígena, conversei com um professor e uma professora (que exercia a função de orientadora pedagógica) com cargo efetivo. O primeiro dava aulas de matemática nas turmas de $8^{\circ}$ e $9^{\circ}$ anos do nível fundamental. Macuxi, que também não dominava a língua, ele era formado em Magistério e trabalhava ali desde 2013. Mencionou a conclusão do ensino médio por 60 alunos/as em 2018.

A orientadora educacional, também macuxi e efetiva no cargo, era formada em Pedagogia pela Universidade Estadual de Roraima, no sistema de ensino a distância. Preocupava-se com a pouca motivação das/os estudantes para concluir o ensino médio. Estes faltavam muito às aulas e, em visitas às residências deles para averiguar as razões do absenteísmo, encontrou "falta de interesse", além da ausência de transporte e de trabalho. 
Figura 17 - Área organizada em fomas geométricas para as aulas de matemática

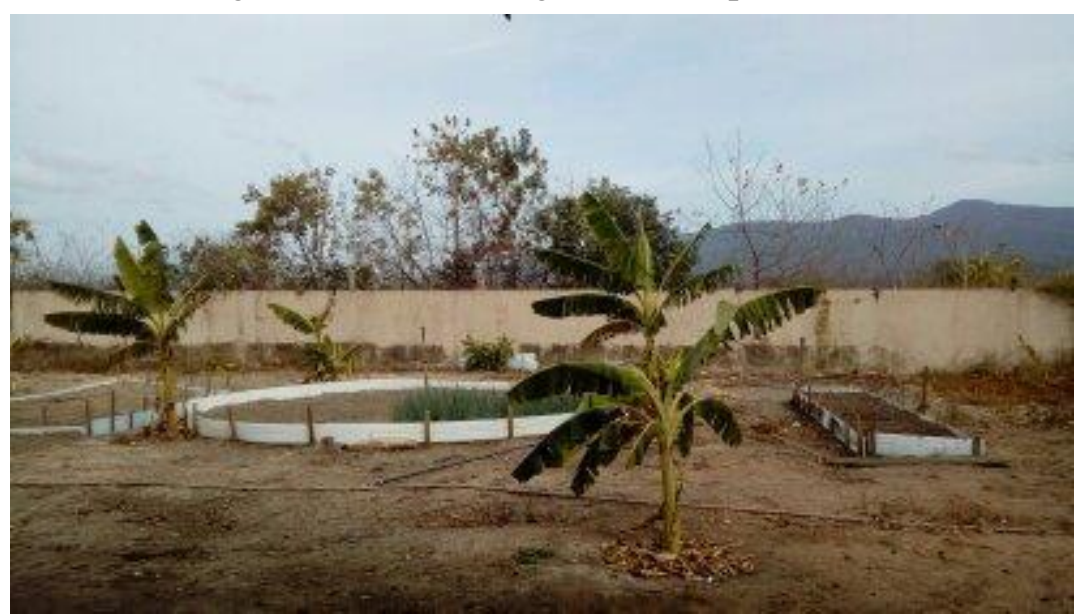

Fonte: Marcos Antônio de Oliveira. 2018.

A professora com quem falei tinha uma filha concluindo o ensino superior em Aquicultura do CAM e se disse satisfeita com a possibilidade de ela vir a ajudar na comunidade, pois, conforme assinalei, os tanques de piscicultura não estavam em funcionamento por falta de mão de obra qualificada. Tanto o professor quanto a professora da escola apontaram a dificuldade dos/as alunos/as em se empregar na comunidade. A alternativa universitária acabava sendo uma saída para a ociosidade dos jovens na região, ainda que nem todos conseguissem acesso à formação superior.

\subsection{Os Macuxi}

Os Macuxi ${ }^{29}$ vivem na área do Monte Roraima, entre a Gran Sabana, na Venezuela, os campos do rio Branco, no Brasil, e as savanas do alto vale do Rupununi, na Guiana Inglesa. Macuxi é uma designação para os grupos que habitam o sul da área conhecida como circumRoraima, as vertentes meridionais do Monte Roraima e os campos e savanas, que se estendem pelas cabeceiras dos rios Branco e Rupununi, entre a Guiana Inglesa e o Brasil (SANTILLI, 2001, p. 19). Esse povo se autodenomina Pemon, e sua língua está classificada no tronco linguístico Karib. Abaixo, a localização predominante dos povos Macuxi aparece destacada em amarelo no mapa do estado de Roraima. 
Figura 18 - Mapa das Terras Indígenas em Roraima

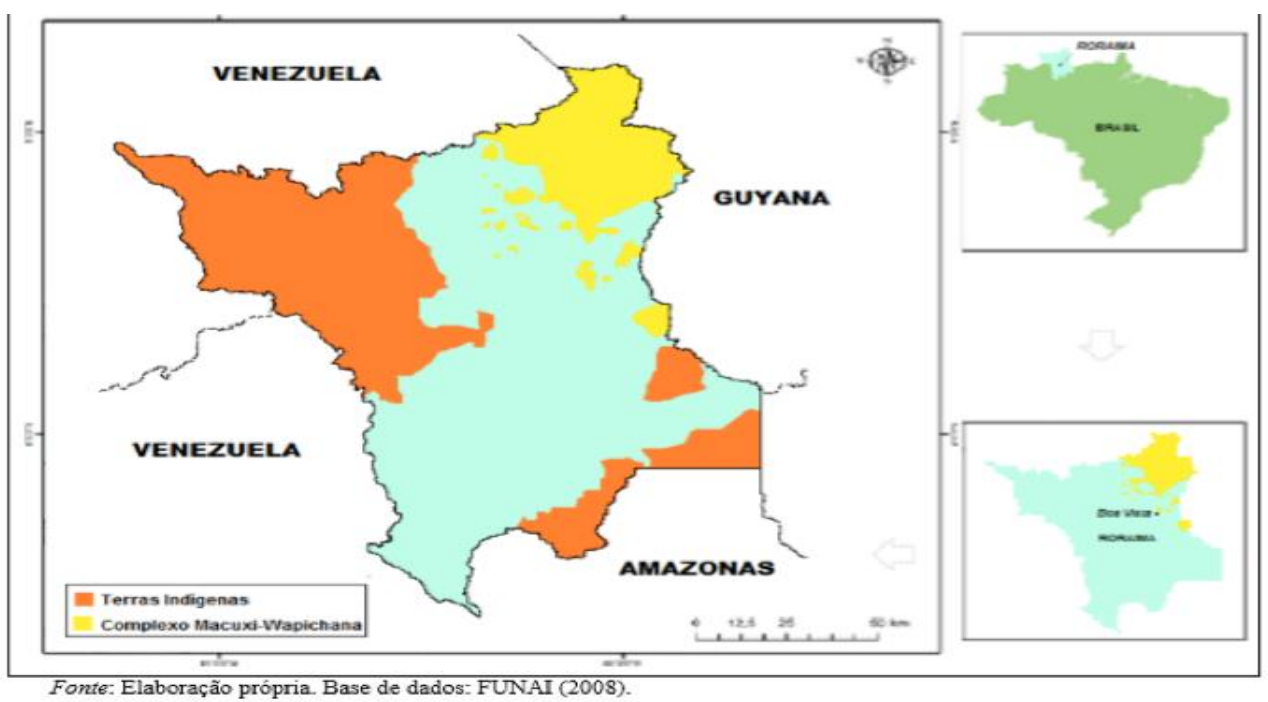

Fonte: SOUZA et al., 2017, p. 18.

Há, em Roraima, 32 terras indígenas, divididas entre terras contínuas (Yanomami, São Marcos e Raposa Serra do Sol) e terras em blocos ou ilhas (Ponta Serra, Araçá, Barata/Livramento e Mangueira), sendo 6 de predominância wapichana, 5 macuxi e outras 17 mistas entre macuxi, wapichana e taurepang. A maioria dos Macuxi se concentra nas reservas São Marcos e Raposa Serra do Sol (PERES, 2013, p. 17).

A economia dos Macuxi se concentra na pecuária e na agricultura: banana, abacaxi, melancia e mandioca para a produção da farinha e do beiju. De acordo com Peres (2013, p. 24), a agricultura tem perdido gradativamente espaço no cotidiano, pois "Muitos Macuxi têm deixado a comunidade para procurar trabalho como domésticas, vaqueiros, pedreiros, caseiros, braçais e outros. Alguns conseguem encontrar trabalho como servidores públicos do estado e dos municípios".

A presença macuxi em Boa Vista, capital do estado, é muito grande, e os dados são imprecisos. Os da prefeitura apontam, por exemplo, 31 mil indígenas aproximadamente, mas não especificam as etnias (PERES, 2013, p. 19).

No âmbito político, a direção da atividade macuxi se divide entre as/os tuxauas, líderes escolhidos pelas comunidades, e as 20 organizações indígenas, das quais se destacam as seguintes: Aliança de Integração e Desenvolvimento das Comunidades Indígenas de Roraima (Alidcir), Sociedade de Defesa dos Índios Unidos do Norte de Roraima para o Desenvolvimento (Sodiur), Conselho Indígena de Roraima (CIR), Sociedade para 
Desenvolvimento e Qualidade Ambiental (TWM), Associação dos Povos Indígenas de Roraima (Apirr), Organização das Mulheres Indígenas de Roraima (Omir), Organização dos Professores Indígenas de Roraima (Opirr). Essas representações auxiliam as comunidades nas assembleias para o tratamento de temas voltados para a educação indígena, saúde, território, projetos econômicos comunitários e governamentais (PERES, 2013, p. 20-21).

Durante o trabalho de campo, participei de duas assembleias envolvendo as lideranças da região de Amajari ligadas ao Conselho Indígena de Roraima (CIR), bem como de uma reunião da comunidade Guariba. Essas reuniões demonstraram como organizações não governamentais (ONGs) estrangeiras e nacionais têm ajudado esses povos a desenvolverem sua autodeterminação - e também como têm gerado conflitos internos por recursos e quanto a novas necessidades que foram surgindo pelos projetos de criação de gado e piscicultura, que essas organizações têm incentivado nas comunidades da região.

Isso também reforçou minha impressão de haver alto grau de organização de algumas comunidades para conseguir sobreviver nesta região do Norte brasileiro. Contudo, trata-se de uma organização concentrada nas lideranças, enquanto a maioria apenas recebe orientações e sugestões e tenta reproduzir o que lhe é proposto. A maior parte dos/as alunos/as macuxi que entrevistei considerou essas reuniões maçantes e muito cansativas. Elas chegam a durar dias, sem horário para terminar, dificultando a participação de todos os membros da comunidade. Mesmo assim, acontecem periodicamente e são oportunidades para as pessoas da comunidade se manifestarem.

Santilli (2001, p. 39-40) acredita que, historicamente, as aproximações com os não indígenas se deram desde o século XVI até meados do XX por meio de relações clientelistas com os povos indígenas da região, acarretando muitas vezes conflitos e violência. O Serviço de Proteção ao Índio (SPI), os missionários beneditinos, posteriormente substituídos pelos missionários da Consolata, e a Funai sucessivamente tentaram exercer algum tipo de influência sobre os povos indígenas de Roraima para "moldá-los à civilização cristã”.

Tal "padrão clientelista" foi buscado pelos Macuxi para terem acesso a bens manufaturados fornecidos pelas agências indigenistas, que supririam as necessidades das comunidades criadas pelo contato. O processo foi conduzido por lideranças regionais e culminou nas organizações indígenas, que foram surgindo como uma alternativa à relação exploradora pautada pelo Exército, fazendeiros, políticos, garimpeiros, mineradoras e madeireiras (SANTILLI, 2001, p. 41). 
A luta pela terra, educação e saúde movida pelos povos de Roraima se iniciou nos anos 1970 e se aprofundou nos anos 1980, após as mudanças constitucionais favoráveis aos povos indígenas. Posteriormente, ligou-se à luta pela educação diferenciada e bilíngue, que passou a mobilizar as associações indígenas locais. No capítulo seguinte, essa mobilização em torno da educação será visibilizada, com enfoque no ensino médio regional e indígena. 


\title{
CAPÍTULO 2. ESTUDANTES MACUXI NO ENSINO MÉDIO DE RORAIMA
}

O presente capítulo aborda a chamada educação escolar técnica profissionalizante desde o século passado, focalizando sua principal proposta pedagógica, a saber, o ensino técnico integrado. Este pretende levar os/as alunos/as a vivenciarem um universo de ensino técnico profissionalizante que possibilite um conhecimento humanizado e contribua para as necessidades regionais que envolvem os Institutos Federais, em especial o Câmpus Amajari. Trato também do ensino médio indígena em Roraima e suas possíveis implicações para as escolhas dos estudantes macuxi que frequentam ou frequentaram o CAM. Por fim, aponto as opções de ensino superior para os/as estudantes indígenas, tendo em vista os conflitos que envolvem o afastamento de suas comunidades e suas consequências.

\subsection{Educação, trabalho e ensino integrado}

Para compreender as discussões que remetem à proposta pedagógica de ensino integrado para o ensino médio técnico profissionalizante, é preciso ter em mente que não se trata de uma única, havendo, conforme Bezerra (2017, p. 359), ao menos mais duas propostas de ensino para a educação profissionalizante. A primeira vem do sistema produtivo, que

\begin{abstract}
defende a educação profissional como estratégia do capitalismo de estado para atender às suas necessidades mais imediatas, haja vista o discurso da falta de mão de obra técnica. Logo, reivindica uma educação média fundada em concepções teóricas marcadas pelo imediatismo, pela racionalidade instrumental e pela flexibilidade na relação com o conhecimento.
\end{abstract}

Outra opção de ensino integrado, em sua maior parte defendida por Nosella (2015), seria a "proposta radical que defende a oferta de uma escola média unitária, não profissional, que proporcione a todos, indistintamente, o acesso ao conhecimento que rompa definitivamente com a sociedade dividida em classes” (BEZERRA, 2017, p. 360).

Levo em conta essas propostas educacionais e a lei de criação dos IFs, determinando que metade das matrículas devam ser no ensino integrado (BRASIL, 2008), para a devida compreensão do conceito de educação integrada, sendo necessária uma breve digressão histórica a respeito das leis criadas no Brasil para regulamentar o ensino médio.

Caminhando pelos textos de Marx e Gramsci, os/as autores/as Cantaluce (2012), Ciavatta (2014), Ciavatta e Ramos (2011), Santos e Nadaletti (2017), Saviani (2007) e Silva (2017) buscam a origem das desigualdades entre os grupos sociais desde a Antiguidade, passando pela Idade Média e chegando à Revolução Industrial. Com a introdução da tecnologia 
fabril, a necessidade de conhecimentos técnicos teria ocasionado a dualidade no ensino médio. A partir do desenvolvimento do capitalismo, ainda na educação básica, os grupos populares seriam encaminhados para o trabalho manual, técnico e profissionalizante e os membros das elites ficariam com o conhecimento geral e encaminhados para o ensino superior:

\begin{abstract}
Constatamos, portanto, que o impacto da Revolução Industrial pôs em questão a separação entre instrução e trabalho produtivo, forçando a escola a ligar-se, de alguma maneira, ao mundo da produção. No entanto, a educação que a burguesia concebeu e realizou sobre a base do ensino primário comum não passou, nas suas formas mais avançadas, da divisão dos homens em dois grandes campos: aquele das profissões manuais para as quais se requeria uma formação prática limitada à execução de tarefas mais ou menos delimitadas, dispensando-se o domínio dos respectivos fundamentos teóricos; e aquele das profissões intelectuais para as quais se requeria domínio teórico amplo a fim de preparar as elites e representantes da classe dirigente para atuar nos diferentes setores da sociedade. (SAVIANI, 2007, p. 8)
\end{abstract}

No Brasil, as leis republicanas que deram início à dualidade no ensino básico se consolidam no período Vargas, com a Reforma Capanema, que pretendia organizar e orientar o Ensino Secundário e o Ensino Industrial, com objetivos distintos para cada uma das modalidades, através das Leis Orgânicas de cada ensino. Essas Leis Orgânicas do Ensino Industrial e do Ensino Secundário, conjuntamente com a criação do Senai (Serviço Nacional de Aprendizagem Industrial) em 1942 e, em 1946, a criação do Senac (Serviço Nacional de Aprendizagem Comercial), e ainda a transformação das escolas de Artífices em Escolas Técnicas Federais, colocavam o ensino básico em separado do técnico, caracterizando o propedêutico para a formação geral das elites e o técnico para os trabalhadores, não havendo equivalência entre os cursos. Tal situação somente foi alterada nos anos de 1950, com as "Leis de Equivalência entre os cursos técnicos e o ensino secundário ou médio - parciais em 1950, 1953, 1959 e plena com a Lei de Diretrizes e Bases da Educação Nacional (LDB - Lei n ${ }^{\circ}$ 4.024/1961)" (CIAVATTA; RAMOS, 2011, p. 29-30).

O crescimento econômico ocorrido no período da ditadura civil-militar, marcadamente entre os anos de 1968 e 1973, ocasionou aumento da urbanização no país e uma consequente pressão por disponibilidade de mão de obra mais qualificada. Regulamentaram-se as profissões de técnico de nível médio com a Lei 5.524/68 e a Lei 5.692/71, tornando-se obrigatória a profissionalização para o Segundo Grau, como uma solução aos problemas de ordem econômica e social originados na carência de mão de obra, e como uma tentativa de eliminar o dualismo existente entre o ensino regular e o técnico (REGATTIERI; CASTRO, 2009, p. 1627). No entanto, essa lei acabou por reafirmar tal separação, pois, segundo Ramos (2017, p. 27), “a real função era a contenção do acesso dos filhos da classe trabalhadora ao ensino superior". Mais tarde, a Lei $\mathrm{n}^{\circ}$ 7.044/1982 cancelou o caráter compulsório do ensino técnico no então chamado Segundo Grau. 
Durante a década de 1980, a luta por democratização do país levou a discussões para a elaboração de uma nova Lei de Diretrizes e Bases para a Educação, que substituísse a lei 5.692/71. Almejava-se que o ensino médio incorporasse uma educação com características omnilaterais e politécnicas (CIAVATTA; RAMOS, 2011, p. 30), de embasamento marxista.

O conceito de omnilateral está relacionado à ideia de uma realidade totalizada em todos os seus elementos constitutivos: o trabalho, a ciência e a cultura. Essa relação se dá pela ideia de que os seres humanos se diferenciam dos demais seres vivos pela sua habilidade de produzir, ou seja, é através do trabalho que o homem e a mulher se desenvolvem e se constituem como tal. Segundo Saviani (2007, p. 154),

Se a existência humana não é garantida pela natureza, não é uma dádiva natural, mas tem de ser produzida pelos próprios homens, sendo, pois, um produto do trabalho, isso significa que o homem não nasce homem. Ele forma-se homem. Ele não nasce sabendo produzir-se como homem. Ele necessita aprender a ser homem, precisa aprender a produzir sua própria existência. Portanto, a produção do homem é, ao mesmo tempo, a formação do homem, isto é, um processo educativo. A origem da educação coincide, então, com a origem do homem mesmo.

Essa visão não entende o trabalho como apenas vinculado à empregabilidade e ao sustento dos grupos populares, mas como algo mais significativo para a existência humana, pois através do trabalho se realiza o processo de conhecimento da humanidade. Diante de suas necessidades e busca de sobrevivência, a humanidade foi aprendendo a transformar a natureza, desenvolveu sua capacidade de aprender e de criar elementos novos para melhorar e dar conforto à sua vida. Assim, nessa concepção o trabalho teria duas dimensões: a ontológica, na qual o homem e a mulher produzem sua existência e seu conhecimento, e a histórica, pois no sistema capitalista desenvolve-se em trabalho assalariado, "portanto, como categoria econômica e práxis diretamente produtiva” (RAMOS, 2008, p. 8).

Sob essas perspectivas de conferir especificidades próprias a cada uma daquelas
dimensões constitutivas da prática social que devem organizar o ensino médio de
forma integrada - trabalho, ciência e cultura - que entendemos a necessidade de o
ensino médio ter uma base unitária sobre a qual podem se assentar possibilidades
diversas de formações específicas: no trabalho, como formação profissional; na
ciência, como iniciação científica; na cultura, como ampliação da formação cultural.
Assim, nossa proposta é de que, respeitadas as normas do sistema de ensino, as
instituições pudessem acrescentar ao mínimo exigido para o ensino médio, uma carga
horária destinada à formação específica para o exercício de profissões técnicas, ou
para a iniciação científica, ou para a ampliação da formação cultural. Isto possibilitaria
o desenvolvimento de atividades relacionadas ao trabalho, à ciência e à cultura,
visando a atender às necessidades e características sociais, culturais, econômicas e
intelectuais dos estudantes. (p. 10)

Essa proposta atenderia à segunda característica do modelo de educação que estava sendo gestado nas discussões para elaboração da nova Lei de Diretrizes e Bases da Educação, 
que se esperava que fosse concluída com o fim do período ditatorial e o início da democratização, visando à construção do ensino médio com um viés politécnico.

Esse conceito não se relaciona com o modelo atual de diversidade de conhecimentos técnicos para melhor adaptação ao mundo contemporâneo, marcado por uma variedade de funções exigidas do trabalhador em um campo de atuação. Pretende

\begin{abstract}
estender ao ensino médio processos de trabalho reais, possibilitando-se a assimilação não apenas teórica, mas também prática, dos princípios científicos que estão na base da produção moderna. Esta era a concepção que alimentou o projeto de LDB do Deputado Otávio Elísio, que tinha como objetivo para o ensino médio, "propiciar aos adolescentes a formação politécnica necessária à compreensão teórica e prática dos fundamentos científicos das múltiplas técnicas utilizadas no processo produtivo" (Brasil, 1988, art. 35). (CIAVATTA, 2014, p. 5)
\end{abstract}

Assim são descritas as bases do que seria o chamado ensino integrado. A vinculação dessa educação à capacitação da classe trabalhadora daria início a um projeto de criação de uma escola unitária, fruto da concepção de que a educação é um direito de todos, buscando a formação intelectual e para o trabalho. Fica evidente que tal busca está associada à luta de classes travada dentro do sistema capitalista, em que a formação para o trabalho predomina sobre a formação intelectual do indivíduo. A escola unitária dentro de uma educação politécnica seria, antes de tudo, acessível para o trabalho, mas também para os conhecimentos sociais e culturais produzidos nas mais diferentes sociedades ao longo dos séculos. O/A estudante seria instruído em tal escola para a produção de riquezas materiais, mas também para uma busca existencial, dentro da sua formação humana.

Entretanto, a nova LDB, a Lei 9.394/96 aprovada no governo de Fernando Henrique Cardoso, deu outras características ao ensino médio e à educação profissionalizante, que desconfiguraram a proposta de ensino integrado.

A nova lei entende a educação com um sentido de preparação para a vida, o que, no entender de Ciavatta e Ramos (2011, p. 30), consistia em “desenvolver nas pessoas competências genéricas e flexíveis, de modo que elas pudessem se adaptar facilmente às incertezas do mundo contemporâneo". Ao mesmo tempo, a LDB trazia alguns benefícios ao ensino médio, tornando-o parte da educação básica. Contudo, ainda não o tornava obrigatório. Esse status só foi alcançado com a Emenda Constitucional 59/2009, a partir da qual estudantes de 15 a 17 anos foram beneficiados. Segundo Silva (2017, p. 74), “a LDB produz vários entrelaçamentos entre formação geral e formação profissional".

No entanto, a redação do texto legal é fluida, dando margem a interpretações dúbias. Para Silva, essa condição do texto possibilitou a publicação do decreto 2.208/97, que novamente determinou a separação entre ensino profissionalizante e ensino regular. Esse decreto foi 
motivador de uma série de críticas à postura neoliberal do governo de Fernando Henrique Cardoso, compreendendo-se que:

As relações entre transformações tecnológicas e necessidade de mudanças na educação escolar caracterizam uma percepção linear e determinista sobre esta última, como se a formação humana se restringisse exclusivamente a formar para o mercado de trabalho, e "circunscreve uma visão parcial e limitada do papel da escola, pois a restringe à formação para o mercado e à observância à lógica mercantil". (SILVA, 2017, p. 75)

Nesse sentido, a educação profissionalizante passou a ser vista como uma alternativa ao ensino superior para os grupos populares. A ideia de a empregabilidade estar vinculada à necessidade de qualificação e requalificação atribuía a responsabilidade do desemprego aos próprios trabalhadores, destinando a periferia da produção e a precarização do trabalho para os/as estudantes e trabalhadores/as do ensino técnico. "A pedagogia das competências, nesse caso, visava à adaptação psicofísica do trabalhador a tais condições, esvaziando a formação de conteúdos científicos que embasava a perspectiva da consolidação de uma profissão" (CIAVATTA; RAMOS, 2011, p. 30-31).

A luta pela revogação desse decreto teve efeitos no governo Lula (2002-2010), quando foi assinado o Decreto 5.154/2004, que, em linhas gerais, revogou o anterior. Contudo, Frigotto, Ciavatta e Ramos (2005, p. 1088-1095) exibiram um direcionamento posterior ao decreto, que, na visão dos autores, recolocava uma contradição, pois consideravam que os programas como Proeja, Escola de Fábrica e Projovem, na prática, reforçavam a separação entre o ensino técnico e o regular.

\footnotetext{
A manutenção da validade das Diretrizes Curriculares Nacionais para o Ensino Médio e para a Educação Profissional, após a edição do novo decreto, dá continuidade à política curricular do governo anterior, marcada pela ênfase no individualismo e na formação por competências voltadas para a empregabilidade. Reforça-se, ainda, o viés adequacionista da educação aos princípios neoliberais. Neste particular, reafirma-se um dos fetiches ou uma das vulgatas, insistentemente afirmada nos oito anos de Governo Fernando Henrique Cardoso, de que no Brasil não havia falta de empregos, mas de "empregáveis". (FRIGOTTO; CIAVATTA; RAMOS, 2005, p. 1095)
}

O ensino médio integrado profissionalizante encontrou falta de adesão dos sistemas de ensino estaduais e, excetuando Paraná, Santa Catarina e Espírito Santo (FRIGOTTO; CIAVATTA; RAMOS, 2005, p. 1092), acabou restrito às escolas técnicas federais, especificamente aos Cefets (Centros Federais de Educação Profissional e Tecnológica). Apenas o Paraná se arriscou a implementar o ensino médio integrado (EMI) sem o aporte financeiro do governo federal, que demorou a implantar as medidas para a expansão e o apoio econômico às secretarias estaduais de educação interessadas de outros estados.

Ainda em 2003 foi criado o Fórum Nacional de Educação Profissional e Tecnológica, reunindo diversas entidades sindicais e representantes da sociedade civil, que iniciaram as 
discussões que dariam origem ao texto "Pacto pela Valorização da Educação Profissional e Tecnológica", em agosto de 2004, e, posteriormente, às "condições para a expansão da rede Federal de Educação Profissional e Tecnológica e o surgimento dos Institutos Federais de Educação, Ciência e Tecnologia, com a Lei $\mathrm{n}^{\circ}$ 11.892, de 29 de dezembro de 2008" (BEZERRA, 2017, p. 365-366).

A criação dos IFs mantinha as características necessárias para a implantação do modelo de ensino integrado profissionalizante, pois os campi criados reuniam professores especializados e qualificados e estrutura multicampi, com ênfase no tripé formado por ensino, pesquisa e extensão. Buscavam uma educação escolar integrada ao ensino superior com cursos tecnológicos e licenciaturas. Contavam com laboratórios, bibliotecas equipadas, alojamentos para os estudantes, políticas de permanência estudantil, bolsas de pesquisa e extensão e transporte para os estudantes (RAMOS, 2017, p. 28-29; REIS JR., 2017, p. 68-76).

A expansão da rede federal foi intensa. Entre 1909 e 2002, foram construídas 140 escolas técnicas no país. Entre 2003 e 2016, o Ministério da Educação concretizou a construção de mais de 500 novas unidades referentes ao plano de expansão da educação profissional, totalizando 644 campi em funcionamento.

São 38 Institutos Federais presentes em todos os estados, oferecendo cursos de qualificação, ensino médio técnico profissionalizante integrado nas modalidades concomitante e subsequente, ensino a distância e ainda cursos superiores de tecnologia e licenciaturas.

Conforme já mencionei, a lei de criação dos Institutos Federais determinou que 50\% das vagas para o ensino médio fossem em sistema integrado, e as demais seriam divididas entre subsequente e concomitante (SANTOS; NADALETTI, 2017, p. 90). Na região Norte, havia, em 2008, 8.369 matrículas no ensino médio integrado. Em 2015, houve um salto para 24.229 matrículas. No mesmo ano, registrou-se um aumento de $60 \%$ das matrículas na rede federal com relação ao ensino médio integrado na região Norte, que se caracterizou como a que mais obteve matrículas nessa modalidade na rede federal de todo o país (SANTOS; NADALETTI, 2017, p. 93-94).

O Instituto Federal em Roraima tem a maioria das matrículas no ensino médio integrado. Especialmente no CAM, 100\% das vagas presenciais são de ensino médio integrado. Porém as dificuldades de implantação desse projeto ainda são grandes. Como na maioria dos IFs, há obstáculos à efetivação da proposta pedagógica. Os corpos docentes, gestores e técnicos educacionais não dispõem de suficiente qualificação nesse tema, e o pouco tempo de existência dos IFs não promove o entendimento e implantação desse conceito (SILVA et al., 2017, p. 492). 


\subsection{O CAM e os estudantes no ensino médio de Roraima}

Em 2020, o IFRR em Amajari completa dez anos de existência com sua sede na Vila Brasil. Há ali uma escola municipal com ensino infantil e fundamental I, além da Escola Estadual Ovídio Dias, com fundamental II e ensino médio, onde o CAM iniciou suas atividades até obter sua sede própria.

O câmpus teve o mesmo diretor-geral desde a criação. Em 2016 este nomeou para a direção de ensino uma professora wapichana, mestre em educação, oriunda do Instituto Insikiran $^{30}$, tornando mais acessível o diálogo e possibilitando alterações no relacionamento com as comunidades indígenas da região. Sob sua gestão, a instituição ofertou um curso de alternância ${ }^{31}$ em Agropecuária para indígenas macuxi da comunidade do Contão, na região do Surumu, município de Pacaraima, dentro da Terra Indígena São Marcos. Também organizou eventos internos para discussão da diversidade cultural existente no câmpus e possibilitou ações direcionadas para as comunidades próximas à instituição.

Essa mesma diretora de ensino wapichana tinha forte probabilidade de se tornar a próxima diretora-geral do Câmpus Amajari, pois o processo eleitoral que se encerraria em setembro de 2020 contava apenas com o seu nome como candidata à eleição para o cargo. O câmpus, de maioria discente indígena, teria uma mulher indígena na sua direção-geral. A situação era emblemática, e cheia de expectativas.

Assim como é comum nos campi do Instituto Federal espalhados pelo país, o CAM tem cursos de ensino médio integrado, subsequente, concomitante, em regime de alternância e em $\mathrm{EaD}$ (ensino a distância); tem ainda um curso superior, em Aquicultura, com três turmas. Nos cursos de Agropecuária e Aquicultura, a maioria de estudantes é indígena, havendo também venezuelanos/as e não indígenas.

30 O Instituto Insikiran de Formação Superior Indígena é vinculado à Universidade Federal de Roraima. Foi criado para atender às demandas das comunidades indígenas de Roraima representadas por suas organizações, com o objetivo de viabilizar a formação profissional, de modo específico, diferenciado e intercultural. Disponível em: http://ufrr.br/insikiran/index.php?option=com_content\&view=article\&id=60\&Itemid=268. Acesso em: 23 jul. 2018.

31 O regime de alternância consiste em um sistema de ensino em que os/as alunos/as permanecem um tempo em suas comunidades executando projetos elaborados pelos/as professores/as e discentes, que deveriam ter relação com o seu universo de vivência e os conteúdos desenvolvidos na sala de aula. O CAM tem essa modalidade de ensino desde a sua fundação. O diretor do câmpus, George Sterfson, realizou pesquisa de mestrado, na área de Educação, sobre um dos primeiros cursos de alternância do CAM, que envolveu estudantes da comunidade Guariba, a 50 km do câmpus. Iniciou-se em 2017 o primeiro curso de alternância com estudantes indígenas macuxi em sua totalidade, a maioria da comunidade do Contão, na TI Raposa Serra do Sol. (Entrevista ao autor, fev. 2018). 
Em 2008, foram realizadas três audiências públicas com participação das comunidades indígenas, bem como não indígenas e moradores do município de Amajari, para verificar os interesses por cursos a serem oferecidos no Câmpus Amajari.

De acordo com Lopes (2015, p. 63-64), as sugestões das comunidades giraram em torno de cursos voltados para áreas que não tinham total relação com o ambiente rural. $\mathrm{O}$ curso que esteve na preferência da maioria das comunidades que participaram das audiências públicas foi o de Técnico em Enfermagem. Outros preferidos foram Turismo, Educação, Informática, Agropecuária, Agronomia, Veterinária e Zootecnia. O curioso foi a falta de interesse, à época, no curso de Aquicultura, que depois acabou se tornando o principal do câmpus, ganhando também um curso superior.

A presença da instituição na cidade de Amajari, segundo o diretor-geral, foi dada pela dificuldade de instalação na cidade de Pacaraima, que seria a primeira opção. No entanto, Pacaraima está localizada na TI São Marcos, que, por ser em área contínua, proíbe a presença de não indígenas, sendo razão de disputa entre as lideranças indígenas e o governo estadual. Posteriormente, pensou-se em utilizar a estrutura do Centro Indígena de Formação e Cultura Raposa Serra do Sol, mas o CIR, que administrava o Centro, não aceitou ceder a direção ao Instituto. A opção por Amajari se deu, ainda de acordo com o diretor-geral, por questões estratégicas. Amajari se localiza entre as cidades de Pacaraima (fronteira com a Venezuela) e Alto Alegre; está a $50 \mathrm{~km}$ da capital, Boa Vista, e próximo das duas principais terras indígenas de Roraima: Raposa Serra do Sol e São Marcos. O diretor-geral assim descreve o processo que levou à escolha de Amajari como sede:

O Amajari está no centro. Perto de Alto Alegre, Pacaraima, está próximo de tudo, a Raposa Serra do Sol, que já estava nessa questão. E aí, nós podemos trazer os alunos dessas comunidades todinhas, e o Uiramutã, Normandia, porque até [de] Normandia, hoje, nós temos alunos. Então, se decidiu que o melhor foi fazer em Amajari, porque ficaria no centro, e traria todos..$^{32}$

A instituição estimulou uma mudança no direcionamento dos/as jovens estudantes indígenas, que, anteriormente, somente contavam com ensino médio regular nas escolas indígenas de suas comunidades. Existia apenas um curso técnico diferenciado em Agropecuária, no Centro Indígena de Formação e Cultura Raposa Serra do Sol. Para cursarem ensino técnico profissionalizante, tinham então que se deslocar até a cidade de Boa Vista. A instalação do câmpus também causou mudanças na Vila Brasil, incrementando o comércio e o setor imobiliário da localidade, que não dispunha de acomodação temporária adequada para 
os/as servidores/as. Estes/as passaram a se deslocar de Boa Vista para trabalhar no câmpus, ou até mesmo a residir na Vila, como era o caso de muitos/as que vieram de outros estados. Assim, o CAM, por si só, já causava uma movimentação local. Segundo depoimentos de tuxauas da região, o câmpus era muito esperado pelos indígenas das comunidades próximas.

O tuxaua da comunidade Aningal (a aproximadamente $30 \mathrm{~km}$ do CAM), da etnia Sapará, pai de dois alunos/as e também egresso do Câmpus Amajari quando sua sede era na Escola Estadual Ovídio Dias, participou do processo de discussão da implantação do CAM. Ele afirmou $^{33}$ que a instalação dessa instituição na região era um anseio de várias lideranças, pois esperavam que possibilitasse uma perspectiva de desenvolvimento das comunidades e qualificação dos jovens, que, assim como ele, se deslocavam até a instituição com muitas dificuldades. A comunidade, apesar de relativamente próxima, nunca teve muitos estudantes no CAM, pois não contam com transporte escolar.

Observando a decisão final que levou à escolha do curso de Agricultura, considerandose os pareceres técnicos e uma "possível demanda da região", percebe-se uma certa adequação do interesse das audiências públicas às condições disponíveis do IFRR. Levando-se em conta que a sede ainda não estava concluída, e que o curso seria oferecido nas dependências da escola estadual Ovídio Dias, que contaria com pouca estrutura, e ainda o fato de que o câmpus Amajari é considerado rural, a opção pelo curso de Agricultura desconsiderou o desejo das comunidades manifestado nas audiências públicas.

Quando da instalação, em 8 de outubro de 2010, com sede provisória na Escola Ovídio Dias, o CAM ofertou 70 vagas para o curso Técnico em Agricultura Subsequente ao Ensino Médio (diurno e noturno, com retornos aos sábados para as atividades práticas). Apenas em 2012 começaram as turmas integradas ao ensino médio, sendo 70 vagas das 140 ofertadas em regime de alternância (IFRR, 2015, p. 10).

No segundo semestre de 2012, iniciaram-se as aulas no novo prédio, e somente em 2013 iniciaram-se o curso Técnico em Agropecuária (Integrado ao Ensino Médio e Subsequente) e, pelo Programa Nacional de Acesso ao Ensino Técnico e Emprego - Pronatec, os cursos de Apicultor, Auxiliar Administrativo e Operador de Computador (p. 10).

O CAM tem uma construção singular em uma região com precariedades comumente atribuídas às escolas públicas do país. Dispõe de oito salas de aula, todas com um televisor de 29 polegadas e ar-condicionado. São quatro laboratórios, tanques de piscicultura, uma 
biblioteca, restaurante, alojamentos feminino e masculino com 40 vagas cada um, e uma casa para o coordenador do alojamento. Há também um ginásio poliesportivo e uma academia. São 45 técnicos/as administrativos/as com formações variadas. Embora com fraca conexão, há acesso de Internet por wi-fi. De todo modo, a instituição impressiona estudantes indígenas e não indígenas por seus recursos e pelos benefícios que proporciona.

Todos/as os/as 98 alunos/as vivendo no alojamento tinham direito a três refeições diárias. O restante do corpo discente tinha direito apenas ao almoço. $\mathrm{O}$ restaurante foi terceirizado e, até 2018, as queixas de estudantes e servidores/as eram muitas, principalmente sobre a qualidade das refeições. A partir da troca do terceirizado, houve relatos de melhora.

Em conversas com um ex-coordenador da $\mathrm{Caes}^{34}$ (Coordenação de Assistência ao Estudante), foram descritas as ações para promover o acesso, a permanência e o êxito dos/as estudantes. Dentre essas ações, era fornecido em 2019 auxílio-transporte diário a 115 estudantes de localidades próximas ao câmpus (as comunidades indígenas Três Corações, Araçá, Guariba, Mangueira, Mutamba e a Vila do Tepequém, no município de Amajari) e transporte a estudantes de alternância, da região do Contão. Havia auxílio-alimentação para 180 estudantes e auxíliomoradia para 110 alunos/as, somando 405 pessoas atendidas em acolhida. Em determinadas situações, realizavam-se visitas para verificar motivos de ausência. A equipe multidisciplinar da Caes foi composta por uma assistente social, uma psicóloga (que, no primeiro semestre de 2019, estava afastada) e um enfermeiro, que chegou em 2018.

A coordenação pode ser ocupada por qualquer servidor/a que seja indicado/a e aceite. Quem integra a Caes participa das reuniões de pais, mães e responsáveis, conselho de classe e pedagógicas. Até recentemente, a coordenação era exercida por um docente; passou, então, para um técnico educacional.

Os cortes de orçamento dificultaram as ações da Caes e, sem esses serviços, dificilmente o número de estudantes indígenas atendidos/as se manteria. Segundo dados da Caes o orçamento se manteve estável desde 2019, mantendo os mesmos valores em 2020. Além disso, a Caes tinha ações para melhorar a convivência e dar assistência a estudantes, alojados/as ou não. Ocorreram campanhas de vacinação, palestras sobre diversos temas de saúde e questões de relacionamentos entre os adolescentes, e atividades recreativas envolvendo os/as alunos/as alojados/as. 
Entre docentes havia 39 efetivos/as e 9 substitutos/as. Tinham formação em doutorado (14), mestrado (16), especialização (12) e graduação $(6)^{35}$. Os/as professores/as da área comum $^{36}$ e os/as da área técnica formavam grupos e, raramente, faziam um trabalho interdisciplinar ${ }^{37}$. Uma vez que o câmpus é voltado para a temática rural, a maioria dos projetos de extensão e de pesquisa se concentra na área técnica. Em 2015, dentre 34 projetos de extensão, apenas dois tratavam de temática indígena. Em 2016, dos 26 projetos, apenas um. Em 2017, dos sete projetos de extensão com bolsa, apenas um enfocava indígenas. Em 2018 somente dois trataram desses temas e, em 2019, dos 19 projetos de extensão aprovados para o Câmpus Amajari, houve apenas um com tema relacionado às comunidades indígenas. E os/as alunos/as aprovados/as também recebiam uma bolsa para desenvolver projetos que tivessem relação com as comunidades que circundam o câmpus, normalmente orientados/as por um/a docente ou técnico/a educacional. O projeto poderia ser desenvolvido pelos/as alunos/as e auxiliado pelos/as servidores/as ou vice-versa.

Havia ainda os Programas Institucionais de Bolsa de Iniciação Científica e Tecnológica (Pibict), que em 2016 aprovou seis bolsas, e concedeu cinco em 2017, não havendo nenhum projeto de pesquisa com bolsa tendo temática nas comunidades indígenas. Também tinha lugar o Pipad (Programa Institucional de Incentivo à Pesquisa Aplicada Docente), que aprovou quatro bolsas em 2016, sete em 2017, seis bolsas em 2018 e sete bolsas em 2019, não havendo em nenhuma delas a temática indígena. Essas considerações buscam mostrar a dificuldade de docentes e da instituição em se interessarem por esse assunto, no estado com o maior número de indígenas por número de habitantes, e no câmpus com mais estudantes indígenas do IFRR.

A falta de interesse ou o desconhecimento podem estar associados à origem dos/as servidores. Tanto técnicos/as administrativos/as quanto docentes vêm de regiões variadas do país, como São Paulo, Rio de Janeiro, Espírito Santo, Minas Gerais, Paraíba, Bahia, Ceará, Pará, Amazonas e outros estados. Trazendo visões citadinas de grandes centros, algumas pessoas esperavam um tipo de aluno/a que não encontravam em Amajari. Muitos/as docentes

35 Dados fornecidos em uma apresentação da gestão no início do ano letivo (fevereiro) de 2019.

36 Disciplinas que compõem a parte básica curricular, como Matemática, Física, História etc.

37 Apesar de a coordenação pedagógica propor constantemente que se realizem ações interdisciplinares, e de formações no início dos semestres e no retorno das férias de julho tendo convidados/as professores/as formadores/as da UFRR ou de campi da capital Boa Vista, que fortalecem o discurso da interdisciplinaridade, a resistência por parte de professores/as ainda se mantém. A facilidade de trabalhar em sua própria disciplina ignorando as demais parece seduzir mais do que a ação interdisciplinar. 
eram da área técnica, e não haviam precisado dominar conhecimentos pedagógicos para serem aprovados/as nos concursos, dificultando ainda mais o entendimento dos desafios na sala de aula. Além disso, o CAM era visto como um câmpus de passagem, ao qual a maioria dos/as servidores/as chegava com a expectativa de conseguir "remoção" dentro de um curto período de trabalho, o que resultava em dificuldades na elaboração de projetos de longo prazo.

Em reuniões pedagógicas ou em conversas na sala dos professores, em 2015 e 2016, quando atuei como docente, notei que havia por parte dos/das docentes em geral um desconhecimento a respeito das características dos/as estudantes indígenas e de suas dificuldades específicas, evidenciado em comentários relacionados à timidez dos/as alunos/as, na ignorância das características das suas etnias ou na insistência em avaliá-los/as de acordo com instrumentos baseados somente em provas escritas, por exemplo. Embates envolvendo a coordenação pedagógica para conter desejos de reprovações alimentadas por avaliações escritas eram constantes.

A matrícula era semestral. Dada a inexistência de um material didático produzido pela instituição, cada docente produz seu próprio, seja livro didático, apostila ou uma mistura de ambos. As avaliações que, no cotidiano, podiam variar em dois ou cinco instrumentos, deveriam seguir, segundo o documento Organização Didática, pelo menos dez elementos para composição da nota final do semestre:

I - Observação contínua; II - Elaboração de portfólio; III - Trabalhos individuais e/ou coletivos; IV - Avaliações escritas; V - Resolução de exercícios; VI Desenvolvimento e apresentação de projetos; VII - Relatórios; VIII - Avaliações práticas; IX - Avaliações orais; X - Visita técnica com relatório das atividades desenvolvidas. (IFRR, 2018, p. 40)

Além do conhecimento técnico, também deveriam ser consideradas pelos/as docentes na avaliação os seguintes critérios: "I- Comportamento; II- Assiduidade e pontualidade; IIIProatividade; IV- Valores morais e éticos; V- Espírito de solidariedade, companheirismo, respeito ao outro e ao bem comum".

No entanto, as avaliações se restringiam a trabalhos em grupos, seminários, relatórios de visitas técnicas e avaliações escritas. Sendo assim, as características específicas dos/as estudantes indígenas e suas visões de mundo não conseguiam ser compreendidas com esses instrumentos de avaliação - aliás, dificilmente se consegue avaliar os/as alunos/as não indígenas dessa maneira. Ghanem (2006) também questiona o conceito de avaliação que utilizamos:

Qual o objeto da avaliação, então? Os alunos. Em que termos? Em termos da aprendizagem que demonstrarem, comparada à aprendizagem esperada como efeito do ensino. Os próprios alunos chegam a perguntar com naturalidade: "Professora, como a senhora vai nos avaliar?". Dado o predomínio dessa visão de educação e de 
avaliação, a educação escolar fica completamente destituída de sentido ou assume unicamente o sentido de uma rotina progressiva de transmissão de saberes, apartada das aspirações e inquietações daqueles que a colocam em prática. A escola não é concebida como uma organização que intervém em determinado lugar, apenas como um estabelecimento que pode estar em qualquer lugar, pois suas práticas educativas são indiferentes ao lugar e às pessoas que ali vivem. No litoral ou na serra, na capital ou no interior, na zona rural ou urbana, no centro ou na periferia, nada dos problemas econômicos, culturais ou políticos da vida das pessoas constitui o ponto de partida das práticas educativas escolares. Por isso, a avaliação continua renitentemente a avaliação que o professor faz de cada aluno, segundo aquilo que ele identifica ter o aluno aprendido (daquilo que se ensinou ou se pretendeu ensinar). (2006, p. 158)

Era escassa a reflexão sobre a diversidade cultural, assim como era incerto o respeito às etnias do estado, tanto entre servidores/as quanto entre estudantes não indígenas.

Em 2017, implantou-se uma turma de alternância em Agropecuária (OLIVEIRA, 2020) formada totalmente por alunos/as macuxi vindos da região do Contão, na TI Raposa Serra do Sol. A turma dispôs de uma coordenação específica, pois o projeto de alternância exige uma atuação diferenciada tanto dos docentes quanto dos discentes e da comunidade. Em conversas com os/as estudantes dessa turma, foram relatadas dificuldades para essas atividades acontecerem corretamente, seja porque os/as estudantes perdiam o ritmo estando afastados do ambiente escolar (e, segundo disseram alguns/algumas, distraíam-se com suas atividades cotidianas), seja porque as atividades propostas não ultrapassavam a dimensão de uma lição de casa, desprovida de relação com a realidade local.

O trabalho prático foi realizado em uma escola estadual no Contão, apresentada no item 1.6 do Capítulo 1. No entanto, em duas visitas feitas à unidade escolar, notei dificuldades estruturais relacionadas com a manutenção da horta. Havia problemas com o fornecimento de água, por meio de uma bomba, que estava prejudicando o desenvolvimento do projeto, mesmo com o empenho de docentes em dar suporte técnico aos/às alunos/as. Além disso, os/as discentes eram oriundos/as de comunidades diversas, distantes do Contão, e não eram acompanhados/as em suas próprias comunidades.

Seriam atendidas 16 comunidades: Contão, Canta-Galo, Pedra do Sol, Taxi I, Taxi II, Surumu, Barro, Maravilha, São Bento, Placa, Olho D’Água, Kaipîta, São Mateus, Triunfo, São Luiz e Achado. Entretanto, 8 comunidades enviaram nomes de estudantes para participarem dessa turma. Foram as comunidades Contão, Placa, Surumu, Canta-Galo, São Luiz, Maravilha, São Bento e São Jorge, todas na Terra Indígena Raposa Serra do Sol. 


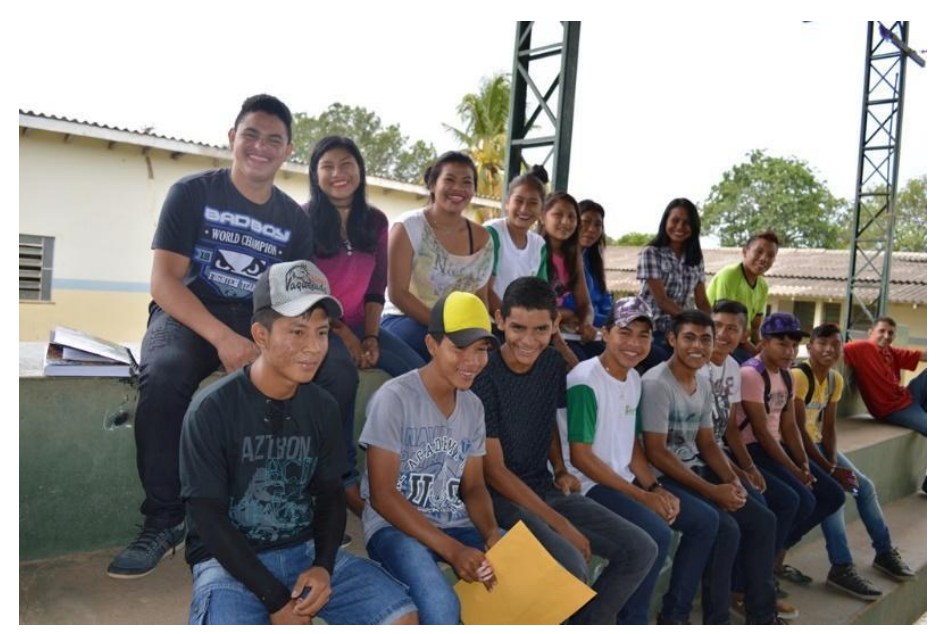

Fonte: Rebeca Lopes. 2017.

As atividades desenvolvidas deveriam apresentar conexão entre os conteúdos e aquilo que era feito na comunidade no período conhecido como tempo comunidade, em que os/as discentes permanecem por 15 dias nas suas regiões de origem. As famílias, a liderança e as organizações indígenas precisariam estar muito envolvidas com o projeto e, especialmente, ter espaço para participarem das decisões do curso.

Existem casos de protagonismo, em que o trabalho de base foi realizado de forma envolvente e as famílias, as organizações sociais, desde o início, tiveram a iniciativa e protagonizaram o processo. Nestes casos, setores como as Igrejas, Sindicatos, poder público etc. são considerados imprescindíveis, mas cada um deve se colocar no seu devido lugar, como parceiro e não como "dono" da iniciativa. A participação é uma construção permanente. Assim como a formação é um imperativo para os formadores, a participação é uma necessidade em igual peso para as famílias poder conhecer e aderir à proposta de uma forma militante. (BEGNAMI; BURGHGRAVE, 2012, p. 268)

Essa participação não se efetivou durante o processo de desenvolvimento do curso.

Após a formatura dessa turma de alternância, pude verificar, em entrevista com o atual diretor da Escola Estadual José Marcolino ${ }^{38}$, a permanência de cinco alunos pertencentes à comunidade do Contão em suas comunidades. Um deles foi escolhido pelo tuxaua para trabalhar com o capataz ${ }^{39}$ da região, auxiliando na organização do trabalho agrícola; e os demais, ajudando suas famílias nas roças locais. Do Contão vieram 15 alunos/as que pertenceram a essa turma. Os/as demais foram para Boa Vista tentar uma vaga em algum curso superior ou buscar emprego, ou estavam sem ocupação em suas comunidades.

38 Entrevista ao autor, fev. 2020.

39 Um indígena escolhido pelo tuxaua para organizar o trabalho agrícola da comunidade e do rebanho de gado. 
A empregabilidade dos egressos do IFRR, segundo um professor indígena ${ }^{40}$ da Escola Estadual Indígena Tuxaua Silvestre Messias, no Surumu, já estava sendo tema das reuniões das organizações indígenas.

Figura 20 - Formatura do curso técnico em alternância em Agropecuária, na Escola Estadual José Marcolino, no Contão

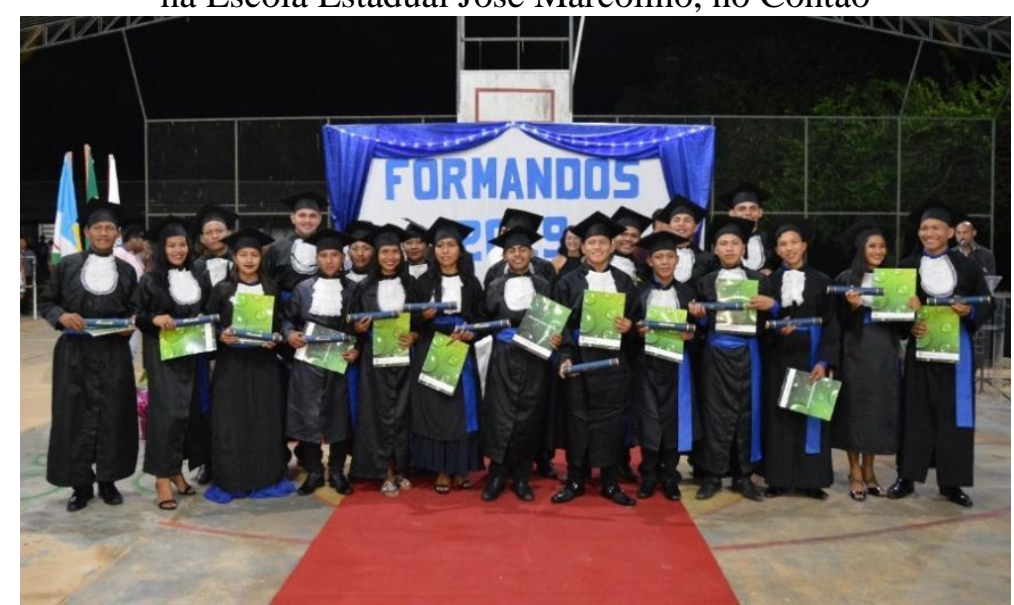

Fonte: Nenzinho Soares/IFRR. 14 nov. 19.

Desde 2016, ampliaram-se as discussões sobre a diversidade cultural e as temáticas indígenas, ocasionadas pelas mudanças na Direção de Ensino bem como pelo estreitamento das relações com as comunidades indígenas atendidas pela instituição. Porém ainda eram incipientes as ações pedagógicas que pudessem facilitar a aprendizagem de estudantes indígenas.

Joelma Fernandes de Oliveira, pedagoga do CAM, analisou a instituição em seu livro sobre gestão e interculturalidade (OLIVEIRA, J., 2019). Entrevistou seis gestores e um deles descreveu o que se realizava no câmpus para sensibilizar os docentes que "não dão a mínima" para as dificuldades dos/as alunos/as indígenas.

Fomento à formação continuada da equipe: em parceria com a Coordenação Pedagógica são realizados encontros pedagógicos, grupo de estudos, seminários entre outras atividades visando à formação da equipe e sua interação. Além disso, os docentes e técnicos são incentivados e apoiados a participarem de eventos/cursos relacionados a sua área promovidos pela Instituição e por outras. Apoio às iniciativas dos profissionais: todos os profissionais que trabalham no setor têm apoio para realizarem atividades/ações propostas pelos mesmos. E Autonomia para que os profissionais desenvolvam atividades e ações que contribuam com o processo formativo dos discentes. (p. 73)

Algumas atividades realizadas no IFRR-CAM foram voltadas para o que é chamado de socialização e integração entre os/as alunos/as, tais como o projeto de extensão "Socializando

40 Conversa informal na unidade escolar. 
com música" (que visava a estimular, por meio da música indígena brasileira, venezuelana e regional, o convívio e a integração dos alunos) e o "Registro das músicas tradicionais indígenas", projeto de pesquisa que tem como objetivo recuperar músicas indígenas, envolvendo transcrição em partituras, traduções para o português e gravações em áudio. A partir desses projetos, apresentava-se o parichara, uma atividade musical e de dança tradicional indígena dos povos de Roraima, praticado em um círculo formado por casais, no qual todos ficam com braços entrelaçados (OLIVEIRA; LIMA, 2019, p. 329).

Também foi realizado um projeto de práticas pedagógicas inovadoras, INOVA/IFRR, com os/as alunos/as dos primeiros anos do ensino médio técnico integrado em Agropecuária e Aquicultura, no ano de 2017. Denominava-se "Cordel Intercultural: Produção Literária do/no IFRR Câmpus Amajari”. Resultou em um livro ${ }^{41}$, composto de textos poéticos produzidos nas aulas da disciplina de Português e de Nivelamento ${ }^{42}$ de Língua Portuguesa. Os textos retratam o cotidiano e os lugares em que os/as estudantes das turmas 125, 126 e 127 viviam, sendo muitos/as deles/as indígenas. Ainda na disciplina de Português e com o envolvimento da área de Educação Física, foi organizado com os/as alunos/as dos primeiros anos, em 2019, um jornal com os acontecimentos e projetos de pesquisa e extensão desenvolvidos no $\mathrm{CAM}^{43}$.

Essas atividades, contudo, não eram representativas da maior parte do que se fazia no CAM, em geral alheio ao grande contingente de estudantes indígenas e ao contexto local.

Em conversa com a diretora de ensino, manifestou-se um interesse em estabelecer maior diálogo com as organizações indígenas, para que contribuíssem com sugestões e trocas de conhecimentos entre a instituição e os profissionais indígenas que atuam nessas entidades. Trata-se de um caminho adotado por outro câmpus que mantém características semelhantes: após várias tentativas frustradas de lidar com as populações majoritariamente indígenas que frequentavam o câmpus São Gabriel da Cachoeira do Instituto Federal do Amazonas (Ifam), a diretoria desse instituto passou a atuar de forma conjunta em ações educativas com as organizações indígenas, culminando na criação de um curso de Licenciatura Intercultural na instituição (RAMOS SOUZA, 2018).

41 IFRR. Interculturalidade em versos. Amajari: IFRR Câmpus Amajari, 2018. Foi um livro produzido internamente pelos alunos e alunas que participaram das aulas de Língua Portuguesa.

42 Aulas de reforço de Língua Portuguesa para alunos que apresentam dificuldade nos primeiros anos, realizadas no contraturno.

43 Disponível em: https://folhabv.com.br/noticia/CIDADES/Interior/Jornal-produzido-por-alunos-sera-lancadonesta-quarta/57824. Acesso em: 4 out. 2019. 


\subsection{Ensino médio indígena em Roraima}

No universo recheado de idas e vindas da legislação do ensino médio técnico profissionalizante brasileiro, como se insere o ensino médio vivenciado pelos/as indígenas no estado de Roraima? E como os/as estudantes macuxi do CAM vivenciam a experiência do ensino médio profissionalizante? A pesquisa que realizei permitiu formular algumas respostas.

No Brasil, em 2015, havia 8.074.881 matrículas no ensino médio (SANTOS; NADALETTI, 2017, p. 93), confirmando-se a tendência de queda que vinha se esboçando entre os anos de 2005 e 2012, uma vez que, em 2005, havia 10.637.139 matrículas no total de todas as modalidades do ensino médio, chegando-se em 2012 a 10.262.932 (REIS JR., 2017, p. 102). Embora se caracterize uma redução no número de estudantes, houve aumento nas matrículas do ensino profissionalizante e, especificamente, no ensino médio integrado (SANTOS; NADALETTI, 2017, p. 94-95).

De 500.133 habitantes de Roraima ${ }^{44}$, o número de jovens entre 15 e 17 anos, faixa etária correspondente ao ensino médio obrigatório, era de 31.368 , equivalentes a $6,46 \%$ da população total. Entre esses/as jovens, 51,60\% eram homens e 48,40\%, mulheres. Na população do estado, $72,4 \%{ }^{45}$ se autodeclararam negros e pardos e 5\%, “outros" (amarelo, indígena e não declarado). Dados de 2006 estimaram 64.796 indígenas pertencentes às nove etnias existentes (REPETTO, 2006, p. 8).

Entre os jovens de 15 a 17 anos, os dados étnicos também não eram muito diferentes das demais faixas etárias da população, pois 73,09\% se declararam negros e pardos e 11,90\% estavam na categoria "outros". Das mulheres entre 15 e 17 anos, 1.784 (12,66\%) já tinham filhos e 3\% eram responsáveis pelos seus domicílios (INSTITUTO UNIBANCO, 2019, p. 12-17).

O trabalho estava presente desde cedo na vida de muitos/as jovens. Alguns/algumas o acumulavam com os estudos e outros/as deixavam de estudar para somente trabalhar. Segundo o Instituto Unibanco (2019, p. 18), entre roraimenses de 15 a 17 anos, 17,87\% estavam fora da

\footnotetext{
44 Dados obtidos pela Pnad 2014, recolhidos no site do Observatório da Educação. Disponível em: https://observatoriodeeducacao.org.br/wp-content/uploads/2017/03/Panoramas_RORAIMA.pdf. Acesso em: 19 set. 2019.

${ }^{45}$ Em Roraima, segundo o censo de 2010, a população negra era de 26.364 pessoas e os que se autoidentificaram como pardos somaram 275.908 pessoas. Segundo o Estatuto da Igualdade Racial é considerado negro todo aquele que se autodeclara negro ou pardo. O Instituto Unibanco utiliza de dados do IBGE e da PNADC de 2019. Ver Folha WEB. Negro é invisível em Roraima, diz professora. 20/11/2014. Disponivel em: https://folhabv.com.br/noticia/CIDADES/Capital/Negro-e-invisivel-em-RR--diz-professora/2404. Acesso em: 30 nov. 2020.
} 
escola, $13,05 \%$ não trabalhavam nem estudavam, 22,36\% trabalhavam $(17,54 \%$ conciliavam o trabalho com os estudos, mas $4,82 \%$ se dedicavam exclusivamente ao trabalho) e $64,59 \%$ conseguiam se dedicar exclusivamente aos estudos.

Havia 785 escolas públicas, 6 das quais em Amajari. Das 480 estaduais, 257 eram escolas indígenas e 223 escolas eram não-indígenas em 2016 (VOLTOLINI, 2018, p. 58), e 300 pertenciam a áreas rurais, fazendo Roraima ser o estado da Federação com o maior número de escolas em áreas rurais (INSTITUTO UNIBANCO, 2019, p. 25). O ensino médio roraimense detinha 20.215 matrículas em um total de 128 escolas de ensino médio regular (p. 25) e 55 escolas de ensino médio indígena, sendo 32 de ensino médio indígena diferenciado, com 2.119 alunos/as, aproximadamente em 2016 (VOLTOLINI, 2018, p. 58).

No Brasil, segundo o Inep, em 2015, havia 27.415 alunos/as indígenas no ensino médio. Para Luciano (2019, p. 136), ocorreu um aumento significativo na presença desses/as estudantes no ensino médio. O crescimento, entre 2002 e 2015, foi de $2.309 \%$, saindo de um patamar de 1.187 estudantes indígenas para aquele referido em 2015. Entretanto, Luciano indica problemas característicos desse nível de ensino para o universo indígena: o fato de as escolas públicas indígenas de ensino médio estarem sob responsabilidade dos governos estaduais, o que ocasionaria a distância das comunidades e a ausência da participação dos indígenas nas decisões das escolas, inversamente ao que aconteceria no ensino fundamental I e II, majoritariamente sob responsabilidade das administrações municipais, podendo muitas vezes as populações indígenas participar dos conselhos municipais de educação e contar com grande representatividade populacional e eleitoral. Nas escolas de ensino médio indígenas, haveria poucas ações de intervenção. Menor participação e menor controle social das comunidades sobre as escolas seriam a regra (p. 136).

Luciano também aponta a baixa qualidade do ensino oferecido nas escolas de nível médio indígena, o que já constatei em trabalho de campo em Roraima. O autor chama a atenção para o momento em que esses/as jovens indígenas passam ao nível médio de ensino, que os/as direcionaria para um distanciamento de suas aldeias ou comunidades:

\footnotetext{
O que preocupa é que esta fase de ensino e de vida individual (adulta) representa um momento decisivo na vida do jovem indígena, uma vez que o encaminhará para uma determinada perspectiva individual e social. Desta forma, para o jovem indígena, essa etapa representa uma passagem da vida de aldeia (indígena, tradicional) para a vida não indígena (cidade, mão-de-obra, mercado etc.). (2019, p. 137)
}

Ele acredita que o fato de essas escolas terem pouca participação das coletividades indígenas e terem uma proposta mais voltada para os modelos urbanos "de ensino médio, disciplinar, profissionalizante para o mundo branco e centrado exclusivamente nos 
conhecimentos dos brancos" prejudica a relação construída no ensino fundamental entre esses/as estudantes e seus locais de origem.

Para as escolas indígenas diferenciadas, desde 2014, no estado de Roraima existem matrizes curriculares aprovadas pelo Conselho Estadual de Roraima no Parecer 18/2013, “que tem a finalidade de orientar e disciplinar as atividades pedagógicas, definindo os componentes curriculares, os dias letivos e a carga horária mínima das disciplinas" (VOLTOLINI, 2018, p. 60). Nesse parecer se articula a conciliação da base nacional curricular comum com uma parte diversificada que contemplaria "as disciplinas de Arte Indígena, Língua Indígena e Prática de Projetos no Ensino Fundamental e Médio e Antropologia no Ensino Médio” (p. 60).

Essas escolas apresentavam poucos recursos tecnológicos. Das 749 escolas públicas do estado de Roraima, apenas 47,8\% tinham computadores e apenas $27 \%$ dos aparelhos tinham acesso à Internet. A maioria das escolas indígenas de ensino médio pertenciam à rede estadual e, comparando-as com as escolas públicas estaduais do restante do país, 94,3\% destas possuíam computadores, sendo 88,5\% com acesso à Internet. Em Amajari, 5 das 6 escolas públicas do município tinham computadores, só 3 delas com acesso à Internet. Em Pacaraima, onde se localizam Surumu e Contão (comunidades das quais é oriunda boa parte dos/as alunos/as que entrevistei) existiam 11 escolas públicas, incluindo o Centro Indígena de Formação e Cultura Raposa Serra do Sol. Somente 2 tinham computadores e 1 tinha acesso à Internet (INSTITUTO UNIBANCO, 2019 p. 34-35).

Essa realidade acabou impossibilitando que o CAM realizasse aulas não presenciais durante o auge da pandemia de covid-19. Entre os cinco campi do IFRR, o Câmpus Amajari foi o único que não retornou as aulas não presenciais em junho de 2020, pela dificuldade que o corpo discente tinha em acessar computadores e celulares ou ter acesso à Internet.

Tabela 1 - Infraestrutura e serviços públicos das escolas com ensino médio regular - Roraima

\begin{tabular}{lc}
\hline \multicolumn{1}{c}{ INFRAESTRUTURA } & $\mathbf{( \% )}$ \\
\hline Biblioteca & 74,8 \\
Laboratório de informática & 73 \\
Banheiro ou sanitário & 91,3 \\
Banheiro adequado a alunos com deficiência & 16,5 \\
Laboratório de ciências & 15,7 \\
Quadra de esportes & 48,7
\end{tabular}


Professores

Abastecimento de água pela rede pública

Esgotamento sanitário ligado à rede pública

Lixo coletado periodicamente

Abastecimento de energia elétrica pela rede pública
74,8

47

10,4

48,7

73,9

Fonte: INSTITUTO UNIBANCO, 2019.

Esses dados caracterizam as deficiências e dificuldades que os jovens enfrentam diariamente na rede pública do estado. Luciano (2019) sugere, como formas de equacionar algumas dessas dificuldades, mais investimentos e escolas indígenas de ensino médio nas comunidades, o que evitaria as situações vivenciadas pelos/as estudantes no IFRR Câmpus Amajari, como por exemplo:

\begin{abstract}
jovens indígenas que todo dia saem de suas aldeias e enfrentam horas de viagem de ônibus em estados precários quando não de quilômetros de caminhada a pé para estudarem em escolas não indígenas mais próximas, porque não tem ensino médio em suas aldeias ou mesmo as séries finais do ensino fundamental. Nessas escolas não indígenas os estudantes indígenas enfrentam diariamente toda sorte de preconceito, discriminação e racismo, além das duras dificuldades de transporte e alimentação. Por isso é urgente a implantação de escolas com ensino médio nas aldeias e dentro das terras indígenas. (p. 138)
\end{abstract}

Um exemplo da precariedade das escolas indígenas no estado de Roraima é o que ocorre na Terra Indígena São Marcos. Existem 32 escolas criadas nessa região e credenciadas pelo governo estadual como indígenas. Destas, 18 são de ensino médio e apenas 5 têm prédios construídos. As construções são feitas de forma precária pela própria comunidade, faltam materiais didáticos e há dificuldade de contratação de professores efetivos ${ }^{46}$. Abaixo, uma foto da sala de aula, diretoria, secretaria e biblioteca improvisadas pelos moradores da comunidade Maruwai.

46 RAQUEL, Marta. Roraima: abandonados pelo governo, indígenas decidem construir sua própria escola. Brasil de Fato, 17 de outubro de 2020. Disponível em: https://www.brasildefato.com.br/2020/10/17/roraimaabandonados-pelo-governo-indigenas-decidem-construir-sua-propria-escola. Acesso em: 30 nov. 2020. 
Figura 21 - Escola Estadual Indígena José Joaquim (Comunidade Maruwai - TI São Marcos)

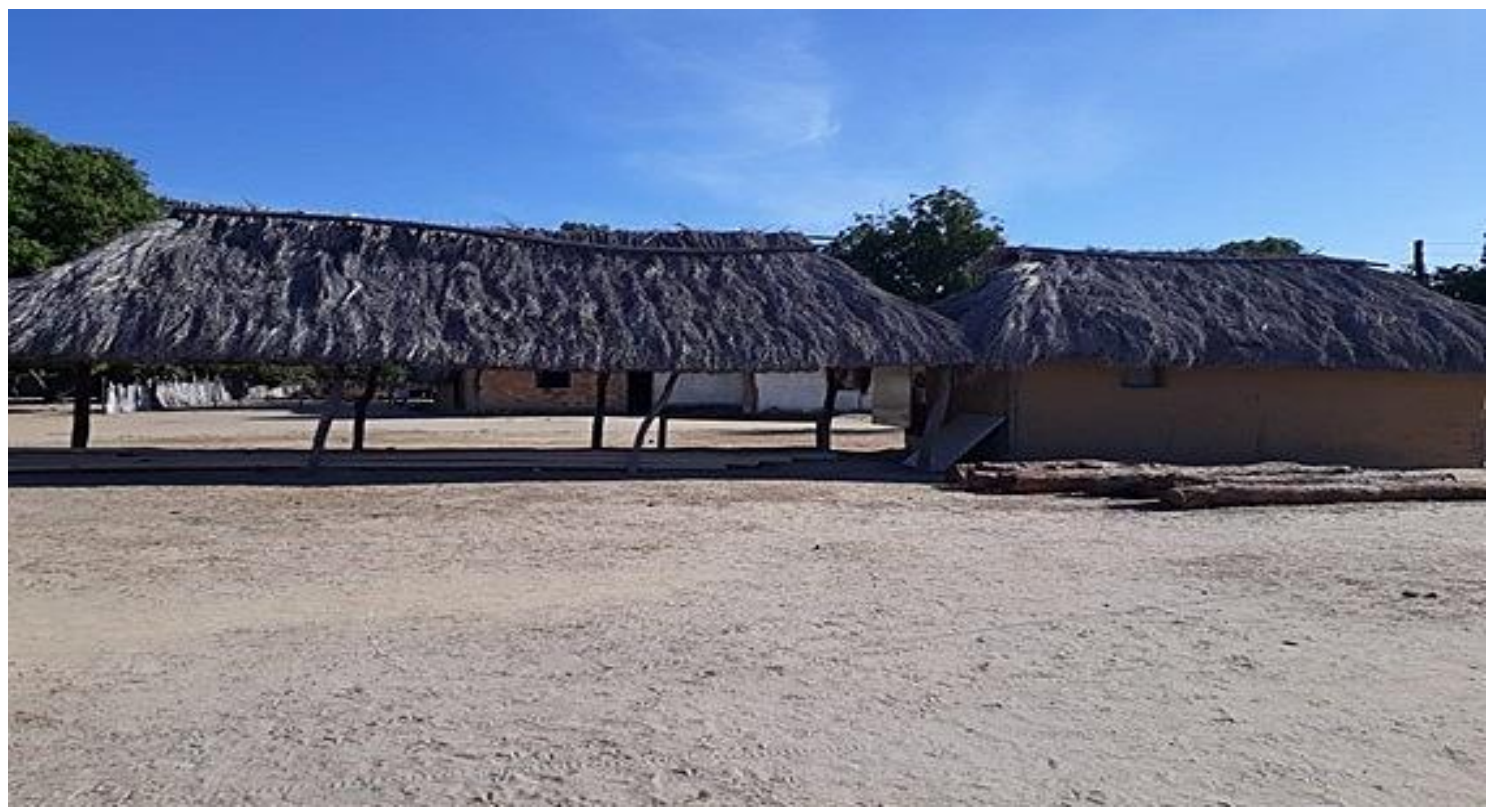

Fonte: Jefferson Ferreira.

Segundo dados do Cimi, existem 260 escolas indígenas em Roraima e 96\% delas foram construídas pelas próprias comunidades ${ }^{47}$. Essas situações, somadas às dificuldades de acesso às comunidades nos períodos de chuva e aos problemas já relatados na Tabela 1, da página 92, atestam a precariedade em que se encontram as escolas indígenas de Roraima.

Além desses problemas, também são listadas por Repetto (2006, p. 58-59) questões culturais que afetam a vida dos estudantes, tais como o conflito geracional. Enquanto os mais velhos entendem a luta por terra como fundamental para melhorar suas vidas, pois construíram suas experiências de vida envolvidos nesses conflitos, outros segmentos entendem a educação escolar como uma forma de "preparar o aluno para o mercado de trabalho no mundo dos brancos":

Alguns dos mais velhos, no meio ao debate sobre as condições dos estudantes, ressaltaram "como antes tudo era mais difícil" e compararam: a escola era longe, hoje está no centro da comunidade; antes tinham que carregar água no balde, na cabeça, hoje a água é encanada; antes tinham de trabalhar cedo na roça com o pai, hoje muitos estudantes não querem mais trabalhar na roça ("não estudo para pegar na enxada" é uma resposta recorrente segundo eles); antes não tinham sapato e aprendiam apanhando (era proibido falar em "gíria" e se apanhava de palmatória), hoje as pessoas mais idosas reclamam que é mais fácil estudar, mas acrescentam que os jovens não dão valor, não estudam direito, não trabalham o suficiente no mundo dos brancos. (p. 58) 
Em algumas entrevistas com discentes, encontrei certo incômodo em terem que manter práticas características das comunidades indígenas, como apender a língua materna, que eles/elas identificam como "chato". Em conversas com gestores das unidades educacionais das comunidades atendidas pelo CAM, eles relataram que alguns/algumas alunos/alunas, bem como pais e mães, não aceitam projetos que envolvam os discentes em atividades tradicionais como, por exemplo, aprender a manter uma roça, ou práticas de danças, pois querem que a escola ensine outras "coisas".

A presença de indígenas fora das aldeias, vivendo em contextos urbanos, tem gerado tensões, pois os jovens são os que mais desejam sair das comunidades e, aproveitando as políticas de permanência e ações afirmativas, são os que ingressam em cursos superiores. No caso dos/as estudantes do CAM, isso já acontecia no ensino médio, pois grande parte dos/as estudantes beneficiados/as pelos alojamentos da instituição eram indígenas e já vivenciavam essa experiência de estar fora das aldeias por um longo período.

Melo (2018) destaca os desafios desses/as jovens em contexto urbano, levando em consideração as dificuldades que sofrem por terem constantemente seus pertencimentos étnicos questionados, ora pelas instituições públicas, ora pelos próprios indígenas que vivem nas comunidades.

Com o advento das políticas de ações afirmativas, houve um acesso maior à Universidade Federal de Roraima e às demais Instituições de Ensino Superior (IES), a ser discutido de modo detido no tópico final deste capítulo.

As diferenças de aprendizado entre os estudantes, relatadas por professores indígenas e explicitadas por Repetto (2006, p. 59), também ocorrem no CAM: "São alunos que, embora necessariamente não apresentem problemas de aprendizagem, precisam de um acompanhamento especial. Isso deixa os professores num dilema, pelas dificuldades de se trabalhar com o desnível".

Foram criadas no câmpus "turmas de aceleração" em horários diferenciados para suprir deficiências apresentadas pelos/as alunos/as nas disciplinas de Língua Portuguesa, Matemática e Física. Entretanto, os/as alunos/as entrevistados/as falaram sobre dificuldade de adaptação ao sistema de aulas que duram o dia todo, tendo início às 7 h30 e se estendendo até às $18 \mathrm{~h}$, com intervalo para o almoço das $12 \mathrm{~h}$ às $13 \mathrm{~h} 30$. Apesar de alguns docentes considerarem que os/as estudantes têm que se dedicar mais por não trabalharem, trata-se de um cotidiano intenso e cansativo, pois são muitas disciplinas ao mesmo tempo e, em algumas situações, são abordados temas sem nenhuma conexão entre si, tampouco com as realidades desses/as educandos/as. 
Neste sentido, Junior (2017, p. 189) faz coro com os/as estudantes em sua crítica ao acúmulo de disciplinas.

\begin{abstract}
Contudo, ao analisarmos cuidadosamente o projeto de curso e vivenciar o cotidiano dos discentes do Ensino Médio Integrado, vem à luz a necessidade de se pensar um currículo proposto/formal e em ação que (re)configure a relação disciplinar tradicional, tendo em vista que uma grade curricular com 20, 21 disciplinas por ano letivo está longe de se apresentar como uma proposta inovadora e que está interessada em aprofundar o processo de formação vinculado com o saber científico e tecnológico. Resultando em restrições no desenvolvimento da pesquisa, da extensão, de projetos de ensino, da prática esportiva e cultural que o espaço escolar pode realizar.
\end{abstract}

A sobrecarga se agrava quando as variadas disciplinas dificilmente têm propostas interdisciplinares. As aulas, independentemente das disciplinas, vão se acumulando em uma sequência diária intensa e os estudantes se esforçam por acompanhá-las.

Repetto descreve, finalmente, a frustração que os/as alunos/as do ensino médio regular indígena sentem ao concluírem os estudos, dado que não conseguem empregos na cidade e muito menos nas comunidades (2006, p. 6). Isso estimularia o desejo pelo ensino profissionalizante e por um "ensino de qualidade" para terem mais condições de acesso ao ensino superior. As lideranças destacaram esse desejo como um dos principais motivos que levavam os estudantes ao CAM. O tuxaua da comunidade Três Corações ${ }^{48}$, que sedia em sua região um ensino médio diferenciado, explicou-me que o fato de a escola não ser técnica e o desejo dos estudantes por obterem uma profissão para poderem adquirir bens materiais os animavam a realizar essa tentativa de aprendizado no câmpus.

A ex-tuxaua da comunidade Guariba ${ }^{49}$ fez notar, como fator de ida dos alunos ao Instituto, a presença dos cursos técnicos. Alguns alunos já formados trabalhavam, inclusive, nos projetos de criação de peixe e de gado. Ela lamentou o fato de as comunidades não apoiarem totalmente os alunos quando eles retornam. O tuxaua da comunidade do Contão ${ }^{50}$ disse, por sua vez, que a comunidade precisava de estudantes com formação técnica para ajudar a melhorar a produção na região. Informou também haver dificuldades para conduzir projetos por falta de conhecimento técnico, usando como exemplo disso o açude com cinco tanques para a criação de peixes, atividade que não conseguiam realizar por não saberem utilizá-los.

Assim, os "benefícios" do Instituto motivam o deslocamento dos estudantes indígenas: o transporte gratuito, a alimentação, a ausência de provas escritas no processo seletivo para as vagas no ensino médio (feitas por análise curricular) e a possibilidade de estar alojado/a,

48 Entrevista ao autor, fev. 2018.

49 Entrevista ao autor, fev. 2018.

50 Entrevista ao autor, fev. 2018. 
associada aos cursos profissionalizantes ofertados pelo CAM em contraposição às opções existentes em suas comunidades no ensino médio.

Tais situações no ensino médio estadual explicam o entusiasmo pelo CAM apresentado por vários estudantes que entrevistei. Dois deles ${ }^{51}$ cursavam o último ano no Centro Indígena de Formação e Cultura Raposa Serra do Sol e se transferiram para o CAM para reiniciar o curso. Estavam no $2^{\circ}$ ano do ensino médio integrado. Foram assertivos em relação às ausências de professores e à falta de infraestrutura do Centro e descreveram sua satisfação por estarem estudando no Instituto.

Isso, mais ausência de professores. Às vezes, nós pegava dois meses de aula e faltava um mês sem professor: ficava só na manutenção dos setores, mesmo.

Bom, eu estou achando bom o curso, tem mais professores qualificados, professores de outros estados que têm um nível maior de formação. Não quer dizer [que] na comunidade também não tenha. Tem, mas ainda no processo de formação ainda, entendeu $?^{52}$

A falta de professores mencionada ocorre, em grande medida, pela ausência de concursos específicos para indígenas. Exemplificando a situação, em 2019, em meados de abril, ainda não haviam sido realizados os seletivos para contratação de professores substitutos para as escolas das comunidades, o que impossibilitava o início do ano letivo para as escolas indígenas até aquele momento.

Já em 2004, no relatório sobre as demandas do ensino médio indígena diferenciado implantado na rede estadual em 2003 (que ocasionou um aumento no número de escolas de ensino médio indígena diferenciado de 4 para 32), constatou-se um alto número de evasões depreendido da fala dos alunos oriundos de escolas indígenas. A evasão foi associada:

a) às constantes faltas de professores; b) à falta de bibliotecas e de condições para o
estudo e a pesquisa. Como já salientado, em todos os casos observados, os estudantes
de EM se veem obrigados a pesquisar nos livros do EF, devido à falta de material
adequado a seu nível de estudo; c) dificuldades no transporte, especialmente no
inverno, quando as chuvas dificultam o acesso às comunidades, o que é feito de
bicicleta ou a pé. (REPETTO, 2006, p. 43)

Na pesquisa de campo de 2019, verifiquei as dificuldades das escolas indígenas quando estive em uma audiência pública realizada pelo Ministério Público com a participação de lideranças indígenas e membros do governo estadual. Visitei também quatro unidades escolares indígenas de ensino médio consideradas diferenciadas. Nesse trabalho de campo, a falta de professores, que impossibilitava o ano letivo dessas escolas, se tornou explícita: enquanto na capital Boa Vista as aulas seguiam o calendário normal, ainda em abril as escolas indígenas não 
tinham iniciado seu ano letivo. Consequentemente, as reivindicações giravam em torno de concurso público diferenciado para professores/as indígenas, além de melhoria das condições estruturais e construção de escolas, porque em algumas regiões os estudantes estavam em unidades escolares improvisadas pela própria comunidade.

Mesmo diante de todas essas dificuldades, Repetto (2006, p. 47) elaborou um relatório sobre a implantação do ensino médio indígena diferenciado e, entre as 17 escolas indígenas em que fez trabalho de campo, encontrou quatro que classificou como "inovadoras". Não definiu exatamente o que entendia como práticas inovadoras, mas deixou entender serem práticas pedagógicas que escapam daquelas comumente utilizadas nas escolas estaduais indígenas.

$\mathrm{O}$ autor considera as escolas indígenas estaduais de ensino médio na Comunidade Manoá (Escola Estadual Indígena Nossa Senhora da Consolata), na Comunidade Tabalascada (Escola Estadual Indígena Edmilson Lima Cavalcanti), na Comunidade Truaru (Escola Estadual Indígena Rosa Nascimento) e na Comunidade Boca da Mata (Escola Estadual Indígena Tuxaua Antonio Horácio) com a presença de propostas pedagógicas “inovadoras", tendo em comum a presença de professores/as que estudavam ou tinham estudado no Instituto Insikiran, na Licenciatura Intercultural. Assim, seriam tentativas de desenvolver uma prática pedagógica diferenciada, valorizando elementos da comunidade às quais pertencem, tendo em vista um aprendizado dinâmico e mais voltado para as questões locais de cada escola, fugindo do padrão homogeneizante da maioria das instituições de ensino.

Os Macuxi são o povo indígena com maior população no ensino médio em Roraima. Dos 1.213 estudantes indígenas no ensino médio em 2005, 833 eram macuxi (REPETTO, 2006, p. 21). Isso, em grande medida, se vincula ao maior número dessa etnia no estado e também ao seu maior tempo de contato com a sociedade envolvente.

\subsection{A educação escolar indígena em Roraima}

A Constituição de 1988 reconheceu direitos aos povos originários e abriu espaço para uma educação escolar indígena diferenciada, que passou a ganhar força na legislação por meio da Lei de Diretrizes e Bases de 1996, bem como dos Parâmetros Curriculares Nacionais e do Plano Nacional de Educação. Esse momento é visto por Grupioni como um processo que teve

origem na articulação de um conjunto de atores que buscavam construir um novo papel para a escola indígena e que nos anos 90 conseguiram impactar o Estado, mudar seu perfil de atuação e impor uma nova agenda política que, sob a bandeira de reconhecer a diversidade e o direito à diferença, resultou, na década seguinte, na inserção dos índios no sistema educacional do país e na universalização da escola entre grupos indígenas. (2008, p. 51) 
O movimento indígena, as agências indigenistas e o Estado se viram diante de uma realidade, a partir da primeira década dos anos 2000, na qual houve institucionalização das propostas de educação escolar indígena diferenciada. Posteriormente, paralisou-se o desenvolvimento dessas propostas inovadoras, o que causou frustração generalizada entre os grupos envolvidos. A avaliação de Grupioni reitera:

A escola indígena, tal como ela se configura em sua diversidade Brasil afora, continua
sendo um projeto inacabado, incompleto e que requer uma atitude combativa por parte
de membros das comunidades indígenas. Tal como foi necessário um investimento
indígena em colocar suas expressões e formas culturais em pauta, cabe, talvez mais
ainda agora, antes que se enrijeçam fórmulas e procedimentos burocráticos impostos
pelo Estado Nacional e seus agentes, uma postura ativa dessas comunidades em
relação às suas escolas, de modo a poderem realizar por meio delas os projetos que
lhes interessam. (2008. p. 212)

Havia em Roraima 283 escolas indígenas ${ }^{53}$ com 14.661 alunos, das quais 36 eram de ensino médio, atendendo a 1.400 alunos, aproximadamente. Segundo o Censo IBGE de 2010, o estado contava com a maior população originária (49.637 indígenas), em números proporcionais, na Federação. De acordo com dados da Funai em 2009, uma população de etnias variadas: Ingarikó, Macuxi, Patamona, Taurepang, Waimiri-Atroari, Wapichana, Wai-Waí, Yanomami e Ye'kuana (BORTOLON, 2014, p. 16). Porém não é regra nessa região a escolarização multicultural. Déborah Freitas (2003), sobre escolas indígenas macuxi na Terra Indígena Raposa Serra do Sol, elencou apenas três multiculturais dentre as 283 existentes em todo o estado.

Marcos de Freitas (2007, p. 39) também questionou a predominância de uma escola indígena multicultural, bilíngue e diversificada no estado, afirmando acompanhar, nas assembleias de professores indígenas, relatos de "precariedade nas instalações físicas, falta de materiais didáticos adequados etc.”. Todavia, a luta por uma escola diferenciada e específica em Roraima remonta às décadas de 1970 e 1980, quando o movimento dos professores indígenas e as organizações indígenas ganharam espaço na região.

Em Roraima, há em torno de 20 organizações indígenas, já mencionadas anteriormente. Além dessas organizações, surgiram mais três específicas para os/as indígenas que residem ou circulam na capital Boa Vista, a saber: Organização dos Índios da Cidade (Odic), Associação Cultural Indígena Kapói e Associação Municipal Indígena Kuaikrî.

53 Essas escolas indígenas em sua maioria eram do governo estadual (252) ou municipais (31). Essa transferência de funções do Governo Federal para as esferas estadual e municipal, atestada pelo Decreto Presidencial n. ${ }^{\circ}$ 26/91, gerou uma série de dificuldades para o desenvolvimento das políticas de implementação da educação escolar diferenciada, pois nessas esferas locais não havia técnicos qualificados para essas ações. Além disso, os conflitos por questões territoriais dificultaram as relações entre as populações originais e os agentes estatais (GRUPIONI, 2008, p. 45). 
Segundo Melo, os objetivos da Odic são, entre outras pautas, atender demandas

oriundas das reuniões, como a capacitação de professores vinculados ao Estado para o ensino direcionado aos alunos indígenas da cidade, a valorização e o ensino das línguas indígenas nas escolas públicas municipais, o fomento à formação superior indígena, o fomento à produção e venda de artesanato, a criação de um centro cultural indígena em Boa Vista, dentre outras demandas relacionadas especialmente à educação. (p. 99)

A Associação Cultural Indígena Kapói, segundo aquela autora, busca demarcar "um espaço de identidades culturais indígenas manifestadas nas artes e culinária", pois, conforme sua fundadora, não se encontravam essas características nas demais organizações (MELO, 2018, p. 103). Já a Associação Municipal Indígena Kuaikrî surgiu no momento de conflitos gerados pela homologação da TI Raposa Serra do Sol, em 2004, e serviria como um apoio aos/às indígenas que iam para Boa Vista expulsos das fazendas, vítimas de ameaças de morte ou assustados com ataques às aldeias onde residiam, e não encontravam nenhum suporte na capital. De acordo com suas lideranças, o seu principal diferencial em relação às demais organizações seria sua atitude combativa diante da Funai e dos órgãos estatais, traço que não encontravam nas demais organizações (p. 109).

Segundo Repetto ${ }^{54}$, que confirma proposições de Santilli (2001, p. 38-47), essas organizações indígenas são vistas com olhar crítico, pois são motivo de disputas e conflitos entre as várias etnias do estado. Assim, a despeito da sua importância nas lutas dos povos indígenas de Roraima, requer-se visão cautelosa sobre sua atuação e relação com os poderes estatais locais. Santilli entende que essas organizações indigenistas e indígenas e as lideranças foram construindo relações clientelistas com os regionais e as populações indígenas e que, muitas vezes, foi a disputa pelo acesso a essas populações que deu origem a organizações.

Para Repetto (2008b), algumas organizações indígenas, no caso de Roraima multiculturais, representando mais de uma etnia ao mesmo tempo, apresentam divergências entre si. No momento da demarcação das terras indígenas Raposa Serra do Sol e São Marcos, o autor identificou quatro grupos que defendiam interesses diferentes para a causa dos povos de Roraima. Um primeiro defendia a demarcação em ilhas e o segundo, de forma contínua, enquanto outro estava preocupado com questões mais específicas de comunidades locais, chamado pelo autor de “movimentos pela produção". Um último lutava pela "educação indígena diferenciada". Esses diferentes movimentos dentro das organizações indígenas revelam a diversidade desses povos e dos interesses na região (REPETTO, 2008b, p. 156-158).

54 Entrevista ao autor em 23 de setembro de 2017 nas dependências da UFRR. O antropólogo, professor do Instituto Insikiran, relatou várias disputas envolvendo lideranças formadas naquela universidade, que acabaram afastando pessoas críticas às organizações indígenas pertencentes aos quadros da instituição. 
Contudo, não se pode negar a importância dessas organizações, que colaboraram na resistência e na sobrevivência dos povos originários do estado, auxiliando-os em suas disputas com os não indígenas. Pode-se dizer que seu protagonismo possibilitou o fortalecimento e conquista de direitos fundamentais para os povos indígenas locais. Grupioni (2008), referindose aos professores indígenas, também alude a essa relação entre as lideranças indígenas e o Estado.

Nesse percurso, o que era alternativo, porque construído à margem do Estado, foi, aos poucos, sendo reconhecido, e fornecendo matrizes a partir das quais o Estado brasileiro configurou uma nova política pública, centrada na idéia da possibilidade de valorizar as línguas e as culturas indígenas no ambiente escolar, tendo à frente dessa instituição membros das respectivas comunidades indígenas. (p. 168)

Em 1981, as lideranças macuxi conseguiram a transferência do Centro de Formação de Líderes Indígenas da capital Boa Vista para a Vila do Surumu, situada no município de Pacaraima, dentro da Terra Indígena Raposa Serra do Sol. Em 1985 ocorreu o "Dia D da Educação", um debate "que reuniu professores, lideranças, técnicos em educação e religiosos na fazenda São Marcos, espaço que é historicamente marcado como ponto de encontro dos índios da região" (FREITAS, 2003, p. 60). Desses encontros, surgiu um documento que descreveu uma série de reivindicações características da escola multicultural indígena. Em 1986, a Secretaria de Educação criou o Núcleo de Educação Indígena (NEI) para auxiliar no cumprimento dessas reivindicações.

Com a promulgação da Constituição de 1988, a luta por uma educação diferenciada foi ampliada e fortalecida. Segundo Grupioni (2008, p. 73),

Com o advento da Constituição de 1988 e dos direitos nela inscritos, os grupos indígenas no país foram, então, alçados a um novo patamar jurídico: o de serem reconhecidos como coletividades portadoras de modos de organização social próprios, que têm direito a manterem suas línguas, tradições e práticas culturais, em terras tradicionalmente ocupadas para uso permanente, onde possam reproduzir-se física e culturalmente. Ao Estado brasileiro impôs-se a determinação da proteção desses grupos e do provimento das condições necessárias à sua perpetuação. Estes têm sido apontados como os maiores saldos da Constituição de 1988.

A Constituição deu condições, até então não vivenciadas pelos povos originários, de assegurar seus modos de vida de forma estável e legalmente amparada. Essa nova situação fortaleceu as organizações e movimentos indígenas e indigenistas para ampliar suas lutas por uma escola diferenciada.

Luciano (2019, p. 38-42) enumera os benefícios que a Carta Magna trouxe aos povos indígenas. Primeiro, a superação do fantasma do seu desaparecimento, representada pelo aumento dos índices de crescimento populacional; o reconhecimento da capacidade civil dos povos indígenas, eliminando a relação de tutela estatal; “o reconhecimento do Direito à 
Diferença, que garante aos povos indígenas o direito de permanecerem como tais indefinidamente, ao reconhecer suas organizações sociais, costumes, línguas, crenças e tradições (Artigo 231)” (p. 40); a retomada da noção de direitos originários, especialmente na questão territorial; e, por fim, "assegurar aos povos indígenas a utilização de suas línguas e processos próprios de aprendizagem no ensino básico (Artigo 210, § $2^{\circ}$ ), por meio da educação escolar indígena específica e diferenciada" (p. 41). Esses avanços representaram um destacado protagonismo indígena nessas conquistas e a possibilidade de "novos tempos" para os povos indígenas (p. 42).

Em 1990, ocorreu a criação da Organização de Professores Indígenas de Roraima (Opir) e o I Encontro de Professores Indígenas do estado. A organização era similar àquela que envolvia professores do Amazonas, Acre e Roraima, e que promovia encontros desde 1988, buscando organizar a educação indígena na região Norte (SILVA, 1997). Em 1991, a Opir realizou o I Seminário Internacional de Educação Indígena de Roraima, que resultou na Carta de Roraima, documento entregue à Secretaria da Educação do estado, com as seguintes reivindicações:

- habilitação de professores indígenas em nível de $2^{\circ}$ grau;

- implantação das séries finais nas comunidades;

- participação de professores índios em comitês e conselhos regionais e nacionais;

- consulta às comunidades antes de quaisquer tomadas de decisões;

- respeito à diversidade étnica da região;

- transformação do NEI em divisão;

- ensino da língua indígena na escola;

- reformulação dos currículos escolares, adaptando-os à realidade de cada maloca;

- produção de material didático, partindo de cada realidade e aproveitando o material já existente na Diocese e Meva (Missões Evangélicas da Amazônia);

- autogerenciamento das escolas;

- escola bilíngüe e bicultural;

- incentivo à pesquisa e veiculação correta da questão indígena nas escolas não índias, procurando evitar preconceitos. (FREITAS, 2003, p. 62)

Essas lutas foram estimuladas por outras conquistas legais impostas pelos movimentos indígenas organizados. Uma destas foi a nova Lei de Diretrizes e Bases da Educação Nacional, sancionada em 1996, na qual pela primeira vez se menciona a necessidade de a educação escolar indígena nas aldeias ser bilíngue e intercultural, e se estabelece um duplo propósito para essa educação, no Artigo 78: “proporcionar aos índios, suas comunidades e povos, a recuperação de suas memórias históricas; a reafirmação de suas identidades étnicas; a valorização de suas línguas e ciências”, e garantir “o acesso às informações, conhecimentos técnicos e científicos da sociedade nacional e demais sociedades indígenas e não-indígenas” (BRASIL, 1996). 
Grupioni (2008, p. 80) também reforça a importância dos artigos da LDB como motivadores dos dispositivos legais para o desenvolvimento da educação escolar indígena diferenciada.

O caráter específico da educação a ser praticada nas aldeias contempla, pois, a
formação de pessoal especializado (a lei não restringe a índios essa formação, ainda
que seja este o sentido), o desenvolvimento de currículos próprios a cada grupo, já
que estes devem incluir "os conteúdos culturais correspondentes às respectivas
comunidades" que serão postos em prática por meio de materiais didáticos
específicos, portanto relativos a cada contexto cultural e lingüístico particular, e, por
fim, diferenciados, seja em relação aos materiais didáticos nacionais, seja em termos
dos objetivos do ensino e, ainda, dos "processos próprios de aprendizagem" de cada
grupo indígena, também assegurados na LDB pela repetição do Artigo 210 da
Constituição Federal (Artigo 32 na LDB).

Posteriormente, o Plano Nacional de Educação de 2001 concluiu a base legal para a implantação da educação escolar indígena diferenciada. A década de 1990 se notabilizou pelas condições criadas dentro do MEC para a aceitação de propostas e implantação de mudanças importantes na construção de uma educação específica para os povos originários.

Luciano (2019, p. 110) relaciona avanços para os povos indígenas nos períodos dos governos petistas, que possibilitaram um fortalecimento do processo iniciado nos anos de 1990, principalmente durante o governo Fernando Henrique Cardoso:

Foram garantidos alguns importantes fóruns de participação às lideranças e organizações indígenas, tais como as Conferências pela Igualdade Étnico-Racial, as Conferências sobre o Meio Ambiente, as Conferências de Saúde, as Conferências de Saúde Indígena, as Conferências de Educação, a I Conferência Nacional de Educação Escolar Indígena, a Conferência da Juventude e a Conferência das Mulheres. De forma mais específica vale ressaltar como importantes conquistas a homologação da terra indígena Raposa Serra do Sol, a Ratificação da Convenção 169/OIT, a criação da Secretaria Especial de Saúde Indígena (Sesai), a criação do Programa Nacional de Gestão Ambiental das Terras Indígenas (PNGATI), os Programas de Acesso e Permanência ao ensino superior que também beneficiaram os estudantes indígenas (tais como o Programa Universidade Para Todos (Prouni), a Lei das Cotas e a Bolsa Permanência) e os programas de formação de professores indígenas (Licenciaturas Interculturais/Prolind, Magistério Indígena e Saberes Indígenas na Escola).

No entanto, o autor expõe problemas para levar adiante tais conquistas, problemas que ainda não foram solucionados. Continua exortando à total atenção principalmente a questões fundiárias e ao imperativo de desvincular da Funai o diálogo com os povos indígenas, redirecionando-o às organizações de representação dos próprios indígenas. Ao fazer um balanço do que não funcionou num período de 14 anos (2002-2016) em relação à educação indígena, o autor menciona

as dificuldades de articulação da sonhada gestão compartilhada dos três níveis de ensino ou Regime de Colaboração (União, Estados e Municípios), a irracionalidade dos instrumentos e processos burocrático-administrativos inaplicáveis às regiões e terras indígenas que inviabilizam processos de construções de escolas, compra e distribuição da alimentação escolar, material escolar e didático e desenvolvimento dos cursos de formação de professores e da incongruência entre os sistemas próprios de educação indígena e o sistema nacional de educação escolar. (2019, p. 116) 
Assim, mesmo havendo garantias legais, o que se constata na maioria dos estados brasileiros é a dificuldade de implantação de inovações educacionais. Roraima não foge à regra. Para Silva (1997) e Marcos de Freitas (2005), por exemplo, os encontros e os movimentos dos professores indígenas de Roraima conduziram a um aprimoramento da educação indígena para uma escolarização específica e diferenciada e possibilitaram um avanço do processo nas comunidades.

Os próprios indígenas apresentam dificuldades de entender o conceito de escola diferenciada. Entre 2003 e 2004, foi desenvolvido pelo governo estadual o Projeto de Ensino Médio Regular Diferenciado Indígena, que partiu de 4 escolas de ensino médio regular, instituiu 26 escolas indígenas em ensino médio consideradas diferenciadas e ainda 2 escolas com ensino médio em Educação de Jovens e Adultos (REPETTO, 2007, p. 10). A implementação desse projeto foi feita sem a devida preparação dos professores e membros das comunidades, gerando confusão entre os envolvidos.

\begin{abstract}
Chegaram também novas propostas para as escolas, como a realização de oficinas ou projetos especiais, a realização de pesquisas de campo e outras atividades. Estas ações às vezes provocaram incompreensões ou resistências nas próprias comunidades, por exemplo, quando os pais achavam ruim que o professor tirasse os alunos de sala de aula para visitar a comunidade. Estas mudanças no contexto educacional vêm sendo discutidas nas reuniões e assembléias, de forma que cada vez mais as comunidades aprofundam sua compreensão do processo. (p. 11)
\end{abstract}

Repetto abordou as demandas de duas comunidades (Barata e Pium) que contavam com ensino médio, localizadas nas regiões do Taiano, município de Alto Alegre, com presença dos Wapichana e Macuxi (2007, p. 45). Ele ressaltou expectativas de estudantes e comunidades de "que o ensino médio ofereça conhecimentos significativos para a sobrevivência dos jovens e das famílias, ou seja, um conhecimento que seja capaz de melhorar a vida das pessoas". O autor também detectou um "consenso" na região, segundo o qual a escola deveria promover a profissionalização, preparar as pessoas para desenvolverem atividades "úteis", acrescentando que os estudantes se incomodavam de terem de estudar tanto e depois não conseguirem trabalho nas comunidades ou em Boa Vista.

É possível sugerir uma imagem da escolarização como uma necessidade para a sobrevivência econômica e sustentável das comunidades, devido à proximidade com a sociedade envolvente. Porém o tipo de escolarização ainda parece algo a ser construído por essas comunidades, seja porque não compreenderam nitidamente o significado de um ensino diferenciado, seja porque preferem o ensino não índio.

Essa dificuldade de entendimento da proposta de educação escolar indígena diferenciada estaria vinculada, de acordo com Grupioni, a ações burocratizantes do Estado que, 
aos poucos, foram minando os esforços para a implementação da educação diferenciada nas comunidades indígenas:

Hoje, poucas são as comunidades que controlam efetivamente suas escolas e seus professores de modo que se constata, cada vez mais, que a educação indígena diferenciada tem sido conduzida mais pelos professores indígenas, do que propriamente pelas comunidades indígenas, como se veicula nos documentos oficiais. Outro constrangimento diz respeito ao baixo investimento financeiro por parte do Estado brasileiro para levar adiante essa nova proposta de educação indígena. Hoje, os recursos disponíveis, para financiamento da educação escolar indígena, quer no âmbito federal, quer estadual, são modestos, descontínuos, pontuais e, de modo geral, insuficientes. Isso sem contar a total falta de equipamentos e recursos didáticopedagógicos em que se encontram a quase totalidade das escolas indígenas do país que, por possuírem, normalmente, um número reduzido de alunos, não são beneficiadas pelos programas nacionais de melhoria das condições de ensino. Juntese à falta de recursos financeiros a também inexistência de recursos humanos qualificados e estáveis na administração dos sistemas de ensino, com alto grau de rotatividade e pouca especialização e conhecimento técnico, o descompasso entre o que está preconizado nos referenciais desta política pública e as práticas que ela engendra são ainda mais visíveis. De modo que é possível afirmar que esse modelo de escola indígena, que se tornou hegemônico, ainda não se realizou em plenitude, fazendo com que a busca por maior escolarização por parte de indivíduos e de famílias indígenas se torne a porta de saída de suas comunidades em direção aos núcleos urbanos. (2008, p. 61-62)

Entretanto, as práticas de escolarização nas comunidades indígenas de origem dos/as estudantes mantêm acesos elementos das culturas originárias, como a língua, algumas danças e o orgulho da sua identidade. Em vários relatos dos/as alunos/as, aparece o aprendizado de elementos culturais indígenas vivenciados somente nas escolas indígenas, esquecidos ou perdidos pelas famílias, que, em muitos casos, são mistas, com casais de indígenas e não indígenas, ou de etnias diferentes. Para todos/as os/as que entrevistei, a passagem pelas escolas indígenas foi a base anterior ao ensino médio, conforme o comentário de um aluno:

Bom, eu estudei em uma escola indígena, lá na comunidade mesmo, no fundamental, e também cursei dois anos de ensino médio em uma escola de formação indígena... no Surumu (...) É diferenciada, que é só pra indígena. ${ }^{55}$

Isso somente foi possível devido ao esforço das comunidades indígenas em avançar com seus projetos de escolarização diferenciada e bilíngue. Ainda que tais projetos não estejam totalmente efetivados, as escolas com professores/as indígenas e ensino de língua são quase totalidade no ensino fundamental nas comunidades, tornando as escolas indígenas nas comunidades instrumentos de resistência da cultura originária desses povos que vivem em Roraima.

Nesse sentido, gradualmente, os indígenas foram assumindo a direção e a gestão da educação indígena. Na última década, as ações voltadas para as escolas indígenas vêm 
sendo coordenadas por eles, e isso tem resultado em grande expansão da rede escolar nas comunidades. Iniciando com as crianças menores, a rede hoje envolve não apenas jovens e adolescentes, mas também os adultos, através de várias modalidades de alfabetização e da Educação de Jovens e Adultos (EJA) que é significativa nas escolas indígenas em Roraima. (REPETTO, 2006, p. 12)

\subsection{Ensino superior para indígenas em Roraima}

A presença de estudantes indígenas em Instituições de Ensino Superior (IES) tem sido cada vez mais frequente e significativa. Estima-se que 49.026 estudantes indígenas frequentem as universidades públicas e privadas brasileiras, segundo o Censo de Educação Superior do MEC de $2017^{56}$. Os/as jovens macuxi que frequentavam o CAM também relataram seus desejos de ingressarem no ensino superior. Alguns egressos/as já realizavam esse objetivo em IES públicas ou privadas, tanto no ensino regular ${ }^{57}$ quanto no específico, como é o caso da Licenciatura Intercultural. Este curso é voltado à formação de professores/as indígenas para atuarem em escolas indígenas e foi criado em 2001 na UFRR, no Instituto Insikiran, que também oferece o curso de Gestão Territorial Indígena, criado em 2009, e o de Gestão em Saúde Coletiva Indígena (bacharelado), criado em 2012, todos com vestibular específico (SILVA LIMA, 2017, p. 165).

Além dessas opções em Boa Vista, o Instituto Federal de Roraima oferece, em seu câmpus na capital, cursos de graduação com enfoque tecnológico: Tecnologia em Gestão Hospitalar, Tecnólogo em Análise e Desenvolvimento de Sistemas, Tecnologia em Saneamento Ambiental e Tecnologia em Gestão de Turismo. Também cursos de Licenciatura: Licenciatura em Ciências Biológicas Presencial e a Distância, Licenciatura em Letras-Espanhol e Literatura Hispânica Presencial e a Distância, Licenciatura em Matemática Presencial e a Distância, Licenciatura Plena em Educação Física.

Entre cursos de pós-graduação, são oferecidos: Mestrado em Educação (IFRR/UERR), Planejamento e Gestão de Empreendimentos e Destinos Turísticos Sustentáveis, Educação: Métodos e Técnicas de Ensino a Distância, Docência da Língua Espanhola a Distância, Docência em Educação Física Escolar (UAB).

No interior, existe o curso de Agronomia no câmpus Novo Paraíso, no sul do estado, e o curso de Aquicultura no CAM. No Câmpus Amajari, em 2019, as três turmas do curso

56 Disponível em: https://www.ecoamazonia.org.br/2018/03/estudantes-indigenas-ganham-universidades/. Acesso em: 23 set. 2019.

57 Utilizo a expressão “ensino regular” no ensino superior para me referir a cursos não específicos para indígenas. 
superior em Aquicultura somavam 67 alunos/as, sendo 16 estudantes egressos/as dos cursos de nível médio do CAM. Outra opção de ensino público superior é a Universidade Estadual de Roraima (UERR). No âmbito privado, existem a Faculdade Roraimense de Ensino Superior (Fares), a Faculdade Estácio Atual e a Faculdade Cathedral. Esta última é a maior e mais reconhecida instituição privada de ensino superior em Boa Vista. Firmou um convênio com organizações indígenas (Opir, CIR, Omir e Apirr) desde 2002, e garante a cada uma o ingresso de um estudante por ano, com bolsa integral e isenção de taxa de inscrição no vestibular. Os candidatos indicados pelas organizações, porém, devem participar do mesmo processo de seleção que os demais (LISBOA, 2017a). A Faculdade de Ciências, Educação e Teologia do Norte do Brasil (Faceten) e o Grupo de Ensino Claretiano também mantêm convênio com o CIR, pelo qual fornecem bolsas de estudo no ensino a distância (EaD).

Dal Bó (2018) sugere alguns motivos que têm impulsionado os/as jovens indígenas a buscarem o ensino superior. Para ela, o aumento do número de escolas indígenas nas comunidades levou a uma necessidade maior de profissionais de educação indígena para trabalharem nessas instituições. Impulsionados/as pela exigência da formação superior para atuarem nas instituições escolares, os/as futuros professores/as indígenas das escolas básicas começaram buscando sua formação nos cursos de Licenciatura Intercultural, que tiveram seu desenvolvimento e fortalecimento no início dos anos 2000, ou em cursos regulares de Pedagogia. Entrando no universo acadêmico, esses/as estudantes foram motivados/as a continuarem seus estudos para ocuparem cargos de gestão, ou em outras áreas de interesses acadêmicos, que podiam ou não atender às necessidades das suas comunidades de origem (DAL BÓ, 2018, p. 46).

De acordo com Gersem Luciano, da etnia baniwa, o acesso dos povos indígenas ao ensino superior, além de ser um direito garantido pela Constituição, deve considerar o fato de os indígenas ocuparem $13 \%$ do território nacional (e, na região amazônica, essa área chega a 23\%), sendo importante a qualificação de líderes e moradores de Terras Indígenas para sustentarem condições mais adequadas de uso. $\mathrm{O}$ autor, além disso, pondera a respeito da importância dos povos originários com relação a seus conhecimentos, contribuições culturais e sociais que podem acrescentar frequentando as universidades. Luciano questiona ainda a formatação do acesso e do ensino oferecido aos povos indígenas nessas instituições. Ele também considera que esse ensino deveria, assim como na educação básica, ser diferenciado e diversificado, mas assinala a complexidade que essa prática exigiria no ensino superior. Descreve, então, esse embate nas maneiras de ser e propor a educação superior entre indígenas e não indígenas, nos seguintes termos: 
Estes povos desejam formação superior em seus termos, ou seja, para atender a suas demandas, realidades, projetos e filosofias de vida. Aqui reside o maior desafio da formação superior de indígenas nos contextos atuais das universidades, fundamentadas na organização, produção e reprodução de saber único, exclusivo, individualista e a serviço do mercado. O desafio é como esta instituição superior formadora pode possibilitar a coexistência lado a lado e a circulação, interação, aplicação e reconhecimento mútuo entre distintos saberes, pautados em distintas bases e lógicas cosmológicas, filosóficas e epistemológicas. Os povos indígenas, por exemplo, não gostariam de ser enquadrados pelas lógicas academicistas que alimentam e sustentam os processos de reprodução do capitalismo individualista, que têm gerado uma sociedade cada vez mais em retorno à civilização da barbárie e da selvageria, por meio da violência, da exploração econômica desumana, do império da lei do mais rico e dos que têm poder político à base de democracias das elites econômicas e políticas racistas, excludentes e injustas. (2019, p. 67)

O entendimento da necessidade de tornar o ensino superior mais próximo aos povos indígenas, assim como da importância da convivência e dos ganhos tanto para os povos indígenas quanto para os não indígenas, principalmente nos cursos regulares, perpassa o discurso de Luciano e o de Dal Bó. Entretanto, surge entre ambos uma discordância que envolve o acesso dos/as jovens e suas vivências no espaço acadêmico. Essa aparenta ser uma discussão presente tanto entre jovens do Câmpus Amajari quanto entre estudantes indígenas do ensino superior que vivem ou estudam em Boa Vista.

Dal Bó (2018, p. 49-51) notou um incômodo dos/as estudantes indígenas que passavam pelo processo de seleção para o vestibular da Universidade Federal de São Carlos (UFSCar) e, posteriormente, em suas vivências no câmpus da instituição, quando questionados/as, por docentes nas entrevistas de seleção e por colegas de curso no decorrer de suas vidas acadêmicas, sobre o motivo que os/as trazia à universidade. Dal Bó interpretou as respostas que os/as indígenas precisavam dar como estando vinculadas à comprovação de sua indigeneidade. $\mathrm{Ou}$ seja, para não indígenas estudantes ou docentes, a presença daqueles/as indígenas se justificaria mais facilmente se houvesse uma ligação com demandas coletivas de suas comunidades, que seriam mais bem-aceitas do que aquelas baseadas em motivações pessoais ou em escolhas individuais.

Para a antropóloga, os/as estudantes indígenas têm desejos e vontades próprios, e a noção de pertencimento étnico e de coletividade não poderia ser determinada ou avaliada $a$ priori por agentes externos e pelas próprias comunidades indígenas de modo desconectado das experiências desses/as estudantes. Ela não despreza a Convenção 169 da Organização Mundial do Trabalho (OIT), da qual o Brasil é signatário desde 2002 e pela qual os povos indígenas devem ser reconhecidos enquanto povos, coletividades cultural e historicamente diferenciadas dentro do Estado brasileiro. Contudo, entende que esse direito deva ser respeitado levando em consideração que o conceito de coletividade dentro do qual os povos indígenas brasileiros 
devem ser reconhecidos não poderia passar a ideia de entidades totais, pré-fixadas, anteriores às experiências e relações construídas entre as pessoas, sendo o conceito de coletivo muito fluído, podendo ter sentidos variados e circunstanciais para as próprias comunidades indígenas. Sendo assim, não vê dificuldade em que esses/as estudantes optem pelos cursos que desejam levando em conta seus anseios e projetos de futuro (DAL BÓ, 2018, p. 51).

Todavia, Luciano (2019, p. 68-69) questiona a "individualização" do acesso às universidades brasileiras, pois acredita ser um risco e uma ameaça para os "princípios e modos próprios de vida coletiva indígena". Para ele,

Do ponto de vista dos direitos coletivos dos povos originários, as vagas reservadas pelas IES não são dos indivíduos, mas das coletividades (comunidades e povos). Neste caso, são essas coletividades as responsáveis pelas escolhas dos seus candidatos e dos cursos de seus interesses, assim como pelo acompanhamento de todo o processo de formação e sua reinserção à comunidade.

Luciano reconhece os direitos subjetivos dos indivíduos indígenas, mas lamenta o fato das vagas serem ocupadas por indígenas como "indivíduos que muitas vezes não têm nenhum ou pouco compromisso com a comunidade. É uma das razões que geram as dificuldades para se manter a luta coletiva" $\left(2019\right.$, p. 69). Ele considera o direito à autodeclaração ${ }^{58}$ como o ápice da individualização por negar totalmente a autonomia coletiva dos povos indígenas. Admite, então, a importância de esse direito ser associado a outros instrumentos de declaração ou identificação étnica, como por exemplo, o de pertencimento étnico territorial, ainda que como memória histórica e linguística, e o reconhecimento de seu povo de pertencimento.

O exemplo que apresenta é o da Universidade Federal de Pernambuco (UFPE), que, em seu Programa de Pós-Graduação em Antropologia, estabeleceu um convênio com a Federação das Organizações Indígenas do Rio Negro (Foirn) para que selecionassem os candidatos que iriam realizar o curso, de modo que $100 \%$ dos candidatos vieram de suas aldeias por indicação coletiva de suas comunidades e organizações e "continuaram seus trabalhos junto às suas aldeias durante e depois da sua formação" (2019, p. 172). Luciano sublinha um benefício para os indígenas em contextos urbanos ao disputarem as vagas, pois falam português e, generalizando, "apresentam menos envolvimento com as comunidades aldeadas, pois, influenciados pelas lógicas de relacionamento nas cidades (mercado consumista e acumulativo,

58 Desde 2002, após pressão do movimento indígena, o Brasil é signatário da Convenção 169 da Organização Internacional do Trabalho sobre Povos Indígenas e Tribais em Estados Independentes. No Artigo $1^{\circ}$ fica estabelecido o critério da autoidentificação como parâmetro de garantia de direitos fundamentais. Ou seja, o mesmo documento que sustenta a noção de coletividade aos povos originários também apresenta o direito da autodeclaração, que é motivo de crítica de Luciano. 
profissão individual, concorrências e disputas políticas), tendem a ser menos sensíveis ao valor e princípio comunitário de vida".

Muitos indígenas que residem ou circulam em contextos urbanos, diz Melo (2018), vivem em comunidades próximas à capital ou mesmo residem em Boa Vista e, por diversos fatores, sofrem para conseguir o Registro Administrativo de Nascimento Indígena (Rani) ${ }^{59}$ por órgãos oficiais. São vítimas de racismo e preconceito de autoridades por viverem em cidades e não em aldeias.

\begin{abstract}
No caso dos indígenas residentes em Boa Vista, porém, não ter o pertencimento étnico reconhecido pelo Estado sob a justificativa do desaldeamento é um posicionamento que não se mostra coerente para as lideranças indígenas com as quais dialogo neste trabalho. Elas argumentam que as fronteiras territoriais estabelecidas pelo Estado não correspondem às delimitações territoriais das populações indígenas e que a cidade de Boa Vista, outrora uma grande maloca, foi construída em territórios tradicionais por onde circulavam seus ancestrais. Portanto, sua presença na cidade seria uma continuidade desse modo de habitar o território, agora ocupado por migrantes de vários lugares do Brasil (...). Nesse sentido, recusam a condição de desaldeados com a qual são concebidos pelos representantes do Estado e consideram que esta é uma forma de negar o acesso às políticas afirmativas. (2018, p. 11)
\end{abstract}

Essa negação de políticas afirmativas acontece porque o Rani é considerado uma prova de que o candidato pertence a algum grupo étnico, e não tê-lo impede, por exemplo, o acesso ao sistema de cotas reservadas aos povos indígenas de algumas universidade de Boa Vista, bem como ao curso superior de Aquicultura do Câmpus Amajari. Esse documento é objeto de diversas contendas interinstitucionais listadas e descritas por Melo (2018, p. 112-117). As dificuldades encontradas por alguns indígenas residentes em contexto urbano para retirar o documento demonstram, segundo aquela autora, a ineficácia do Rani, tanto para reconhecimento de pertencimento étnico quanto para registro ou controle interno da Funai.

O documento criado pelo Estado deveria ter a função de facilitar o acesso a programas sociais do governo. Porém a incompreensão das realidades que os povos indígenas foram obrigados a vivenciar - por não disporem de escolas de educação básica suficientes, e universidades, em suas comunidades, ou por desejarem viver em contexto urbano - os/as impede de usufruir desses programas.

De acordo com a Convenção 169 da OIT, o requerente do documento deve contar com a anuência dos seus pares étnicos para obtê-lo. Entretanto, na cidade de Boa Vista os indígenas não estão agrupados em aldeias ou por recortes de grupos étnicos, mas em organizações que

59 O Rani é um documento expedido pela Funai mediante a solicitação do/a interessado/a. Entretanto, para obtêlo é necessária a concordância das lideranças das comunidades, especificamente o/a tuxaua. 
reúnem membros de etnias diferentes, que se aproximam por vivenciarem uma situação comum diante da sociedade não indígena. Sendo assim,

A partir do momento em que agentes do Estado negam a emissão de documentos a
estes sujeitos por meio de critérios que não se adaptam às diversas realidades, não
estão apenas negando a participação destes em programas sociais, mas também sendo
deliberadamente omissos às novas dinâmicas de organização e luta do movimento
indígena. (MELO, 2018, p. 116)

No CAM, a maioria dos/as estudantes indígenas vivenciam a mesma polêmica. Observei nas conversas com lideranças, gestores e pais/mães o desejo do regresso desses/as jovens às suas comunidades, ainda que a maioria manifestasse interesse em continuar seus estudos nas universidades do estado, aumentando seu afastamento das terras indígenas.

Também no câmpus se associam o pertencimento étnico e a presença dos/as jovens em suas comunidades. Uma vinculação da função dos cursos à garantia de que os/as alunos/as possam retornar às suas comunidades parece invisibilizar o interesse desses/as estudantes em cursar outras áreas, que atendam a interesses pessoais e não a interesses supostos como da coletividade.

Toda essa complexidade se acirra quando a entrada desses/as estudantes é realizada pelas ações afirmativas, por sua vez interpretadas a partir de diversas concepções. Contudo, assim como no ensino médio do CAM, tais políticas são muito importantes para o ingresso e a permanência desses/as estudantes indígenas nos cursos superiores disponíveis nas IES do estado de Roraima.

Dal Bó (2018, p. 52-57) discute as principais definições que envolvem as ações afirmativas referentes aos povos indígenas e expõe algumas das questões. Dois grupos de pesquisas são destacados quando o assunto são os dados e reflexões sobre o tema: o Geema (Grupo de Estudos Multidisciplinar da Ação Afirmativa), criado em 2008 no IESP-UERJ, e o Instituto de Inclusão no Ensino Superior e na Pesquisa (INCTI), consolidado em 2009 na UnB (2018, p. 52). O primeiro traz influência do modelo utilizado pela Índia, tendo como referencial o objetivo de combater discriminações étnicas, raciais, religiosas, de gênero e de castas, aumentando a participação das minorias no processo político, bens materiais, redes de proteção social e no reconhecimento cultural. O outro, mesmo reconhecendo uma influência indiana, é diretamente sugestionado pelo modelo estadunidense, que relaciona e identifica os conceitos de inclusão, cotas e ações afirmativas, entendidas comumente como as políticas de $\operatorname{cotas}^{60}$ nas universidades públicas brasileiras.

60 A Lei $\mathrm{n}^{\circ} 12.711 / 2012$ garante a reserva de $50 \%$ das matrículas por curso e turno nas 59 universidades federais e 38 Institutos Federais de Educação, Ciência e Tecnologia do país a alunos oriundos integralmente do ensino 
Essa autora estabelece, assim como Luciano (2019) um vínculo com as conquistas das ações afirmativas com o aspecto racial e vê no movimento negro um grande protagonista dessas lutas pela implantação das políticas afirmativas, que tem o ápice dos debates em 2003 com a criação da Secretaria de Políticas de Promoção e Igualdade Racial (Seppir).

Segundo Dal Bó (2018, p. 55), trata-se de buscar a igualdade de acesso a um direito que tem sido desigualmente alcançado por diferentes segmentos da população brasileira, sobretudo a população negra. Ou seja, reconhecer as diferenças, a partir da perspectiva da assim chamada discriminação positiva. Nesse sentido, a questão se concentraria no conceito de identidade defendida pelas políticas de ações afirmativas que, nos exemplos da Universidade de Brasília e da Universidade Estadual do Rio de Janeiro, pautam-se pela concepção multicultural, estabelecendo o conceito de diferença como sinônimo de identidade.

Assim, para a autora, as identidades já estariam preestabelecidas pelo Estado brasileiro, a partir de critérios e conteúdos estabelecidos institucionalmente nas políticas de ação afirmativa (p. 56). Isso coloca mais um problema para os povos indígenas, devido ao fato de diferenças e identidades estarem "em um processo em aberto, de relações produzidas em contexto". Ou seja, não seriam conteúdos culturais pré-fixados que determinariam a diversidade indígena, mas processos incessantes das próprias diferenças.

Dialogando com Homi Bhabha ${ }^{61}$ e Lévi-Strauss ${ }^{62}$, ela vê nesse entendimento de multiculturalismo uma forma de colocar os povos indígenas como coletividades fechadas em si mesmas, o que levaria a uma produção de estereótipos e generalizações sobre os povos indígenas que antecederiam as relações construídas entres esses povos e os seus sujeitos. Ela utiliza o exemplo de uma aluna terena que, postulante a uma vaga do curso de Filosofia da UFSCar, era questionada, no processo de seleção, sobre uma identidade, de forma generalizada, do povo terena representada em uma dança. Acreditava-se que individualmente ela deveria ter conhecimento sobre essa particularidade, independentemente de seu contexto cultural ou vivência em sua etnia. Assim, Dal Bó conclui, no que concerne às políticas de ações afirmativas no Brasil:

ao invés de serem chamadas de diferencialistas, deveriam ser intituladas como identitárias. Isso porque, conforme vimos, a perspectiva multicultural em que elas se fundamentam estabelece uma diversidade cultural que somente permite a produção de

médio público em cursos regulares ou da educação de jovens e adultos. Os demais $50 \%$ das vagas permanecem para ampla concorrência. Disponível em: http://portal.mec.gov.br/cotas/perguntas-frequentes.html. Acesso em: 28 set. 2019.

61 BHABHA, Homi K. O local da cultura. Belo Horizonte: Editora UFMG, 1998. 441 p.

62 LÉVI-STRAUSS, Claude. Raça e história. Lisboa: Editorial Presença, 2010 [1954]. 
identidades (culturais, étnicas, raciais) recortadas, controladas, estabilizadas. O que é absolutamente distinto da produção de diferenças nos modos de ser e existir indígenas, que potencializam as relações por meio da alteridade, a partir do movimento incessante da significação. (2018, p. 62)

Ou seja, quando um indígena em contexto urbano em Boa Vista procura ter acesso a um documento, na Funai ou em outro órgão autorizado a emiti-lo, e lhe é negado esse benefício, isso demonstra o quanto se espera que esses indígenas estejam enquadrados em um modelo de identidade, construído pelos não índios, que não se relaciona com a complexidade atual desses povos.

Luciano (2019, p. 170-198) discute a importância das políticas afirmativas para as populações indígenas, em especial a Lei de Cotas. No entanto, tem algumas reservas quanto às características da referida lei, que individualizaria direitos coletivos dos povos indígenas e não consideraria a sua diversidade cultural, linguística, política, social e étnica. Assim sendo, ele defende uma cidadania diferenciada para povos diferenciados.

A principal crítica para esse autor, assim como para Dal Bó, em relação à questão das cotas, diz respeito ao acesso dos povos indígenas caracterizado em uma concepção homogeneizadora, que não considera a diversidade do processo formativo dos/as estudantes indígenas, diferente, em muitos casos, dos demais atores sociais participantes das políticas de ação afirmativa. A questão prática se daria da seguinte maneira:

Portanto, colocar os índios para disputar as mesmas vagas com pretos e pardos deixaos mais uma vez em uma situação de grande desvantagem, não por incapacidade cognitiva ou intelectual, mas por seus processos educativos distintos. A marca principal dos direitos indígenas é a diferença e a equivalência e não a igualdade ou similaridade, razão pela qual os povos indígenas têm reivindicado tratamento diferenciado em que o foco da política seja a valorização e o reconhecimento das diferenças e da diversidade e não a inclusão e homogeneização das políticas, mesmo no âmbito das políticas para a diversidade ou minorias sociais. (LUCIANO, 2019, p. 176)

Ainda assim, o autor reitera a necessidade de os povos indígenas não abrirem mão desses direitos. Sugere melhorias para o acesso desses/as estudantes, como a criação de programas de tutoria, que acompanhem os/as estudantes indígenas aprovados no sistema de cotas desde "o acesso, a permanência nas universidades até o regresso para as suas respectivas comunidades”. Luciano indica também dificuldades causadas pela adaptação ao universo acadêmico, que se distingue da escola diferenciada, diversificada e bilíngue de que alguns/as estudantes se originam. Seria necessário "nivelamento de conhecimento" e apoio para suportarem esse período de adaptação, distantes de suas famílias, culturas e modos de vida. Uma última proposta do autor é a concessão de bolsas de pesquisa que mantenham alunos/as indígenas em constante ligação com suas comunidades durante os estudos (p. 176). 
As situações de inadaptação e dificuldades de integração às realidades de ensino não indígena também são comuns no Câmpus Amajari. Apesar de a maioria dos Macuxi terem o português como língua principal e suas escolas terem características muito próximas das escolas não indígenas, em muitos relatos, nas conversas com os/as estudantes, são descritos os frequentes conflitos para se adaptarem à vida acadêmica em regime integral, longe de suas famílias e, muitas vezes, submetidos/as a situações de tensões raciais com servidores/as ou outros/as estudantes não indígenas (OLIVEIRA; LIMA, 2019).

O CAM também recebeu quatro indígenas da etnia ingarikó, em 2015, e dois da etnia Ye'kuana, em 2019, que não dominavam o português e tiveram muitas dificuldades de adaptação. A despeito dos projetos de "nivelamento de conhecimentos", ações do Caes e valorização das culturas indígenas no câmpus, as dificuldades e tensões ainda se mantiveram.

\subsubsection{A Universidade Federal de Roraima}

O principal destino dos/das estudantes indígenas em Roraima que continuam os estudos é a UFRR. Os três cursos específicos para estudantes indígenas costumam atraí-los. Esses cursos, construídos em parcerias com as organizações indígenas, principalmente o CIR, tentam possibilitar o empoderamento dos/das indígenas em suas comunidades específicas. Abrangem as áreas de Educação, Gestão Territorial e Saúde. No edital n. ${ }^{\circ}$ 051/2019-CPV ${ }^{63}$, para as vagas do primeiro e segundo semestre de 2020, que caracterizou o Processo Seletivo destinado para o Ingresso de Indígenas (PSI), foram reservadas 210 vagas no total, envolvendo 17 cursos superiores regulares e os três específicos, havendo no de Licenciatura Intercultural o maior contingente de vagas, somando este 60 e os demais, 40 vagas cada um.

Os cursos superiores específicos e os regulares requerem o mesmo tipo de exame vestibular. De acordo com aquele edital, há uma fase eliminatória contendo provas objetivas com questões relativas ao universo indígena, relacionadas aos temas: Territorialidade e questões ambientais; Sustentabilidade e povos indígenas; Educação indígena intercultural, diferenciada, bilíngue; Direitos indígenas, com base na Constituição de 1988; Medicina tradicional indígena; Doenças frequentes na comunidade; Falta de saneamento, lixo. Há também uma prova de redação. Os/as estudantes que se candidatam ao curso de Licenciatura Intercultural podem fazêla na sua língua materna. Na sua segunda fase, classificatória, ocorre a análise de currículo, na

63 Disponível em: http://ufrr.br/cpv/index.php?option=com_phocadownload\&view=category\&id=40\& Itemid=301. Acesso em: 4 out. 2019. 
qual os/as candidatos/as indígenas com maior relação com a comunidade terão mais possibilidade de acesso.

Lisboa (2017a, p. 136-138) fez um levantamento no segundo semestre de 2015 e constatou a presença de 957 indígenas frequentando os cursos de graduação da UFRR, que abarcam um total de 7.662 alunos e alunas. Do total de indígenas, 635 eram estudantes do Instituto Insikiran, divididos/as entre os cursos de Gestão Territorial Indígena e Gestão em Saúde Coletiva Indígena (somando 274 matrículas) e o curso de Licenciatura Intercultural (361 estudantes). Essa maioria no curso de Licenciatura Intercultural se deve à sua anterioridade no instituto e ao seu maior número de vagas.

Em Roraima, e em especial no Instituto Insikiran, onde se desenvolvem os cursos superiores específicos para estudantes indígenas, a presença das entidades indígenas é muito intensa, exercendo influência na organização e nas intenções desses cursos e do instituto.

O mesmo Lisboa (p. 133-134) registrou conflitos que envolvem a relação intensa entre a universidade e a Organização dos Professores Indígenas de Roraima (Opir), o Conselho Indígena de Roraima (CIR), a Associação dos Povos Indígenas do Estado de Roraima (Apirr) e a Organização das Mulheres Indígenas de Roraima (Omir). No curso de Licenciatura Intercultural, tais organizações desejavam indicar os/as candidatos/as que seriam aprovados nas vagas existentes. Seus argumentos eram que as comunidades conheciam os/as professores e, sendo assim, poderiam indicar os/as que teriam mais compromisso com a educação e com as comunidades. A questão foi resolvida não com o mecanismo da indicação, mas, como ficou registrado no edital do processo seletivo do vestibular específico, pelo quesito da comprovação de relação com a comunidade, que acabou ganhando grande importância na avaliação do currículo dos/as candidatos/as.

Após a aprovação no vestibular, o/a estudante indígena se vale das políticas de permanência (estritamente a Bolsa Permanência: uma ajuda de custo de R \$ 900 que auxiliam o/a estudante a se manter na cidade). Porém esse benefício só é fornecido a quem comprova vínculo com a comunidade, apresentando: declaração de sua respectiva comunidade sobre sua condição de pertencimento étnico, assinada por, pelo menos, três lideranças reconhecidas, e declaração da Funai de que o estudante indígena reside em comunidade indígena, ou comprovante de residência em comunidade indígena. Das universidades federais, apenas a UFRR exige esse tipo de comprovação (LISBOA, 2017a, p. 143-144). Essa regra gerou muitas polêmicas na instituição, resultando, segundo Lisboa, em propostas para novas determinações no Conselho Universitário sobre o tema. Foi sugerido que a anuência da Odic valesse como a de um tuxaua para os/as indígenas que nasceram ou residem em Boa Vista, sem vínculo com 
nenhuma comunidade, ou que fosse paga metade da bolsa permanência para os/as indígenas nessa situação. Enquanto a UFRR não tomava uma posição, os/as alunos/as se valeram de ações judiciais para conseguirem o benefício.

Outro conflito listado por Lisboa parece repetir o problema observado no ensino médio. As comunidades se dividem sobre aceitar um método mais diferenciado, que na visão do professor do Instituto Insikiran Maxim Repetto (2012b, p. 13-30), se traduziria em duas ações, a saber, a transdisciplinaridade e a interculturalidade. Para Repetto, a transdisciplinaridade

\begin{abstract}
busca uma relação compenetrada, mais ainda que na ideia da interdisciplinaridade. Pois se a "interdisciplinaridade", marcada pela preposição "inter", denota "relação entre" campos de conhecimentos, a "transdisciplinaridade" busca superar os limites das disciplinas. A preposição "trans" denota um sentido de ir para "além dos limites" das disciplinas. Um caminho intermediário entre os conhecimentos super objetivados nas disciplinas sem diálogo e nem interação, por um lado, e a sociedade do conhecimento livre, por outro, que, baseado em outras fontes epistemológicas e culturais, poderia imaginar e organizar o conhecimento das formas mais diversas possíveis, sem existir portanto "uma" única visão válida, mas diversas. (p. 16)
\end{abstract}

Nessa possibilidade, as disciplinas compartimentadas deixam de existir e se busca uma aprendizagem sustentada nas necessidades e realidades das comunidades. Pretende-se uma "pedagogia dos projetos" e o ensino por meio da pesquisa, "que implica em produção de conhecimento pelo professor e pela comunidade, estimulando o espírito investigativo (...) e intercambiando resultados com as demais escolas e comunidades indígenas" (LISBOA, 2017a, p. 132).

Numa tal perspectiva, "Quem deve dizer o que serve e o que não é a comunidade e o processo de diagnóstico, diálogo e construção coletiva e participativa" (REPETTO, 2012b, p. 19). No entanto, esses procedimentos exigem uma atenção e reflexão constante por parte dos/as envolvidos/as, o que, segundo Repetto, não se concretizou em sua totalidade, e o desejo de permanecer na zona de conforto das disciplinas se tornava mais atraente. Sendo assim, as dificuldades de implantação da proposta pedagógica do Instituto Insikiran envolveram docentes e estudantes que, ao chegarem às suas comunidades, deparavam-se com uma realidade local onde os comunitários exigiam métodos tradicionais de ensino, contrariando tudo o que aqueles/as estudantes e docentes haviam aprendido.

Pode-se destacar a divergência principal da seguinte forma: de um lado, as que são
favoráveis a um ensino voltado para questões e saberes locais, por meio dos temas
contextuais; de outro, as que defendem o ensino nos moldes da escola tradicional,
como as outras escolas, com o objetivo de preparar os jovens indígenas para o
mercado de trabalho ou o vestibular. (LISBOA, 2017a, p. 134)

As divergências apontadas por Lisboa na disputa por um caminho para os cursos superiores voltados para as realidades indígenas mas que satisfaça os interesses da comunidade - muitas vezes divergentes dos interesses da Universidade - parecem ser difíceis 
de solucionar. Entretanto, podemos pensar nessa divergência como um falso dilema, pois muitas vezes jovens estudam em escolas públicas na periferia das cidades e também não conseguem aprovação em vestibulares ou acesso a bons empregos, mesmo tendo uma formação homogeneizante comum à maioria das escolas públicas de ensino médio.

No mesmo sentido ocorrem divergências nas comunidades que optam por encaminhar filhas e filhos para estudarem no CAM, pois, em minha pesquisa de campo, todas as comunidades visitadas dispunham de ensino médio diferenciado. Essas famílias optavam pelo Câmpus Amajari na perspectiva de fornecer "uma formação melhor" e, assim, encaminhá-los/as para a universidade. Ou, mais frequentemente, esperavam que esses/as jovens retornassem às suas comunidades para, de alguma maneira, contribuir com suas realidades coletivas.

O CAM abriu, então, uma brecha para membros de algumas comunidades que não queriam um ensino diferenciado, seja por não terem um conhecimento adequado sobre seu significado, seja para que pudessem ter uma opção técnica profissionalizante integral que ajudasse esses/as indígenas a terem acesso melhor ao mercado de trabalho e à universidade. A única opção para o ensino técnico na região em que o Câmpus Amajari atua seria o Centro de Formação e Cultura Indígena Raposa Serra do Sol, administrado pelo CIR desde 2006. Todavia, os relatos dos/as estudantes que passaram por esse Centro foram de diversos problemas no prédio e instalações, e de profissionais da educação insuficientes para mantê-lo em funcionamento. Apesar de sua proposta pedagógica ser inovadora e diferenciada, as divergências políticas envolvendo a região do Surumu e do Contão também atraíram os/as alunos/as para o IFRR.

Diante de diversos problemas vivenciados pelas escolas indígenas, em sua maioria sob a administração do governo estadual, o ensino médio indígena diferenciado não consegue se estabelecer como uma unanimidade entre as comunidades indígenas, e isso também atrai estudantes para o CAM.

No capítulo seguinte, apresentarei declarações dos/as estudantes e egressos/as indígenas sobre a experiência de estudarem no CAM, aproximando-nos de seus pontos de vista sobre aprendizagens adquiridas ali. 


\section{CAPÍTULO 3. OS ESTUDANTES MACUXI E SUAS DEMANDAS}

O CAM foi para mim uma experiência única em todos os aspectos, diferente de tudo que eu já havia vivenciado em minha carreira como professor. Tanto no convívio com alunos e alunas indígenas, quanto na vivência de uma estrutura arquitetônica única. Considerando esta última dimensão, Dayrell (2001) descreve em sua pesquisa a arquitetura escolar comumente encontrada em inúmeras escolas públicas brasileiras:

Um primeiro aspecto, que chama a atenção, é o seu isolamento do exterior. Os muros demarcam claramente a passagem entre duas realidades: o mundo da rua e o mundo da escola, como que a tentar separar algo que insiste em se aproximar. A escola tenta se fechar em seu próprio mundo, com suas regras, ritmos e tempos.

O território é construído de forma a levar as pessoas a um destino: através dos corredores, chega-se às salas de aula, o "locus" central do educativo. Assim, boa parte da escola é pensada para uma locomoção rápida, contribuindo para a disciplinarização. A biblioteca fica num canto do prédio, espremida num espaço reduzido. Nenhum local, além da sala de aula, é pensado para atividades pedagógicas. Da mesma forma, a pobreza estética, a falta de cor, de vida, de estímulos visuais, deixam entrever a concepção educativa estreita, confinada à sala de aula e à instrução, tal como afirmamos anteriormente. (p. 13)

O autor considera a arquitetura escolar um elemento constitutivo da "concepção educativa" de uma determinada instituição escolar que, no caso, é compreendida como estreita, pois busca limitar os/as educandos/as à instrução apenas, desconsiderando as possibilidades que um espaço mais integrado aos desejos e vivências da comunidade escolar poderia gerar. A arquitetura do Câmpus Amajari, por sua vez, é composta por diversos elementos contraditórios.

A instituição está localizada a $2 \mathrm{~km}$ da Vila Brasil, circunscrita na sede administrativa do município de Amajari. Assim sendo, ao contrário das demais escolas da região, os alunos e alunas não costumam chegar caminhando, de bicicleta ou de transporte público. Normalmente, o acesso ocorre por ônibus que se deslocam das várias comunidades, com transporte fornecido pelo CAM; ou por carros particulares dos familiares, que trazem seus filhos e filhas. Há ainda a chegada, a pé, do grupo de cem discentes alojados/as na instituição. Logo, a sensação de “isolamento do exterior” à qual o autor se refere é amplificada no câmpus, pois a instituição está afastada das construções do entorno.

Quando chegam, todos/as se deslocam para o restaurante para tomarem o café da manhã. Quem não tem esse direito por morar na Vila Brasil se dirige gradativamente para as salas de aula. A entrada do câmpus é totalmente aberta, não havendo portões que limitam seu acesso. Recentemente, foi construída uma cerca de arame farpado para delimitar os espaços da instituição e fornecer uma sensação de segurança. 
Os/as discentes, ao entrarem, passam pelo "malocão", um espaço em formato circular que simula o mesmo lugar existente nas comunidades indígenas usado para realização de festas, rituais, reuniões, assembleias e aulas. Nesse espaço, sentam-se ou se deitam com seus celulares em bancos que circundam o local, ouvindo músicas em seus fones de ouvido, sozinhos/as ou em grupos ou duplas. Lá também conversam entre si ou com algum servidor ou servidora antes do início das aulas, ou durante o intervalo dos períodos da manhã e da tarde.

Figura 22 - Espaço de convivência chamado de "malocão"

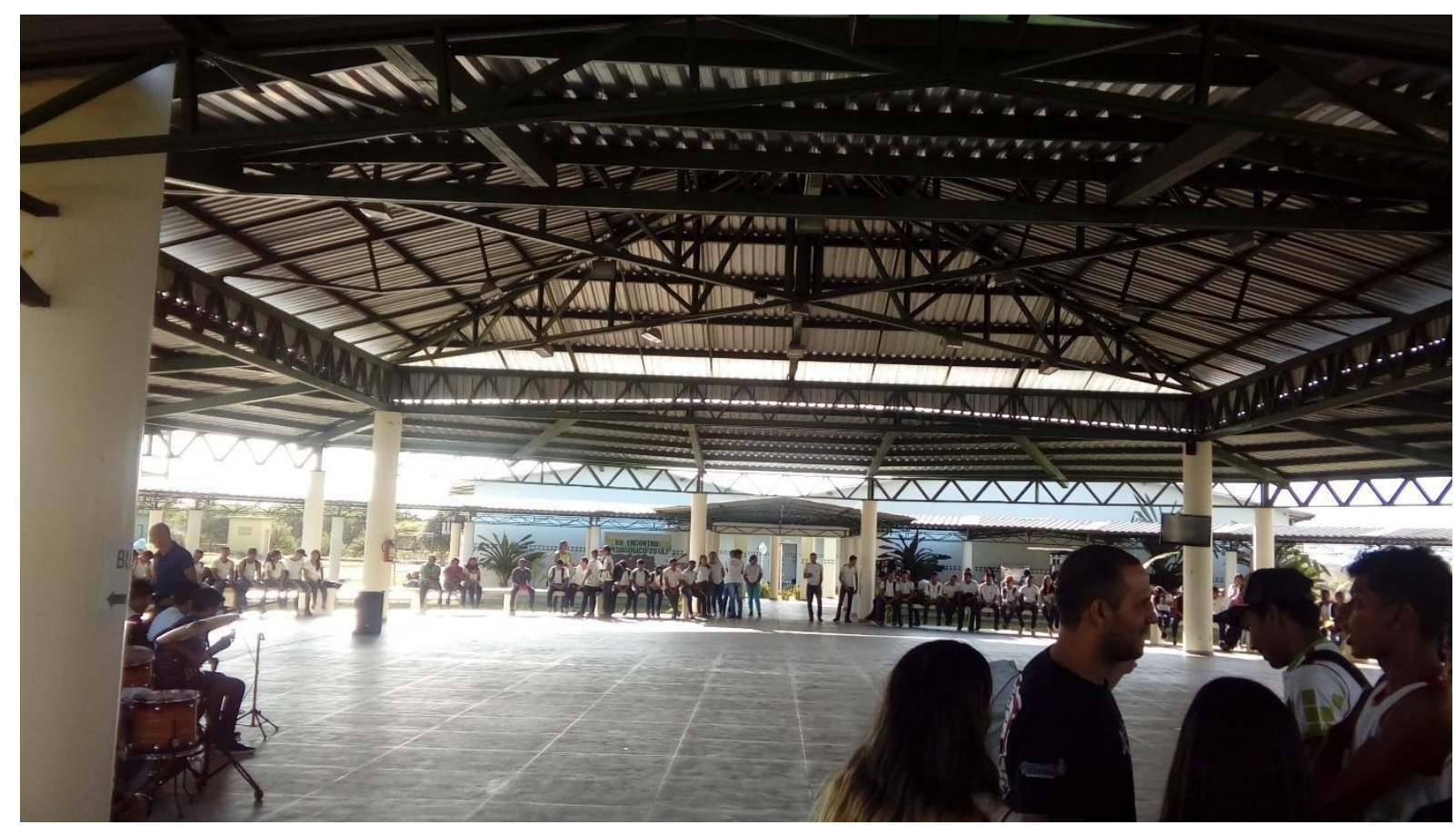

Fonte: Marcos Antônio de Oliveira. Fev. 2018.

Assim como nas comunidades indígenas, esse espaço é usado para realização de várias atividades: exposição de trabalhos dos alunos e alunas, recepção de boas-vindas no início dos semestres letivos, formaturas, palestras, apresentações artísticas, entre outras. A identificação com as comunidades é muito grande, tanto no nome como nas atividades desenvolvidas.

Nesse espaço convergem os corredores que levam às salas de aula, restaurante, laboratório de biologia, informática, sala dos professores, coordenação do ensino superior e biblioteca, esta também usada para apresentação de filmes, reuniões de pais, reuniões de professores e atividades oficiais da instituição. Prefiro acreditar que todos esses eventos deveriam convergir para o espaço de convivência chamado de malocão.

Para Dayrell (2001, p. 5), há duas formas de interpretar alunos e alunas no ambiente escolar: ou como sujeitos socioculturais, ou conforme a "visão homogeneizante e estereotipada 
da noção de aluno". Segundo o autor, os sujeitos socioculturais devem ser compreendidos "na sua diferença, enquanto indivíduo que possui uma historicidade, com visões de mundo, escalas de valores, sentimentos, emoções, desejos, projetos, com lógicas de comportamentos e hábitos que lhe são próprios".

Acreditando na arquitetura que valoriza elementos indígenas existentes nas comunidades locais e tendo em vista a intenção de aproximar-se dessas realidades, a instituição precisa buscar conhecer esse e essa jovem indígena, o que desejam e almejam para seu futuro. Ainda segundo Dayrell:

Em outras palavras, os alunos já chegam à escola com um acúmulo de experiências vivenciadas em múltiplos espaços, através das quais podem elaborar uma cultura própria, uns "óculos" pelo qual vêm, sentem e atribuem sentido e significado ao mundo, à realidade onde se inserem. Não há portanto um mundo real, uma realidade única, pré-existente à atividade mental humana. (2001, p. 6)

Assim, apesar de a arquitetura sugerir um entendimento e desejo de conhecer e se familiarizar com a realidade das comunidades locais, ainda falta o esforço de compreender esses e essas estudantes, de maneira a poder refletir na concepção educativa o que é sugerido pela construção física. Entender a formação do câmpus, mergulhado em uma diversidade cultural que transcende a dimensão étnica. Além de serem indígenas macuxi, esses e essas jovens apresentam projetos de vida que diferem uns dos outros; e incluíram a escola nesses projetos. Ainda segundo Dayrell, "tais implicações desafiam os educadores a desenvolverem posturas e instrumentos metodológicos que possibilitem o aprimoramento do seu olhar sobre o aluno, como 'outro', de tal forma que, conhecendo as dimensões culturais em que ele é diferente, possam resgatar a diferença como tal e não como deficiência” (2001, p. 11).

Além dos espaços mencionados, há aqueles voltados para aulas práticas, que envolvem os tanques de criação de peixes, galinheiros, criação de carneiros, codornas, coelhos e porcos. Os/as discentes circulam nesses espaços livremente com seus equipamentos de segurança. Próximo aos alojamentos masculino e feminino se situa o ginásio esportivo, onde normalmente os alunos e alunas se divertem jogando futebol no início das noites. Lá há também uma pequena academia que os membros da comunidade escolar utilizam.

Tais espaços do câmpus são utilizados de diversas formas, seguindo ou não suas funções iniciais. Não se pode negar a utilização da instituição por parte de alunos e alunas com certa liberdade. Porém os elementos que compõem a cultura escolar ${ }^{64}$ ainda se mantêm,

64 Neste sentido entendida e exemplificada segundo Neto e Lourenço (2017, p. 26): “Os atores (da cultura escolar) são os diferentes sujeitos escolares (professores, alunos, pais, coordenação, direção, serviços), com sua diversa origem social e formação, diferentes faixas etárias e gêneros, suas representações e percursos acadêmicos, sua orientação religiosa e política. É característica do meio escolar o uso de determinado vocabulário e jargões 
tais como a presença do inspetor de alunos, a verificação da utilização das camisetas da instituição, a obediência dos horários incessantes de aulas, a delimitação de algumas salas para a circulação de discentes, enfim, regras que compõem a vida cotidiana de qualquer escola. Entretanto, a especificidade desse lugar e dos/as jovens que o frequentam não permite que ele seja qualquer lugar.

\subsection{Juventudes}

Segundo dados do IBGE de 2010, o Brasil tinha 51,3 milhões de jovens. Desse total, $20 \%$ estavam na faixa etária pertencente à escolaridade média, 15 a 17 anos (NOVAES, 2019, p. 12). As políticas públicas brasileiras consideram jovens as pessoas de 15 a 29 anos. Trata-se de idades determinadas de forma consensual por organismos internacionais e pela legislação brasileira, que, por meio da Lei 11.129 de 30 de junho de 2005, criou a Secretaria Nacional da Juventude, o Conselho Nacional da Juventude e o Programa Nacional de Inclusão de Jovens (Projovem). Tais secretarias e conselho ajudaram na construção do Estatuto da Juventude, que foi criado pela Lei 12.852, de 5 de agosto de 2013. O estatuto, segundo Novaes,

foi resultado de pressões sociais e várias disputas entre concepções de juventude e de finalidade das "políticas públicas". Depois de muitos anos e de várias formulações, no Estatuto da Juventude prevaleceu a concepção de "jovens como sujeitos de direitos" e detalhou-se as responsabilidades do poder público de atuar para assegurar direitos em diferentes dimensões da vida social. $(2019$, p. 11)

Vários autores e autoras se debruçam sobre esse segmento da sociedade. No que diz respeito à faixa etária, diversas obras fazem ressalvas sobre não a considerar como ponto essencial na definição do conceito de juventude.

Márcia Coffani e Cleomar Gomes (2018, p. 9) apontam Pais (1990), Margulis e Urresti (1996), Levi e Schmitt (1996), Groppo (2004), Melluci (2007) e Peralva (2007) como pensadores que se valem dos "contextos sócio-históricos" mais relevantes para compreender a passagem de uma fase da vida, em vez de uma faixa etária determinada universalmente. Semelhantemente, Dayrell e Carrano consideram

que a categoria juventude é parte de um processo de CRESCIMENTO TOTALIZANTE, que ganha contornos específicos no conjunto das experiências vivenciadas pelos indivíduos no seu contexto social. Isso significa entender a

peculiares, verdadeiros códigos partilhados entre os pares, identificáveis em discursos, cartazes, gestos, comunicados, expressões. Da mesma forma, observam-se certas práticas e rituais muito particulares, presentes nas festividades, nas formas de classificação e na avaliação de alunos, na organização curricular, na hierarquia entre disciplinas, na organização e usos do tempo e do espaço. Finalmente, compõem esse quadro os espaços edificados e não edificados - com suas salas de aula, pátios, corredores, jardins, quadras esportivas -, o inconfundível mobiliário e os materiais didáticos". 
juventude mais amplamente e não como uma etapa com um fim predeterminado e muito menos como um momento de preparação que será superado quando se entrar na vida adulta. (2014, p. 11, grifo dos autores)

Os mesmos autores entendem que a juventude tem seu início na adolescência, que "é marcada por transformações biológicas, psicológicas e de inserção social", embora a chegada à vida adulta possa ser adiada, pois as suas características ("terminar os estudos, trabalhar, casar, ter a própria casa e ter filhos") acabam ocorrendo no desenvolvimento da juventude (2014, p. 111). Assim sendo, pode-se dizer que a faixa etária é insuficiente para definir o conceito de juventude.

As considerações anteriores nos remetem ao conceito de "sujeito sociocultural" desenvolvido por Dayrell, a partir do qual cada jovem, provido/a de suas experiências de vida, constrói sua própria identidade. Conceito este que deve ser entendido, na visão de Dayrell e Carrano, dentro

de uma elaboração que cada um vai fazendo por meio das relações que estabelece com
o mundo e com os outros a partir do grupo social a que pertence, do contexto familiar,
das experiências individuais e de acordo com os valores, ideias e normas que
organizam sua visão de mundo. A identidade, nessa perspectiva é, sobretudo, uma
relação social, e, sendo uma INTERAÇÃO, carrega consigo uma tensão irresolúvel
entre o autorreconhecimento e o heterorreconhecimento, que aponta para a
importância do pertencimento grupal e das suas relações solidárias para o reforço e a
garantia da identidade individual. (2014, p. 122-123, grifo dos autores)

Nesse sentido, o conceito de juventude não pode se constituir no singular. Diante das suas variadas composições individuais e coletivas, passo a considerar as juventudes, no sentido de suas diversidades culturais, suas diferenças sociais, educacionais e econômicas. Estou de acordo com os autores quando afirmam que, na "realidade, não há tanto uma juventude, e sim, jovens enquanto sujeitos que a experimentam e a sentem segundo determinado contexto sociocultural onde se inserem e, assim, elaboram determinados modos de ser jovem" (p. 112).

Diante do exposto, pode-se dizer que os/as jovens macuxi não pensam, se organizam ou interagem da mesma maneira que os/as jovens negros/as, imigrantes e migrantes - diferentes grupos cuja situação no cotidiano escolar poderia, à primeira vista, parecer a mesma. Eles e elas são sujeitos socioculturais que adentram o espaço da cultura escolar e pretendem desenvolver uma relação de interculturalidade. Porém a instituição ainda tem dificuldades de vê-los/as dessa maneira.

Segundo os autores, "o esforço de conhecer e reconhecer os jovens estudantes pode levar à descoberta dos jovens reais e corpóreos que habitam a escola e que, em grande medida, podem se afastar das representações negativas dominantes ou das abstrações sobre o 'jovem ideal"' (p. 113). 
Considerando esse conjunto de questões, apresento a seguir uma visão de uma parcela da juventude indígena macuxi que, em sua maioria, habita a TI Raposa Serra do Sol. Recorro a trabalhos acadêmicos realizados por pesquisadores e pesquisadoras indígenas e não indígenas, que produziram etnografias vinculadas à juventude macuxi. Meu intuito é identificar as principais características das vivências em aldeias desses e dessas jovens, representando desse modo os educandos e educandas que entrevistei com profundidade.

\subsection{Juventudes macuxi}

Foram entrevistados/as no total 44 jovens estudantes macuxi. Destes, 22 eram discentes do Câmpus Amajari, sendo 16 rapazes e 6 moças. Também foram entrevistados outros 11 estudantes de escolas indígenas das comunidades Três Corações e Barro, na região do Surumu, e ainda 11 jovens egressos dos cursos integrados de Agropecuária e Aquicultura.

Tais estudantes vêm de famílias numerosas e de formação étnica variada. Alguns têm pais não indígenas ou de etnias diferentes. São em sua maioria cristãos, não falam a língua materna e têm muito contato com tecnologias como celulares, televisão e Internet.

Os/as estudantes da comunidade Três Corações e os/as que vivem na Vila Brasil são mais próximos/as de não indígenas. São duas áreas com muito contato interétnico e ,apesar das dificuldades de acesso à Internet em todo o interior de Roraima, ali a conexão é melhor. Diferente dos/as demais que vivem em regiões mais afastadas, nas Terras Indígenas São Marcos e Raposa Serra do Sol. Na Vila Brasil e na comunidade Três Corações a vivência com pesca e caça é muito pequena, suas atividades agrícolas são exíguas, normalmente trabalham no pequeno comércio da região ou atuam como funcionários/as públicos/as.

No gráfico abaixo, há o número de estudantes do CAM que participaram das entrevistas e cada uma das suas comunidades de origem. Alguns deles viveram nessas comunidades e, quando vieram para o CAM, estavam estudando e morando no Surumu, sob a responsabilidade do tuxaua da região. Por isso tiveram as autorizações fornecidas por cinco tuxauas, apesar de morarem em nove comunidades diferentes. Os/as alunos/as das comunidades Contão e Surumu pertencem, por sua vez, ao município de Pacaraima. A comunidade de Wilimon fica no município de Uiramutã, e as de São Luís e Napoleão situam-se no município de Normandia. As comunidades de Guariba, Aningal e Três Corações e a Vila Brasil pertencem, por fim, à cidade de Amajari. 
Figura 23 - Gráfico: Comunidades e municípios dos/as alunos/as do CAM entrevistados/as

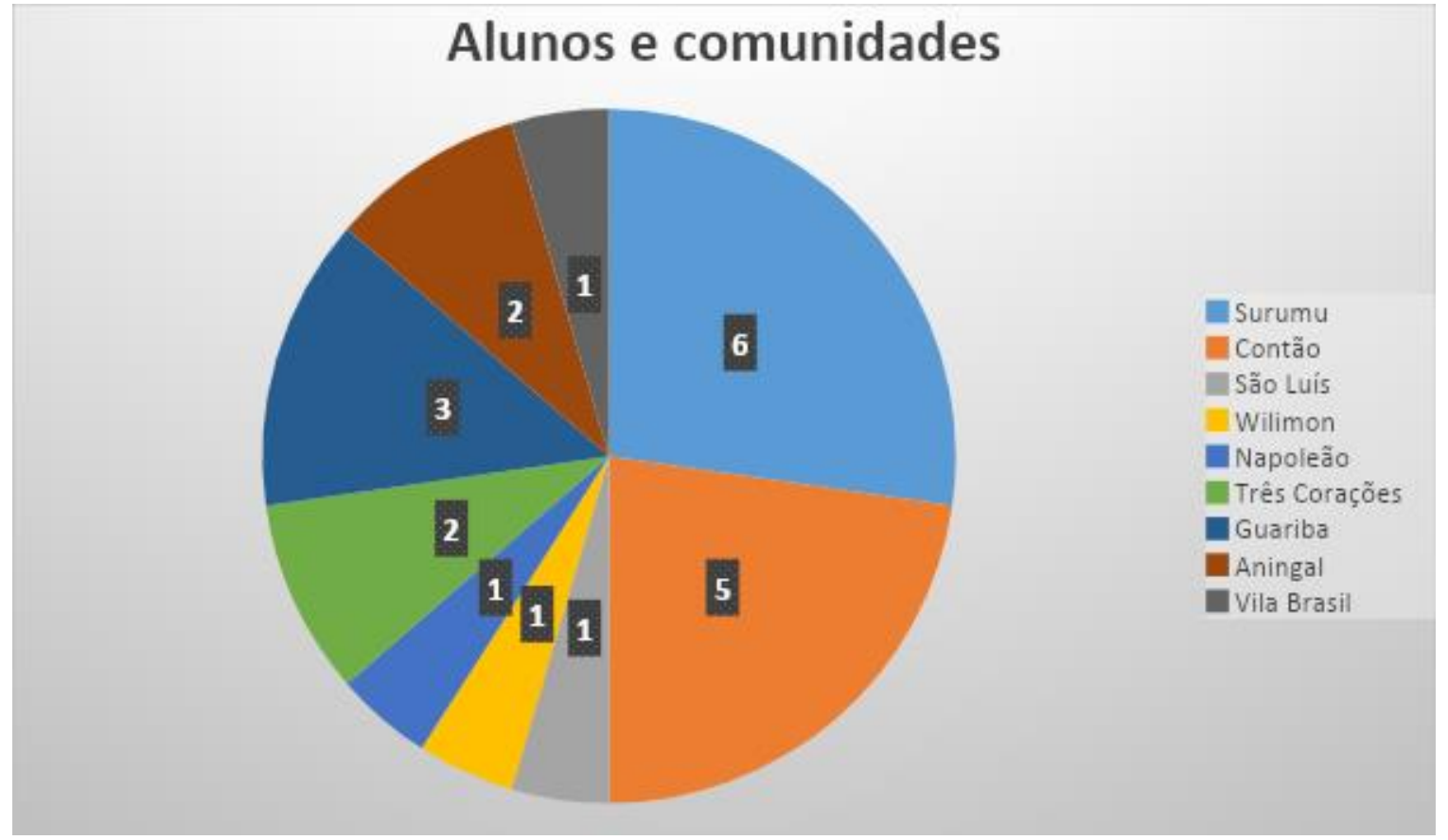

Fonte: Marcos Antônio de Oliveira.

Dos/as 22 estudantes indígenas do CAM entrevistados/as, 16 são da região da TI Raposa Serra do Sol. Já dentre os/as 11 jovens entrevistados/as que frequentavam escolas indígenas locais, 6 eram estudantes da Escola Estadual Indígena Tuxaua Silvestre Messias, nessa mesma TI. Portanto, somou também 22 o número total de estudantes residentes na Raposa Serra do Sol entre meus/minhas 44 entrevistados/as. Apesar de haver uma distância de até $240 \mathrm{~km}$ até o CAM dependendo da comunidade, é uma região com muitos alunos e alunas macuxi.

Para apresentar algumas características dos/as jovens dessa região, utilizo o trabalho etnográfico de Fernandes (2015), que discute a apropriação do forró pelos indígenas macuxi na TI Raposa Serra do Sol, bem como a pesquisa de Peres (2013), que etnografou, na comunidade Boca da Mata, na TI São Marcos, a ressignificação das danças e cantos indígenas macuxi com foco nos jovens da comunidade. Remeto-me também a Andrade (2016) a respeito do processo de conhecimento dos jovens macuxi da comunidade Maruwai, na TI São Marcos. Essas obras possibilitam um panorama da juventude macuxi, que em muito se assemelha ao dos e das jovens que frequentam o CAM. 
Figura 24 - Mapa das Terras Indígenas Raposa Serra do Sol e São Marcos

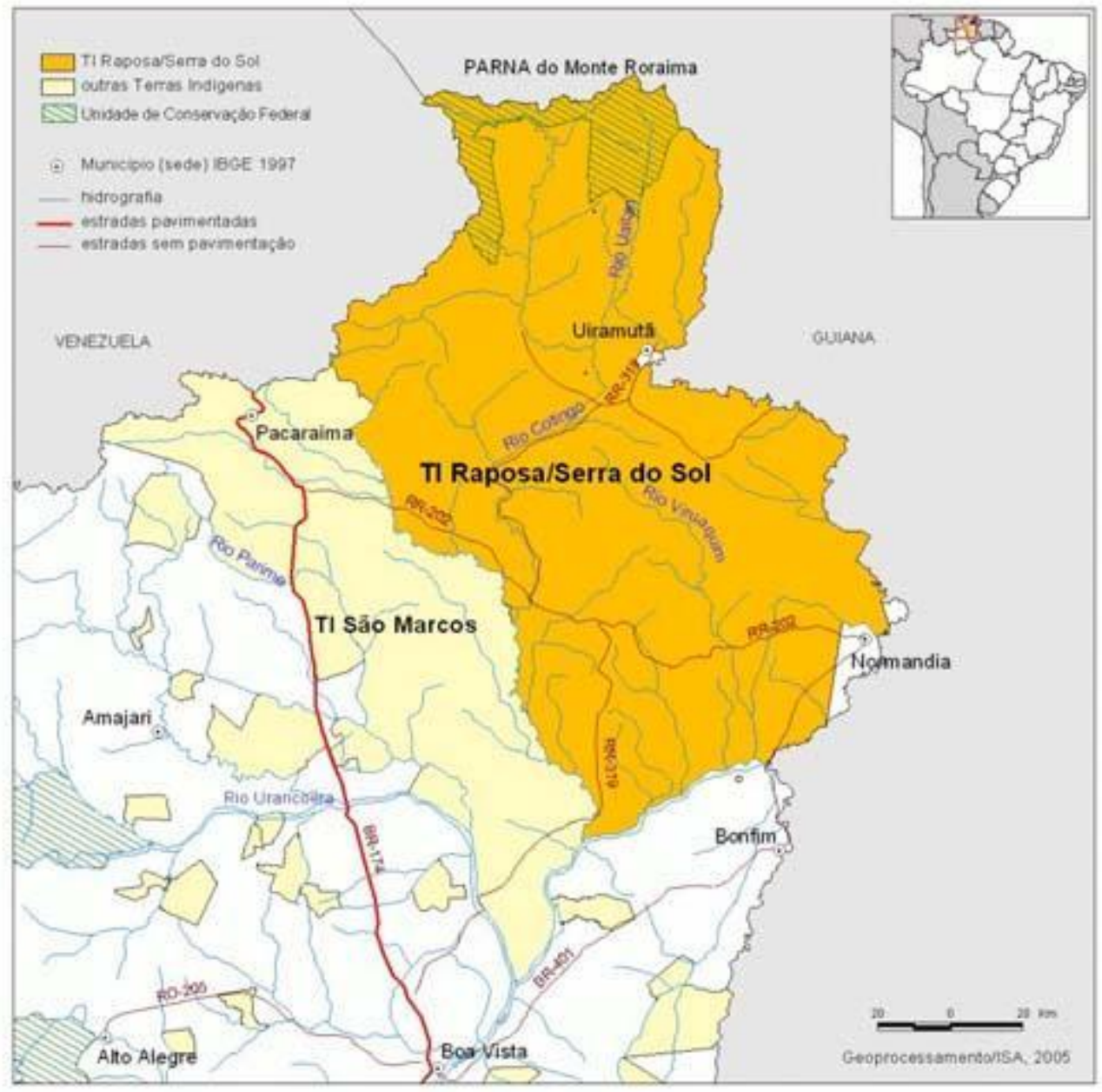

Fonte: FERNANDES, 2015, p. 8.

Os indígenas Kapon e Pemon, que nos séculos XVIII e XIX viviam na região da Guiana Ocidental, foram visitados por inúmeros agentes representantes das potências coloniais do período, atraídos, dentre outros motivos, por interesses territoriais que envolviam essa área. Portugueses, espanhóis, holandeses e ingleses relataram o cotidiano desses povos em suas comunidades em descrições etnográficas ${ }^{65}$ elaboradas pelos pesquisadores, religiosos e militares que circularam por essas regiões de serras e lavrado (FERNANDES, 2015, p. 12).

De acordo com Fernandes, foi descrito o gosto dos povos desse local por festejarem e consumirem uma bebida à base de mandioca, que foi usada para nomear esses festejos

festas de paiwari, que representavam significativo segmento do cotidiano indígena. Paiwari ("piawori”, "paricari”, "paracari”, "pajuarú", "payuá") é o termo utilizado pelo cronista para designar a principal bebida consumida pelos

$65 \mathrm{O}$ antropólogo Felipe M. M. Fernandes recorreu a relatos de cronistas como os irmãos Robert e Richard Schomburgk, Im Thurn, T. Koch-Grünberg, I. Myers, o reverendo anglicano britânico W. H. Brett e o etnomusicólogo alemão Eric von Hornbostel. 
índios durante as festas, produzida à base da raiz da mandioca "brava" (Manihot esculenta), cujo preparo e teor alcoólico se distingue do caxiri, igualmente feita à base de mandioca, consumida cotidianamente. (p. 12)

Essas festas eram marcadas por inúmeras danças e grande quantidade de comida, normalmente oferecida pelos anfitriões, chegando a reunir mais de mil pessoas. Segundo os cronistas estudados por Fernandes, as festividades serviam para atualizar os laços parentais e políticos, reencontrar amigos e realizar matrimônios e trocas comerciais e de conhecimentos rituais $(2015$, p. 13).

Tais eventos tradicionais eram agraciados com danças e cantos como o parichara e o tukui. O parichara "era dedicado a todos os animais de caça, principalmente os quadrúpedes; já o Tukui, o canto do 'beija-flor', era dedicado a todas as aves e a todos os peixes” (p. 18). Conforme os relatos, especialmente do etnógrafo alemão Koch-Grünberg, há uma grande relação entre os mitos de heróis da cosmologia macuxi e as origens desses cantos e danças, atrelados por sua vez a ensinamentos concedidos pelos animais e pelos espíritos protagonistas dos mitos macuxi.

Vale ressaltar que Fernandes relaciona com a imitação e a transferência ${ }^{66}$ o processo de aprendizagem dos cantos e danças fornecidas pelos animais e espíritos (p. 23).

Destarte, cantar e dançar para os índios Pemon e Kapon parece estar além de uma simples "representação" da vida dos animais, mas sugere que durante as performances era possível reviver o tempo mítico, em que humanos e animais não diferiam enquanto constituição física, e, efetivamente, podiam ser tal qual um porco-do-mato, ser um beija-flor, ser um mauarí ${ }^{67}$ - ser um Outro, em síntese. (p. 25)

Tal prática de transferência e aprendizagem na vida dos e das jovens macuxi da comunidade Maruwai, na TI São Marcos, também ocorre na atualidade, quando esses e essas aprendizes vão

ajudar a organizar uma pescaria, ajudar seus pais a escolher o local para fazer a roça, ajudar a construir casa e fazer farinha, isto é, estão sempre acompanhados pelos mais experientes nessas atividades, verifica-se que eles apenas são ajudantes, auxiliares de seus pais ou dos mais velhos e é com essa participação e observância que aprendem como atuar no espaço, no ambiente em que vivem (ANDRADE, 2016, p. 107)

Andrade associa os processos de aprendizagem com os vínculos que esses e essas jovens mantêm com os mais idosos e os que estes mantêm com a natureza. Com base nas estações do

66 Esses conceitos são trazidos de Deleuze (1988) e Tarde (2000). Fernandes supõe uma aproximação entre os conceitos de simulacro, de Deleuze, e imitação, de Tarde, "na medida em que, no limite, as imitações sempre ocultam um continuum de invenção, de diferença, que na aparência e na exterioridade podem não a evidenciar, mas que em sua interioridade, na relação espiritual com o modelo, a 'cópia' é sempre modificada, sempre dissemelhança" (cf. TARDE, 2000, p. 5; DELEUZE, 1988, p. 41-45).

67 Espíritos, alguns deles malévolos, que habitam as serras, rios, lagos, matas etc., e que estabelecem com os humanos uma relação de predação. 
ano, nas fases da lua, no deslocamento das sete estrelas e na presença de determinados animais, nomeiam os meses do ano, realizam as pescarias, a extração de madeira e palha. Paulatinamente, adultos e idosos acompanham esses e essas jovens em atividades, como supervisores, para verificarem suas habilidades e aprendizagens (p. 109).

Tal processo de aprendizagem também era desenvolvido em experiências xamânicas, nas quais, segundo Fernandes (2015), era preciso aprender os sons da natureza e viajar através dos lugares com seu espírito, imitando os animais e os demais elementos que compõem o ambiente das serras ou do lavrado para realizar curas e ajudar os parentes macuxi. A mesma etnografia enuncia a ideia de os Macuxi reproduzirem e darem novos sentidos a influências externas - tanto espirituais, animais e sociais quanto as relações com o "Outro" que, de acordo com o mesmo autor, está refletido nos espíritos maus bem como nos brancos, que, ao mesmo tempo, atraem e causam receio.

Esta aproximação entre os "brancos" e os mauarí parece aludir à superioridade
atribuída aos "brancos", supostamente referenciada à profusão de objetos técnicos, à
abundância de alimentos, saberes musicais, e pelas qualidades sobre-humanas de
imortalidade. Ambos, mauarí e "brancos", em síntese, são os "Outros" arquetípicos -
apetecíveis e perigosos, indesejáveis e indispensáveis, locus do desejo e do receio.
(FERNANDES, 2015, p. 64)

Essa ambiguidade com o elemento exógeno veio alterando as relações com as festividades e com a música, tão apreciada entre os/as jovens macuxi. Fernandes aponta a influência das migrações nordestinas, nos fins do século XIX, e dos religiosos beneditinos, que atuaram ao longo da primeira metade do século $\mathrm{XX}$, nas práticas musicais dos cantos e das danças macuxi (p. 67). Essas influências trouxeram o forró, impulsionado pelos nordestinos, que fugiam das constantes secas, atraídos pelo trabalho no garimpo e na pecuária em Roraima, enquanto os clérigos beneditinos atraíam com seus rituais e cânticos os/as jovens indígenas. Entretanto, o desprezo e a ridicularização dos cantos e das danças - em especial o parichara e o tukui, que eram até então "um sinal de boas vindas a visitantes e convidados" - tanto pelos nordestinos que estavam próximos aos indígenas quanto pelos missionários beneditinos, que associavam esses cantos e danças à bebedeira, brigas e mortes por vingança, fizeram com que desaparecessem dos registros históricos em meados do século XX (p. 78).

O forró acabou se tornando um elemento muito presente nas festas, encontros ou assembleias dos Macuxi, como descreve Andrade na comunidade Maruwai: "Por outro lado, esses jovens não só trabalham, mas participam das festas e se divertem com os mais idosos. Ressalta-se que quando há festas dançantes todos participam: da criança ao colo aos adultos, e eles nomeiam essa festa dançante de 'forró gospel'” (2016, p. 109). 
Peres, referindo-se à comunidade Boca da Mata, que se localiza na TI São Marcos (lugar de onde também vêm alunos e alunas no CAM), assim descreve as festas da comunidade onde o forró acabou prevalecendo como ritmo preferido pelos Macuxi:

\begin{abstract}
As duas maiores festas realizadas na comunidade Boca da Mata são a festa em comemoração ao Natal e a festa junina em homenagem a Santo Antônio que é conhecido como o Arraial do Tonhão. Para a realização desta festa há uma reunião com as comunidades para organizar as barracas para vendas de comidas e bebidas e nestes momentos festivos as comunidades adjacentes sempre estão presentes. As festas e as religiões existentes em Boca da Mata têm influenciado nas mudanças de ser e viver de seus moradores. As danças e os cantos Macuxi passaram a ser substituídas pelo forró. Com isso as danças e os cantos Macuxi passaram a ser realizados de forma esporádica, apenas em ocasiões especiais como em reuniões, assembleias, seminários. (2013, p. 56)
\end{abstract}

Fernandes argumenta que a entrada do forró se deu pelo contato com os fazendeiros, garimpeiros, madeireiros e comerciantes, que traziam rádios e vitrolas para as aldeias na primeira metade do século XX. Assim, os ritmos musicais iam se popularizando entre os Macuxi. Valendo-se de uma divisão social utilizada por Peter Rivière ${ }^{68}$, o autor entende a sociedade roraimense naquele período

entre de um lado os ditos "civilizados" ou "brancos", habitantes da vila de Boa Vista
e das sedes das fazendas, de outro lado, os "índios", que correspondiam à população
aldeada, arredia ao contato. Entre ambas, enquanto categoria "intermediária", os ditos
"caboclos": índios empregados nas fazendas e nos garimpos, e entendidos como
aculturados ou mestiços, por terem adotado costumes e práticas próprias da população
regional, embora não necessariamente miscigenados. (FERNANDES, 2015, p. 82)

O termo "caboclo", até hoje utilizado em Roraima para se referir de forma pejorativa ao indígena local, seria o elemento ocupando uma situação intermediária. Isso porque poderia circular nas festas dos "civilizados" participando como músico, porém impossibilitado de dançar, em virtude do preconceito das moças não indígenas. Enquanto isso, os jovens e adultos não indígenas podiam dançar com as indígenas, circulando inclusive nas diversas aldeias macuxi e levando as músicas e ritmos nordestinos (FERNANDES, 2015, p. 83).

Na segunda metade do século $\mathrm{XX}$, os conflitos com a sociedade roraimense foram se agravando, principalmente nas disputas territoriais. Os povos indígenas foram sendo cerceados em sua caça e pesca e impossibilitados de desenvolver sua agricultura, porque eram ameaçados pelos rebanhos de gado, que destruíam suas roças. Conforme mencionado anteriormente nesta tese, as organizações indígenas, apoiadas principalmente pelo Cimi, com ações da Consolata Brasil, que substituiu os beneditinos, passaram a ajudar os indígenas a incrementar sua autonomia e empoderamento por meio dos projetos, seja de gado, que completa 40 anos em 2020, seja de piscicultura. Diversas criações de animais e produção agrícola permitiram, 
associados à educação específica e diferenciada, a revitalização de práticas tradicionais, como os cantos e danças (SANTILLI, 2001; REPETTO, 2006, 2008b; FREITAS; TORRES, 2016; FREITAS, 2017; RIBEIRO, 2018).

Entendendo que era necessário ressaltar suas características culturais tradicionais como uma maneira de garantir seus direitos indígenas estabelecidos na Constituição Federal, em contraposição ao conceito de caboclo - “associado à noção de 'aculturação', 'mestiçagem' e 'reminiscência étnica', as quais não seriam portadoras de direitos históricos" - as agências indigenistas e as organizações não governamentais iniciaram um processo de "valorização" e "resgate" da cultura tradicional que, segundo Fernandes (2015), se traduz

na eleição de determinados objetos, práticas e saberes próprios dos Makuxi, que
pudessem servir tanto como estímulo econômico - tratando-se de determinadas
práticas de exploração do território -, como também para a formação de uma
identidade étnica, ao estabelecer sinais diacríticos diferenciantes em relação à
sociedade nacional, e que pudessem servir como argumento político central para as
reivindicações territoriais. (p. 94)

Essa opção pelas danças e cantos, como o parichara e o tukui, se dá por representarem elementos cristalizados entre os não indígenas, envolvendo língua materna, indumentária, ritos, cânticos e adornos rituais (p. 94).

A presença das danças e cantos da antiga festa do paiwari ocorre em diversos momentos de festividade, solenidades, encontros, assembleias regionais ou estaduais e até mesmo no CAM, em encontros com representantes da reitoria, em apresentações culturais e em projetos de extensão, assinalados anteriormente. Todavia, tal como indica Fernandes (2015), essas atualizações ficaram muito distantes das características tradicionais desses elementos culturais descritas pelos etnólogos e cronistas. Os instrumentos musicais, os utensílios de caça ornamentados, as vestimentas e, por fim, as pinturas corporais foram atualizadas, e até mesmo as apresentações sofreram alterações no seu período de duração: "nota-se que não há grande interesse dos jovens e crianças nas performances tradicionais - pois os bailes de forró são os preferidos -, o que se percebe pela falta de prática dos bailarinos, que não chegam a dominar todos os meneios das danças ou a memorizar os cantos no vernáculo nativo" (FERNANDES, 2015, p. 98).

Entretanto, o forró, mesmo sofrendo reprimendas dos religiosos por sua relação com o consumo de bebidas alcoólicas, o caxiri e as festas, foi sendo incorporado pelos Macuxi e se tornou um ritmo frequente nas comemorações e reuniões desse povo. Segundo Fernandes, percebendo a ineficiência de sua desaprovação ao forró, os religiosos cederam e, a partir da década de 1970, se houvesse nas composições relação com "os conflitos políticos, os casos de violência, discriminações e desmandos envolvendo índios e regionais", o ritmo seria tolerado. 
Assim surgiu o "forró da maloca" (FERNANDES, 2015, p. 106). Em 2005, foi gravado um CD com composições, intitulado "Caxiri na Cuia: o forró da maloca", e posteriormente foram gravados mais alguns CDs tratando de temas políticos, ou de "cultura indígena" (p. 106-107).

Além do forró com viés politizado, também circula nas comunidades o forró contemporâneo. O ritmo é muito apreciado pelos e pelas jovens macuxi. Dentro das comunidades indígenas, atualmente, apenas músicos macuxi realizam apresentações. Segundo Fernandes,

os jovens Makuxi se empenham em performances musicais de modo a obterem prestígio e, consequentemente, mais convites para outras festas. Além das gratificações recebidas pelas performances, em dinheiro ou em mercadorias - dentre animais bovinos e gêneros alimentícios -, os jovens músicos se engajam nas performances de forró almejando desfrutar das inúmeras viagens, amizades e aventuras amorosas que as festas podem proporcionar. (FERNANDES, 2015, p. 122)

As festas contemporâneas organizadas pelos Macuxi em suas comunidades podem ter variados motivos: de celebrações religiosas, como dias de santos, natal, ano novo e aniversários, até formaturas, construção de postos de saúde, igrejas, escolas, recebimento dos rebanhos dos projetos de gado e comemorações de transmissão do cargo de tuxaua, entre outros. As festas, segundo Fernandes (2015), podem durar de um a dois dias e chegam a reunir mais de mil pessoas, sendo muito parecidas com as festas de paiwari, tendo em vista que seus objetivos ainda são as trocas diversas (comerciais, culturais, afetivas), mas passando por algumas atualizações. A carne de caça, por exemplo, foi substituída pela de boi, e as danças como o parichara e o tukui deram lugar ao forró (p. 127-128).

Peres (2013) discute como os jovens da comunidade Boca da Mata, que contam com um grupo de dança parichara, entendem as ressignificações realizadas nas danças e cantos macuxi. A autora elenca fatores para esse fenômeno na comunidade, tais como a distância dos ensinamentos e convivência com os mais velhos, a proximidade com cidades como Pacaraima, Boa Vista e Santa Helena de Uairén na Venezuela, a influência de religiões cristãs e a permanente convivência com ritmos e danças "urbanas", em especial o forró (PERES, 2013, p. 95). Além disso, ela ressalta que, paulatinamente, tem ocorrido um "esquecimento" dessas práticas "culturais"; e conclui que, a despeito dos esforços de alguns membros das comunidades, não conseguirão permanecer (p. 113).

Há possivelmente no universo da juventude indígena macuxi uma construção de dois perfis, pelo menos. Um seria o/a jovem engajado nas questões políticas que envolveram e envolvem as comunidades indígenas em Roraima. A luta pela terra, saúde e educação. Esses e essas jovens participam de atividades específicas para jovens nas organizações indígenas e nas igrejas e compreendem que sua responsabilidade é manter vivos os elementos culturais macuxi 
restantes e a permanência em suas comunidades, mesmo após saídas esporádicas para realizar a formação educacional. Formação essa que pode reunir muitos perigos para a juventude macuxi. Lisboa (2017b), influenciado pelas metáforas do caçador e do xamã, reflete:

\begin{abstract}
O caçador e o pajé são assim as figuras indígenas de referência com as quais podemos pensar a relação desses povos com o conhecimento. A escola é definitivamente um elemento alienígena e que pouco ou nada contribui nesse universo da caça e das relações com os espíritos. Mas aqui a questão não é a dos conteúdos "que não se aprendem na escola" vs. os conteúdos escolares. Se queremos traçar uma compatibilidade possível entre esses sistemas de conhecimento, creio que devamos olhar, em vez do conteúdo, para a atitude (tanto a ideal quanto a efetiva) dos indígenas perante os mesmos. Sem dúvida ambas atividades, caça e xamanismo, envolvem muitos perigos e truques, requerem iniciação, preparos e habilidades especiais, demandam atenção, esperteza e uma postura respeitosa e cuidadosa quando se está fora da aldeia (ou do corpo). Além disso, é a busca por sinais e respostas e a descoberta de segredos que fazem dessas atividades, essenciais ao mundo indígena, verdadeiras máquinas de conhecer o mundo - sendo a busca pelo conhecimento algo compartilhado por toda a humanidade. Isso faz com que a postura exigida pelos sistemas tradicionais de conhecimento seja transponível e mesmo aplicável ao mundo escolar ou urbano. E se a escola é alienígena, o mesmo não se pode dizer da escola indígena, algo que figura nas falas e documentos das lideranças como um resultado dos seus esforços, uma construção - ainda que inacabada e imperfeita - feita por e para eles. $(2017$, p. 38)
\end{abstract}

Nesse sentido, nem todos que embarcam na viagem de saída das comunidades têm conseguido se manter fiéis às expectativas quanto à luta política e ao engajamento nas organizações. Para caracterizar um segundo perfil dentre os/as jovens macuxi, seriam aqueles vistos pelas lideranças indígenas ou pelos pares engajados como traidores da cultura, ou ainda como individualistas: que não compreendem o sentido da luta anterior à sua existência, luta que lhes garantiu terra e acesso à escola e à universidade.

Tais opiniões me lembram, em nossa sociedade polarizada, a insatisfação com pessoas de direita ou de esquerda que desejam que seus pares sigam o caminho que consideram o ideal, esquecendo que estão lidando com pessoas, que sonham e desejam, às vezes de forma individualizada e não coletiva. O desejo coletivo me parece o mais benéfico a todos; entretanto, em uma sociedade democrática e capitalista, o sonho individual é estimulado e propagado aos quatro ventos e, muitas vezes, apenas o amadurecimento nos traz ao entendimento de nosso objetivo social. Esses e essas jovens macuxi parecem caminhar para isso.

Eles/as têm uma família formada, frequentemente, por mãe indígena e pai não indígena, ou de etnias diferentes, que não falam mais suas línguas originárias e não conservam nenhum elemento cultural tradicional. Assumem, às vezes a contragosto, sua identidade étnica para usufruir dos benefícios das cotas às quais têm direito.

Andrade (2016) entrevistou 10 jovens macuxi da comunidade Maruwai, perguntando sobre seus interesses e sonhos enquanto estavam no ensino médio e como desejavam viver após essa fase escolar. Nas entrevistas apresentadas, há desejos de se formar em diversas profissões 
como dentista, psicóloga, enfermeira, médico, soldado, empresário, técnico em enfermagem ou jogador de futebol. Embora haja interesses estritamente pessoais como, por exemplo, almejar uma melhora econômica para poder obter mais conforto e bens de consumo, todos incluíram a continuidade da escolarização entre os desejos que apresentaram para o futuro. Todos tinham em seus planos o ensino formal acadêmico para alcançar seus objetivos pessoais (ANDRADE, 2015, p. 110-111). Trata-se de desejos e anseios muito parecidos com os de jovens estudantes macuxi que chegam ao CAM, com projetos de futuro que apresentarei a seguir, obtidos nas entrevistas que realizei nesta pesquisa.

Esses/as jovens macuxi apresentam inicialmente em suas falas uma forte influência externa para sua motivação de ida ao CAM, vindo de familiares e amigos/as. Todavia, durante seus percursos acadêmicos, foram sendo estimulados/as pela instituição ou compreenderam que a sequência de seus estudos em universidades seria viável para seus projetos pessoais. Assim muitos deles/as foram adiando ou excluindo a possibilidade de retorno às suas comunidades, o que inicialmente, os/as levara até o CAM.

Meu objetivo é visibilizar os interesses e cotidianos desses e dessas jovens, antes e durante suas passagens pelo CAM. Assim, poderemos chegar mais perto do nosso sujeito sociocultural e ir além do entendimento dos/as jovens macuxi apenas como nossos alunos e alunas.

\subsection{Jovens macuxi no CAM}

Inicialmente vou apresentar a bagagem que esses (as) alunos/as trazem de suas regiões de origem, suas experiências em suas localidades e suas percepções sobre o universo que habitavam antes da chegada à instituição. Uma parte vivendo em regiões rurais e outros/as em ambientes mais urbanizados. Sobre jovens, segundo Dayrell (2001, p. 6), “O que cada um deles é, ao chegar à escola, é fruto de um conjunto de experiências sociais vivenciadas nos mais diferentes espaços sociais. Assim, para compreendê-lo, temos de levar em conta a dimensão da experiência vivida". Compreendê-los/as como sujeitos sociais exige essa consideração.

As entrevistas descritas nesta tese com alunos/as macuxi foram realizadas dentro das instituições escolares às quais eles/as pertenciam. Geralmente foram realizadas com os/as estudantes do CAM nos meses de fevereiro e março de 2018, durante períodos em que os/as discentes estavam em aulas vagas. Essas entrevistas foram realizadas na biblioteca, na sala dos professores ou, em uma das ocasiões, com os alunos da alternância, em seu alojamento.

Na escola Santa Luzia, comunidade Três Corações, as entrevistas foram realizadas em um único momento com um grupo de 5 alunos/as, em 2019, que estavam sem aulas por 
problemas relacionados à contratação de professores e professor/as. O gestor da instituição gentilmente reuniu o grupo de alunos e alunas que se dispôs a participar da entrevista e, por morarem próximos a à escola, comparecerem para nossa conversa.

Na escola Tuxaua Silvestre Messias, na comunidade do Barro, as entrevistas realizadas com 5 estudantes foram feitas durante o mês de fevereiro de 2020. O gestor preparou as turmas de ensino médio, que tinham aulas no período da tarde, e os/as alunos/as se dispuseram a participar das entrevistas.

Esses/as estudantes relataram como era seu cotidiano em suas comunidades de origem. Um deles descreveu sua infância no Contão:

Tem rio, legal lá, meu pai fazia pra gente fazer pescaria, a gente pescava. Aí o meu pai, um dia ele fez uma roça de melancia, faz tempo... Mas lá era legal do outro lado, eu achava muito legal, a gente toda manhã, quando acordava, a gente ouvia os passarinhos cantando. ${ }^{69}$

Outro contou sobre suas brincadeiras na mesma região: “Andando de bicicleta. É muito tranquilo lá. Eu fico o dia todo no rio... Praia, tem uma praia lá no Rio Cotingo". ${ }^{70}$

Uma adolescente que reside na comunidade Três Corações mencionou os períodos que ficava em casa: "Em casa eu tenho Internet, aí eu fico assim, lá em casa, ou no celular ou no caderno. Aí eu não escolho nem celular e nem caderno, e vou para a televisão, é quando eu vou parar pra ver outra coisa". ${ }^{71}$

Duas adolescentes macuxi descreveram suas origens e a região em que vivem em um poema que escreveram e publicaram em um livro resultante do projeto chamado "Cordel Intercultural: Produção Literária do/no IFRR Câmpus Amajari”, realizado em 2017 pelo professor e a professora de Língua Portuguesa do CAM. Nesse livro, relatam o lugar de onde vieram, suas infâncias, suas tradições e costumes.

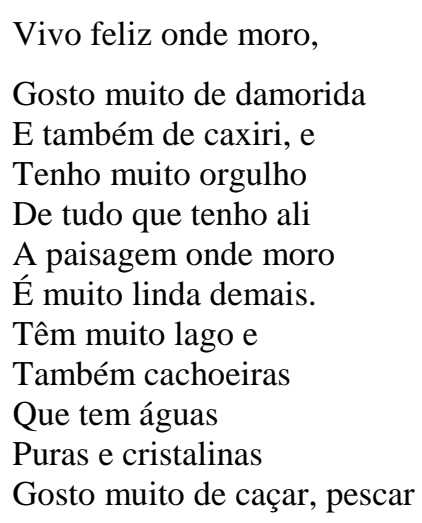

69 Entrevista ao autor, fev. 2018.

70 Entrevista ao autor, fev. 2018.

71 Entrevista ao autor, mar. 2018. 
E dançar parichara,

Pois sou muito feliz

Andando de Kaware

Campeando meu gado,

E matando prawin ${ }^{72}$

Um segundo grupo de adolescentes macuxi descreveu sua região e sua infância:

Onde moro tem serra,

Tem lagos e igarapés,

Pássaros de montão lá tem

Papagaios, curicaca e jacamim

Paca, capivara, tatu e jabuti.

Todo dia trabalhando a sol

Plantando minhas manivas,

Mas não sou escravo.

Essa é minha cultura

Torro farinha, beiju.

Tomando caxiri e pajuaru. ${ }^{73}$

As falas dos/as estudantes ainda explicam lugares com caça, pesca e vários momentos de diversão em rios. Os que estão mais próximos das estradas e têm mais contato com os não indígenas passam suas horas na Internet e na programação da TV, mesmo ali onde a energia elétrica é inconstante. Também falam das festas das comunidades, onde se reúnem para comer, encontrar os amigos e ouvir músicas, principalmente o forró, que, como vimos, é um dos ritmos preferidos da juventude macuxi. Uma jovem macuxi narra em seu poema essas festividades:

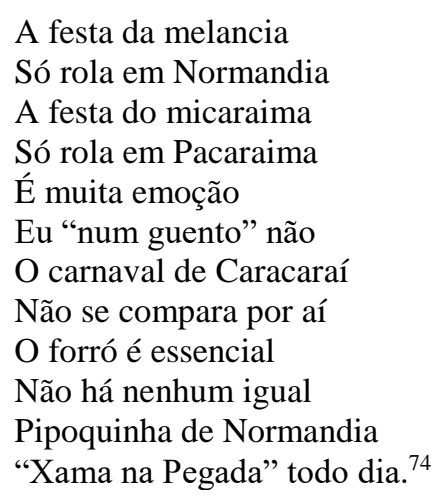

Estudantes da Escola Estadual Indígena Tuxaua Silvestre Messias, na comunidade do Barro, comentaram sobre seus espaços de sociabilidade na comunidade e do que gostavam de fazer para se divertir: "Jogar bola, Internet... banho no rio. Festejos da comunidade... coisas de cavalo. Os festejos acontecem na praça. É isso". 75

72 IFRR. Interculturalidade em versos. Amajari: IFRR Câmpus Amajari, 2018. p. 20.

73 Ibid., p. 37.

74 IFRR. Interculturalidade em versos. Amajari: IFRR Câmpus Amajari, 2018. p. 50.

75 Entrevista ao autor, fev. 2020. 
Vivendo em universos marcados pelo trabalho agrícola, em que a produção não é muito intensa, ou na criação de gado para quem possui rebanho, esses/as jovens macuxi viviam em suas comunidades, de acordo o que descreveram, em regiões nas quais podiam ter contato com a natureza e com elementos do espaço não indígena, mesmo morando em comunidades distantes.

Os pais desses/as jovens são de diversas origens. Alguns são filhos/as de indígenas com não indígenas, outros/as de pais de etnias diferentes e de formação profissional diversificada. No entanto, a presença de pais professores/as ou vinculados/as ao serviço público pareceu relevante. Alguns Macuxi detalharam suas famílias e o contato com a agricultura e a formação educacional desde cedo, como no caso desse jovem macuxi do Surumu:

Bom, é trabalho mais de agricultura, tem a roça, tem horta. Meu pai é professor do estado, a minha mãe também é concursada... Bom, pela formação do meu pai e da minha mãe, assim, sempre quando a minha mãe vinha pra faculdade, eu vinha com ela, porque aí eu não podia ficar só, lá em casa, a gente era muito novo... Bom... desde da infância que eu gosto de trabalhar com os animais e tal. Meu avô tem uma pequena propriedade, eu sempre vou lá, e eu vejo que meu avô sempre tem alguma dificuldade, entendeu? Na questão de rebanho e tal, e eu vou ajudar o meu avô de uma certa forma. $^{76}$

Um jovem, nascido em Boa Vista, contou sobre sua infância com os pais, marcada pela presença da escola tanto na vida dos pais quanto na dele, quando foi morar no Surumu, a partir dos 8 anos de idade.

Eu nasci em Boa Vista. Só que eu morava em uma comunidade. Daí, só que quando eu morava lá, eu era pequeno, aí minha mãe foi com eles estudar pra ser professora. Aí saí de lá e fui morar com minha vó, aqui na fronteira com o Rio (Surumu). É. Aí, eu passei poucos dias com a minha vó, aí vim morar aqui, já com 8 anos. Aí eu já estava na $2^{\mathrm{a}}$ série, eu fiz a $1^{\mathrm{a}}$ série, lá na minha outra comunidade... A minha mãe, depois que ela terminou o estudo, agora ela virou professora, ela trabalha em região, ela é diretora daqui dos professores da região... Meu pai trabalha de bico, mesmo, ele tem a oficina dele. Ele tinha um carro, e trabalhava de fazer bico, fazia móveis, prédios. $^{77}$

Uma jovem macuxi relacionou sua trajetória com a formação dos seus pais.

Eu tenho 15 anos. Eu tenho nove irmãos que moram comigo. Eu moro na comunidade Três Corações. Só a minha mãe que fala (macuxi), e eu tenho um irmão que é professor de língua macuxi e wapichana. Ela (mãe) não conseguiu se formar, porque ela ficou grávida, e aí... ela também começou a trabalhar, e a diretora não deixou ela sair, e tal hora ela tinha que trabalhar. Aí, ela parou. Meu pai é chefe do pessoal da saúde. ${ }^{78}$

76 Entrevista ao autor, fev. 2018.

77 Entrevista ao autor, fev. 2018.

78 Entrevista ao autor, mar. 2018. 
Um aluno do curso integrado em Agropecuária também comentou sobre seu núcleo familiar:

Tenho 16 anos, sou descendente de Macuxi. Minha mãe é indígena, só que meu pai ele é maranhense, veio do Maranhão, de lá pra cá. Aí, minha mãe começou a morar, assim, em comunidade indígena, depois que minha mãe passou no concurso. A gente já morou em São Luís, no 100, em várias cidades, menos na comunidade, mas agora estamos morando no Guariba, porque a gente decidiu morar, porque lá é mais perto de Boa Vista, e lá é bom, tem local pra gente ficar, os nossos familiares que estão com a gente. ${ }^{79}$

Outro jovem do Surumu descreve sua família:

Meu pai é maranhense e minha mãe é Macuxi, só que ela é do Surumu. É dona de casa. Ele (pai) praticamente não trabalha em nada, só fica em casa, mas ele já está velhinho, 74 anos já. Ele chegou a se aposentar ano passado. Planta, tem uns pés de banana pra comer. É, pra consumo mesmo. ${ }^{80}$

Os relatos sobre o universo familiar contêm algumas características de alunos/as que frequentam o CAM. Várias são famílias com casamentos mistos, envolvendo não índios ou indígenas de etnias diferentes. Possuem um número grande de irmãos e irmãs, não falam a língua indígena em seu núcleo familiar, algumas são pequenas proprietárias e realizam uma agricultura de subsistência.

Ainda é possível ver que a maioria pertence a alguma religião de matriz cristã e tem a educação como motivação de deslocamento de seus pais para estudarem na capital ou em localidades distantes de suas comunidades de nascimento.

Pode-se dizer que, nas entrevistas, os motivos que trouxeram os estudantes ao CAM se referem à busca de um ensino de melhor qualidade e à possibilidade de adquirir uma profissão ao final do curso. Um adolescente da comunidade do Barro revelou sua opinião a respeito do Instituto, referindo-se à escola indígena de forma negativa:

Aí, a minha mãe por influência da mãe dele, falava que aqui era bom, que o ensino era de qualidade, aí eu vim também, mas por causa da nossa escola, tava tudo atrasado né, tava tudo correndo contra o tempo lá pra terminar as aulas, aí eu quis vir pra cá. ${ }^{81}$

Outro jovem da comunidade São Luís, próxima da cidade de Uiramutã, listou seus motivos para estudar no CAM: “Aí, eu resolvi vir para buscar melhores oportunidades, levar

79 Entrevista ao autor, fev. 2018.

80 Entrevista ao autor, fev. 2018.

81 Entrevista ao autor, fev. 2018. 
meu projeto pra lá, também, um projeto de piscicultura e de agricultura, vou levar pra lá, meu projeto pra comunidade" $" 82$.

Um adolescente do Surumu também expôs suas opiniões sobre a escola de sua comunidade: "Na verdade... Não tem professores, tem muita gente, não tem a qualidade dos professores daqui e lá é meio desorganizado... Eu vim pra cá por causa da qualidade daqui, dos professores...".83

Um Macuxi também se referiu à possibilidade de ter condições de utilizar os conhecimentos do curso de Agropecuária em sua comunidade, no Guariba, e em sua própria residência, em uma roça própria.

Eu sempre ouvia falar do Instituto, que trabalhava muito, que o Instituto aqui era só pra estudar, mas eu não sabia muito... eu ouvia falar do Instituto era pelos professores que falava do Instituto. Aí, eles falavam que tinha esse curso de Agropecuária, aí eu comecei a me interessar, porque lá na escola sempre tinha algo pra gente fazer, e como lá em casa minha mãe planta bananeira, tem uns canteiros, aí eu decidi vir. Aí, eu comecei a criar esse negócio de terminar o ensino médio e já querer trabalhar. Aí, eu vendo que se eu continuasse no Guariba, eu tinha que fazer outro curso pra conseguir emprego, e eu vindo pra cá eu saía com o curso e com o ensino médio concluído, já era, assim, meio caminho andado. ${ }^{84}$

Mais um adolescente, que já havia cursado dois anos no Centro Indígena de Formação e Cultura Raposa Serra do Sol, também deixou o curso e veio para o CAM. Ele descreveu seus motivos:

E, quando eu estava no Surumu, foi que lá é uma escola que é bancada pelas religiões lá do povo (CIFCRSS). E aí, eu tinha muitos colegas lá, até um pessoal de fora que falava que a gente não tinha capacidade de vir pro Instituto Federal. Aí eu falei: "Vou fazer o seletivo, pra eu ver se eu passo. Se eu passar tudo bem, se eu não passar, eu vou continuar estudando na minha mesma área que eu estou, está de boa pra mim". Aí, peguei, fiz o processo seletivo e passei... Bom, então eu optei em conhecer o Instituto, vim e conheci, e vi coisas totalmente diferentes, até que, como subiram tanto, alguns colegas meus, que eu conhecia também, me perguntaram se era bom, e eu falei que é, é uma escola pra quem quer estudar mesmo. É pra quem quer estudar de manhã e de tarde, de manhã e de tarde. ${ }^{85}$

A maioria deles foi incentivada pelos pais e mães, amigos/as e colegas, que já estudavam no CAM, sempre com a perspectiva de, formando-se na instituição, terem mais chances de ingressar no ensino superior, tendo como referência a qualidade de ensino do câmpus e a depreciação das escolas indígenas de suas comunidades.

82 Entrevista ao autor, fev. 2018.

83 Entrevista ao autor, fev. 2018.

84 Entrevista ao autor, mar. 2018.

85 Entrevista ao autor, mar. 2018. 
Uma garota macuxi de 15 anos indicou a influência de sua mãe no seu ingresso no curso de Agropecuária no CAM:

A mamãe fez, aí ela falou que pra mim era o melhor, porque eu ia aprender a mexer com muita coisa, porque eu gosto de brincar de areia, aí ela fala que eu ainda sou criança, mas não é, é porque é costume mesmo. Aí, eu pego e fico brincando, aí ela me falou que era pra fazer o de Agropecuária que eu ia mexer com areia, mexer com boi. Aí, na hora que ela falou isso pra mim, de mexer com boi, eu falei que "não quero mais não", porque eu morro de medo de bicho. Aí eu falei: "Eu não quero mais não". Aí ela falou que esse curso era o melhor, que eu ia ter que escolher, aí eu perguntei qual era o outro curso, e ela falou que era Aquicultura, que eu ia mexer com peixe, aí eu falei que não, que não ia fazer mais não. Aí, ela falou assim: "Não, você vai fazer", aí eu peguei e me inscrevi em Agropecuária. ${ }^{86}$

Outro garoto destacou a influência de seu pai em sua difícil decisão de vir estudar no

Instituto:

Aí meu pai ouviu assim, e botou meu nome, aí eu estava dormindo lá em casa, aí chegou lá ele me acordou e perguntou se eu queria ir pra lá, eu também nem conhecia o alojamento. Aí, perguntou se eu queria vir estudar e vir ficar estudando por... pra cá, aí eu fiquei pensando, será que eu devo, deixar vocês e vovô. Só depois de um tempo, foi que eu resolvi ir, aí então eu fiz a minha inscrição e pronto. ${ }^{87}$

Uma jovem macuxi que estava no $1^{\circ}$ ano em Agropecuária falou sobre o papel do pai em sua escolha de estudar no CAM. "Eu me inscrevi, por causa de meu pai, que meu pai queria uma filha veterinária, aí eu me inscrevi em Agropecuária." 88

Um jovem macuxi de 16 anos, da comunidade São Luiz, que já estava cursando o ensino médio, revelou a influência de uma professora quando optou por reiniciar o curso no CAM:

Na verdade, eu estava estudando, eu terminei o ensino fundamental, e o ensino médio eu fui pra comunidade da Enseada. Aí eu já estava estudando, e quando chegou a inscrição do Instituto... Aí, a professora chegou pra nós, porque eram três alunos querendo vir pra cá, aí eu me meti no meio também, aí consegui. Aí, eu resolvi vir para buscar melhores oportunidades... Eles (pais) acharam bom, sair de casa pra buscar um estudo melhor. $\mathrm{Na}$ verdade, eu não queria não, mas como a professora precisava, aí eu vim pra cá. ${ }^{89}$

Seguem algumas opiniões desses/as estudantes sobre as escolas de suas comunidades de origem:

Aí, eu entrei também por causa do estudo mesmo que teve um tempo que a maioria
das escolas estavam em greve e já estava um bom tempo sem aula já, tipo, nós tivemos
que fazer tipo uma aceleração pra terminar o $9^{\circ}$ ano. Aí, nós fizemos e pronto, aí
entrou o Instituto. Aí, no que eu ia passar pra lá (CIFCRSS), pra passar pra essa fase,
de novo, tipo, ficar atrasado nas aulas. Aí eu pensei nisso também, se eu for pra lá,
que eu já ia começar as aulas em fevereiro, e ainda tava de férias. Aí eu resolvi entrar,

86 Entrevista ao autor, mar. 2018.

87 Entrevista ao autor, fev. 2018.

88 Entrevista ao autor, fev. 2018.

89 Entrevista ao autor, fev. 2018. 
aí eu vim embora pra cá também pelos estudos, os professores não eram de qualidade, poder dizer né.

- É, porque lá (Surumu) o ensino falta muito professor, e a escola é um pouco ruim.

Pelo que eu estou vendo da escola que eu estava (Guariba). A escola mudou, mudaram os professores, mudaram tudo. Depois que eu vim pra cá, eu aprendi coisas que eu nem nunca tinha visto antes... E quase não tinha muita aula.

Porque eu vi que não ia pra frente. Porque até metade dos alunos já foram embora. Aí, eu falei: eu não vou ficar aqui (Três Corações) pra não aprender nada, porque eu não estava aprendendo mais nada.

Minha mãe sempre quis que eu estudasse lá (CIFCRSS), porque ela dava aula lá, e ela vem de lá e saiu. Aí, eu falei que eu não queria ir pra lá, devido às consequências de lá, estava baixando uns negócios lá que estava acontecendo, meio... as coordenações já não estavam andando meio no caminho certo.

Eu gostei, porque tinha os amigos. Mas sempre faltava professores, porque tinha problemas de salários, falta de merenda, falta de livro didático. Mas a minha mãe sempre fez vaquinha pra comprar material pra nossa escola, porque era mais de difícil acesso. Eu lembro que lá, a merenda chegava suja, porque a estrada era ruim.

Aí, sempre teve essas dificuldades, mas foi legal, deu pra aprender.

Não tem professores, tem muita gente, não tem a qualidade dos professores daqui, e lá é meio desorganizado. ${ }^{90}$

Em entrevista com alunos do $3^{\circ}$ ano regular do ensino médio da Escola Estadual Indígena Tuxaua Silvestre Messias, cuja turma tem oito alunos/as, na comunidade do Barro, um estudante de 17 anos avaliou sua unidade escolar:

É regular, bem abaixo do padrão... Em questão de estudo acho que ainda está um pouco atrasado, tem escolas que são melhores. No meu ponto de vista, mais pela parte dos professores mesmo, de estrutura. Aqui não tem um laboratório. Até em questão de estrutura mesmo a escola está abaixo do padrão exigido para um aluno aprender bem. Isso acaba influenciando. Porque na hora que a gente está, sei lá, em uma aula de ciências não dá para usar um laboratório porque não tem. Na hora que a gente está estudando história, por exemplo. Tem uma biblioteca, mas não é essas coisas. É isso. ${ }^{91}$

O descaso do governo estadual em relação às escolas indígenas das comunidades acarreta a falta de professores, ora porque não são selecionados substitutos em tempo hábil ao início do ano letivo, ou porque não são realizados concursos diferenciados para indígenas, conforme solicitado pelas comunidades. Além disso, as escolas indígenas não apresentam instalações adequadas para o ensino médio.

O ano letivo de 2019 ainda estava em curso em fevereiro de 2020 quando realizei as entrevistas com alunos/as na comunidade do Barro e com o gestor da Escola Estadual José Marcolino, do Contão, em razão do atraso do início do ano letivo anterior, que somente teve seu começo em maio de 2019, devido à ausência de professores/as concursados/as ou aprovados/as em processo seletivo. Assim, o magistério faz greves frequentemente exigindo 
tais direitos, e passam-se muitos dias sem aulas. Tudo isso incentiva uma avaliação negativa nos/as jovens macuxi, e também em seus familiares, em relação às instituições de ensino pertencentes às suas comunidades. Isso, em contrapartida, possibilita uma impressão positiva sobre o CAM, sugerindo que o Instituto Federal tem melhores condições de ensino, professores e condições materiais.

É necessário refletir sobre as expectativas que foram depositadas na educação escolar, paulatinamente reformuladas a partir das lutas dos povos indígenas nos anos de 1970 e 1980 . A escola antes era vista como instrumento de opressão e colonização e foi, em uma tentativa de reformulação, passando a ser usada para valorização e fortalecimento da cultura e das tradições dos povos indígenas. A busca de uma educação escolar indígena diferenciada procurou possibilitar aos habitantes das terras indígenas uma forma de melhorarem suas vidas e de seus filhos e filhas, mantendo as características de suas tradições culturais. Repetto (2006, p. 58) aponta divergências geracionais a respeito do conceito de "melhorar de vida":

\begin{abstract}
Assim é que, para importantes segmentos da sociedade makuxi, melhorar a vida significa homologação e demarcação de terras indígenas, as quais são a base de sua própria vida. E isso se traduz, em última instância, na valorização do trabalho e da cultura. Já para outros setores indígenas, essa valorização cultural, que virá a reboque do processo de homologação, significa atraso, e a "escola deveria preparar o aluno para o mercado de trabalho no mundo dos brancos".
\end{abstract}

O mesmo Repetto (2006, p. 77) já apontava uma expectativa em torno da juventude como uma peça fundamental para "desenvolver" as comunidades; todavia, essas expectativas foram frustradas diante da incapacidade de serem atendidas pela educação escolar, ainda que haja 260 escolas indígenas de ensino fundamental e médio em Roraima, perfazendo um total de 16 mil alunos/as.

Tais escolas foram criadas visando a fazer frente às dificuldades surgidas nas diversas terras indígenas marcadas por problemas ambientais, limites fundiários fixos, estabilidades das comunidades acompanhadas de aumento da população, e técnicas agrícolas incapazes de atender às demandas das comunidades. Os/as jovens, auxiliados/as pela educação escolar, passaram a serem vistos/as como quem poderia lidar melhor com uma realidade em que se precisava criar os peixes para se reproduzirem, tornar as roças tradicionais mais produtivas com novas tecnologias, romper com a dependência das sementes do governo e, "consequentemente, com o clientelismo típico das relações mantidas até então com a sociedade regional” (idem, p. 79).

As comunidades esperam que a escola indígena, de modo geral, e o EM, de modo particular, possam estimular a juventude na valorização do que lhes pertence. Esperam, ainda, que a escola seja capaz de oferecer ferramentas para que os jovens possam tornar as condições socioambientais mais favoráveis. Espera-se, enfim, que 
seja responsável pelo rompimento com a tradição de dependência eleitoreira, mantida por meio de discursos pretensamente desenvolvimentistas, mas que na prática nunca se concretizam em melhorias nas condições de vida das famílias indígenas. (REPETTO, 2006, p.80)

Para essas expectativas, as realidades encontradas nas comunidades indígenas não eram muito animadoras. Repetto (2006, p.79) constatou que as maiores queixas das lideranças, pais e alunos/as das escolas indígenas de ensino médio eram quanto a não conseguirem trabalho nas comunidades e nem na capital, o que fazia, na interpretação deles/as, que esse segmento da educação básica fosse considerado desnecessário.

As comunidades, de uma maneira geral, começaram a se interessar por um ensino médio profissionalizante, que pudesse de alguma maneira corresponder às expectativas que estavam sendo criadas em torno da juventude e da educação escolar. Segundo Repetto (2006, p. 81), havia "um desejo comum de preparar os jovens com novos conhecimentos para enfrentar os atuais desafios de vida e de produção nas comunidades".

A partir dos contatos interétnicos, o ensino profissionalizante sempre esteve presente na história do povo indígena macuxi em Roraima. No século XX, passando pelos cursos promovidos pelo SPI que estavam relacionados às práticas de agropecuária na Fazenda São Marcos (curtir couro, confeccionar selas para montaria e trabalhos de marcenaria), que tinham o intuito de formar mão de obra para as fazendas.

As missões religiosas católicas, sendo beneditinas ou da ordem Consolata, atuaram na Missão Católica do Surumu ofertando cursos profissionalizantes. Posteriormente, sob a orientação da ordem Consolata, criou-se um centro de formação de lideranças indígenas. Em 1972, formaram a primeira turma de professores/as indígenas que lecionariam no ensino fundamental I e, em 1975, a turma que lecionaria no fundamental II concluiu seus estudos. Assim, começava a substituição dos professores não indígenas nas escolas indígenas (REPETTO, 2006, p. 8 e p. 81).

Nas entrevistas, notei certo desconforto a respeito de práticas culturais como as danças ou ensino de língua macuxi ou wapichana, muitas vezes por serem esses/essas estudantes de religiões cristãs e por esses pais já não falarem a língua originária e terem pouco contato com as referências culturais indígenas. Essas práticas, estimuladas nas escolas indígenas, parecem ser desnecessárias para alguns familiares e alunos/as indígenas. Muitos as interpretam como uma forma de preservar algo que não lhes pertence mais ou, em alguns casos, algo com que não possuem afinidade.

Um estudante comentou sobre seus motivos para não gostar muito de aprender a língua de seus ancestrais: 
E outra porque tem muito preconceito, tipo. Tipo a gente mesmo tem preconceito com a gente mesmo, porque a gente ouve os brancos falando mal da gente; aí a gente vai criando preconceito com a gente mesmo. Aí não tem interesse da gente aprender a nossa língua materna. Aí é por isso, mas a gente acha chato demais. Até que um certo tempo (eu) tava aprendendo a falar. Falar, não: ler. ${ }^{92}$

Uma estudante macuxi que mora na Vila Brasil explicou suas relações com a cultura indígena: "Até porque, mesmo... mesmo eu nascendo indígena, eu nunca tive contato com coisas que realmente eram dos indígenas. Não, porque tipo, eu não convivi com isso (danças, língua), então eu acho que eu não tenho muita afinidade, assim, com as coisas". ${ }^{93}$

Ela estudou na Escola Estadual Ovídio Dias (Vila Brasil), que não é uma escola indígena, e descreveu a tentativa fracassada de implementar o ensino de línguas nessa instituição:

Teve um tempo que colocaram, mas acho que só foi por um momento, não costumavam frequentar muito. Aí, como muitas pessoas não ligavam muito, não era obrigatório de assistir aula. Acho que foi na $7^{\mathrm{a}}$ série, o estudo de línguas. Acho que foi só uns dois meses, aí ninguém se interessava, aí tiraram. ${ }^{94}$

O diretor da Escola Estadual José Marcolino (Contão) ${ }^{95}$ salientou que houve dificuldade para a comunidade aceitar o ensino de língua macuxi ou wapichana, instituído em 2013. Os pais, que não consideravam importante esse tipo de aprendizagem para os/as alunos/as, queriam que o currículo ficasse restrito ao ensino médio e que não incluísse conteúdos voltados para as práticas culturais tradicionais. Após um longo debate, foram aceitos conteúdos voltados para o universo indígena.

A gestora da Escola Estadual Tuxaua Manoel Horácio, da comunidade do Guariba, descreveu como ocorriam essas atividades voltadas para a cultura indígena em sua unidade escolar, citando o trabalho com "temas contextuais":

Cada bimestre a gente trabalha com um tema diferente, às vezes voltado à saúde, à educação, ao meio ambiente, e dentro desses temas a gente tenta o máximo possível trazer pra dentro da realidade, trabalhar nos temas contextuais a realidade. Porque, querendo ou não, a gente tem que trabalhar os conteúdos, né?... E, dentro dos temas contextuais, porque a gente não tem como sair muito do conteúdo. Então, dentro do conteúdo, com os temas contextuais, a gente trabalha, a gente volta mais pra realidade, a realidade mesmo local. Por exemplo, a gente teve uma de educação, e eu trabalhei com os alunos a questão escolar indígena diferenciada, para eles entenderem o que eles conhecerem a luta, como foi que chegou a gente ter esse direito à educação escolar indígena diferenciada. Então, tipo, a gente procura trabalhar esses temas, voltado à realidade, dentro dos temas contextuais. ${ }^{96}$

92 Entrevista ao autor, mar. 2018.

93 Entrevista ao autor, mar. 2018.

94 Entrevista ao autor, mar. 2018.

95 Entrevista ao autor, mar. 2020.

96 Entrevista ao autor, mar. 2019. 
O fato de as escolas onde a maioria dos/as entrevistados/as estudou no ensino fundamental I e II serem indígenas, e manterem o ensino da língua materna, permitiu que esses estudantes tivessem um mínimo de contato com suas origens. Essas escolas, sendo indígenas, com professores macuxi ou wapichana, oferecendo ensino da língua materna e mantendo um momento cultural às sextas-feiras, com atividades como danças e outras práticas culturais, contribuem para que ainda se mantenha na memória dos/as entrevistados/as suas referências com a etnia à qual pertencem.

Repetto (2006, p. 63) constatou que em Roraima são faladas 14 línguas indígenas. Entretanto, foram notadas diferenças entre povos na relação com a língua. No caso dos Macuxi, a forte ocorrência não indígena em suas terras desde o século XVII, ocasionada por fazendas, garimpos e missões religiosas, tendo posteriormente a presença do Exército, escolas e outras instituições estatais, fortaleceu a língua portuguesa em detrimento das línguas originárias. Todavia, os Macuxi que estavam mais distantes da capital em regiões de difícil acesso mantiveram o uso cotidiano de sua língua materna.

A maioria dos Macuxi tem no português sua língua de alfabetização e sua língua materna acaba aparecendo como uma segunda língua. Como figura nos relatos, o preconceito com a língua indígena, a ausência dessa língua nas famílias - que, como instrumento de defesa, foram deixando de utilizá-la, pois eram vítimas de chacota e humilhações pelos não indígenas levaram a restringi-la aos mais idosos das comunidades. As pessoas mais jovens, principalmente as que residem em terras indígenas demarcadas em ilhas, praticamente desconhecem a língua originária.

Esse processo de restauração de práticas culturais ancestrais tem sofrido resistência, como atestaram os relatos dos/as estudantes macuxi. Repetto (2006, p. 64-65) aponta algumas possibilidades de estímulo a uma mudança nessa situação. Ele relata a utilização das línguas indígenas nos processos seletivos do Instituto Insikiran para o curso de licenciatura intercultural e nos concursos estaduais para contratação de professores/as indígenas, como o que ocorreu em 2002, cuja segunda fase era específica para indígenas e pedia a tradução do português de palavras e frases na língua do candidato/a.

Nos anos finais ou iniciais, os/as estudantes disseram não terem se arrependido de estudar na instituição:

Vale a pena vir pra cá. Eu estou gostando, pelo tempo que eu estou aqui. Minha mãe sempre falou que no tempo dela não tinha transporte, que para vir pra escola tinha que andar, que pelo menos agora eu estou (com) a facilidade de estar vindo pro Instituto, para na porta e traz, todos os dias. 
Foi bom, foi bom, agora. Pra mim, ter vindo pra cá foi bom demais, porque um grande avanço comigo. Depois que eu entrei aqui, vim ter a noção... ${ }^{97}$

Boa parte dos/as entrevistados/as afirmaram que suas expectativas para o futuro eram concluir o curso e ingressar no ensino superior. Poucos apresentaram desejo de retornar imediatamente às suas comunidades. Alegaram não ter oportunidade nestas, além de haver pouco incentivo para desenvolverem seus conhecimentos.

Uma jovem macuxi de 15 anos falou de seus planos quando terminasse o curso de Agropecuária:

como eu estava conversando com a minha mãe ontem, quando eu terminar eu não penso em voltar pra comunidade. Mesmo eu terminando o curso, vou fazer outro, porque esse é meu sonho. Mas eu entrei no Instituto porque eu estava precisando, realmente, aprender as coisas. (...) "Não, mas o meu sonho é fazer curso de medicina, e fazer mestrado e doutorado, que eu quero ser doutora." Aí, ela falou assim: "Mas isso é desde quando?", "Desde quando tu me pariu". Aí ela falou assim: "Mas tu não consegue, não". Porque ela fala que eu não posso ver muito sangue que eu fico passando mal. "Mas, mãe, a gente aprende coisas que vai dar pra eu fazer, sim." 98

Outro jovem, no $2^{\circ}$ ano de Agropecuária, mencionou seus projetos de futuro:

Até agora, eu estou... o professor falou que abriu um curso de Agronomia em Novo Paraíso, aí eu fiquei meio assim, como também vai ter... eu vi os meus tios indo se alistar e servir. Mas, se não der certo, eu fico no câmpus de Novo Paraíso. Eu, depois disso, eu pretendo sempre estar voltando, sempre ter algum local aqui, porque Boa Vista é muito turbulento. ${ }^{99}$

Um curso comumente citado foi o de Veterinária. Um estudante da Turma 126 em Agropecuária demonstrou interesse em ingressar nessa carreira em Boa Vista e, se não conseguisse, almejava voltar para a comunidade para ajudar em projetos:

No meu caso, eu pretendo fazer uma faculdade pra veterinário.

Acho que é porque (é) melhor, aí chega uns veterinários pra ver os cavalos, aí a gente fica vendo e fica admirado, né? A minha vontade é imensa em ser veterinário, mexer com animal.

Eu queria entrar mas vai ser meio difícil, porque eu não tenho pais que moram em Boa Vista, isso, porque eu só fui duas vezes em Boa Vista mesmo. ${ }^{100}$

97 Entrevista ao autor, mar. 2018.

98 Entrevista ao autor, mar. 2018.

99 Entrevista ao autor, mar. 2018.

100 Entrevista ao autor, mar. 2018. 
O tuxaua da comunidade do Barro, no Surumu, afirmou que a escola é muito importante para formar lideranças e professores. Lamentou, porém, a ausência desses jovens nas comunidades. ${ }^{101}$ Acrescentou que muitos continuavam seus estudos em universidades e não retornavam. Por outro lado, o tuxaua de Aningal, formado no curso de Agricultura do Instituto, afirmou que ainda estava na comunidade pela função que exercia ali. ${ }^{102}$

Um pai de aluno relatou ${ }^{103}$ que um de seus 13 filhos fez o curso de técnico em Agricultura, no Centro Indígena de Formação e Cultura Raposa Serra do Sol. Contudo, ele lamentou que o adolescente não tivesse obtido emprego na comunidade nem conseguido utilizar seus conhecimentos na região, por falta de recursos e apoio. Segundo ele, os alunos não se empregavam na comunidade mesmo com os cursos técnicos. Elencou, dentre os motivos, problemas internos da comunidade, falta de recursos para realizar o que se aprende e desinteresse dos adolescentes em trabalhar nas comunidades.

Uma egressa do curso de Agropecuária, da comunidade Guariba, comentou sobre suas dificuldades de trabalhar na sua comunidade:

Mas só que, aqui, eles têm o conhecimento deles, tipo, não aceita muito o que é técnico, eles preferem os conhecimentos deles mesmo.

No meu ponto de vista, melhoraria, o nosso conhecimento pra eles, mas só que... algumas coisas eles deixam a gente fazer, mas tem outras que eles acham, que eles discordam da gente. ${ }^{104}$

Um aluno macuxi do Barro, da Escola Estadual Indígena Tuxaua Silvestre Messias, que desejava cursar Medicina, falou de suas perspectivas de retornar à comunidade:

Acho meio difícil. No meu caso, porque quando a gente sai para fazer uma faculdade, eu acho que quer sair com um diploma para as portas se abrirem para a gente. Coisa que não tem aqui, eu acho que falta emprego ainda aqui. Essas coisas. Por conta disso, se tivesse alguma oportunidade de eu exercer alguma coisa na minha área que eu estudei, eu voltava sim. ${ }^{105}$

Nesses relatos vê-se que a ida ao CAM é marcada por uma expectativa de formação para um retorno que possibilite ajudar nos problemas das comunidades. Entretanto, no desenvolvimento da vida acadêmica, os/as estudantes vão vislumbrando a possibilidade de

101 Entrevista ao autor, fev. 2018.

102 Entrevista ao autor, fev. 2018.

103 Entrevista ao autor, fev. 2018.

104 Entrevista ao autor, mar. 2019.

105 Entrevista ao autor, mar. 2020. 
ampliarem seus estudos e, ao contrário das escolas indígenas das comunidades, o IFRR lhes fornece ferramentas para participar da disputa por vagas em instituições de ensino superior. Assim, o desafio se torna mais passível de ser enfrentado e o retorno vai sendo adiado ou retirado dos planos desses/as jovens.

O encontro intenso com o universo não indígena, vivido na permanência no CAM, diminui o já pouco interesse pelas práticas culturais originárias desses estudantes e acentua a desvinculação crescente de suas comunidades. A necessidade de uma discussão sobre essa situação com os/as estudantes, uma sensibilização quanto à importância da relação com a comunidade e o incentivo a ações locais poderiam estimular uma reflexão mais ampla sobre a possibilidade de se manterem em suas regiões de origem.

Mesmo com toda a satisfação apresentada pelos/as estudantes e a admiração pela instituição, foram observados alguns desagrados, restritos a três situações específicas do CAM. A primeira, abordada anteriormente, é a adaptação à estrutura curricular do Instituto. A quantidade de disciplinas diárias é muito grande e, como ainda não há um projeto de integração, somente uma parte dos/as professores/as propõe um trabalho com colegas com quem mantêm alguma afinidade. Além disso, os projetos de pesquisa e extensão normalmente são organizados somente por docentes, que inserem os/as alunos. Estes/as também alegaram dificuldades nas disciplinas de Química, Física e Matemática. Tampouco há aulas de língua materna e de cultura ou arte indígena no currículo, e os cursos de extensão oferecidos pelo CAM com elementos da cultura indígena como danças e músicas ainda são incipientes.

Houve alunos/as que relataram tais dificuldades nas disciplinas e no cotidiano do CAM:

Eu tive dificuldade, um monte de gente eu vi que teve dificuldade. A minha dificuldade foi em Matemática. Porque lá (Contão), a gente estudava o $3^{\circ}$ ano e a gente ficou quase um ano sem professor lá de Matemática. Aí, para não atrasar a gente aqui, a gente vem aqui estudar de manhã. Só vindo de manhã pra não atrasar.

A matéria que eu tive mais dificuldade foi Física. Muitos cálculos e, como a gente não teve no Contão... Que, no $1^{\circ}$ ano, até que eu levei bastante, assim, foi legal. Mas, na metade do ano, foi ficando mais pesados os cálculos. Mas eu consegui um pouco pegar. ${ }^{106}$

Uma Macuxi que está no segundo ano do técnico em Agropecuária descreveu suas dificuldades:

Primeiro, quando eu cheguei aqui, foi difícil porque é muito sono e é muito cansativo, acostumada a só estudar em um período, e chegar aqui que são dois. Assim, pra me adaptar, foi um mês, até hoje eu não posso dizer que eu conseguir me adaptar, porque eu não consegui, às vezes eu ainda sinto sono ainda. Mas, eu acho que é normal, faz parte, né? 
Acho que pegar tudo o que professor passa, ao longo do dia, não é só um professor que passa coisa, são quatro, cinco professores, assim...

Muita matéria, assim, é uma atrás da outra, tem o intervalo meio dia, mas o almoço. Eu acho muito cansativo e a dificuldade de realmente, guardar aquele conteúdo. ${ }^{107}$

Uma Macuxi da comunidade Três Corações relatou sua angústia e dificuldades em acompanhar os conteúdos:

Só Matemática, Física e Química, só essas que envolvem cálculo. Só porque Cálculo me confunde... Agora mesmo, sempre quando eu acordo, eu não sei, aí eu cheguei a falar com a minha irmã: "Eu não vou mais pra escola, que eu não aguento não", e ela: "Está muito bonito pra sua cara". "Todo semestre é igual, é bom que eu não volto." Aí, ela: "Negativo, pode ir". Aí, eu peguei e voltei de novo. Aí quando foi nas férias, eu pedi pra minha mãe me matricular lá em Boa Vista, que eu não queria voltar mais, não, e ela: "Quem disse, tu não quis entrar? Agora que tu vai aguentar até o $3^{\circ}$ ano". E eu: "Meu Deus do céu, eu estou preocupada". ${ }^{108}$

Em entrevista com o coordenador da Caes e com o enfermeiro, que compunham o quadro de funcionários dessa coordenação da instituição, foram mencionados casos de crises de ansiedade de alunos/as em períodos de avaliação. O receio de fracassar e as quantidades de atividades e provas escritas vinham levando os/as estudantes a sofrerem problemas de comportamento, depressão e envolvimento com drogas e, recentemente, houve um grupo de alunos e alunas que começaram a se cortar. Ainda que o cotidiano escolar não seja o único agravante dessas situações, colabora para tornar esse quadro mais delicado. Segundo os servidores da Caes:

As crises de ansiedade, que tem muito, a saudade de casa... e através dessas conversas a gente descobre outras coisas (...) A gente identificou que quando começa o início do ano está tranquilo, ainda está toda aquela empolgação. Aí eles começam com aquela rotina das aulas e, quando está próximo das provas... Porque as provas acumulam no mesmo período de final de abril, início de maio. Foi o período que a gente identificou que vai o pico de alunos com crise de ansiedade. Porque é muito trabalho, muita coisa para eles estudarem. Muita prova. Muita cobrança dos professores. O que a gente resolveu fazer? Quando chegar esse período, a gente intensifica as atividades para diminuir esses picos de ansiedade. ${ }^{109}$

A situação parece se complicar porque, muitas vezes, não se toma conhecimento da rotina desses/as estudantes, ou se menospreza esse cotidiano. Um dos estudantes do Guariba descreveu como era seu dia no Instituto e sua dificuldade em entregar as diversas atividades que são propostas em sala de aula, prejudicando sua média final.

107 Entrevista ao autor, mar. 2018

108 Entrevista ao autor, mar. 2018.

109 Entrevista ao autor, fev. 2020. 
A gente sai de lá (Guariba) 6 horas. Umas 5 h30 eu merendo lá em casa. Quando chega aqui, como a gente tem só almoço, compra alguma coisa pra comer. Todos os dias.

Chega lá (Guariba) quase umas 7 h30 (da noite). (...) Só que a estrada está ruim. Aí, a gente chega com dor de cabeça, meio cansado, aí a vontade é de banhar, comer e dormir.

Tive (dificuldades), só em relação a entregar atividade. ${ }^{110}$

Um jovem de 17 anos do Surumu retratou suas dificuldades com a língua portuguesa e como isso afetava a autoestima:

No meu caso é Português, porque, desde pequeno,... Não é que eu não me dava bem, eu queria aprender, mas só que eu não conseguia. No fundamental, os professores falavam que, se não gostava de ler, que ficava no cantinho com milho no joelho. Era desse jeito aí. Mandava tarefa pra casa, aí eu não fazia, porque o meu pai teve uma pancada na cabeça, perdeu a memória toda, só lembrava de Matemática e de algumas coisas. Aí não tinha ninguém pra me ajudar, e o mais velho era eu. Aí eu ia pro vizinho brincar, deixava de fazer as tarefas de Português. Agora, de Matemática não, tinha o meu pai que me ajudava. Aí eu deixava lá e ia embora. Dificuldade (é) mais com Português mesmo, de interpretar, essas coisas aí.

Agora, Matemática, não me considero muito bom, porque se eu soubesse Português eu acho que conseguia interpretar a questão de Matemática e resolver melhor. Eu tento aprender, lendo livro, mais livros, pegando dicionário, esses negócios. Aí um teste, até no $9^{\circ}$ ano, eu comecei a ler melhor, porque o professor Neides era um cara legal demais, me incentivou a aprender a ler livro. Eu não lia livro, eu lia todo gaguejando, só. Palavra por palavra. Aí ele me incentivou.

Aí tinha um... A mãe tinha pegado umas revistas na vizinha, levou lá pra casa pra gente ficar olhando as figurinhas. Aí eu comecei a ler em casa. Comecei a ler essas revistas, aí eu percebi que eu comecei a melhorar a ler, não gaguejava mais.

Aí comecei a me interessar mais, comecei a ler, ler, até que eu cheguei aqui. Cheguei com dificuldade. Daí, agora, quando saiu minhas notas de Português, é tudo 7. Mas eu prometi, falei pra professora, que nesse ano eu tiro uma nota 9. Não um 10, mas um 9 eu pretendo tirar. Falei pra ela que eu tenho dificuldade em Português.

Daí eu falava com as pessoas assim, tipo: falava uma palavra errada, aí começava a rir. Aí, eu só fico pensando na minha mente. Tem dias que eu fico ali na cama pensando, “por que eu não me esforcei mais no $1^{\circ}$ ano, no $2^{\circ}$ ano?". Porque aqui é bem puxado, e é de manhã e de tarde, aí não tem como. Chega no alojamento, o cara só quer saber de dormir e não consegue pegar no caderno; aí tem a limpeza do alojamento... Aí tem que dormir e acordar de manhã cedo pra vir, fica meio corrido. Quando tem um tempinho, eu vou lendo um livrinho e tento aprender mais, porque eu posso ser burro, mas... Eu tenho dificuldade de aprender as coisas. ${ }^{111}$

Um egresso do Guariba, de 19 anos, apresentou suas dificuldades quando estava estudando no CAM:

Tive dificuldades, sim, porque é puxado demais, e eu não estava acostumado. E aqui eu só estudava um período. Ir e vir, aí fica cansativo, também. Tinha que acordar cedo, e chegava umas 7 h30 (da noite). Aí não dava tempo de fazer quase nada. Muito material pra estudar, e ter que acordar cedo pra pegar o ônibus, aí fica puxado.

Fiquei (de dependência) em Física, em matérias assim, que quase eu fiquei, mas essas, mesmo, de Física, Química, Matemática. ${ }^{112}$

110 Entrevista ao autor, mar. 2018.

111 Entrevista ao autor, fev. 2018

112 Entrevista ao autor, mar. 2019. 
As dificuldades nas disciplinas de exatas mencionadas provavelmente estavam associadas à ausência de professores dessas disciplinas nas comunidades indígenas, causando defasagem no conteúdo a ser exigido dos/as estudantes. Mesmo havendo aulas de nivelamento de Física e Português, não parecem ter sido suficientes para resolver as dificuldades dos/as jovens que chegam à instituição.

No XVI Encontro Pedagógico do IFRR/CAM, ocorrido nos dias 4 e 5 de fevereiro de 2020, com o tema "Reflexões e perspectivas para a educação profissional e tecnológica no IFRR/CAM", a efetiva implantação de um projeto integrado foi amplamente discutida pelo corpo docente e pela área pedagógica. Essas mudanças coincidiram com um grupo de docentes dedicados/as às demandas dos/as discentes indígenas e à necessidade de reformulação dos planos de curso da instituição. Poderiam levar a um currículo mais próximo da realidade dos/as alunos/as, a uma diminuição de disciplinas e uma redução desse conjunto de problemas que eles/as têm enfrentado.

O segundo motivo de queixas recorrentes nas entrevistas com estudantes indígenas diz respeito a preconceitos que sofreram. Entre 2014 e 2016, o câmpus recebeu quatro alunos da etnia ingarikó, oriundos da TI Raposa Serra do Sol, que não dominavam o português e que permaneceram alojados na instituição durante o curso. Colegas de alojamento relataram que eles eram constantemente vítimas de humilhações e brincadeiras preconceituosas de alunos não indígenas e indígenas. As sessões de deboche e brincadeiras ocorriam no período noturno, quando os estudantes iam dormir. De acordo com relato de um aluno alojado, ele e outros indígenas sofreram discriminações e afirmaram não haver denunciado por medo de serem mal interpretados pelos colegas, e por acreditarem que seria melhor eles mesmos resolverem a situação.

Eu já (sofri preconceito), tipo: você é o índio. Você é índio, caboclo. No alojamento, tinha uns que... Não, o que eu via mais lá no alojamento... Eles não chegaram a bulinar comigo. Porque eu tive acho que... Sei lá, nós fala na cara mesmo. "Que é isso", e tal. No meu caso, eu falo, e também eu não ligo para as pessoas que falam.

Eu deixo passar, tipo: se você ligar pra pessoa que está te bulinando, é pior. Aí que eles vão gostar, mesmo.

No alojamento foi rápido. Por causa do negócio do bullying, (eu) só tinha dó dos meninos ingarikó, (...) os quatro. Os Ingarikó, que os meninos enchiam o saco, mesmo.

Mas eles perturbavam demais, chamavam de "caboclim", e eles começavam a responder. Aí toda noite era o mesmo, quase um dia ia rolando pau lá.

Cheguei até uma vez a falar com [ele], ele chegou a chorar comigo, e me perguntar de "Como é que vocês conseguem aturar um negócio desse". Eu deixo passar. Mas depois, quando eu estou sozinho, vem tipo aquela angústia de uma pessoa estar zombando de mim. Aí eu começo a chorar. Mas eu também não ligo, não, deixo passar. É melhor deixar quieto do que revidar com eles, senão é pior. 
Outro estudante afirmou ter sido vítima de preconceito em uma escola em Boa Vista, em um período em que esteve estudando e morando na capital:

Aqui não, mas eu tive em Boa Vista. Era mais, assim... Eles bagunçavam, até hoje. Porque no dia que estava tendo apresentação, eu falei que vinha da escola estadual, a professora perguntou de onde eu vinha, aí todo mundo começou a gritar: "Cadê tua tribo? Cadê tua tribo?". Acredito que o pessoal faz preconceito, porque ainda pensa que a gente ainda é como antigamente. ${ }^{114}$

Uma jovem descreveu uma situação de discriminação na escola de sua comunidade, Três Corações:

Isso, lá onde eu estudava, que eu penso assim: o menino que andava comigo, chegou na secretaria, mesmo, ele xingou um colega que era indígena. Falou um monte de coisa. Eu falei assim: "Olha, eu não sei porque eu ando contigo, porque eu sou indígena, e eu não gosto disso". Aí ele ficou assim... Se sentiu, e eu falei para a professora que não ia andar mais com uma pessoa desse tipo. ${ }^{115}$

Muitos/as jovens declararam ter visto alguém sofrer preconceito, ou terem eles/as mesmos/as sofrido discriminação, mas não se importaram, porque isso não os afetava. Assim foi a fala de um estudante de 18 anos da região do Surumu:

Eu nunca tive, eu quase... Nem se eu tivesse, eu não ligo pra essas coisas, entendeu? Eu já sofri por trás, mas na cara, mesmo, não. Entendeu? Por causa que eu não ligo pra essas coisas. Uma coisa que a pessoa fala, eu não estou nem aí. Porque eu sou eu. ${ }^{116}$

Uma jovem da Vila Brasil disse ter presenciado discriminação com os/as colegas, mas não com ela:

\footnotetext{
Assim, se fizeram preconceito comigo, eu não me senti constrangida por aquilo. Eles falavam... Que eu sentisse, não. Mas se tivesse ou visse algumas pessoas falando pra outras. Eu vejo a pessoa com preconceito mais com relação a outras pessoas, mas, pra mim, eu não levei isso como preconceito.

Bastante, porque tem muitos, eu vi bastante gente falando.

Eles chamam de "caboclinho", acham que caboclinho é feio.
}

113 Entrevista ao autor, mar. 2018.

114 Entrevista ao autor, mar. 2018.

115 Entrevista ao autor, mar. 2018

116 Entrevista ao autor, fev. 2018. 
A gente vê, incomoda. Mas é a rotina aqui, tem muita gente assim. ${ }^{117}$

O estado de Roraima tem um histórico de conflitos entre os não indígenas e indígenas há tempos. As disputas fundiárias por áreas de mineração, e um discurso recorrente na mídia local, identificam os indígenas como um empecilho para o desenvolvimento da região (LEAL, 2008; REPETTO, 2008b, p. 19). A situação se acirrou ainda mais quando da homologação da TI Raposa Serra do Sol, que ocasionou a expulsão de rizicultores, garimpeiros e fazendeiros da terra indígena. Consequentemente, o preconceito contra os indígenas é algo perceptível a qualquer pessoa que visite o estado.

No retorno de uma visita a comunidades localizadas na TI Raposa Serra do Sol e do município do Uiramutã, pegando carona em um carro do próprio câmpus, pude testemunhar o diálogo entre dois servidores que classificavam os indígenas como os responsáveis pela dificuldade de desenvolvimento do estado, e ainda os identificavam como pessoas sujas e incapazes de administrar a quantidade de terras que receberam. Sendo assim, as questões ligadas à convivência entre não índios e indígenas ainda são marcadas por tensões, até mesmo dentro do CAM, onde essa perspectiva sobre os povos originários deveria ter sido suplantada. Todavia, em conversa com a diretora de ensino ${ }^{118}$, reafirmou-se que as iniciativas desenvolvidas pela gestão vinham tentando sensibilizar os membros da comunidade escolar e o entorno do câmpus para o respeito às diferenças culturais existentes na sociedade roraimense.

$\mathrm{O}$ fato de a diretora de ensino ser indígena e ter participado do movimento indígena demonstra um sinal de interesse do câmpus em tentar romper com a visão estereotipada e preconceituosa sobre os indígenas na região. O diretor-geral do CAM afirmou ter sido uma estratégia para aproximar a instituição das comunidades indígenas:

\footnotetext{
A gente tinha que analisar. Primeiro, que nós lidamos com um público $70 \%$ indígena. O que é que nós fizemos? Um interlocutor... Apesar de que eu sou uma pessoa, hoje, que eu tenho uma aderência muito grande nas comunidades. Mas eu não tenho uma bagagem que (para) ela já vem de muitos anos, de trabalhar com indígenas: ela foi liderança indígena. O próprio MEC, de vez em quando, convida ela pra participar de discussão. Não está agora, mas, nos governos anteriores, a (diretora de ensino) viajava quase uma vez, duas vezes por ano, três, para ir para Brasília. Eu tinha que liberar, para ela ir lá fazer discussão. Então, ela sentava na mesa. Então ela foi uma questão técnica, nem foi questão de ser amigo, foi uma questão técnica de eu ter uma diretora que trabalha com a população, e que se entende e discute os problemas dessas comunidades há muitos anos. ${ }^{119}$
}

117 Entrevista ao autor, mar. 2018.

118 Entrevista ao autor, fev. 2020.

119 Entrevista ao autor, fev. 2018. 
Por fim, o terceiro motivo frequente de queixas dos alunos diz respeito ao alojamento. Ali, os/as estudantes relatam sofrer pequenos furtos e humilhações, e reclamam de falta de respeito às regras estabelecidas pela instituição. Um deles, que estava no $3^{\circ}$ ano, alegou falta de material de limpeza. Eles devem realizar o procedimento à noite. Por conta disso, não conseguem ter tempo para estudar, pois concluem as aulas às $17 \mathrm{~h} 45$ e jantam às 18h00. Depois têm de limpar o alojamento e passar por uma chamada às $21 \mathrm{~h} 00$ para, em seguida, dormirem. Segundo ele, os outros jovens não dormem no horário estipulado e, como devem acordar cedo para começar as aulas às $7 \mathrm{~h} 30$, sentem sono ao longo do dia.

Em virtude dessa situação, ele relatou dificuldade em acompanhar os conteúdos de disciplinas como Matemática, Física, Química e Português:

Cansado, não consegui dormir. Pra fazer limpeza é a maior frescura. E quando não faz, porque só tem dois rodos e duas vassouras! Enquanto um tá fazendo a limpeza do salão social e da área externa, e nós estamos precisando pra fazer a limpeza do banheiro, aí dá o horário pro professor fazer a chamada, lá, e a limpeza do banheiro não tá feita.

Aí não tem o suficiente pra fazer a limpeza bacana mesmo, tem só sabão em pó, só tira o sujo do chão.

Jogar alguma coisa no vaso, por exemplo, que faz as nossas necessidades lá, não tem um detergente, alguma coisa pra esfregar, não tem nada. É um prejuízo até para a nossa saúde mesmo.

No quarto, pra fazer limpeza, mesmo, é doideira. Tipo: na parte do banheiro, não dura nem 5 minutos e já está tudo sujo de novo, que é um entra-e-sai, de noite, os meninos são bem perturbados mesmo. Parecem que trocam o dia pela noite... Não dá pra estudar.

Só que os meninos falam demais, ficam agitados. Quando alguma coisa agita eles, aí começa a falar alto. Aí a gente não se concentra, acaba desistindo de estudar. ${ }^{120}$

Duas alunas da comunidade Aningal ${ }^{121}$ disseram dividir, no alojamento, um quarto com mais oito meninas de comunidades e etnias variadas. Em cada quarto, há um/a líder aluna/o responsável, para resolver problemas internos, como pequenos furtos, e questões como os atos de preconceito sofridos por elas/eles. Quando a/o líder não consegue resolver o problema, é acionado o responsável pelo alojamento, a saber, um servidor escolhido pelo diretor-geral do câmpus, que pode residir na instituição, em uma casa disponibilizada pelo CAM.

Elas disseram ter chorado muito com saudade do cotidiano da comunidade e de familiares, mas já estavam mais acostumadas. Em um poema, algumas alunas retrataram o cotidiano do alojamento feminino:

A vida no alojamento

Não é fácil como pensam,

Todo dia uma correria

Temos que cumprir as regras

120 Entrevista ao autor, fev. 2018.

121 Entrevista ao autor, fev. 2018. 


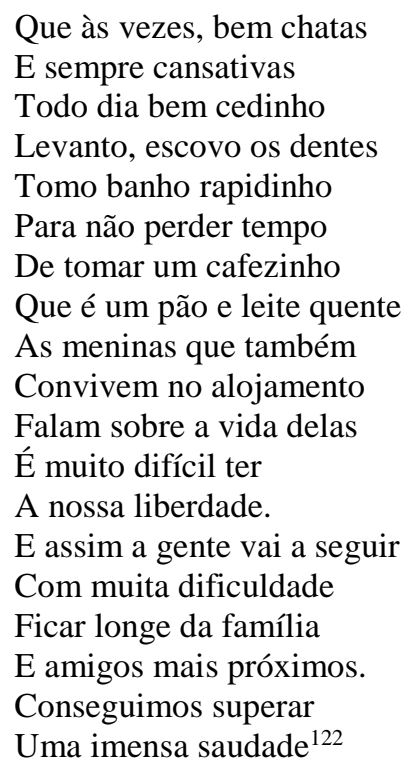

O alojamento tem sido alvo de ações da Caes, que veio trabalhando para reduzir as dificuldades com as quais os/as estudantes lidam. Desde 2018 têm ocorrido rodas de conversa entre os/as alunos/as alojados/as, sobre temas de seu interesse. O Caes tem promovido uma festa mensal com os/as aniversariantes do mês, bem como atividades extraclasse como aulas de yoga, capoeira e karatê, oferecidas por professores que voluntariamente se dispõem a colaborar para ajudá-los/as a superar o estresse do cotidiano escolar e da ausência das famílias. Entretanto, são ações espontâneas, diferentes de uma intervenção mais deliberada das coordenações responsáveis.

Percebe-se o esforço desses/as jovens em se adaptar a uma nova situação de aprendizagem, diversa daquela vivenciada em suas comunidades. No entanto, eles/as se sujeitam à distância de suas famílias, a tensões com alunos/as não indígenas e à dificuldade de adaptação por acreditarem que estão em uma instituição que lhes poderá abrir portas para um emprego ou para o acesso à universidade.

Essas e esses estudantes estão diariamente sob uma tensão para cumprir as determinações e orientações do cotidiano escolar e adaptar-se rapidamente à realidade do CAM para corresponder aos respectivos anseios de seus familiares, comunidades e da própria instituição. Contudo, a convivência nem sempre é respeitosa. A instituição procura adequar-se à complexidade cultural e social que a região requer, porém, sem responder à necessidade de dialogar com os/as discentes, lideranças indígenas, familiares e entorno do CAM, dificilmente atingiria esse objetivo. 


\section{CONCLUSÃO}

Quando iniciei esta pesquisa, eu havia colocado o problema da seguinte forma: Quais as motivações que atraem estudantes macuxi ao Câmpus Amajari do Instituto Federal de Roraima para cursarem ensino médio técnico profissionalizante em Agropecuária e Aquicultura em regime integrado e de alternância? Durante a pesquisa, também se avultou minha curiosidade a respeito das perspectivas que os/as estudantes traziam sobre a educação escolar que estavam recebendo. Resolvi então fazer uma reformulação, estabelecendo duas perguntas: Por que os/as estudantes macuxi se deslocam ao Câmpus Amajari do IFRR e o que buscam nessa instituição?

Minha primeira hipótese quanto à pergunta sobre a motivação para a vinda dos/as estudantes macuxi ao IFRR Câmpus Amajari foi a da necessidade de melhorar as condições de sobrevivência nas aldeias ou comunidades macuxi, o que seria proporcionado por conhecimentos ligados ao desenvolvimento das condições de manejo da agricultura, pecuária ou aquicultura. Passei a considerar essa hipótese pouco plausível após ter conversado com lideranças indígenas de algumas comunidades às quais os/as estudantes pertenciam, bem como com gestores/as de escolas indígenas, servidores/as, estudantes do CAM, egressos/as e discentes macuxi de outras escolas de ensino médio indígena de Roraima. Também examinei pesquisas sobre a história dos povos originários da região, a educação escolar indígena diferenciada possível em Roraima e percepções da juventude macuxi.

A hipótese que me pareceu mais forte foi a de que o motivo que trazia esses/as estudantes era, principalmente, o desejo dos familiares e lideranças de que os/as jovens, após adquirirem uma formação técnica profissionalizante, retornassem às suas comunidades para auxiliarem em futuros projetos agropecuários ou de piscicultura. Mas os/as estudantes também estariam atribuindo outros objetivos à experiência no CAM, que poderiam não coincidir com o desejo de seus e suas responsáveis.

Certamente é possível entender que a atual necessidade das comunidades indígenas de Roraima de desenvolverem atividades agropecuárias e projetos de piscicultura facilitados por técnicas mais apropriadas, assim como a premência de gerar ocupação para a juventude localmente ou em contextos urbanos, motivaram as lideranças e familiares dos/as estudantes macuxi a os/as encaminharem ao câmpus. Entretanto esses/as jovens mostraram um entendimento diferente, não totalmente oposto ao das lideranças e familiares: buscam uma formação melhor que entendem não receber em suas comunidades. Assim, a hipótese referente 
aos motivos que atraem os/as jovens macuxi ao CAM se mostrou verdadeira, pois foi constatado que estão inicialmente condicionados/as às decisões de seus/suas responsáveis e, da mesma forma, evidenciou-se que, no decorrer da formação e do ambiente escolar, a maioria desses/as Macuxi é impulsionada a prosseguir em seus estudos. O que nos leva à segunda pergunta norteadora da pesquisa.

Tratava-se de saber o que buscam os/as Macuxi no CAM. A hipótese que levantei foi a de que a maioria discente procurava uma escolarização que a colocasse em melhores condições para a disputa de vagas nos cursos superiores disponíveis em Boa Vista e em outros municípios do estado.

As informações que sistematizei permitiram constatar que os/as discentes acreditavam ser as condições de aprendizagem do Câmpus Amajari melhores que as das escolas de suas respectivas comunidades, por não se depararem com a falta de professores/as, por disporem de uma grade curricular com um número maior de disciplinas e porque os/as docentes do CAM eram vistos/as como tendo uma formação melhor que os/as professores/as indígenas das escolas que haviam frequentado no ensino fundamental.

Apresentando essa visão negativa a respeito de suas escolas e desejando ingressar em cursos superiores, acabavam considerando o Câmpus Amajari uma instituição que os/as ajudaria a atingir seu objetivo de formação superior. Mas conquistar esse objetivo e retornar às comunidades indígenas após a formação universitária talvez se diferencie dos desejos e anseios de seus responsáveis e de suas lideranças.

É preciso levar em conta que o câmpus do Instituto Federal de Roraima na cidade de Amajari (IFRR/CAM), no extremo norte brasileiro, se constituiu também pela influência de movimentos indígenas atuantes, dos quais se desdobrou a organização dos professores indígenas, que, desde a década de 1980, luta por uma educação escolar indígena diferenciada, mantendo uma quantidade significativa de escolas de ensino médio em suas comunidades. Todavia, muitos/as estudantes indígenas têm se deslocado para o CAM, chegando a somar mais da metade dos seus discentes.

As informações colhidas na pesquisa e reportadas aqui mostram que o interesse dos/as jovens macuxi no Instituto Federal advém da precariedade física de suas escolas de origem e da incompreensão e rejeição ao projeto de escola indígena diferenciada proposto e oferecido pelo governo estadual de Roraima às comunidades, além da sentida necessidade de cursos técnicos que viabilizem a ocupação profissional dessa juventude dentro ou fora das comunidades indígenas. Assim, apresentei a situação das escolas públicas em Roraima, da qual faz parte a maioria das escolas indígenas diferenciadas de ensino médio. Os relatos dos/as 
estudantes retrataram também uma indisposição para com a proposta de valorização da cultura originária, ora pela matriz religiosa de estudantes e familiares - como no caso da comunidade do Contão, onde práticas culturais macuxi são proibidas pela igreja protestante local -, ora pelo distanciamento cultural desses estudantes em relação às práticas tradicionais.

Tais aspectos se somam à falta de professores/as indígenas nas diversas escolas das regiões de onde vêm os/as estudantes, bem como às constantes suspensões de aulas causadas por razões variadas, notadas pelos/as estudantes, que, por sua vez, se sentem desestimulados a permanecer nessas escolas. Atraídos/as pelas condições físicas do CAM e pelos cursos técnicos oferecidos nas áreas de Agropecuária e de Aquicultura, eles/as abrem mão de frequentar escolas indígenas diferenciadas para estar em uma instituição de ensino não indígena onde, a despeito de todos os elogios que tecem, enfrentam problemas de adaptação ao ensino em tempo integral, preconceitos e dificuldades de moradia no alojamento.

Entendo que a chegada desses/as estudantes está relacionada inicialmente a um anseio dos familiares, de amigos/as e de algumas lideranças indígenas, que almejam o retorno da geração jovem às suas comunidades para suprir demandas das atividades econômicas locais. Há estudantes que chegam com o desejo de retornarem às comunidades para ajudarem familiares ou para serem inseridos/as em projetos comunitários; no entanto, a maioria vê no CAM uma estratégia para ingressar no ensino superior.

Reconhecendo as dificuldades de suas escolas indígenas, passam a interpretar o IFRR como local de acesso a um "ensino forte" que lhes prepare para disputar uma vaga na universidade em condições mais justas. Entretanto, não expressaram o entendimento de que os problemas de suas unidades escolares, se não resolvidos, continuarão a distanciá-los/as das comunidades. Eles/as ainda as descreveram positivamente, em geral como ambientes de convivência com a natureza e de práticas agrícolas que compartilham com seus familiares em seus lugares de origem. Porém, quando questionados/as sobre a permanência em suas regiões, demonstraram desinteresse, destacando a ausência de oportunidades laborais e de lazer.

Portanto, a hipótese levantada para a outra questão da pesquisa também se confirmou, tendo-se explicitado o ensino superior como um projeto de futuro desses/as estudantes do CAM. Ali eles/as são estimulados/as a continuar estudando para ter um "futuro melhor", e se motivam para ingressar em um curso superior no próprio câmpus ou em instituições da capital.

Desde 2012, quando iniciou o curso integrado de Agropecuária, o CAM formou um total de 245 estudantes indígenas, segundo dados fornecidos pelo Cores. O destino desses/as diplomados/as, porém, é cada vez mais incerto, porque muitos/as não conseguiram trabalho na área cursada, nem em suas comunidades e tampouco na capital. Uma parte se encaminhou para 
cursos superiores e, recentemente, outros/as têm optado por cursar o superior em Aquicultura ofertado pelo CAM. Como registrado anteriormente, de 60 alunos/as do superior em Aquicultura, 16 eram oriundos/as dos cursos do ensino técnico integrado da instituição.

O câmpus dispõe de um corpo docente e técnico qualificado e continua a fornecer capacitação para suas/seus servidoras/es. Entretanto, não tem disseminada uma concepção educativa que valorize a diversidade cultural interna de forma mais consistente e que problematize a tensão existente entre não indígenas e indígenas.

Comumente, os custos da escolha pelo ensino médio do IFRR em Amajari em detrimento das escolas indígenas são demasiadamente altos, pois estudantes com dificuldade de acompanhar um ritmo acelerado de tarefas passam por estresse excessivo e frustrações. Sofrem discriminação e têm dificuldade de adaptação à rotina da instituição, que, a despeito do esforço de alguns e algumas servidoras, ainda não dispõe de práticas suficientemente atentas aos anseios e apuros vivenciados por estudantes macuxi.

Por sua vez, a ida à capital ou a outro centro urbano local também não garante sucesso profissional ou pessoal a esses/as estudantes macuxi. Com algumas exceções, tornam-se jovens subempregados/as, levados/as a viver em áreas periféricas, com limitação de serviços públicos, sofrendo variados tipos de preconceitos. Além de não conseguirem se manter, somam-se ao grande número de venezuelanos/as expostos/as a condições sanitárias e habitacionais inadequadas. Esses perigos da cidade sem o apoio das famílias ou das organizações indígenas podem acarretar irreversíveis situações de degradação.

A angústia de ficar na comunidade e o plano de seguir para a cidade para tentar novas oportunidades preocupam lideranças, pais e mães desses/as estudantes. De fato, as comunidades são afetadas pela proximidade com a sociedade envolvente, tendo suas áreas de caça, pesca e agricultura prejudicadas, opostas à abundância de outrora. Consequentemente, apresentam um cotidiano marcado por falta de emprego e por penúria, ao passo que a juventude é cada vez mais influenciada pelas mídias. Além disso, a proximidade de um passado colonial e explorador também leva pais, mães e responsáveis a considerarem a educação como um caminho para uma vida mais segura e confortável.

No entanto, as comunidades, conforme detalhei, não têm atendido às demandas desses/as estudantes por uma escola mais próxima de seus interesses. A visão negativa sobre as escolas locais se soma à busca de opções como o CAM. O quadro se acentua com a falta de investimento público nessas regiões e de formação adequada do professorado indígena, em um número que possa suprir satisfatoriamente as necessidades de quadros docentes. Desgasta-se, assim, o projeto de uma escolarização indígena diferenciada. 
Olhando para as práticas de valorização cultural desenvolvidas nessas unidades escolares, detectei a falta de interesse de jovens indígenas por cantos, danças e aprendizado da língua originária, o que possivelmente demanda uma revisão acerca dos meios com os quais os traços culturais estão sendo praticados. Famílias que não compartilham dessas marcas culturais tendem a desestimular o aprendizado desses aspectos, e o receio de perdê-los ou esquecê-los ainda paira sobre os mais velhos e as lideranças dessas regiões.

Refletir sobre a importância dessas características abertamente com a juventude macuxi, valorizar a luta pela escola indígena diferenciada como um modo de garantir uma vida melhor nas comunidades, lutar pela implantação de universidades nesses territórios e permitir que esses/as jovens tenham seus interesses e opções pessoais compreendidas e discutidas podem compor o caminho a trilhar para a realização do seu direito à educação. 


\section{REFERÊNCIAS ${ }^{123}$}

ABBONIZIO, A. C. de O. Educação escolar indígena como inovação educacional: a escola e as aspirações do futuro das comunidades. 2013. Tese (Doutorado em Educação) Faculdade de Educação, Universidade de São Paulo, São Paulo, 2013. 133 p.

ALBUQUERQUE, M. A. dos S. O regime imagético Pankararu: tradução intercultural na cidade de São Paulo. 2011. Tese (Doutorado em Antropologia Social) - Universidade Federal de Santa Catarina, Florianópolis, 2011. 428 p. Disponível em: https://repositorio.ufsc.br/xmlui/handle/ 123456789/95460. Acesso em: 9 set. 2015.

ALBUQUERQUE, M. A. dos S.; NAKASHIMA, E. Y. Consenso e dissenso: os Pankararu e a educação intercultural na cidade de São Paulo. In: TASSINARI, A. M.; GRANDO, B. S.; ALBUQUERQUE, M. A. dos S. (orgs.). Educação indígena: reflexões sobre noções nativas de infância, aprendizagem e escolarização. Florianópolis: UFSC, 2012. $304 \mathrm{p}$.

ALONSO, V. F. Roraima: movimento indígena, demarcação de terra e conflito social. 2013. Dissertação (Mestrado em Ciências Sociais) - Pontifícia Universidade Católica de São Paulo, São Paulo, 2013. 92 p.

ANDRADE, E. da S. Conhecimento indígena e o processo de formação social do jovem no contexto da Comunidade Maruwai, Terra Indígena São Marcos. 2016.

Dissertação (Mestrado em Sociedade e Fronteiras) - Universidade Federal de Roraima, Boa Vista, 2016. 126 p.

ANDRADE, J. A. A. D. Indigenização da cidade: etnografia dos circuitos Sateré-Mawé em Manaus-AM e arredores. 2012. Dissertação (Mestrado) - Faculdade de Filosofia, Letras e Ciências Humanas, Universidade de São Paulo, São Paulo, 2012. 152 f.

ANDRELLO, G. Iauaretê: transformações sociais e cotidiano no rio Uaupés (Alto Rio Negro, Amazonas). 2004. Tese (Doutorado em Ciências Sociais) - Instituto de Filosofia e Ciências Humanas, Universidade Estadual de Campinas, Campinas, 2004. 239 p.

Cidade do índio. São Paulo: Ed. Unesp / ISA; Rio de Janeiro: Nuti, 2006.

ARAÚJO, M. Do corpo à alma: missionários da Consolata e índios macuxi em Roraima. São Paulo: Fapesp / Associação Editorial Humanitas, 2006. 248 p.

ASSIS, E. C. de. Escola indígena, uma “frente ideológica"? 1981. Dissertação (Mestrado em Antropologia Social) - Universidade de Brasília, Brasília, 1981. 204 p.

BARROS, G. S. A educação profissional em regime de alternância na comunidade indígena do Guariba, Roraima. Dissertação (Mestrado em Educação Agrícola) Universidade Federal Rural do Rio de Janeiro, Seropédica, 2013. 
BARTH, F. O guru, o iniciador e outras variações antropológicas. Tradução: John Cunha Comerford. Rio de Janeiro: Contra Capa Livraria, 2000.

BEGNAMI, J. B.; BURGHGRAVE, T. de. Posfácio de atualização. In: NOSELLA, Paolo. Educação no campo: origens da pedagogia da alternância no Brasil. Vitória: Edufes, 2012.

BERNAL, R. J. Índios urbanos: processos de reconformação social das identidades étnicas indígenas em Manaus. Manaus: Ufam, 2009. 334 p.

BEZERRA, F. A. Institutos Federais: inovações, contradições e ameaças em sua curta trajetória. In: ARAÚJO, A. C.; SILVA, C. N. Ensino médio integrado no Brasil: fundamentos, práticas e desafios. Brasília: IFB, 2017. p. 358-376.

BORTOLON, D. M. O. Terra indígena Araçá/Roraima: continuidades e transformações envolvendo coletividades Macuxi. 2014. Dissertação (Mestrado em Ambiente e Desenvolvimento) - Centro Universitário Univates, Lajeado, 2014.

BRASIL. Lei no 9.394, de 20 de dezembro de 1996. Estabelece as diretrizes e bases da educação nacional. Disponível em:

http://www.planalto.gov.br/ccivil_03/leis/19394.htm. Acesso em: 24 out. 2016.

Lei $\mathrm{n}^{\circ}$ 11.892, de 29 de dezembro de 2008. Institui a Rede Federal de Educação Profissional, Científica e Tecnológica, cria os Institutos Federais de Educação, Ciência e Tecnologia, e dá outras providências. Disponível em: http://www.planalto.gov.br/ccivil_03/_Ato2007-2010/2008/Lei/L11892.htm. Acesso em: 24 out. 2016.

Decreto $n^{0}$ 7.352, de 4 de novembro de 2010. Dispõe sobre a política de educação do campo e o Programa Nacional de Educação na Reforma Agrária PRONERA. Disponível em: http://portal.mec.gov.br/docman/marco-2012-pdf/101998-decreto-7352-de4-de-novembro-de-2010/file. Acesso em: 13 out. 2017.

BRAYNER, T. N. É terra indígena porque é sagrada: Santuário dos Pajés. 2013. Dissertação (Mestrado em Antropologia) - Universidade de Brasília, Brasília, 2013. $151 \mathrm{p}$.

CANTALUCE, M. F. P. Educação profissional e ensino médio: relação direta com a(s) juventude(s)? [S.1.]: [s.n.], 2012. Disponível em: https://silo.tips/download/educaaoprofissional-e-ensino-medio-relaao-direta-com-as-juventudess\#. Acesso em: 23 jun. 2018.

CAPACLA, M. V. O debate sobre a educação indígena no Brasil (1975-1995): resenhas de teses e livros. Brasília: Ministério da Educação e Desporto, 1995.

CAVALCANTI, R. A. S. Presente de branco, presente de grego?: escola e escrita em comunidades indígenas do Brasil Central. 1999. Dissertação (Mestrado em Antropologia Social) - Museu Nacional, Universidade Federal do Rio de Janeiro, Rio de Janeiro, 1999. 208 p.

CIAVATTA, M. O ensino integrado, a politecnia e a educação omnilateral: por que lutamos? Trabalho e Educação, Belo Horizonte, v. 23, n. 1, p. 187-205, jan./abr. 2014. 
CIAVATTA, M.; RAMOS, M. Ensino médio e educação profissional no Brasil: dualidade e fragmentação. Retratos da Escola, Brasília, v. 5, n. 8, p. 27-41, jan./jun. 2011. Disponível em: http://retratosdaescola.emnuvens.com.br/rde/article/view/45/42. Acesso em: 12 ago. 2020.

CICOUREL, A. Teoria e método em pesquisa de campo. In: GUIMARÃES, A. Z. Desvendando máscaras sociais. Rio de Janeiro: Jorge Zahar, 1975. p. 87-121.

COFFANI, M. C. R. da S.; GOMES, C. F. Estudos sobre juventudes: implicadores teóricos e metodológicos sobre culturas juvenis e ensino médio. Revista CAMINE: Caminhos da Educação, Franca, v. 10, n. 2, p. 3-26, 2018.

COHN, C. Culturas em transformação: os índios e a civilização. São Paulo em Perspectiva, São Paulo, v. 15, n. 2, p. 36-42, 2001.

Educação escolar indígena: para uma discussão de cultura, criança e cidadania ativa. Perspectiva, Florianópolis, v. 23, n. 2, p. 485-515, jul./dez. 2005.

A cultura nas escolas indígenas. In: CUNHA, M. C. da; CESARINO, P. de N. (orgs.). Políticas culturais e povos indígenas. São Paulo: Editora Unesp, 2016. 518 p.

COMISSÃO PRÓ-ÍNDIO DE SÃO PAULO; CENTRO GASPAR GARCIA DE DIREITOS HUMANOS. A cidade como local de afirmação dos direitos indígenas. São Paulo: Comissão Pró-Índio de São Paulo / Centro Gaspar Garcia de Direitos Humanos, 2013. $112 \mathrm{p}$.

COSTA FILHO, B.; SANTOS, R. N. G. O despertar para o movimento indígena em Roraima nas décadas de 70 e 80: a luta pela autonomia política indígena e de seus ambientes ancestrais. In: VIEIRA, J. G. O Rio Branco se enche de história. 2. ed. Boa Vista: EDUFRR, 2016. p. 197-220.

CUNHA, C. M. Um estudo de fonologia da língua Makuxi (Karib): inter-relações das teorias fonológicas. 2004. Tese (Doutorado em Linguística) - Instituto de Estudos da Linguagem, Universidade Estadual de Campinas, Campinas, 2004. 191 p. Disponível em: http://www.repositorio.unicamp.br/handle/REPOSIP/268996. Acesso em: 12 ago. 2020.

CUNHA, L. O. P. A política indigenista no Brasil: as escolas mantidas pela Funai. 1990. Dissertação (Mestrado em Educação) - Universidade de Brasília, Brasília, 1990. 134 p.

CUNHA, M. C. da. Antropologia do Brasil: mito, história, etnicidade. 2. ed. São Paulo: Brasiliense, 1986. 173 p.

Cultura com aspas. São Paulo: Cosac Naify, 2009. 440 p.

. Políticas culturais e povos indígenas: uma introdução. In: CUNHA, M. A., CESARINO, P. de N. (orgs.). Políticas culturais e povos indígenas. São Paulo: Editora Unesp, 2016. 518 p.

CUNHA, V. P. da; SOLER, W. A.; OLIVARES, C. T.; FILHO, A. R. A reprodução do espaço urbano em Roraima: Uma análise sobre o impacto da implantação do Instituto Federal em Amajari-RR. In: JÚNIOR, S. S. T.; MOURÃO, G. M. N. (orgs.). Amajari: um olhar geográfico. Boa Vista: Editora da UFRR, 2015. 283 p. 
DAL BÓ, T. L. Construindo pontes: o ingresso de estudantes indígenas na UFSCar, uma discussão sobre "cultura" e conhecimento tradicional. Dissertação (Mestrado em Antropologia Social) - Universidade Federal de São Carlos, São Carlos, 2010. 106 p.

. A presença de estudantes indígenas nas universidades: entre ações afirmativas e modos de conhecer. Tese (Doutorado em Antropologia Social) - Universidade de São Paulo, São Paulo, 2018. 251 p.

DAUSTER, T. Um saber de fronteira: entre a antropologia e a educação. In: Antropologia e educação: um saber de fronteira. Rio de Janeiro: Forma \& Ação, 2007. p. 13-35.

DAYRELL, J. Escola como espaço sociocultural. In: DAYRELL, J. (org.). Múltiplos olhares sobre educação e cultura. 2. ed. Belo Horizonte: Ed. UFMG, 2001. p. 136-161.

DAYRELL, J.; CARRANO, P. Juventude e ensino médio: quem é este aluno que chega à escola. In: DAYRELL, J.; CARRANO, P.; MAIA, C. L. (orgs.). Juventude e ensino médio: sujeitos e currículos em diálogo. Belo Horizonte: Editora UFMG, 2014. 101$134 \mathrm{p}$.

DELEUZE, G. Diferença e repetição. Rio de Janeiro: Graal, 1988.

DICKEL, K. S. M. Experiências interculturais: estudantes kaingang numa escola não indígena. Dissertação (Mestrado em Educação) - Universidade Federal do Rio Grande do Sul, Porto Alegre, 2013.

DINIZ, E. S. Os índios Makuxi do Roraima: sua instalação na sociedade nacional. Tese (Doutorado em Antropologia) - Faculdade de Filosofia, Ciências e Letras, Marília, 1972. $190 \mathrm{p}$.

DOSSIÊ Raposa Serra do Sol: um projeto de vida para os povos indígenas da Amazônia e do Brasil. Terra Indígena Raposa Serra do Sol: [s. n.], 2017. Disponível em: http://apib.info/files/2017/10/Dossi\%C3\%AA-Raposa-Serra-do-Sol_LM2-FINAL.pdf. Acesso em: 4 mar. 2018.

FARAGE, N.; SANTILLI, P. Estado de sítio: territórios e identidades no Vale do Rio Branco. In: CUNHA, M. C. A história dos índios no Brasil. São Paulo: Companhia das Letras, 1992. p. 267-278.

FERNANDES, F. M. M. Do parixara ao forró, do forró ao "parixara": uma trajetória musical. 2015. Dissertação (Mestrado em Antropologia Social) - Universidade Federal de São Carlos, São Carlos, 2015. 168 p.

FERREIRA, E. F. F. Direito ao desenvolvimento das comunidades indígenas: o direito ao território interpretado pelo Supremo Tribunal Federal no julgamento da Terra Indígena Raposa Serra do Sol. Planeta Amazônia: Revista Internacional de Direito Ambiental e Políticas Públicas, Macapá, n. 7, p. 61-73, 2015. Disponível em: https://periodicos.unifap.br/index.php/planeta. Acesso em: 25 fev. 2019.

FERREIRA, M. K. L. Da origem dos homens à conquista da escrita: um estudo sobre povos indígenas e educação escolar no Brasil. 1992. Dissertação (Mestrado em Antropologia Social) - Faculdade de Filosofia, Letras e Ciências Humanas, Universidade de São Paulo, São Paulo, 1992. 227 p. 
FERRI, P. Achados ou perdidos? A imigração indígena em Boa Vista. Goiânia: MLAL, 1990. $134 \mathrm{p}$.

FONSECA, C. Quando cada caso NÃO é um caso: pesquisa etnográfica e educação. Revista Brasileira de Educação, n. 10, p. 58-78, jan./abr. 1999.

FREITAS, D. de B. A. P. Escolas Macuxi: identidades em construção. 2003. Tese (Doutorado) - Instituto de Estudos da Linguagem, Universidade Estadual de Campinas, Campinas, 2003. 234 p.

FREITAS, M. A. B. de. Educação escolar indígena: realidade e perspectiva em Roraima. Textos \& Debates, n. 9, p. 85-112, ago./dez. 2005.

Educação e direitos humanos: desafios da contemporaneidade. In: CARVALHO, F. A.; FONSECA, I. M., REPETTO, M. Educação, cidadania e interculturalidade no contexto da escola indígena de Roraima. Boa Vista: Editora Fondo Editorial Brasil / UFRR, 2007. p. 36-41.

Insikiran: da política indígena à institucionalização da educação superior. Tese (Doutorado em Sociedade e Cultura na Amazônia). Universidade Federal do Amazonas, Manaus, 2017. 263 p. Disponível em: https://tede.ufam.edu.br/handle/tede/5611. Acesso em: 25 fev. 2019.

FREITAS, M. A. B.; TORRES, I. C. O. O papel do movimento indígena no processo de escolarização do ensino superior na Amazônia. Olhares Amazônicos: Revista Científica do Núcleo de Pesquisas Eleitorais e Politicas da Amazônia, UFRR, v. 4, n. 1, p. 748-761, 2016.

FRIGOTTO, G.; CIAVATTA, M.; RAMOS, M. A política de educação profissional no Governo Lula: um período histórico controvertido. Educação e Sociedade, Campinas, v. 26, n. 92, p. 1087-1113, out./2005.

GALLOIS, D. T. A escola como problema: algumas posições. In: CESARINO, P. de N.; CUNHA, M. C. (orgs.). Políticas culturais e povos indígenas. São Paulo: Editora Unesp, 2016.

GHANEM, E. Educação escolar e democracia no Brasil. Belo Horizonte: Autêntica; São Paulo: Ação Educativa, 2004. 219 p.

. Que avaliação vale na educação escolar? In: LUCE, B.; MEDEIROS, I. L. P. Gestão escolar democrática: concepções e vivências. Porto Alegre: Editora UFRGS, 2006.

. Educação formal e não-formal: do sistema escolar ao sistema educacional. In: ARANTES, V. (org.). Educação formal e não-formal. São Paulo: Summus, 2008.

. As inovações da escola tuyuka: superando a educação colonialista. In:

MILITÃO, A. N.; SANTANA, M. S. R. (orgs.). Intersecções entre pesquisas/pesquisadores experientes e pesquisas/ pesquisadores iniciantes no campo educacional. São Carlos: Pedro \& João Editores, 2016. p. 203-244.

GHANEM, E.; ABBONIZIO, A. A escola indígena e as aspirações de futuro das comunidades. Tellus, ano 12, n. 23, jul./dez./2012. 
GOBBI, I. A temática indígena e a diversidade cultural nos livros didáticos de história: uma análise dos livros recomendados pelo Programa Nacional do Livro Didático. 2006. Dissertação (Mestrado em Ciências Sociais) - Universidade Federal de São Carlos, São Carlos, 2006.

GROPPO, L. A. Dialética das juventudes modernas e contemporâneas. Revista de Educação do Cogeime, Belo Horizonte, ano 13, n. 25, p. 9-22, dez. 2004.

GRUPIONI, L. D. B. Imagens contraditórias e fragmentadas: sobre o lugar dos índios nos livros didáticos. Revista Brasileira de Estudos Pedagógicos, Brasília, v. 77, n. 186, p. 409-437, maio/ago. 1996.

A educação indígena na academia: inventário comentado de dissertações e teses sobre educação escolar indígena no Brasil (1978-2002). Em Aberto, Brasília, v. 20, n. 76, p. 197-238, fev. 2003.

Olhar longe, porque o futuro é longe: cultura, escola e professores indígenas no Brasil. 2008. Tese (Doutorado em Antropologia Social) - Faculdade de Filosofia, Letras e Ciências Humanas, Universidade de São Paulo, São Paulo, 2008.

GUIMARÃES, L. M. de A.; FERREIRA JÚNIOR, A. Luchas políticas de las poblaciones indígenas en Roraima (Brasil) y la confrontación con la pandemia de COVID-19. Mundo Amazónico, v. 11, n. 2, 223-243. Disponível em: https://doi.org/10.15446/ma.v11n2.88715. Acesso em: 23 dez. 2020.

GUSMÃ̃, N. M. Por uma Antropologia da Educação no Brasil. Pro-Posições, Campinas, v. 21, n. 2 (62), p. 259-265, maio/ago. 2010.

IFRR. Regimento geral. Boa Vista: IFRR, 2015. Disponível em: https://www.ifrr.edu.br/acessoainformacao/rg/regimento-geral. Acesso em: 28 nov. 2019.

Plano estratégico institucional para a permanência e êxito dos estudantes do IFRR Câmpus Amajari. Amajari: IFRR, 2016. 45 p.

Resolução n. 338/Conselho superior, de $1^{\circ}$ de fevereiro de 2018. Aprova a reformulação da organização didática do IFRR. Disponível em: https://www.ifrr.edu.br/acessoainformacao/participacao-social/conselhos-e-orgaoscolegiados/conselho-superior/resolucoes/resolucoes-consup-2018/resolucao-n-o-338conselho-superior. Acesso em: 28 nov. 2019.

INSTITUTO UNIBANCO. Panorama dos Territórios: Roraima. Observatório de Educação — Ensino Médio e Gestão. São Paulo: Instituto Unibanco, 2019. 43 p. Disponível em: https://observatoriodeeducacao.institutounibanco.org.br/api/assets/833d30a4-61b44ba4-83c2-afc3d26af36c/. Acesso em: 12 ago. 2020.

JUNIOR, R. de L. R. Ensino médio integrado: correlação de força de uma escola em disputa. In: ARAÚJO, A. C.; SILVA, C. N. N. da (orgs.). Ensino médio integrado no Brasil: fundamentos, práticas e desafios. Brasília: Ed. IFB, 2017. 569 p.

KAHN, M. Educação indígena. Cadernos de Pesquisa, n. 7, p. 49-63, maio 1997. 
LASMAR, C. De volta ao Lago de Leite: gênero e transformações no Alto Rio Negro. Livro eletrônico. São Paulo: Editora Unesp, 2005. Não paginado.

LEVI, G.; SCHMITT, J.-C. Introdução. In: LEVI, G.; SCHMITT, J.-C. (orgs.). História dos jovens: da antiguidade à era moderna. Tradução: Claudio Marcondes; Nilson Moulin; Paulo Neves. São Paulo: Companhia das Letras, 1996. p. 7-17.

LÉVI-STRAUSS, C. Tristes trópicos. Tradução: Rosa Freire d'Aguiar. São Paulo: Companhia das Letras, 1996.

LIMA, A. A. S. O fenômeno da retenção escolar e a motivação na concepção dos discentes dos cursos técnicos integrados ao ensino médio dos campi Amajari e Boa Vista Zona Oeste - Instituto Federal de Roraima. 2018. Dissertação (Mestrado em Educação Agrícola) - Universidade Federal Rural do Rio de Janeiro, Seropédica, 2018 .

LIMA, A. C. S. Mapeamento social dos indígenas de Boa Vista (RR). In: LIMA, C. L.; CIRINO, C. A. M. (eds.). Moradores da Maloca Grande: reflexões sobre os indígenas no contexto urbano. Boa Vista: Editora da UFRR, 2016. p. 19-42.

LIMA, L. C. A valorização das culturas musicais indígenas e a formação de professores para o ensino de música no estado de Roraima. 2018. Dissertação (Mestrado em Educação Agrícola) - Universidade Federal Rural do Rio de Janeiro, Seropédica, 2018.

LIMA, C. L.; CIRINO, C. A. M. (eds.). Moradores da Maloca Grande: reflexões sobre os indígenas no contexto urbano. Boa Vista: Editora da UFRR, 2016.

LISBOA, J. F. K. Acadêmicos indígenas em Roraima e a construção da interculturalidade indígena na universidade: entre a formação e a transformação. 2017. Tese (Doutorado em Antropologia Social) - Universidade de Brasília, Brasília, 2017a. 316 p.

Etnodesenvolvimento em questão nas terras indígenas de Roraima. Abya-Yala: Revista sobre Acesso à Justiça e Direitos nas Américas, Brasília, v. 1, n. 1, p. 266280, 2017b.

LOBO, L. F. Planejamento pedagógico interdisciplinar na educação profissional técnica do Instituto Federal de Educação, Ciências e Tecnologia de Roraima - Câmpus Amajari: concepções, desafios e perspectivas. 2018. Dissertação (Mestrado em Educação Agrícola) - Universidade Federal Rural do Rio de Janeiro, Seropédica, 2018.

LOPES, M. S. Evasão e fracasso de alunos em comunidades indígenas do Instituto Federal de Roraima / Câmpus Amajari: um estudo de caso. 2017. Dissertação (Mestrado em Educação) - Universidade Federal de Juiz de Fora, Juiz de Fora, 2017. $115 \mathrm{p}$.

LOPES, T. S. A educação profissional ofertada pelo IFRR para as comunidades indígenas do município de Amajari-RR. 2015. Dissertação (Mestrado em Sociedade e Cultura na Amazônia) - Universidade Federal do Amazonas, Manaus, 2015. 94 p. 
LUCIANO, G. J. dos S. O índio brasileiro: o que você precisa saber sobre os povos indígenas no Brasil de hoje. Brasília: Ministério da Educação, 2006.

Educação para manejo e domesticação do mundo: entre a escola ideal e a escola real, os dilemas da educação escolar indígena no Alto Rio Negro. 2011. Tese (Doutorado em Antropologia) - Universidade de Brasília, Brasília, 2011. 368 p.

Educação escolar indígena no século XXI: encantos e desencantos. Rio de Janeiro: Mórula / Laced, 2019. 296 p.

MACHADO, M. F. R. Índio na cidade é índio?: considerações sobre um debate provocante. In: Anais da 26a Reunião Brasileira de Antropologia. Associação Brasileira de Antropologia. Porto Seguro, 2008.

MAHER, T. M. Já que é preciso falar com os doutores de Brasília...: subsídios para um curso de português oral em contexto indígena. 1990. Dissertação (Mestrado em Linguística) - Universidade Estadual de Campinas, Campinas, 1990. 129 p.

MANFRÓI, J. O papel da escola no contexto atual dos Kaiowá/Guarani da Aldeia Te’y Kuê de Caarapó: um estudo a partir de lideranças e professores indígenas. 2002. Tese (Doutorado em Educação) - Universidade Estadual Paulista, Marília, 2002. 219 f.

MARGULIS, M.; URRESTI, M. Juventud es más que una palabra: ensayos sobre cultura y juventud. Buenos Aires: Biblos, 1996.

MARTINS FILHO, J. V. “A língua que eu emprestei”: variações do PB entre os Macuxi. 2015. Dissertação (Mestrado em Língua Portuguesa) - Universidade Federal de Roraima, Boa Vista, 2015. 101 p.

MATOS, M. B. As culturas indígenas e a gestão das escolas da comunidade GuaribaRR: uma etnografia. 2013. Tese (Doutorado em Educação) - Universidade do Vale do Rio dos Sinos (Unisinos), São Leopoldo, 2013. 268 p.

MELUCCI, A. Juventude, tempo e movimentos sociais. In: BRASIL. Juventude e contemporaneidade. Brasília: UNESCO / MEC / ANPED, 2007. Col. Educação para Todos. p. 29-45.

MELO, J. G. Identidades fluídas: ser e perceber-se como Baré (Aruak) na Manaus contemporânea. 2009. Tese (Doutorado em Antropologia Social) - Instituto de Ciências Sociais, Universidade de Brasília, Brasília, 2009. 225 p.

MELO, L. M. Fluxos culturais e os povos da cidade: entre os Macuxi e Wapichana de Boa Vista, Roraima. 2012. Dissertação (Mestrado) - Programa de Mestrado Profissional em Preservação do Patrimônio, Instituto do Patrimônio Histórico e Artístico Nacional, Rio de Janeiro, 2012. 156 p.

Povos indígenas na cidade de Boa Vista: estratégias identitárias e demandas políticas em contexto urbano. 2018. Tese (Doutorado em Antropologia Social). Universidade Federal do Pará, Belém, 2018. 220 p.

MICHELIN, R. L.; MARTINS FILHO, A. R. A percepção dos moradores da Vila do Tepequém em Amajari-RR acerca dos impactos gerados pelas atividades turísticas. In: 
JÚNIOR, S. S. T.; MOURÃO, G. M. N. (orgs.). Amajari: um olhar geográfico. Boa Vista: Editora da UFRR, 2015. 283 p.

MIGNOLO, W. D. A colonialidade está longe de ter sido superada, logo, a descolonialidade deve prosseguir. Masp Afterall. São Paulo: Centro de Pesquisa Afterall / Museu de Arte de São Paulo, 2019, 15 p. Disponível em: https://masp.org.br/uploads/temp/tempYC7DF1wWu9O9TNKezCD2.pdf. Acesso em: 16 ago. 2020.

MOTA, L. T. (org.). As cidades e os povos indígenas: mitologias e visões. Maringá: Eduem, 2000 .

MOURÃO, G. M. N.; NASCIMENTO, S. N. Amajari, Roraima: homem e natureza. In: JÚNIOR, S. S. T.; MOURÃO, G. M. N. (orgs.). Amajari: um olhar geográfico. Boa Vista: Editora da UFRR, 2015.

NAKASHIMA, E. Y. Reatando as pontas da rama: a inserção dos alunos da etnia indígena Pankararu em uma escola pública na cidade de São Paulo. 2009. Dissertação (Mestrado em Educação) - Universidade de São Paulo, 2009.

NASCIMENTO, R. N. F. Educação escolar e identidades culturais: analisando o processo de construção de identidades a partir das práticas discursivas no contex to educacional. In: LIMA, C. L.; CIRINO, C. A. M. (eds.). Moradores da Maloca Grande: reflexões sobre os indígenas no contexto urbano. Boa Vista: Editora da UFRR, 2016. p. 177-196.

NETO, A. S. de A.; LOURENÇO, E. Direitos humanos e cultura escolar. In: NETO, A. S. de A.; SIQUEIRA, L. S. (orgs.). Direitos humanos e cultura escolar. São Paulo: Alameda, 2017. 190 p.

NETO, R.C.S; SENHORAS, E. M. Dinâmica socioespacial da Vila Três Corações no município de Amajari - RR In JÚNIOR, Stélio S. T; MOURÃO, Gersa M.N.(orgs) Amajari: um olhar geográfico. Boa Vista: Editora da UFRR, 2015. 283 p.

NOSELLA, P. Ensino médio: unitário ou multiforme? Revista Brasileira de Educação, Rio de Janeiro, v. 20, n. 60, jan./mar. 2015.

NOVAES, R. Jovens como sujeitos de direitos e as políticas públicas no Brasil. In: MONTECHIARE, R.; MEDINA, G. (orgs.). Juventude e educação: identidades e diretos. São Paulo: Flacso, 2019. p. 7-18.

NUNES, E. S. Aldeias urbanas ou cidades indígenas? Espaço Ameríndio, Porto Alegre, v. 4, n. 1, p. 9-30, jan./jun. 2010.

OLIVEIRA, A. A difícil apreensão do conceito de cultura no ensino médio. In: Reunião de Antropologia do Mercosul, IX, Curitiba, 2011.

A monocultura étnico-racial e a ecologia das cores: olhares pós-coloniais sobre a escola. Educação e Linguagem, v. 17, n. 1, p. 88-104, jan./jun., 2014.

OLIVEIRA, J. F. Gestão pedagógica e interculturalidade: estudo de caso do Instituto Federal de Roraima, Câmpus Amajari. Boa Vista: Editora da UFRR, 2019.

OLIVEIRA, M. A. Diversidade cultural no ambiente escolar: a questão indígena no Câmpus Amajari - IFRR. Dossiê Desigualdade, Violência e Relações de Poder na História. 
Mandurisawa - Revista Eletrônica Discente do Curso de História da

Universidade Federal do Amazonas. Manaus, v. 3, n. 1, p. 98-109, 2019.

. Educação escolar em alternância: a experiência dos Macuxi em Roraima. In:

APURINÃ, K. K.; SCANDOLA, E. M. R. (orgs.). Povos indígenas no Brasil: direitos, politicas sociais e resistências. Porto Alegre: Nova Práxis Editorial, 2020. p. 183-204.

OLIVEIRA, M. A.; LIMA, L.C. Estudantes indígenas e não indígenas: práticas de interação cultural em Amajari-RR. In: SANTOS, P.; MULICO, L. V. (orgs.). Educação e Direitos Humanos na rede federal de educação profissional e tecnológica. João Pessoa: IFPB, 2019. p. 295-344.

OLIVEIRA, N. A. de. Ser xavante, morar e estudar na cidade: os Xavante em Nova Xavantina/MT. Patrimônio e Memória, Unesp, v. 10, n. 2, p. 235-253, jul.-dez. 2014.

OLIVEIRA, R. G. de (org.). Projeto Kuwai kîrî: a experiência dos índios urbanos de Boa Vista - Roraima. Boa Vista: Editora da UFRR, 2010. 71 p.

PAIS, J. M. Lazeres e sociabilidades juvenis: um ensaio de análise etnográfica. Análise Social, Lisboa, v. 25, n. 108-109, p. 591- 644, 1990.

PALADINO, M. Educação escolar indígena no Brasil contemporâneo: entre a "revitalização cultural" e a "desintegração do modo de ser tradicional". 2001. Dissertação (Mestrado em Antropologia Social) - Museu Nacional, Universidade Federal do Rio de Janeiro, Rio de Janeiro, 2001.

. Estudar e experimentar na cidade: trajetórias sociais, escolarização e experiência urbana entre "Jovens" indígenas ticuna, Amazonas. 2006. Tese (Doutorado em Antropologia Social) - Museu Nacional, Universidade Federal do Rio de Janeiro, Rio de Janeiro, 2006.

PERALVA, A. T. O jovem como modelo cultural. In: BRASIL. Juventude e contemporaneidade. Brasília: UNESCO / MEC / ANPED, 2007. Col. Educação para Todos. p. 13-27.

PERES, L. Cantos e danças indígenas: a ressignificação do conhecimento tradicional da comunidade Boca da Mata no processo das transformações contemporâneas. 2013. Dissertação (Mestrado em Sociedade e Cultura na Amazônia) - Universidade Federal do Amazonas, Manaus, 2013. $129 \mathrm{f}$.

PEREZ, I. U. Uso dos recursos naturais vegetais na comunidade Indígena Araçá, Roraima - Boa Vista. 2010. Dissertação (Mestrado em Recursos Naturais) Universidade Federal de Roraima, Boa Vista, 2010. 92 f.

PONTE, K. F. Repensando o conceito do rural. Revista Nera, Presidente Prudente, ano 4, n. 7, p. 30-42, jan./jul. 2004.

RAMOS, L. da S. A mulher indígena no processo de formação social e cultural e a construção de propostas curriculares para a escola na comunidade indígena Araçá da Serra / T. I. Raposa Serra do Sol. 2013. Dissertação (Mestrado) Universidade Federal do Amazonas, Manaus, 2013. 120 p. 
RAMOS, M. Concepção do ensino médio integrado. [S. 1.]: [s. n.], 2008. Disponível em: http://forumeja.org.br/go/sites/forumeja.org.br.go/files/concepcao_do_ensino_medio_i ntegrado5.pdf. Acesso em: 12 ago. 2020.

Ensino médio integrado: lutas históricas e resistências em tempos de regressão. In: ARAÚJO, A. C.; SILVA, C. N. Ensino médio integrado no Brasil: fundamentos, práticas e desafios. Brasília: UFB, 2017. p. 20-43.

RAMOS SOUZA, J. E. A contribuição do IFAM - Campus São Gabriel da Cachoeira para o desenvolvimento local/regional frente à diversidade étnica e cultural da região do Alto Rio Negro no Amazonas (2007 - 2014). Tese (Doutorado em Educação) - Universidade Federal do Amazonas, Manaus, 2018. 337 p.

REGATTIERI, M.; CASTRO, J. M. Ensino médio e a educação profissional: desafios da integração. Brasília: Unesco, 2009.

REIS JR., R. de L. Os limites da experiência de estado desenvolvimentista no Brasil (2003-2015): o caso dos Institutos Federais. 2017. Tese (Doutorado em Educação). Universidade de Brasília, Brasília, 2017. 266 p.

REPETTO, M. Diagnóstico da demanda e da oferta de ensino médio para os povos indígenas no estado de Roraima. SECAD / MEC / UNESCO, 2006.

O ensino médio e o debate sobre uma proposta de educação cidadã intercultural. In: CARVALHO, F. A.; FONSECA, I. M.; REPETTO, M. Educação, cidadania e interculturalidade no contexto da escola indígena de Roraima. Boa Vista: Editora Fondo Editorial Brasil / UFRR, 2007. p. 42-49.

. A educação escolar indígena em Roraima: o processo histórico e as demandas atuais por ensino médio. In: OLIVEIRA, R. da S. Roraima em foco: pesquisa e apontamentos recentes. Boa Vista: UFRR, 2008a. p. 27-51.

. Movimentos indígenas e conflitos territoriais no estado de Roraima. Boa Vista: Editora da UFRR, 2008b. 193 p.

. Educación escolar indígena en Roraima, Amazonas brasileño: del conflicto intercultural a la construcción de propuestas educativas. revista_isees, n. 10, p. 131155, enero-jun. 2012a.

. Os sentidos das Fronteiras na transdisciplinaridade e na interculturalidade. TexTos\&DebaTes, Boa Vista, n. 22, p. 13-30, jul./dez. 2012 b.

REZENDE, G. C. A relação entre indígenas e não-indígenas em escolas urbanas: um estudo de caso na cidade de Campinápolis. Dissertação (Mestrado em Educação) Instituto de Educação, Universidade Federal de Mato Grosso, Cuiabá, 2003. 121p.

RIBEIRO. G. F. Criadores de gado: experiência dos Macuxi com o gado bovino. 2018. Dissertação (Mestrado em Antropologia) - Universidade Federal de Roraima, Boa Vista, 2018. 105 p.

RODRIGUES, P. C. 2016. Nem indígena nem "branco": o dilema jurídico dos indígenas na cidade. In: LIMA, C. L.; CIRINO, C. A. M. (eds.). Moradores da Maloca Grande: 
reflexões sobre os indígenas no contexto urbano. Boa Vista: Editora da UFRR, 2016. p. 133-160.

SANTILLI, P. Os Macuxi: história e política no século XX. Dissertação (Mestrado em Ciências Sociais) - Instituto de Filosofia e Ciências Humanas, Universidade Estadual de Campinas, Campinas, 1989. 162 p.

As fronteiras da República: história e política entre os Macuxi no vale do rio Branco. São Paulo: NHII / USP / Fapesp, 1994.

Pemongon Patá: território Macuxi, rotas de conflito. São Paulo: Editora da Unesp, 2001. 225 p.

SANTOS, D. S.; NADALETTI, C. L. O ensino médio integrado: avanços e desafios. In: ARAÚJO, A. C.; SILVA, C. N. Ensino médio integrado no Brasil: fundamentos, práticas e desafios. Brasília: IFB, 2017. p. 90-105.

SANTOS, R. M. R. Reflexões de lideranças Macuxi e Wapichana sobre as contribuições das TICs para os projetos indígenas locais. Tese (Doutorado em Ciências Sociais) Universidade do Vale do Rio dos Sinos (Unisinos), 2016. 226 p.

SANTOS, R. M. R; GODOY, M. G. G. O Centro Indígena de Formação e Cultura da Raposa Serra do Sol: da evangelização à formação de lideranças. Pesquisa em Debate, ed. 9, v. 5, n. 2, jul./dez. 2008. p. 1-26. Disponível em:

http://pesquisaemdebate.net/docs/pesquisaEmDebate_9/artigo_8.pdf. Acesso em: 25 mar. 2019.

- A proposta de educação profissional integrada ao ensino médio indígena do Centro Indígena de Formação e Cultura Raposa Serra do Sol. Tellus, Campo Grande, ano 11, n. 20, p. 215-239, jan./jun. 2011.

SANTOS, S. C. dos. Educação e sociedades tribais. Porto Alegre: Movimento, 1975.

SANTOS, V. S. dos; SECCHI, D. Estudantes indígenas em escolas urbanas de Rondônia: da omissão das políticas públicas à omissão do pertencimento étnico. Revista Reflexão e Ação, Santa Cruz do Sul, v. 21, n. esp., p. 52-75, jan./jun. 2013. Disponível em: http://online.unisc.br/seer/index.php/reflex. Acesso em: 07 out. 2019.

SAVIANI, D. (2007). Trabalho e educação: fundamentos ontológicos e históricos. Revista Brasileira de Educação, v. 12, n. 34, p. 152-180, jan./abr. 2007.

SEPLAN. Informações socioeconômicas do município de Amajari - RR. Boa Vista: Secretaria de Estado do Planejamento e Desenvolvimento de Roraima, 2010.

SILVA, A. L. da; GRUPIONI, L. D. B. (orgs.). A temática indígena na escola: novos subsídios para professores de $1^{\circ}$ e $2^{\circ}$ graus. Brasília: Ministério da Educação, 1995.

SILVA, D. A.; LEITE, J. F.; FEIJÓ, G. V.; FERREIRA, M. R. Reflexões sobre a implantação do curso técnico integrado ao ensino médio no IFB. In: ARAÚJO, A. C.; SILVA, C. N. Ensino médio integrado no Brasil: fundamentos, práticas e desafios. Brasília: IFB, 2017. p. 479-497. 
SILVA, D. S. A. M. Estudos metodológicos para atendimento da comunidade indígena do Araçá, com educação profissional pelo Câmpus Amajari. 2012. Dissertação (Mestrado em Educação Agrícola) - Universidade Federal Rural do Rio de Janeiro, Seropédica, 2012. $83 \mathrm{f}$.

SILVA, M. R.. Projetos de reformulação do ensino médio e inter-relações com a educação profissional: (im)possibilidades do ensino médio integrado. In: ARAÚJO, C. A.; SILVA, C. N. Ensino médio integrado no Brasil: fundamentos, práticas e desafios. Brasília: IFB, 2017.

SILVA, R. H. D. da. A autonomia como valor na articulação de possibilidades: um estudo do movimento dos professores indígenas do Amazonas, Roraima e Acre, a partir dos seus Encontros anuais. 1997. Tese (Doutorado em Educação) - Faculdade de Educação, Universidade de São Paulo, São Paulo, 1997.

. Professores indígenas da Amazônia realizam XII Encontro Anual. Jornal Porantim, Brasília, v. 218, p. 13-13, 7 maio 1999.

SILVA, T. T. Currículo e identidade social: territórios contestados. In: SILVA, T. T. (org.). Alienígenas na sala de aula: uma introdução aos estudos culturais em educação. Petrópolis: Vozes, 1995. p. 190-207.

. A produção social da identidade e da diferença. In: SILVA, T. T. (org.). Identidade e diferença: a perspectiva dos estudos culturais. Petrópolis: Vozes, 2000. p. $73-102$

SILVA LIMA, J. A. Políticas públicas no campo da educação indígena no estado de Roraima. Boa Vista: Editora da UFRR, 2017. 202 p.

SORATTO, M. A construção do sentido da escola para os estudantes indígenas do ensino médio da Reserva Francisco Horta Barbosa - Dourados/MS. 2007. Dissertação (Mestrado) - Universidade Católica Dom Bosco, Campo Grande, 2007. 132 p.

SOUSA, C. N. I. de. Aprendendo a viver junto: reflexões sobre a experiência escolar KayapóGorotire. In: SILVA, A. L. da; FERREIRA, M. K. L. (orgs.). Antropologia, História e Educação: a questão indígena e a escola. São Paulo: Global, 2001. p. 238-274.

SOUZA, A. H. C. et al. Subjetividades indígenas Macuxi e Wapichana nos deslocamentos transfronteiriços para a cidade de Boa Vista, Roraima, Brasil. Revista Espacios, v. 38, n. 8, 2017. Disponível em: https://www.revistaespacios.com/a17v38n08/17380818.html. Acesso em: 21 mar. 2020.

SOUZA, F. S. A formação continuada e sua interface na atuação docente no Instituto Federeal de Roraima, Câmpus Amajari. 2018. Dissertação (Mestrado em Educação Agrícola) - Universidade Federal Rural do Rio de Janeiro, Seropédica, 2018. 75 f.

SOUZA, I. M. M.. Interdisciplinaridade e práticas pedagógicas: reflexões sobre o curso técnico em Agricultura integrado ao ensino médio do Câmpus Amajari do Instituto Federal de Roraima. 2013. Dissertação (Mestrado em Educação Agrícola) Universidade Federal Rural do Rio de Janeiro, Seropédica, 2013. 89 p. 
SPINK, P. K. O pesquisador conversador no cotidiano. Psicologia \& Sociedade, Porto Alegre, v. 20, n. spe., p. 70-77, 2008.

TARDE, G. As leis da imitação. Lisboa: Red, 2000.

TASSINARI, A. M. I. Da civilização à tradição: os projetos de escola entre os índios do Uaçá. XXI Encontro Anual da Anpocs. Caxambu. 1997.

. Escola indígena: novos horizontes teóricos, novas fronteiras de educação. In: SILVA, A. L. da; FERREIRA, M. K. L. (orgs.). Antropologia, História e Educação: a questão indígena e a escola. São Paulo: Global, 2001. p. 44-70.

TAUKANE, D. Y. Educação escolar entre os Kurâ-Bakairi. Cuiabá, 1996. 177 p. Dissertação (Mestrado em Educação) - Universidade Federal de Mato Grosso.

TORRES, R. M. Sistema escolar y cambio educativo: repasando la agenda y los actores. Quito / Buenos Aires: Instituto Fronesis, 2003. Disponível em: https://www.oei.es/historico/ reformaseducativas/sistema_escolar_cambio_educativo_torres.pdf. Acesso em: 4 ago. 2019.

TOURAINE, A. Crítica da modernidade. Tradução: Elia Ferreira Edel. 3. ed. Petrópolis: Vozes, 1994. $431 \mathrm{p}$.

TSUPAL, N. A. Educação indígena bilíngüe, particularmente entre os Karajá e Xavante: alguns aspectos pedagógicos, considerações e sugestões. Dissertação (Mestrado em Educação) - Faculdade de Educação, Universidade de Brasília, Brasília, 1978. 173 p.

VIEIRA, J. G.; SILVA, P. S. R. Primeira Assembleia dos povos indígenas de Roraima: Surumu, janeiro de 1977. In: VIEIRA, J. G. O Rio Branco se enche de História. 2. ed. Boa Vista: EDUFRR, 2016. p. 327-342.

VOLTOLINI, Luzia. O currículo de matemática na perspectiva sociocultural: um estudo nos anos finais do ensino fundamental em escolas estaduais indígenas de Roraima. Tese (Doutorado) - Programa de Pós-Graduação em Ensino de Ciências e Matemática, Universidade Luterana do Brasil, Canoas, 2018. 412 p. 